\title{
Ecological experience in Aotearoa's deathscapes.
}

\author{
By \\ Logan \\ E. M. Drummond
}

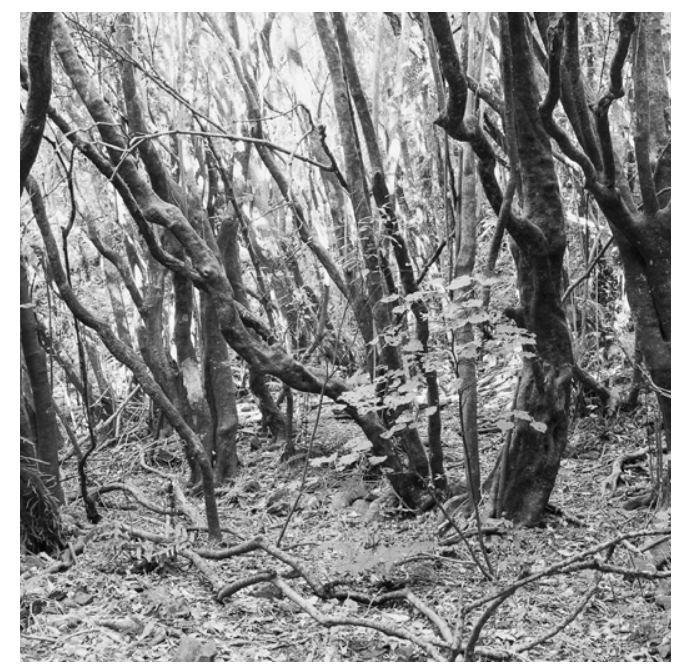

A 120-point thesis

submitted to the Victoria University of Wellington in partial fulfilment of the requirements for the degree of Master of Landscape Architecture (MLA)

Victoria University of Wellington, Te Herenga Waka

Wellington School of Architecture 


\section{Abstract}

Death is a land-use issue and therefore a landscape issue. This design-led research explores reshaping the way we experience death through our engagement with it ecologically and socially. Globally and in Aotearoa, exponential population growth and death has for burial. Aotearoa's young colonial history means the majority of our dead lie in a mono-functional, socially and ecologically vacant lawn-cemetery typology from Europe. These prevailing cemeteries hide death by sanitising the visceral qualities of landscapes above ground, whilst poisoning them below.

Karori Cemetery in Wellington will reach full capacity in less than five years, with others in New Zealand following close behind. This research will explore Te Ahumairangi in the Wellington Town Belt as the site of new forested public space cemetery. Existing landscape conditions have the potential to be interwoven with alternative burial methods that can allow for a greater frequency of burial in an urban environment constrained for burial space.

The thesis proposes that reinterpretation is needed in making Aotearoa's South Pacific deathscapes unique. The end-of-life methods of natural burial aquamation and cremation can be explored for their potential to address capacity pressures, pollutants and the negative impacts of lawnscape cemeteries on the landscape. It explores how designing the process of these burial methods in the landscape has the potential to alter experiential, ecological, social and sacred richness of death spaces.

The research sheds light on these considerations, findings and underexplored relationships, through a type of ecological-experience fieldwork to counter current practice. The uncovered range of potentials in landscapes of death can be tapped to catalyse the discipline of landscape architecture and cemetery planning into action.

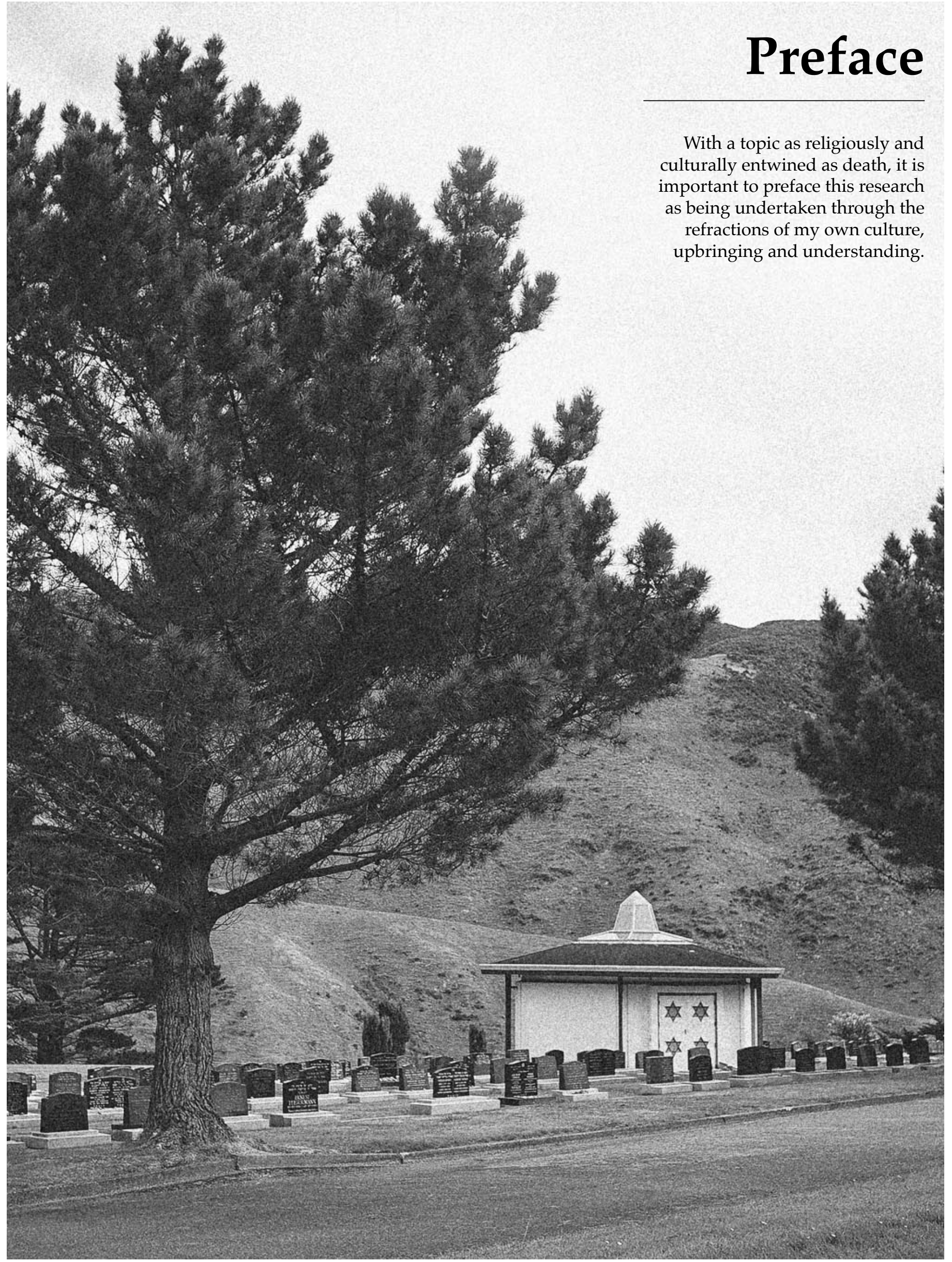




\section{Acknowledgements}

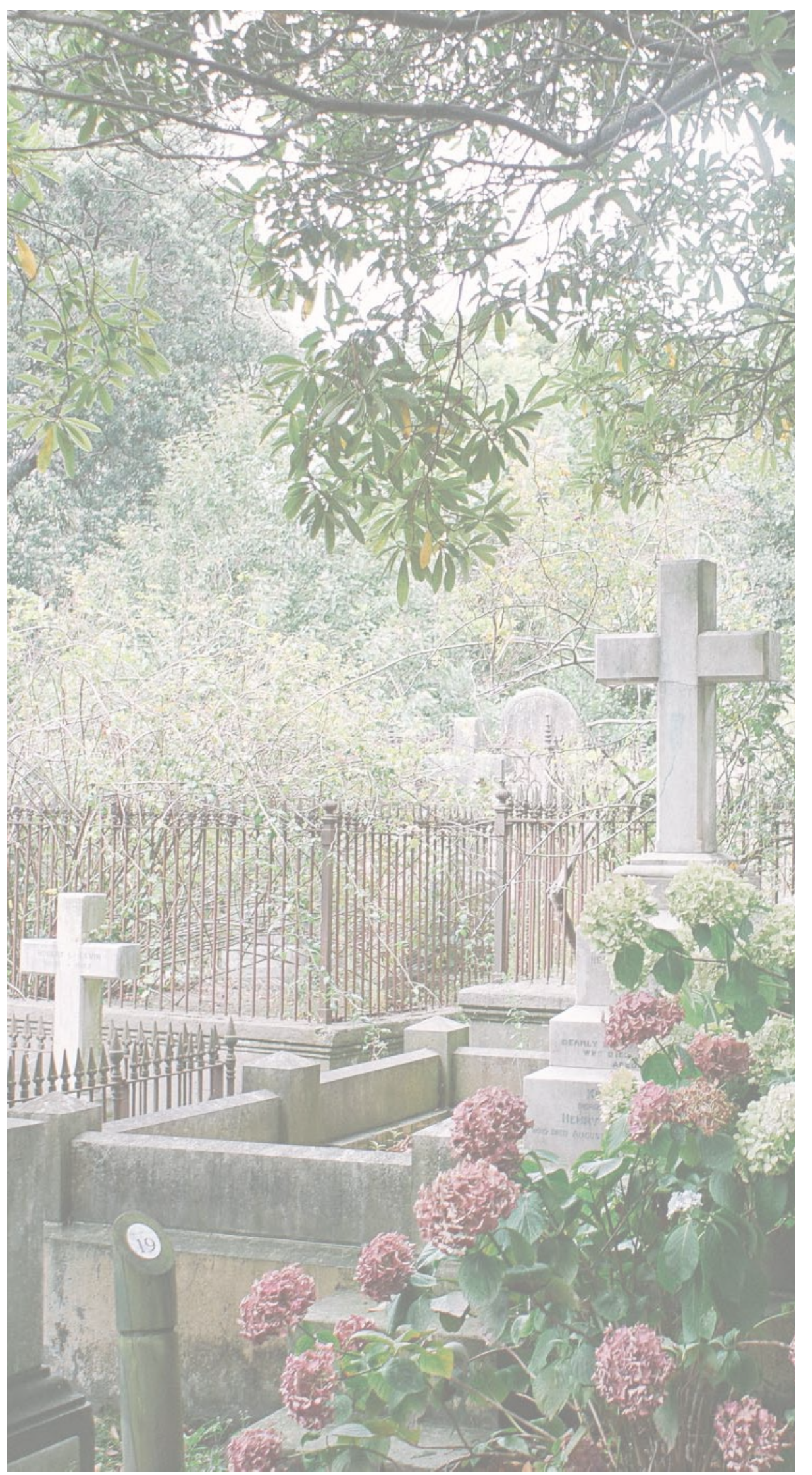

\section{Contents}

To

\section{My family}

For the unwavering support and confidence in my studies

\section{Celia}

For sharing her patience and kindness with me, each and every day.

Peter

For your trust in my ability, time and knowledge shared.

Regan

For the kind loan of equipment.

And to all the friends who have helped in different ways with the completion of this thesis.

\section{Chapter One}

Introduction

Motivation

Aims and Objectives

Methodology

Methodology Diagram

\section{Chapter Two}

Review of Thinking in Practice

\section{Chapter Three}

Māori Customs and Death in an Ecological Sense

Alternative Burial Methods

Case Studies

\section{Chapter Four}

Site Selection

Site Analysis

\section{Chapter Five}

Regional Landscapes Fieldwork

\section{Chapter Six}

Design Investigation

Forests of Death

Overall Design

Cemtery as Saviour for Potamopyrgus

Ridgeline Design

Aquatorium - Crematorium and Masterplan

Kohatu Lacusium Design

\section{Chapter Seven}

Reflection on Research Practice

Bibliography

List of Figures
Pg. 37 


\section{Chapter One - Introduction}

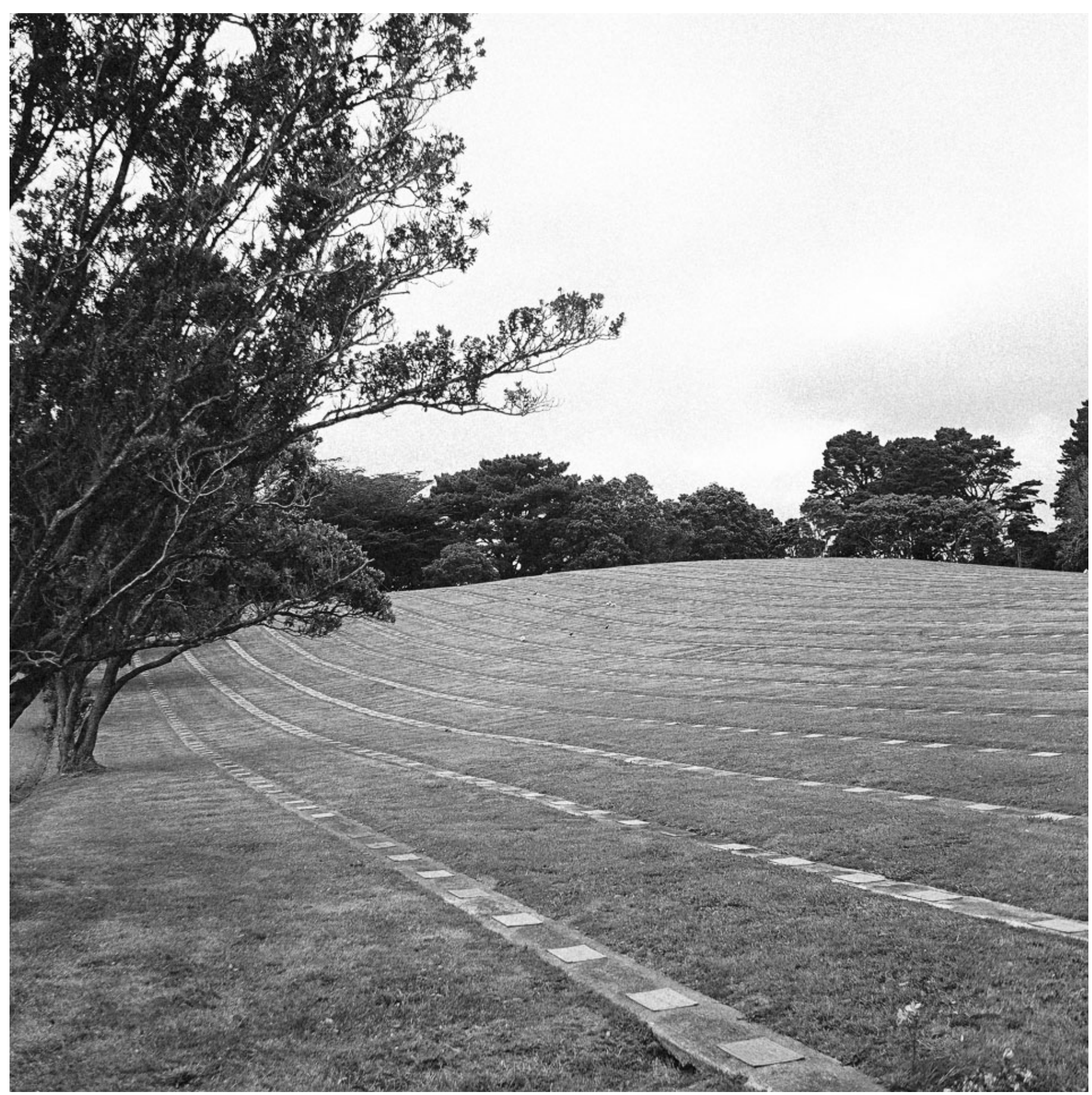

"a great, dry grass desert with uniform rows of standardized graves seem like a grim over the graves to shade them, no slopes in the landscape to lift one's no trees lean or deflect from the endless monotony of what is less a place of consolation and more like a killing field, or a sports field hastily dug up for mass burials after some terrible atrocity."

\section{Proposition}

The matter of death is one profoundly involved in the human condition, being that it is the one certain outcome for all of us. This certainty should see more importance placed on the design of spaces for the dead. This design-led research explores reshaping the way we experience death through our engagement with it ecologically and socially. Landscape architecture can bring people closer to the most human of landscapes, where the landscape is comprised of human remains. In doing so, we may approach a less rigidly perceived boundary between the binary of living person and vacant lifeless shell. An ecological perspective sees death and life as greatly intertwined, not mutually exclusive. The dominant practice of burial has separated itself from ecology and perpetuates our perceived exclusion from the cycles of decay, birth and growth.

Death is a land-use issue and therefore a landscape issue. Globally and in Aotearoa, exponential population growth has increased pressures of urbanisation on cemeteries and the lands' capacity for burial. Karori Cemetery in Wellington will reach full capacity in less than five years, with many others following close behind. This has

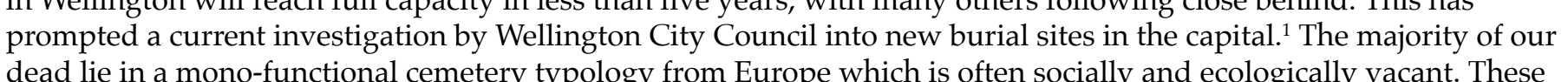
prevailing cemeteries hide death by sanitising the visceral qualities of landscapes above ground, whilst poisoning them below.

Auckland Cemeteries Manager, Catherine Moore states the current practice of cemetery siting as: "within a thirtyroutes, near a main highway; flat-gently sloping gradient; well-draining soil with minimum groundwater impact and land zoned outside of the rural-urban boundary." ${ }^{2}$ The precedence of functional and economic considerations is restrictive and precisely what landscape architecture should challenge. If we continue to push our dead out to fringe rural areas where traditionally favoured land for burial is still found, we risk further disconnecting the experience of death and our ancestors from society. These rural cemeteries eventually see modern secular urbanisation encroach around them, but by this time those buried there have largely been forgotten. Yet, spaces for the dead have a cultureforming ritual function visible in the importance of urupā in contemporary Mãori culture.

The social, ecological and experiential considerations in cemeteries should have priority over functional economics. Cemeteries founded on these considerations might become celebrated landscapes that are economically viable through their popularity. This research proposes an alternative site selection criteria for Wellington: use government owned reserves (no purchase cost, lower burial prices, most are already used for recreation); ability to accommodate alternative burial (allows for steeper and forested land); within walking distance of Central Business District (close to daily life and sociality); and a site with native afforestation aspirations (burial can fund and enhance ecology). These criteria have the potential for cemeteries to alter experience of daily life and death within the urban realm.

The thesis proposes that reinterpretation is needed in making Aotearoa's South Pacific deathscapes unique. There is no manual on the design of cemeteries and there doesn't appear to be a strong exploration in the modern world of how indigenous understandings, experiential, sacred, ecological and social aspects are engaged with in cemetery design. Fieldwork becomes important as a way to create concrete understandings of how these are produced. Endof-life methods of natural burial, aquamation and cremation have the potential to entwine these aspects together to create a richness and diversity in the ecology and sociality of cemetery landscapes. Whilst allowing for a greater frequency and space for burial in a constrained urban environment. The research will explore Te Ahumairangi in the Wellington Town Belt as the site of a new forested public space cemetery. The focus is to explore the design potentia of an inescapable phenomenon and its relationship to people in a way that will nurture the land's native ecology.

Research Question

How landscapes of burial could become re-entwined with human culture and

'Wellington City Council. "Cemeteries Management Plan Review". ecology? 
The Ephemeral Pond
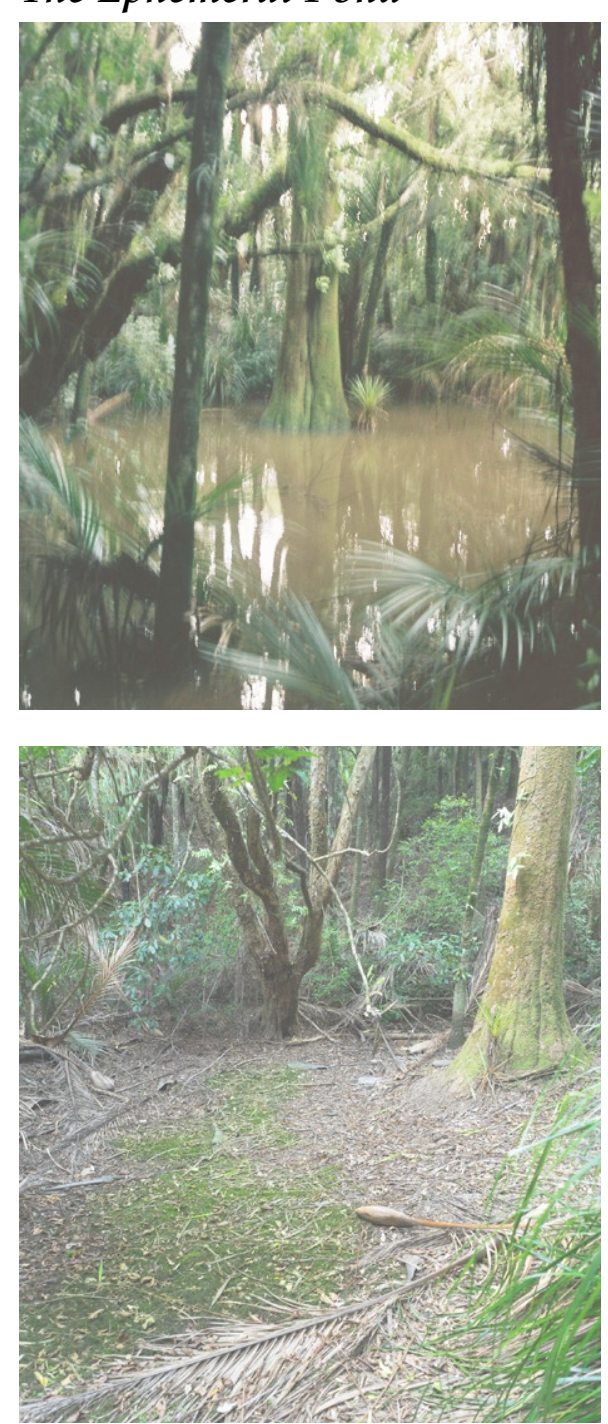

\section{Tree Ferns}

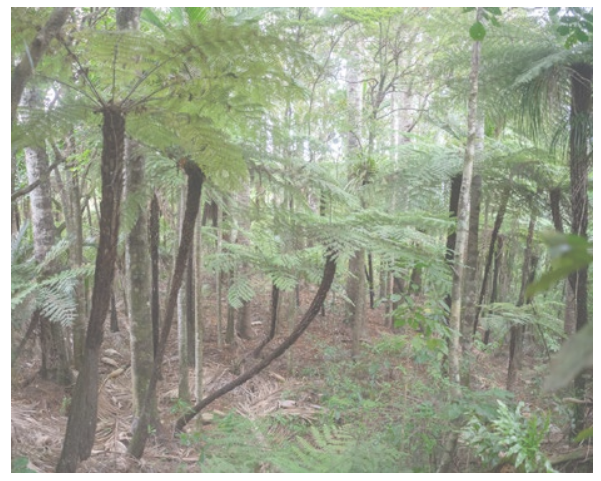

Parataniwha Gully

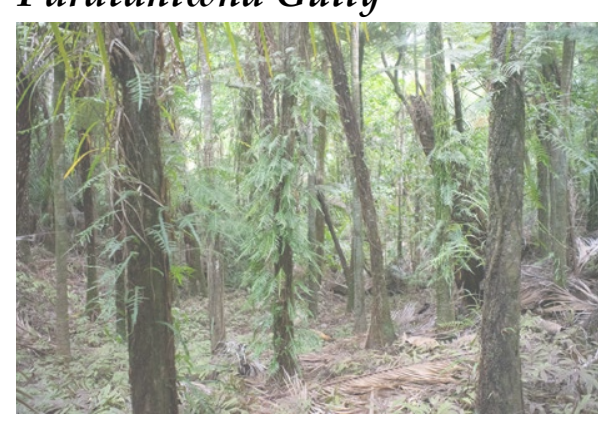

"According to tradition, karaka were "Acought by people on voyaging canoes, distrouted by people living in coastal

resource, or to identify tapu places, burial

grounds or caves."

The Parapet

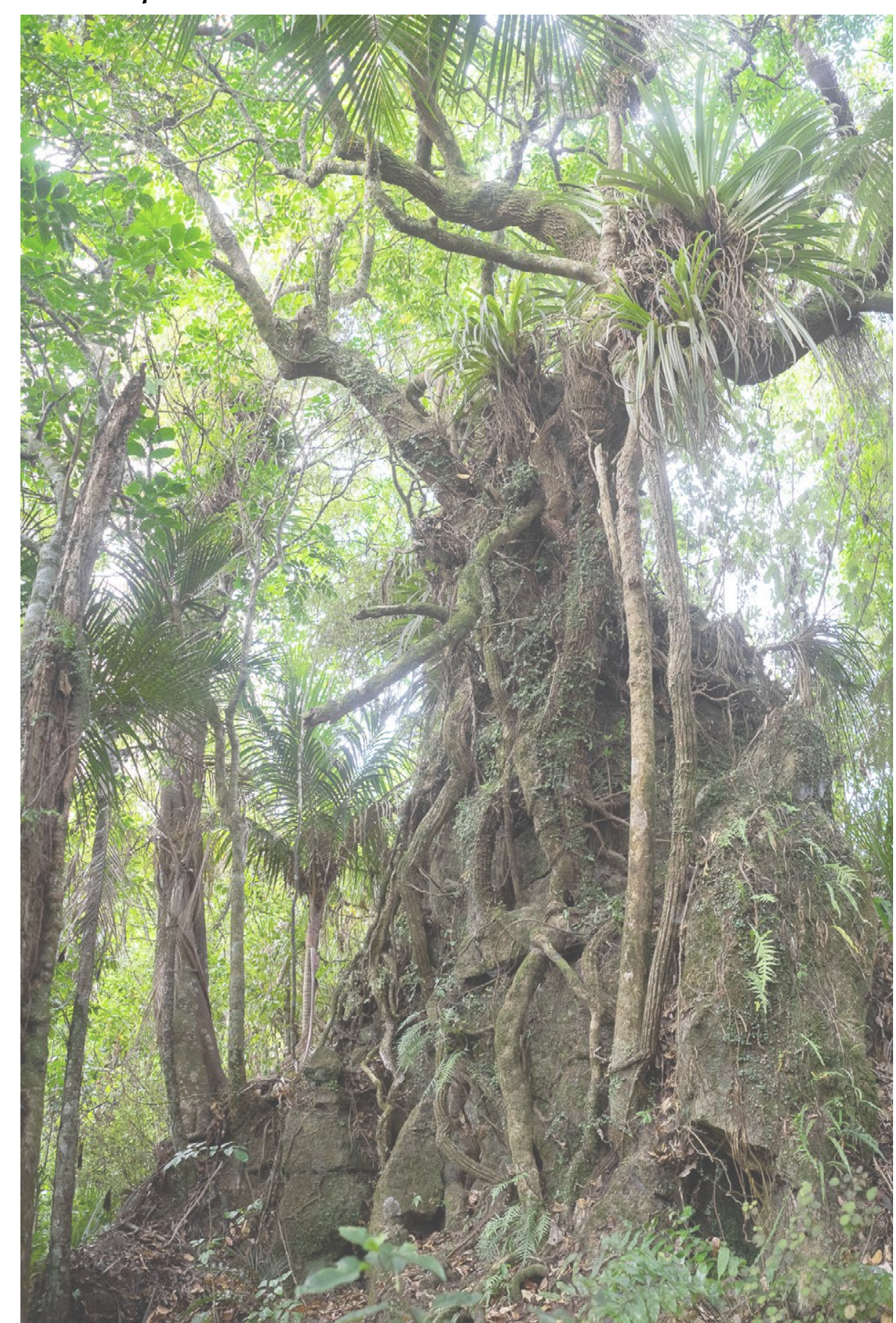

\section{Motivation}

My childhood home in the Waitākere Ranges is surrounded by a large radius of native forest reserve. This damp rainforest stretches fifteen kilometres toward the west coast through an undulating landscape marked by large dams and streams that supply Auckland with a quarte of its drinking water. I would explore this rainforest around my home, and knew most areas closer to home like the back of my hand. There was an area which managed to elude $m$ had asked if I knew about the caves mere two-hundred metres from our house. To most people it would see impossible not to have stumbled upon this earlier. But everything about the landscape keeps you away and covered in dense forest, it is not easily found. With vague directions, set out into the dense jungle.

A two-hundred year old puriri tree sits opposite our driveway, passing this down into the forest I reach an ephemeral pond which I used to play at as a child. It was summer and the hollow had dried to a patch of bright green moss. Past this, an overgrown and little used track winds down a steep ridge through tree ferns. I leave the track through a grove of kauri rickers and ponga that act as a sort of gateway. scrambling down a slippery bank I find myself in a strange high sided gully, running perpendicular to the main ridge rather than parallel. The marrow terrace cut by nephemeral stream flowing near the orizontal along it. Tall ponga, nik crambling ferns, epiphytes and

prataniwha carpet the ground. Huge puriri, karaka and kahikatea begin to dominate and darken the understory. The large karaka are uncommon in his forest and were my first sign that his area had significance. The secon was being met by intense yellow ises and the deep black pupils of a ruru in filtered daylight staring back t me. Its presence and fixation on would later become eerie. Furth long this gully, what looks like a large clay sinkhole falls two metres underground, another irregularity. A large series of jagged stones jut high above head forming the cliff below and the wall of the gully, like a castle parapet. This exposed geology is much unlike the surrounding clay nd absence of rock with which I am amiliar. These parapets have huge trees perched atop them, large aeria roots of rata and akapuka snake down to meet the ground. The small 'caves' I was looking for are revealed. Sunken in a ditch behind this parap openings or 'caves' underneath. from above, form very narrow
What I had encountered

Afterward, these strange irregularities begged research. I an old rua koiwi (resting place of populated in my mind I could imagine how the first people to discover this would have seen the potential of the landscape here to conceal and protect their dead. The old karaka trees are nga uru karaka groves planted as food sources or to mark areas of significance. The nocturnal ruru I had locked eyes with, belongs to the spirit world in the Māori worldview. Their haunting cry and watchful nature are linked with tapu, guardianship, forewarning and grief. The large clay hole is not recorded but may have been a rua (midden). The 'caves' were probably formed by excavating underneath the boulders to create small openings in which bones could be hidden. Although the bones were relocated some time $\mathrm{ago}^{5}$, for respect and secrecy of the deceased photographs and maps of the burial caves themselves are not included in this research. In tikanga Māori, a deceased person's mauri (life force) by the process of photography or replication, diminishing a person's mana.

It was here, just over a steep ridge from where I lived, that the interconnectedness of death and life in the forest began to emerge for me. I developed a fascination with forested burial grounds and began to question our current way of burial.
${ }^{4} \mathrm{Haami}$, Pütea whakairo: Māori and the written word, 33.

Hayward and Diamond, Prehistoric Archaeological Sites of the Waitākere Ranges and West Auckland. 


\section{Aims and objectives}

The research aims to design a multi-functional urban cemetery that accommodates alternative burial methods to allow for a greater capacity of burial in land constrained spaces. This public space would undergo metamorphosis with the interment of our ancestors to enrich the experiential, ecological, social and sacred richness of death spaces.

To achieve this an exploration of Māori conceptions of ecology and death could provide a framework for a uniquely South Pacific relationship to death and the landscape. An understanding of current cemetery practice and its creates the social and sacred in relation to landscape elements. The research will investigate natural burial, aquamation and cremation as processes that can nurture life and be intertwined with the landscape. Overall, the research focusses on how Aoteroa's burial landscapes can express the interconnectedness of human culture and ecology.

\section{Scope}

The research hopes to facilitate a practice for the design of Aotearoa's memorial spaces. The ambition is not to produce restrictive guidelines for awareness to potentials in by design, an experiment that aims to bring Attention is placed on making alenative burial work in the context a Te Ahumairangi, a single hill in Wellington's Town Belt. The particular landscape conditions are all singular in their combination. If a broader scope and timeframe were possible the research would investigate the potentiol of multiple smaller cemetery sites linked throughout the Town Belt The data readily available is limited for Te Ahumairangi, personal observitions and fieldwork were used to map most areas of interest such as geology hydrology human use, etc. Terrestrial LiDAR was tentatively used to aid design of forested space, large data sets and the learning curve in processing the data limited its scope to a small area within the site. It could prove to be extremely useful in forested cemetery space design.

\section{Methodology}

The methodology for this research aims to fill gaps I have observed in these and literature that focus on cemeteries. It experiments with a wide range design. An investigation into the existing often overlooked in cemetery cemeteries; historic Mēori burial and conception of ecology; alternative methods of returning the body to land; and how the body ceates experien of the social and sacred in relation to landscape elements is undertaken in a literature review.

Fieldwork is the main driver of the research and attempts to explore a range of underexplored realms in the design and existing conditions of cemeteries of un ecologies. A range of Aotera's cemeteries are explored to find potentia design strategies and drivers for burial in Te Ahumairangi. Waikumete, Karori, Makara and Bolton Street Cemetery are analysed through methods of photography mapping and section studies. These local case studies were found to be more important than remote international studies. The ability to bodily experience cemeteries and arrive at personal conclusions and discoveries of what is most interesting was invaluable.

Studies of how burial interacts with steep topography are undertaken to understand the possibilities for how currently disregarded land for cemeteries could be utilised to provide alternatives to current restrictive cemetery siting requirements. It also proposes the experience of cemeteries could be directed and intensified with topography.

Geology is mapped through personal observation and is explored for the potential it has in marking the place of the dead, how it determines suitable depths for burial and the way burial disturbs soil layers that leads to changes in floristic compositions. A study is made into how graves might be dug without the use of large machinery on Te Ahumairangi.

The entire perimeter of Te Ahumairangi's 38 hectares was walked and documented to understand accessibility, how it connects to and is perceived by the city. The interior was walked numerous times to gain knowledge of where new paths or removal of others could benefit clarity, ease of route and experience of the hill. Carparking and alternative means of access on the steep terrain are explored for the viability of a cemetery in the Town Belt.

A series of local ecology studies surrounding and including Te Ahumairangi are undertaken through drawing and photography to explore the spatiality and bodily experience of native and exotic forest species. This ecology fieldwork is used as framework for understanding what native species are absent from the regenerating site and can be reimplemented to alter the experience of Te Ahumairangi through natural burial planting, alongside those species which occur on site. Speculations are made on how an influx of nutrient from bodily decomposition might affect the growth of forest. Cultivation of native plants traditionally used for basketry and weaving are suggested for the construction of natural burial caskets, to help create a selfsustaining cemetery. Current practice only tentatively engages with forested space, due to the complexity of representing and designing growing material. Under-canopy documentation methods will be used to help represent the complexity and aid in the design of Te Ahumairangi's forested space. 


\section{Methodology:}

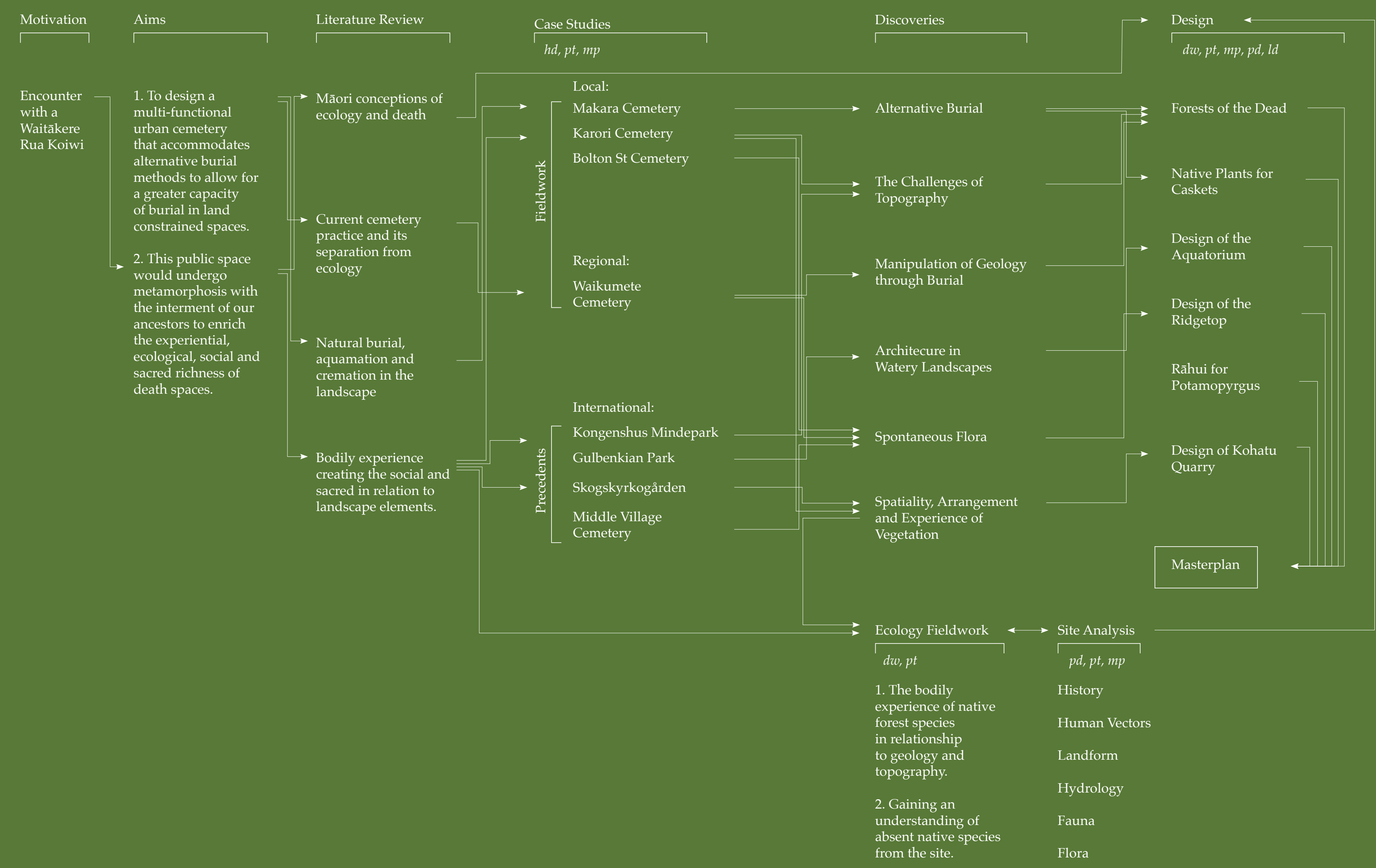

\begin{tabular}{lll}
\hline Parametric Design (pd) $\quad$ Drawing (dw) $\quad$ Photography (pt) & Mapping (mp)
\end{tabular}




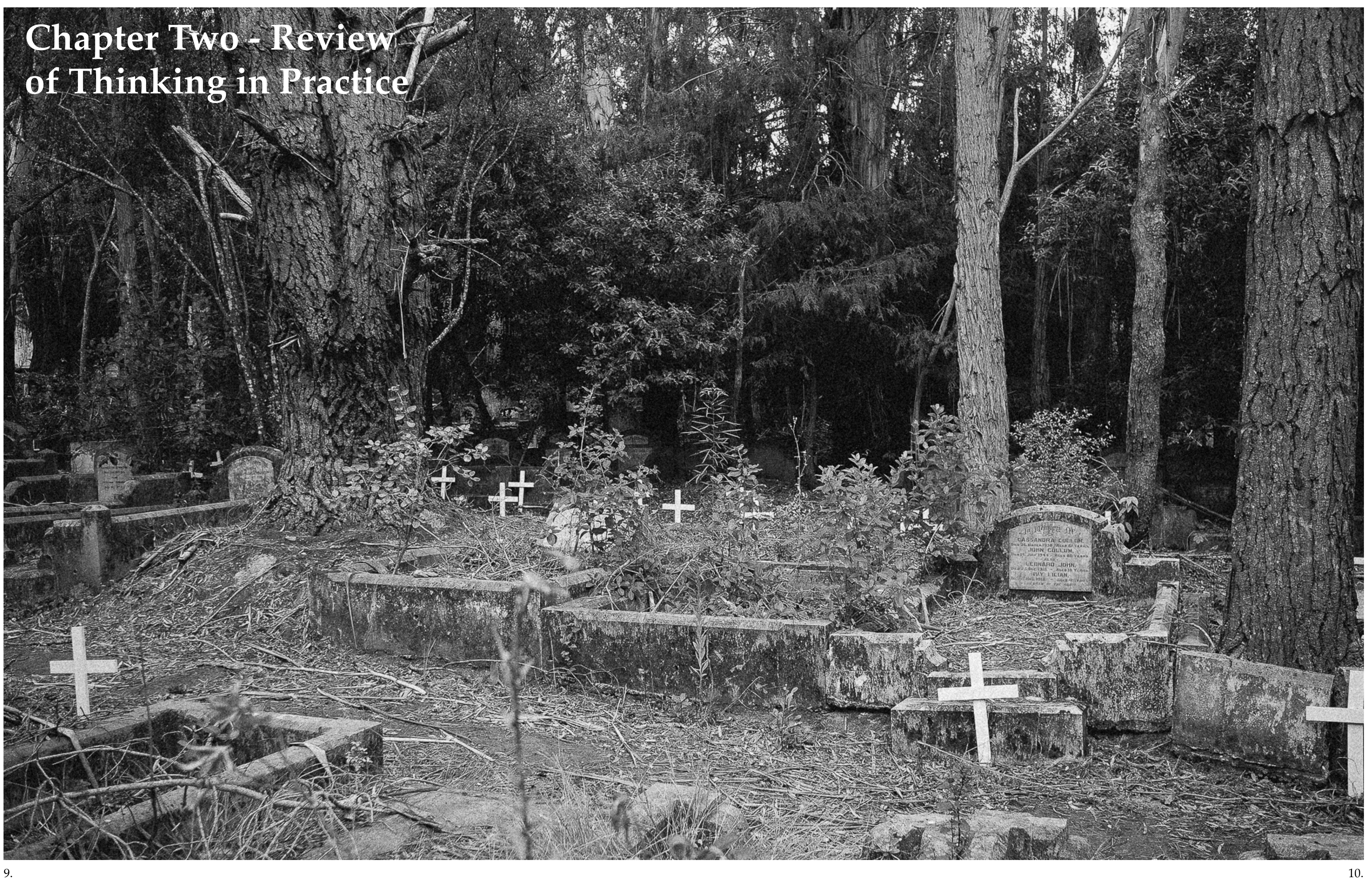


Explore Māori conceptions of ecology and death to provide a framework for a uniquely South Pacific relationship to death and the landscape.

The first Polynesian voyagers to Aotearoa brought concepts like rähui, tapu and whenua ashore. Over time they developed a relationship to land formed around nature's rhythms. European ships brought the forward ticking time of the pocket-watch and thus a change to the perception of time as cycl
rhythms of nature. The present and future still drives the 'productive' economics of European life, with a fundamental notion of 'time is money'. Māori spiritual connection to whenua became suppressed as it relied on the past and the notion of utu, that which happens in the future and past is reciprocally connected. ${ }^{6}$ For the European, the experience of those in the past appears to offer relatively little in the economy of the present, this is visible in the current neglect for the elderly and cemeteries. By contrast, the importance of urupa in contemporary Māori culture maintains the link between ancestors, descendants and the community. ${ }^{7}$ Cemeteries are potent cultural landscapes that reveal how the past produces the present, and are also where the two mingle. Utu can reimagine ways of returning to the earth, where our ancestors can contribute in passing, to the public space of the future. In turn these spaces might foster greater respect for the elderly and deceased.

Aotearoa has come to understand our native landscape as a collection of primeval life with which we have not evolved. This is a hangover from a legislated separation between culture and nature that sees people as visitors to an unpopulated, primordial land. Scenery preservation was brought under law in 1892 and helped to save Aotearoa's rapidly disappearing forest from vanishing further under a veil of grass and grazing animals. But it created two types of landscape: one in which the urge was to advance society, and the other in which the urge was to exclude it. There was no middle landscape' in which the urge was to progress people living with the land's indigenous life. ${ }^{8}$ This also removed a framework for dying with the indigenous, our cemeteries separate the dead from the natural cycles of the land's native ecology. Park suggests the Waitakere Ranges are closer to this 'middle landscape', a forested domain of human residence where the environment is intertwined with culture. A different relationship with land, a shared ecosystem. It was near my home in the Waitākere Ranges where I encountered a rua-koiwi (resting place of bones) in the dense forest. Death as part of the indigenous landscape, it provoked this research exploration into human burial and its integration with nature. But today, Aotearoa is a country that might be averse to the notion of burying the dead in our 'pristine' forests.

A shift in reading nature as disjunct boundary lines of protected objects to knowing it as a highly connected nourishing terrain that gives life and receives death. The conservation estate has purged Māori customary rights and care, making whenua - the interconnectedness of people and nature, a marginal concept. Mãori established an umbilical connection to the land by placing the placenta within it, entangled in this connection is tangata whenua (people of and from the land). The dual meaning of whenua is both land an afterbirth. Whenua appeals to ecology in its most fundamental principle, that everything is connected. The responsibility to the other life with which we share the land, flows from that interconnectedness. The linguistic roots of whenua are shared across the Pacific and early traces found in the Indian ocean. ${ }^{9}$ All are conceptualisations of identity in which the relationship betwe "All are conce and land is vital, a feedbak process from centuries of the social system experiencing the and co-evolving to the ecosystem's limits.
Modern alternative burials use trees to mark the place of the dead, early Mãori burial shares the importance of trees and uru in marking significant spaces. Kahikatea in the Mãori landscape is a symbol of birth and death. The placenta is as the land and the umbilical cord, iho is the strength of a tree

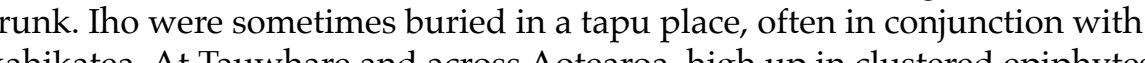
across Aotearoa, high up in clustered epiphytes in kahikatea the bones of ancestors were placed. Māori sensed that trees Christianity forcibly displaced them. ${ }^{10}$ "Every unusual place, or spectacle, whether remarkably beautiful or ghastly, imprints a touch or apprehension of wheme latent invisible power."11 Jackson accounts of indigenous Lithuanian's sacred groves and their belief that harming the trees was a sacrilegious act. To aid his rule of Lithuania, converted Catholic King Władysław II Jagiełło of Poland felled their sacred trees to example the superstition of the inhabitants. Met with no divine retribution, the indigenous people began to believe the Kings authority and Christian religion. Oddly the Polish pagan born Jagieło, grew up in a country with its own history of sacred pagan groves. The Białowieża Forest in Poland, one the largest and last remnants of ancient forest on the entire European Plain was owned and named after him, and he treasured his time in this forest. ${ }^{12}$ Lithuania is close to the furthest on Earth you can get from Aotearoa, but tapu was treated the same by early missionaries converting Māori to Christianity. At Tauwhare, this situation was echoed by missionary Cort Schnackenberg and his attempt at burning the burial kahikatea to rid Māori of their 'superstitious' fear of tapu..$^{13}$ "In some incomprehensible way (to Māori) the Pakeha seemed to be able to ignore the tapu restrictions of the Mãori atua without fear of retribution".

Our cemeteries have been removed from the interconnectedness of human culture and ecology. Utu, whenua and tapu have all had a history of suppression and erosion, yet they appear useful in reimaging a connection to landscape, death and life. What would it mean for death to become part of the forested landscape again and what would these burial grounds do for Aotearoa's way of perceiving and conceptualising death and life? A landscape which nourishes life and which we nourish, through death.

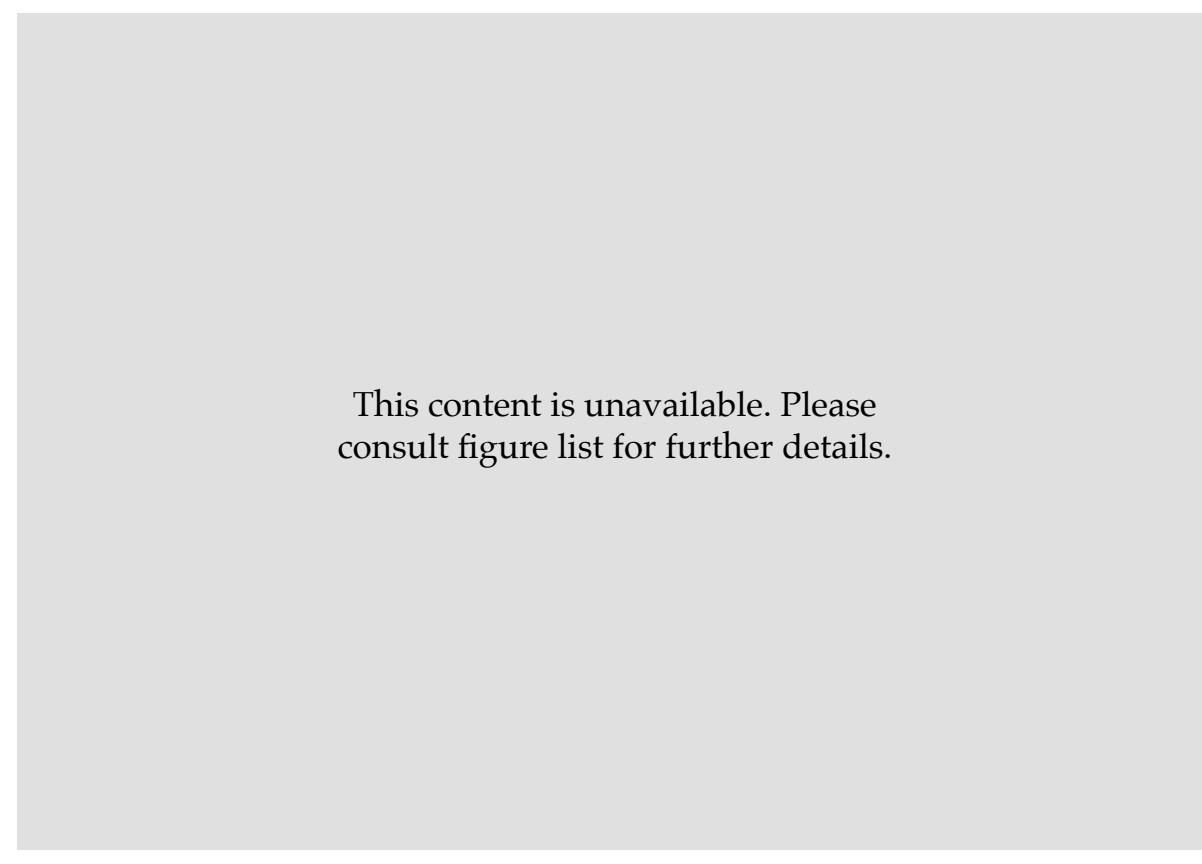

Awatere, Māori Sovereignty, 30. Deed, Unearthly Landscapes, 190 Whenua, 202.

${ }^{9}$ Park, 240.

Park, Ngā Uruora, 168-169. Jackson, 171.

"Hunt, "Dead Wood." 


\section{Current cemetery practice and its separation from ecology.}

Current cemetery practice relies on word and symbol to convey memorial and often perpetuates a range of cliches. Forest Lawn Memorial Park is often described as a funereal theme park or the Disneyland of Death. ${ }^{15}$ Historically, incentive was needed to urge a larger portion of society to visit a funerary landscape, at Forest Lawn the answer was art and sculpture. Contrary to its name, there is no forest in a natural sense, instead it is an expansive lawn and home to the largest replica collection of Michelangelo sculptures in the New World ${ }^{16}$ Aldous Huxley's literary character Jeremy Pordage accounts of his visit there:

"statues of Peter Pan and the Infant Jesus, its groups of alabaster babies playing with bronze rabbits, its lily pool and an apparatus labelled The Fountain of Rainbow Music, from which there spouted simultaneously water, coloured lights and the inescapable strains of the Perpetual Wurlitzer... Statues wherever you turned your eyes. Hundreds of them bought wholesale.. from some monumental masonry concern in Carrara or Pietrasanta. All nudes, all female, all exuberantly nubile. The sort of statues one would expect to see in the reception room of a high-class brothel in Rio de Janeiro." ${ }^{\prime 17}$

The designer of Forest Lawn, Hubert Eaton set three slogans which seem to have been adopted by the majority of cemetery designers since. They are: depict life, not death; build a safe repository for our beloved dead and a place for the living to reverently enjoy; and spend one dollar in construction today to save one cent in care tomorrow. ${ }^{18}$ The efficiency focused mind of Eaton was the first to conceive of plaques recessed below the lawn. This allowed faster maintenance by mechanical mowers and the added benefit of giving superiority to the flowing lawn and plethora of sculpture. However, in keeping with his first slogan it supressed the presence of the dead. This suppression of death and sadness is often perpetuated in cemeteries. The preoccupation with the relentless pursuit of happiness, is evident in the joyous wurlitzers, rainbow fountains and the Peter Pans of Forest Lawn. It parallels pharmaceutical remedies that are promoted as a means of escaping any emotion other than joy. Modern landscape architecture can simply become part of the drive for eternal bliss. ${ }^{19}$ Before he became manager of what would become Forest Lawn, Eaton viewed the native chapparal ecology sprouting from old graves as depressing. He dreamt of the picturesque cemetery he would design with tall trees, wide lawns and playful fountains.

"In the same way that middle class desire dreamed up suburbia, a place where everyone has their own patch of lawn to fortify their bungalows against real wilderness, carpets of sod would be unrolled and laid across the hills, smothering the chaparral in an act of botanical colonialism.."20
From an ecological point of view, this preoccupation with joy has led to vast innovation in herbaceous perennials, bulbous plants, annuals and brightly flowered species. Old varieties are preserved, new ones bred, with this process creating a profusion of options each year. However the varieties of woody plants and trees have stagnated for years and display very little development. Cemeteries and current trends of natural burial are complicit in the focus on meadows, flowers and grasses and have taken attention awit from the opportunities that forest trees and native ecosystems can provide in memorial space. Woody plants are the elements that shape the fundamental basis of spatiality and habitat in the landscape. ${ }^{21}$ Eaton's economic concerns took precedence over the ecological, sense of sacred and celebrated the joy of life by hiding death. Landscape architecture should offer an alternative focus in bringing social and ecological aspects to the forefront of cemetery design.

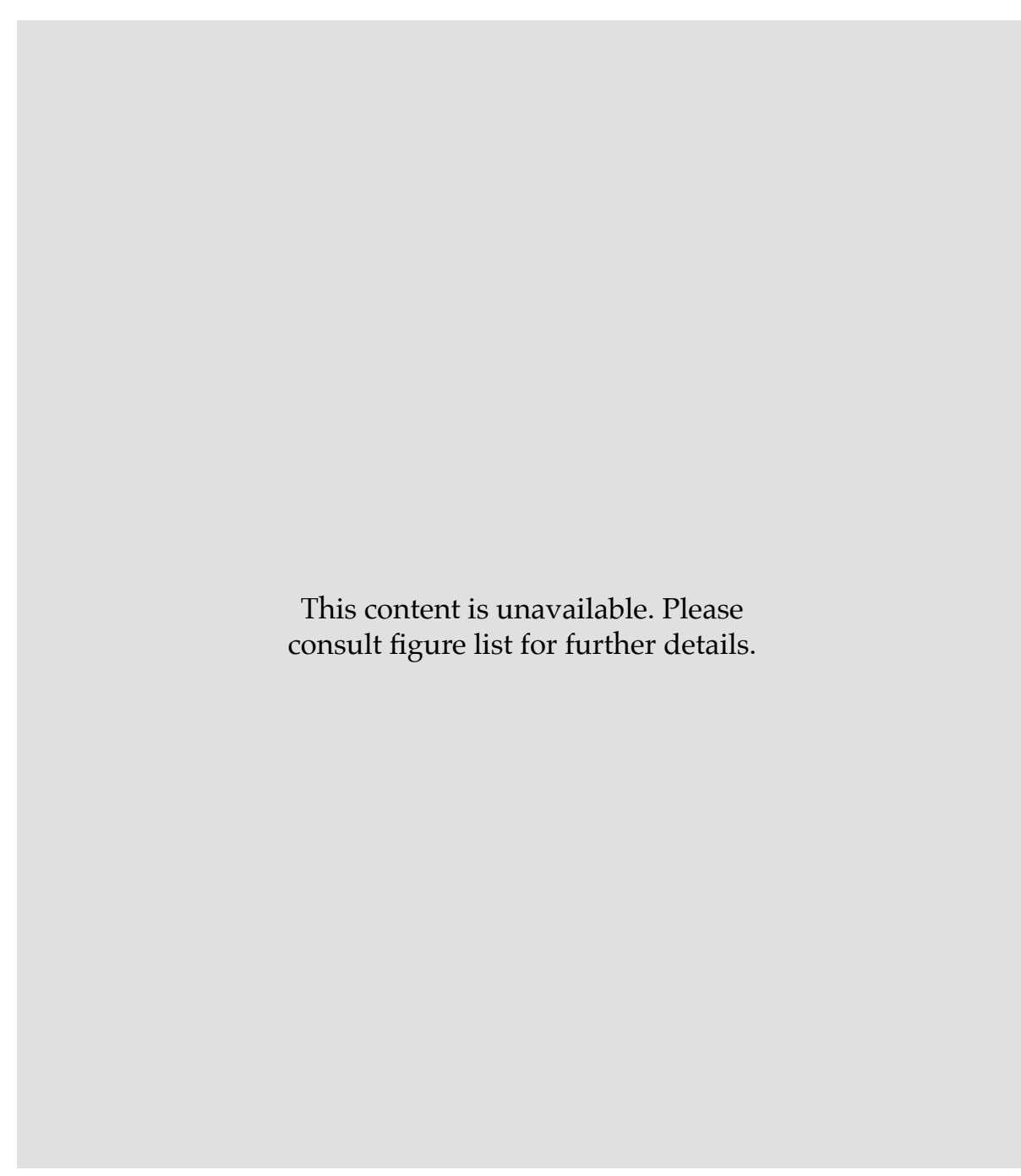

${ }^{15}$ Diakiw, "Disneyland of Death."

"Wolschke-Bulmahn, Places of Commemoration, 87.

${ }^{17}$ Huxley, After Many a Summer, 115.

${ }^{18}$ Wolschke-Bulmahn, Places of Commemoration, 87.

${ }^{19}$ Bowring, Melancholy and the Landscape, 5.

${ }^{20}$ Diakiw, "Disneyland of Death."

${ }^{21}$ Girot, Topology, 154 


\section{Decomposition}

Bodily burial has a range of polluting practices aimed at halting and supressing decay, however as decomposition is integral part of ecosystems this leads to a range of negative environmental effects. Formaldehyde used in embalming solution and coffins to slow decay, leaches out and poisons the soil; concrete vaults separate the bodies nutrients from the land; and fossil fuels for mowers and leaf-blowers are used in the maintenance of sanitised grounds. ${ }^{22}$ Embalming and burial deep underground means it takes fifty years for tissue to break down. By eighty years in a coffin, bones begin to crack and deteriorate, leaving nothing but the brittle mineral frame behind. A century in, bones will have turned to dust leaving only teeth and inorganic material. ${ }^{23}$ Graves are generally dug six-feet-under from a historic fear of reanimation and beliefs around disease and hygiene. However, no significan health risk is posed from a corpse, even above ground. ${ }^{24}$ Natural burial is a growing trend which aims to revegetate areas through burial. Instead of a memorial headstone, the experience of ecology becomes a symbolic legacy of the deceased. It requires shallow burial in the more biologically active layer of the soil, restricts the use of formaldehyde and uses natural material caskets. In the right conditions the body breaks down within a decade. Bodily decomposition with natural burial over large areas could vastly alter soil composition and available nutrients in the landscape. In Cameroon, sacred village groves are often associated with burial and many hold the skulls of royal ancestors. Botanical studies have shown that these burial activities over a long period, affect the floristic composition and appearance of these sites. They are often the result of unintentional actions or management practices that interact with the spontaneous growth of vegetation. ${ }^{25}$ Planting trees on graves could be more captivating with the experience of the living in mind, many current natural burial areas such as Makara Cemetery are revegetating first and waiting decades before the forest can be navigated by the public. This limits families and the public from experiencing the resting place of their loved ones, designing the placement and species of trees first can allow these spaces to be accessible from day one. Natural burial offers the opportunity to design a forested public space that undergoes ecological metamorphosis with the interment of our ancestors. It offers a potential to create novel ecology with which we are unfamiliar, as exampled by Cameroon forests grow differently in the context our buried ancestors.
Aquamation or alkaline hydrolysis is a way to transform organic matter into inert components. It uses water, an alkaline solution, high temperatures and pressure over the course of a few hours to produce a sterile, slightly alkaline water. The bones that remain are very brittle and can be powdered and put in an urn like cremation. Aquamation leaves a considerable volume of benign water that proves an ethical problem for its widespread adoption as a viable end of life choice. To most it seems wrong to discharge this water which seems to hold some 'essence' of the deceased into the wastewater system. Yet embalming which drains a large portion of a cadaver's blood is treated in this way. ${ }^{26}$ Another option is to irrigate land, but the mechanical and utilitarian aspect of such a system also seems to lack empathy. What might a respectful journey of liquid remains look like? The experience of aquamation invites exploration, an increase of water in the landscape might be experienced in its coolness, moisture, sound and the ecology it turns verdant through water exchange.

\section{Combustion}

Cremation is the most popular end of life choice in Aotearoa, owing to a cheaper cost and less demanding space requirements. The negative aspects of cremation include carbon-emissions, reduced air quality, and the energy required..$^{27}$ Bio-urns are a relatively new offering that are half filled with ashes and soil, that a seed or seedling is planted in. The compostable urn are buried in the landscape, through collective urn burial an individual can become part of larger memorial forest. Due to the much smaller area occupied by an urn that a body, they can be buried almost anywhere. Their size means: underlying geology is not so restrictive; they can be buried on much steeper slopes; use a fraction of the space bodily burial does; and clears less vegetation in forest burial. Bio-urns provide the potential for reforesting slopes and changing our experience of vegetation and topography in cemeteries.

This content is unavailable. Please consult figure list for further details.
${ }^{22}$ Braunius, McManus and Elliot. Death and Dying in New Zealand, 80. ${ }^{23}$ Shira and Echevarria. "What Happens To The Human Body After 100 Years Inside A Coffin".

${ }^{24}$ Fisher and Reed. "Risks Posed B Dead Bodies After Disasters".

${ }^{25}$ Woudstra and Roth, A History of Groves, 123-126.

${ }^{26}$ Braunius, McManus and Elliot. Death and Dying in New Zealand, 9495. 


\section{Bodily experience creating the social and sacred in relation to landscape} elements.

The focus on economic and utilitarian aspects in cemetery design has eroded sacredness in burial space. This functional precedence in cemeteries is

transparent to most and this visible intention alone might act in removing the experience of these cemeteries from a sense of the sacred. A modern attitude shared by emerging landscape architects rescued some cemetery landscapes from a supporting role to architecture or as decorative scenery. Landscape of the sacred no longer relied on the symbolic language of buildings.

\section{Topography and the sacred}

Kongenshus Mindepark in Demark designed by Carl Sorensen commemorates the early of efforts of farmers who reclaimed the heathland to feed the nation during the Danish resistance whilst also celebrating the heathland ecology. The design moved almost no earth, instead the experience through the memorial space. As one passes the rows of large stones, the body through past experience connects to the sacred associations stone dolmens of prehistoric burial hold in the collective memory of Danish. ${ }^{28}$ The tall slopes of heath block out the surroundings and draws experience down the valley and into the sky above.

In Serres' Five Senses, he explores the 'audible' and argues that noise is what defines the social. He suggests that of bodily senses, our perception of noise is what unites space and creates a single phenomenon perceptible to all. Pinara is an ancient burial cliff, the vertical graves are like "ten thousand dead eyes watching over the ruins of the old city on the hill below... Death keeping watch over life." ${ }^{29}$ On the other side of the city lies an old Greek theatre. The whole landscape becomes involved as an amphitheatre in which the city is the stage, amplified by the echoes of the funereal cliff-face.

"The lively city is directed at what is being broadcast in the background from a thousand shadowy mouths, tombs that blacken the tall, sombre cliff. The lingering moan of the dead still audible in the circus two thousand years after the death of the city."

Collectively, people listen to the transmissions of their dead. From the theatre it appears a spectacle of death, but as one listens, they see it is a matter of hearing, a sound stage created by the body in space and its relationship to soaring geology and the dead. Sonic vibrations resonate throughout the space, infolding the sociality of the city with death.
Vegetation and the Sacred

Skogskyrkogarden engages the individual and group through experience of the forest. The forest existed before Asplund and Lewerentz, proposed their design. The sense of place is based on the sacred significance of this pine forest and rejects the cliché of the traditionally picturesque cemetery. The dark mass of pine represents the original matrix of the place, and the designed voids reflects culture. The main processional path leads the eye toward the sky and directs human understanding toward its integration with natural and celestial realms. A sense of resurrection for the living. and distinguished the sacred and profane but was also where the two world met. Koreans understand the daily profane in terms of 'horizontal space', experience of time passing. Transcendent experiences like birth and death are related to 'vertical space' or the sacred, in which the earth is linked to the sky and humans to Heaven. These experiences of vertical space are centred on these village groves ${ }^{32}$ Ancient trees "confer a sense of continuity on the changing settlement around it". ${ }^{33}$ Trees and landscapes condense and mingle time, they are reflections of the past, are experienced in the present and suggest a future.

This content is unavailable. Pease consult figure list for further details.

Aotearoa's focus in the past century has been and remains on conservation and revegetation as a consequence of widespread deforestation. Areas are revegetated based on regional lists of suitable species or performative aspects such as nitrogen uptakes for riparian projects. While this is important, it has led to a severely underexplored realm in the experiential qualities that native forest species possess. Unlike the relatively flat and dual-layered pine forest of Skogskyrkogarden, our native forests are often dense, multi-layered and undulating temperate rainforests. In landscape design, many people negatively view our native species as a series of muted browny-green tones. Despite negativity toward New Zealand's 'colourless' appearance of flora, most experience awe in the presence of cathedral-like kauri at Waipoua or the way forest species like rimu, totara and kahikatea structure space. Trees direct human movement and experience through the height of branches, size of trunks and canopy, density of spacing, opacity, colour, roughness, scent and a range of other aspects in their space making. This cannot be understood separately from topography, geology and other components of landscapes either. The combination of these factors is underexplored, and much is desired in how Aotearora's landscape elements create differences in bodily relations and space making in any context. If gentle tonality and shifts in monochromatic flora provide restful repetition ${ }^{35}$ and our native trees are capable of structuring reverent spaces, then Aotearoa has vast potential to create incredible forested cemeteries.

${ }^{28}$ Luciani and Boschiero, Kongenshus Mindepark Mindepark: The International Carlo Scarpa Prize for Gardens, 87.

${ }^{29}$ Serres, Sankey, and Cowley, The Five Senses: A Philosophy of Mingled Bodies, 108-109.

${ }^{5}$ Serres, Sankey, and Cowley, 110.

Wolschke-Bulmahn, Places of Commemoration, 102.

${ }^{32}$ Woudstra and Roth, A History of Groves, 151

${ }_{33}^{3}$ Lynch, What Time Is This Place? 111

Wassilieff. "Horticultural Use Of Native Plants"

${ }_{35}$ Bowring, Melancholy and the Landscape, 157.
This content is unavailable. ease consult figure list for further details.

Fig 6 .

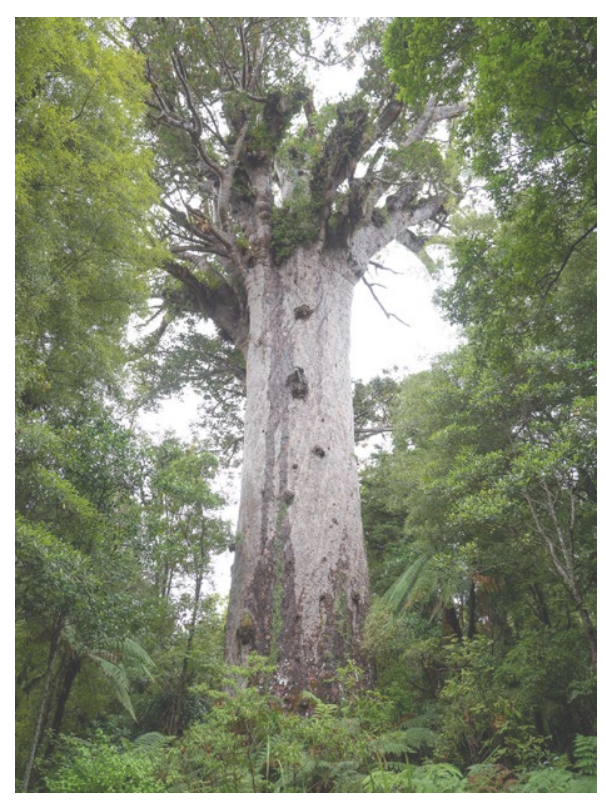




\section{Reflection}

The certainty of death should see more importance placed on the design of spaces for the dead. Yet, our cemeteries have been removed from the interconnectedness of human culture and ecology. Economic and functiona concerns have taken precedence in cemeteries over the ecological, social, sense of sacred and experience. If current practice continues in the face of ecologically vacant concrete fields of death spreading into the disconnected rural realm. This literature mobilises the design-led research to explore reshaping the way we experience death. Utu, whenua and tapu present themselves as useful drivers in reimaging our connection to landscape, death and life. Landscape architecture should challenge current practice and explore alternative burial methods as a mode of freeing cemeteries from the restrictive criteria of current siting. No studies were found that investigated the role of vegetation, topography, hydrology and geology in Aotearoa's memorial context. Personal fieldwork into how these realms affect bodily experience can catalyse design opportunities in Wellington's deathscapes. A methodology is proposed for entwining all these aspects together to form an experimental practice for landscape architecture, that taps into the vast potential our landscape offers for the richness of cemetery design.
Dying in Aotearoa

Map of Cemeteries

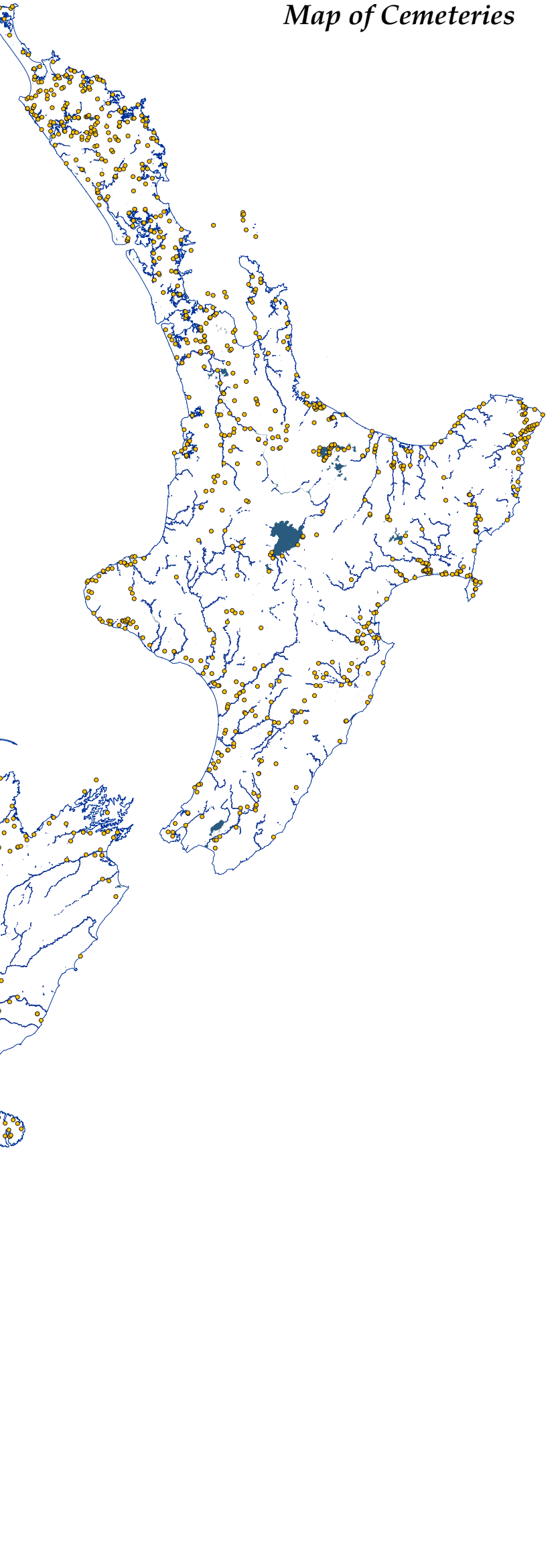

Cycles of Opportunities

CYCLE OF PROBLEMS

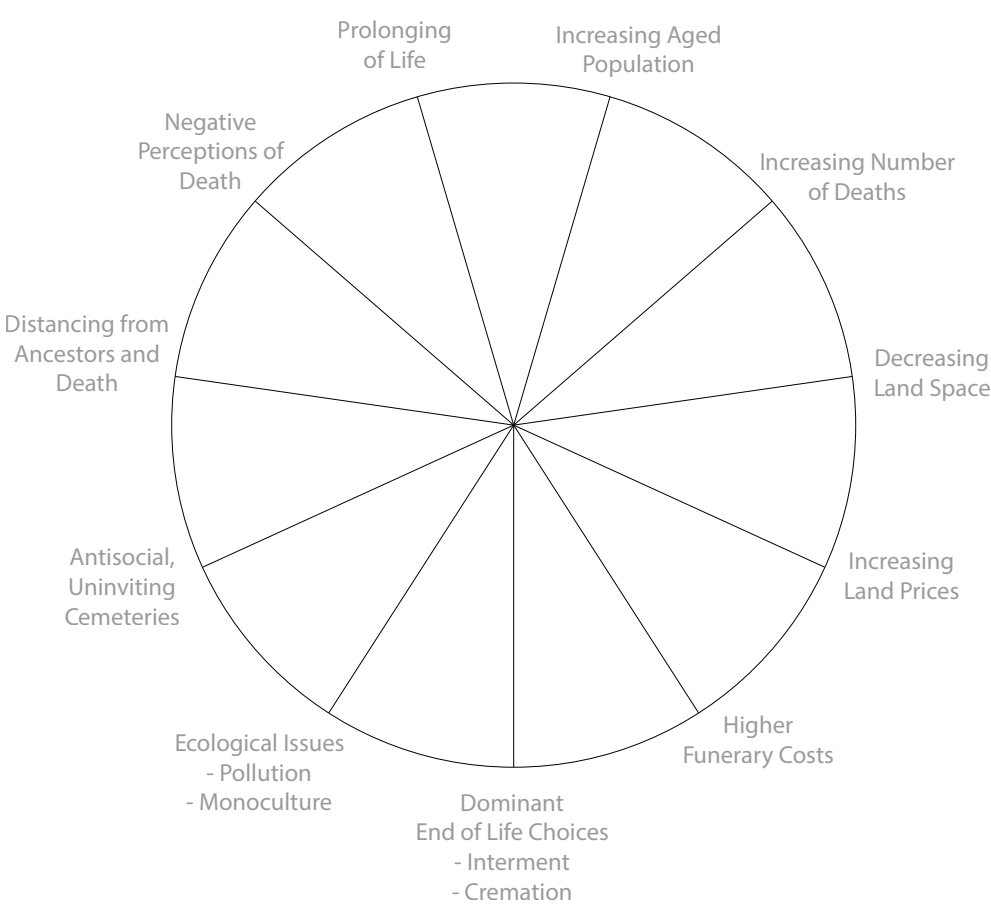

CYCLE OF OPPORTUNITIES

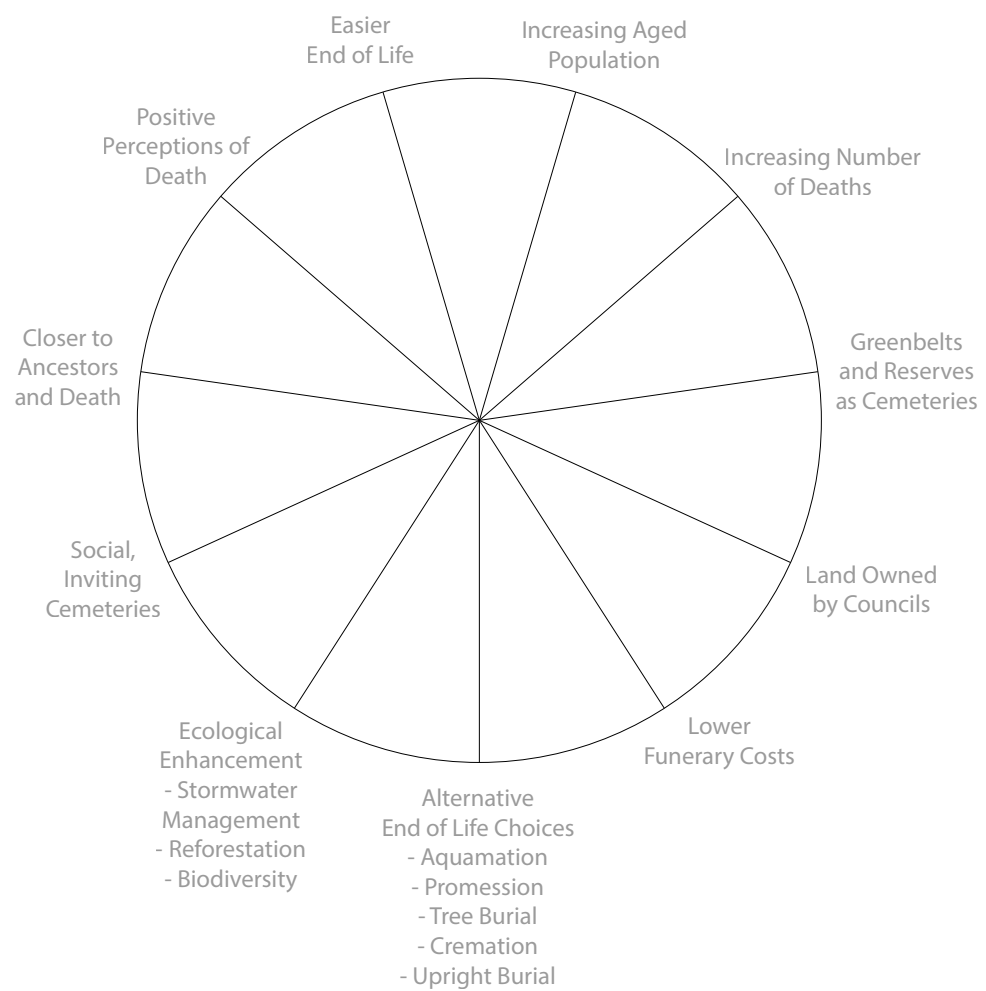




\section{Chapter Three - Māori Customs and}

\section{Death in an Ecological Sense}




\section{Te Ara Wairua}

The Pathway of the Spirits

In Māori belief, a persons spirit departs Aotearoa at Te Rerenga the ancestral homeland of Haw to a-nui This means all spirits mail journey north.

This spirit journey north influenced aspects of daily life for living Māori, such as the doors of pataka (food storehouses) being oriented north.

This was so spirits travelling from the south would not be able to enter and make the food tapu.

Here a spirit map created by the trig points in the North Island. In this way it shows the concentration of spirit energy pathways across North Island maunga. Wellington, Hawkes Bay, East Cape and Taupo being particularly concentrated areas.

Once western travelling spirits reach Ahipara they follow a series of prescribed areas on west coast which must be passed by the spirits. Likewise, there is an eastern journey for east coast spirits

\section{Landmarks of the Spirits}

(13) Haumu at the head of the beach, where spirits from both coasts converge. (14) Maringinoa (weeping spirits) is where the spirit would

(15) The spirits then descend into the valley of Waingurunguru (murmuring-waters). Very still and swampy, where a stream flows slowly, if at all. A faint droning is said to be heard, coming from everywhere and nowhere.

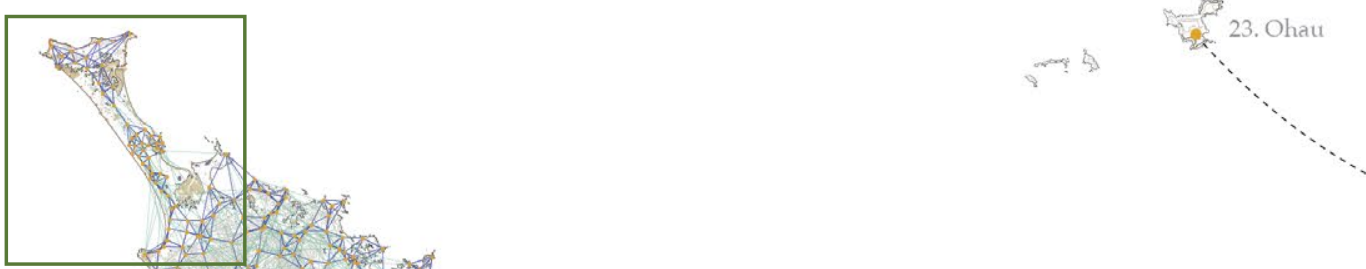

(21) Te-wai-Whero-o-Rata is the ancient pohutukawa perched at the descend the long root into the sea where the entrance (22) Moetata, to the underworld is concelau, waving kelp.

From here the spirits swim along $\mathrm{Te}$ Ripo-a-Maurianuku (meeting of the (23) Manawatawhi in the Three Kings Islands.
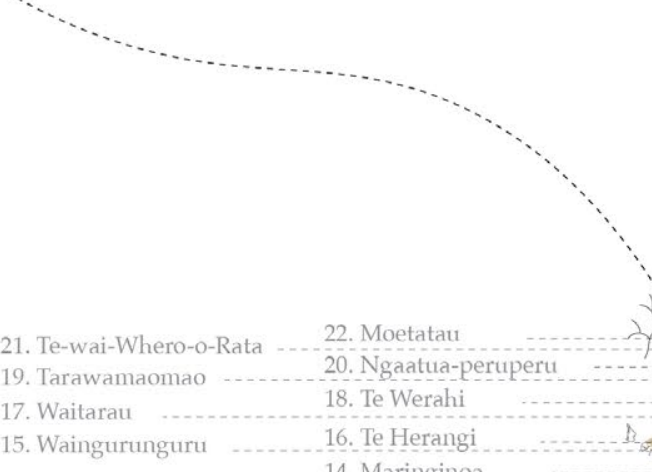

Manawatawhi means last breath as the spirits come up for the last glimpse of their island home before heading to Hawaiiki. 


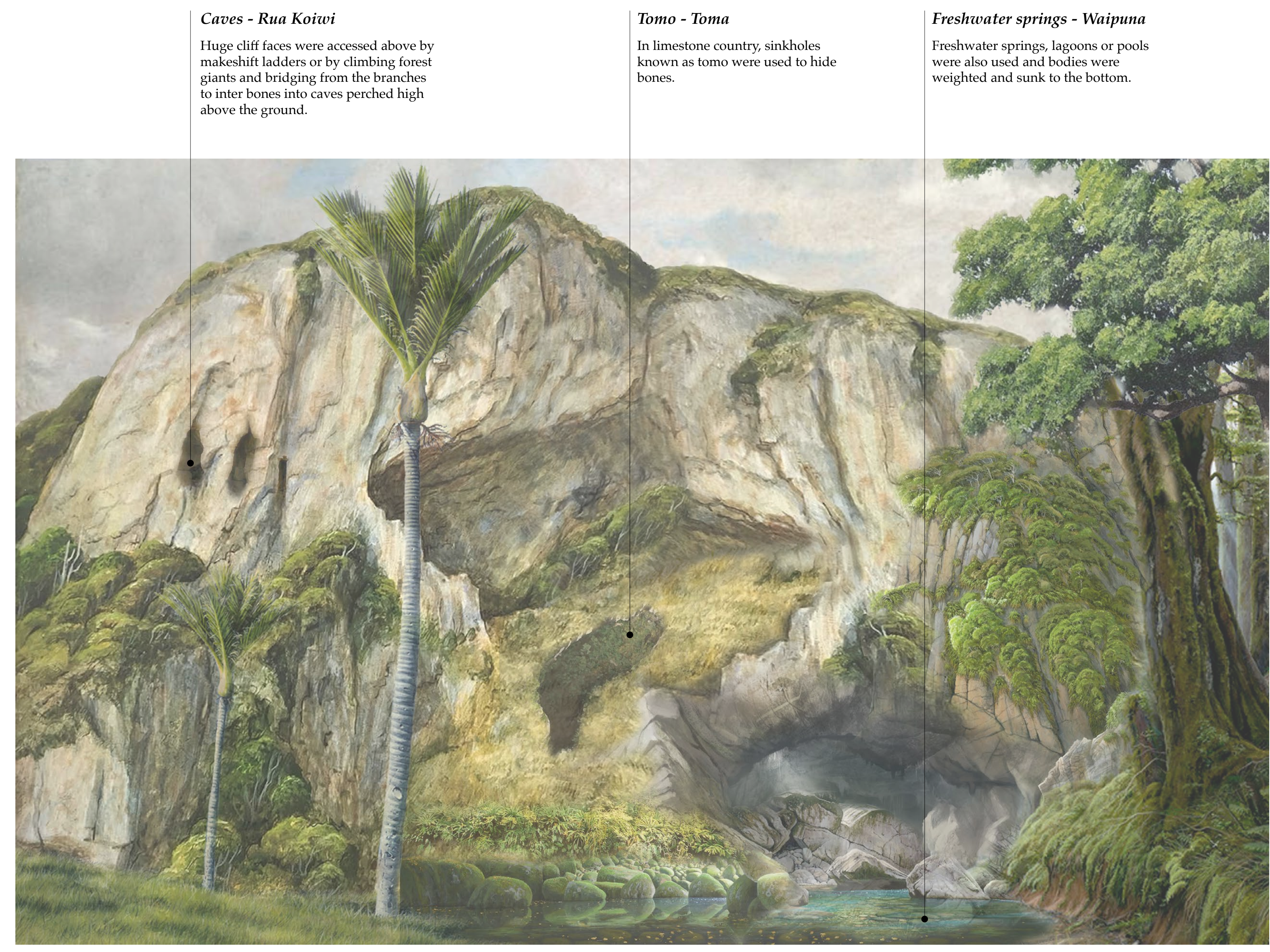

Burial in

Limestone Country

Māori Burial

Burial grounds are termed urupa.

In-ground burial seemed to be less

common historically, when it was

confines of a village.

A cave or chasm where bodies or

bones of the dead were placed is

called a toma, whara, and rua koiwi.

If the dead were buried, or otherwise disposed of outside the limits of the fortified village, then secret disposal was generally necessary.

The tapu nature of these bones often meant great lengths were taken

to hide them. The creativity in the

hiding areas of bones shows a great

understanding of the environment

in which Mãori have forged over a

thousand years of settling this land.

They were often reflected by their

locality and ecology. 
Tree Hollows - Uru Koiwi

In forested lands, like that of Te Urewera, bones were stored in the hollow trunks of species like pukatea. This often envolved climb tall trees to deposit them.
Swamp Burial -Wairepo

Sometimes the dead, would be gently tamped into the soft mud of swamps.
Astelia Epiphytes - Wharawhara

Clumps of Astelia epiphytes high up in trees provided a leafy domain for bones.

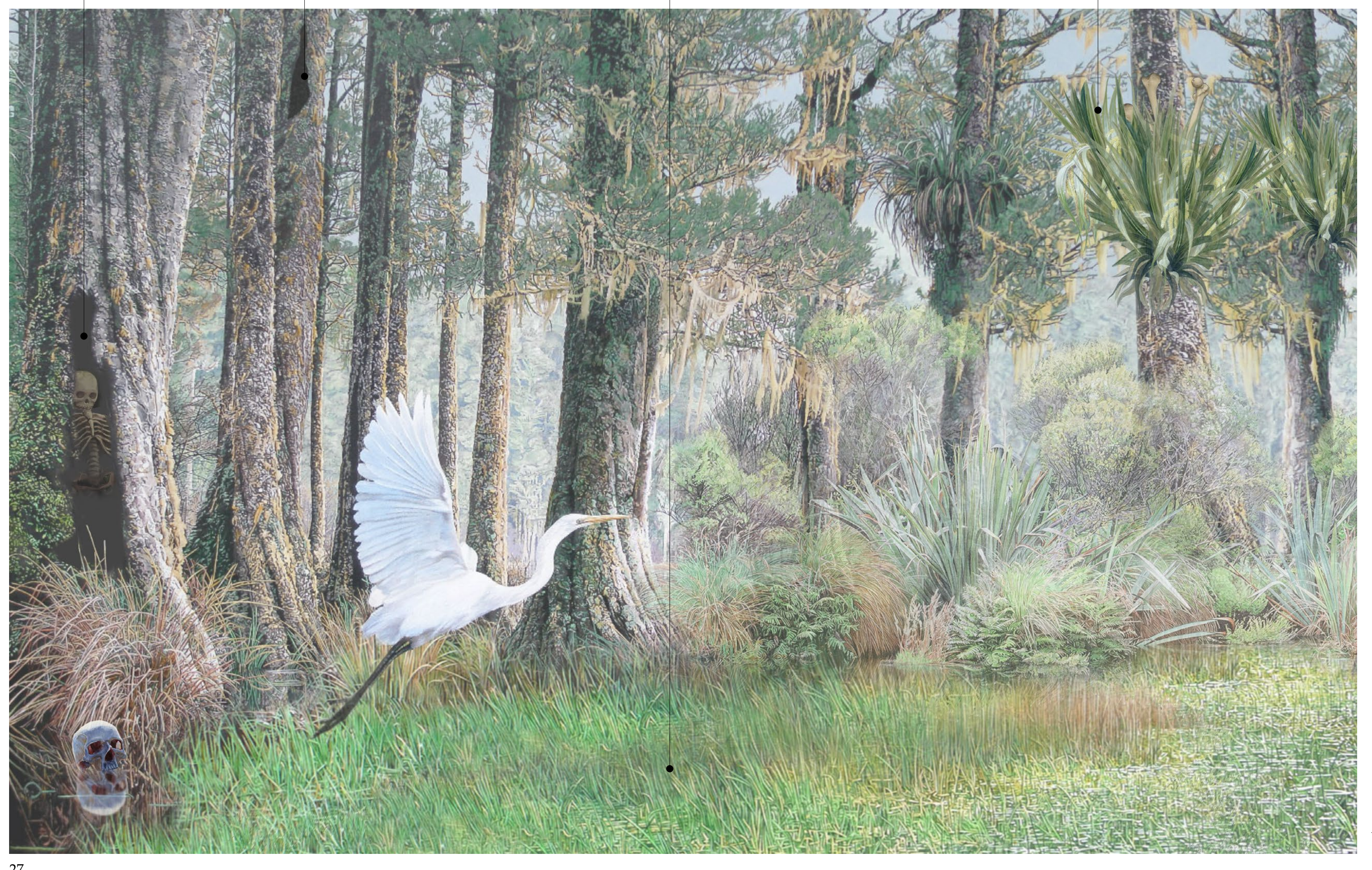

Burial in

Swamp and Forest Lands 


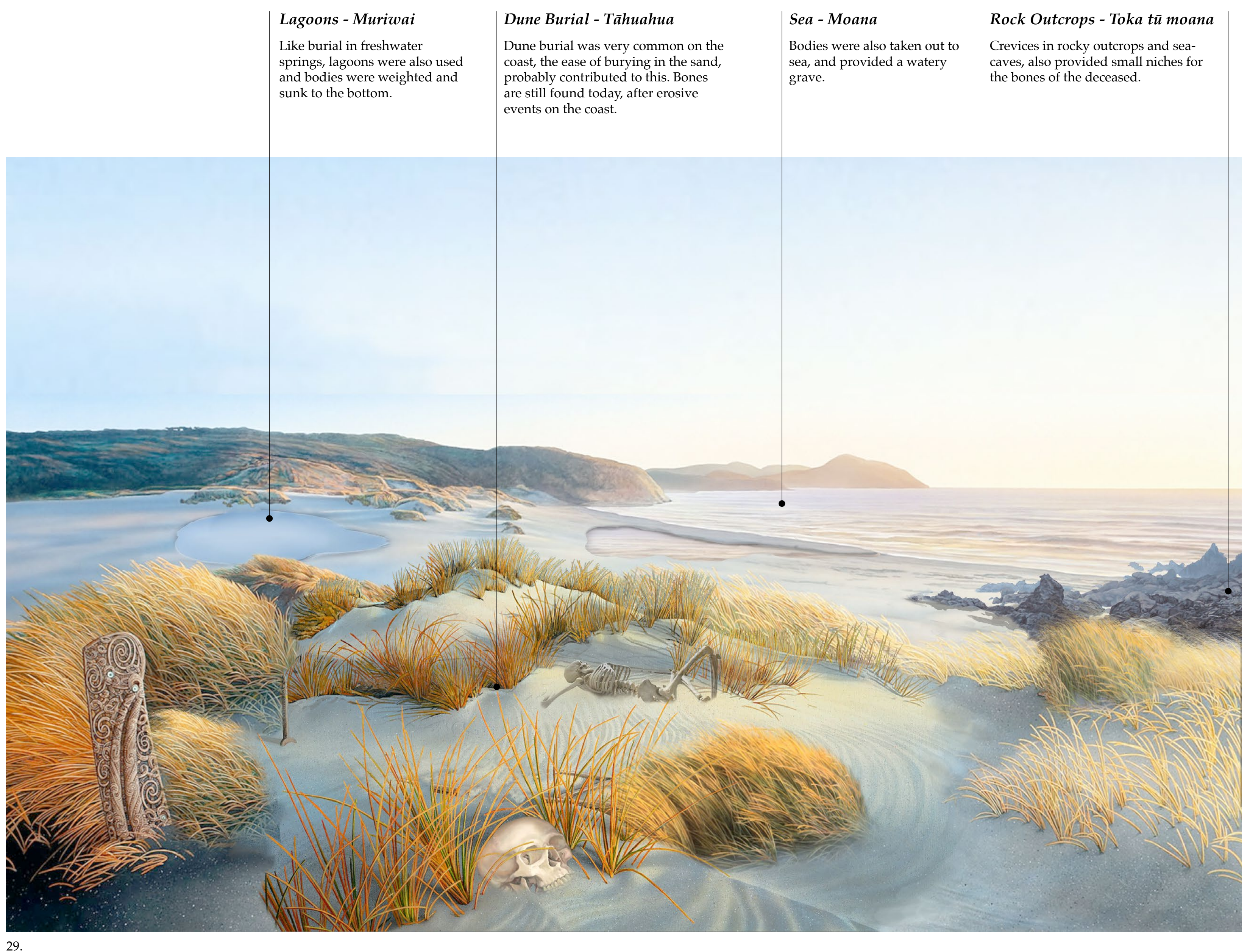

Burial on the Coast 


\section{Alternate Burial Methods}




\section{LANDSCAPES OF \\ BURIAL}

The designed ecology of cemeteries cusses on grasslands.

However, this is not appropriate in he flora never evolved into grase or prairie meadowlands. These

ecological models which are popular in internationa cemeteries are often imported here, with detring to ecosystem of New Zealand.
Traditional Lawn Cemeteries

These have remained the dominant rend in burial for centuries.

Historically grazing anima were to the to a two-dimensiont rave lawnmowers and for further flat and sunken below the lawn level.

The graves were generally dug "six feet under", partially from fear of reanimation of the dead and beliefs around disease and hygiene. This deep layer of the soil is often very inert and the body can take a century to fully perish. The popularity of grandiose caskets meant the graves were generally wider, which uses more land. However, the depth can allow further burial atop of the last for other members of the family.

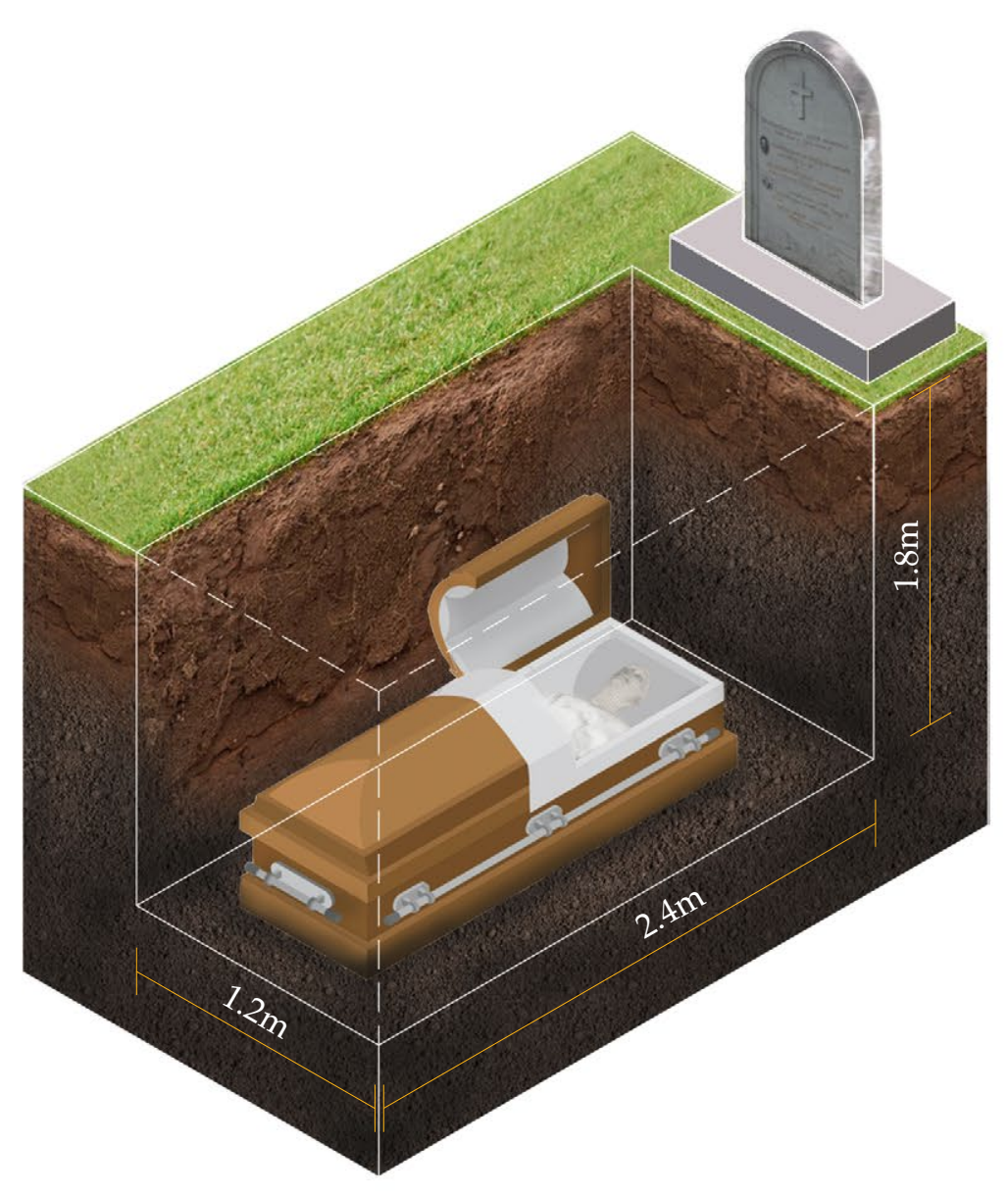

Natural/Green/Eco Burial Cemeteries

Natural burial is becoming an

increasingly popular option for many

The landscape is seeded or allowed

to regenerate in meadow grasses and

fowers. The renew appreciation

for the aesthetics of meadows is

seeing this method quickly replicated

ecology occurs up to knee-height

The graves are dug to a depth of fifty centimetres to a metre. This leaves

the body in to a most bive

body and casket are recycled by

he environmet ach faster th

tradition means. Depending

the the tenure of the grave plot, an

endless amount of further interm an

may be possible.
Forested Cemeteries

Burial in the forest has largely been ignored. The few examples of such are generally from countries where the natural growth of the understory is dense and multi-ayered. The flora occupies every available gap in dimensions.

The research explores how burial entwined with New Zealand's ecology. The graves will utilise the same dimensions as natural burial and native plant material will be explored in casket construction.

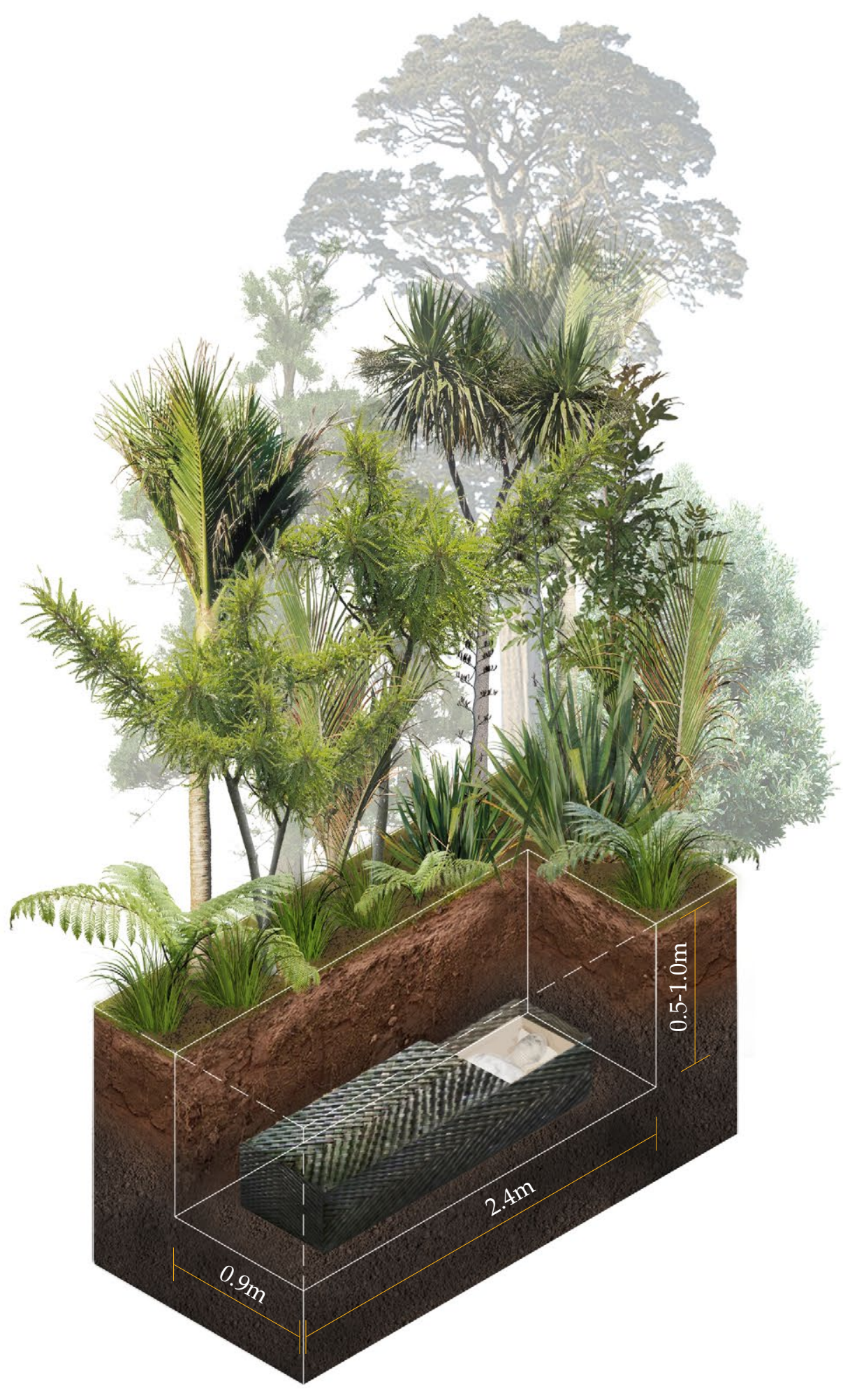


Alternative Burial

Methods

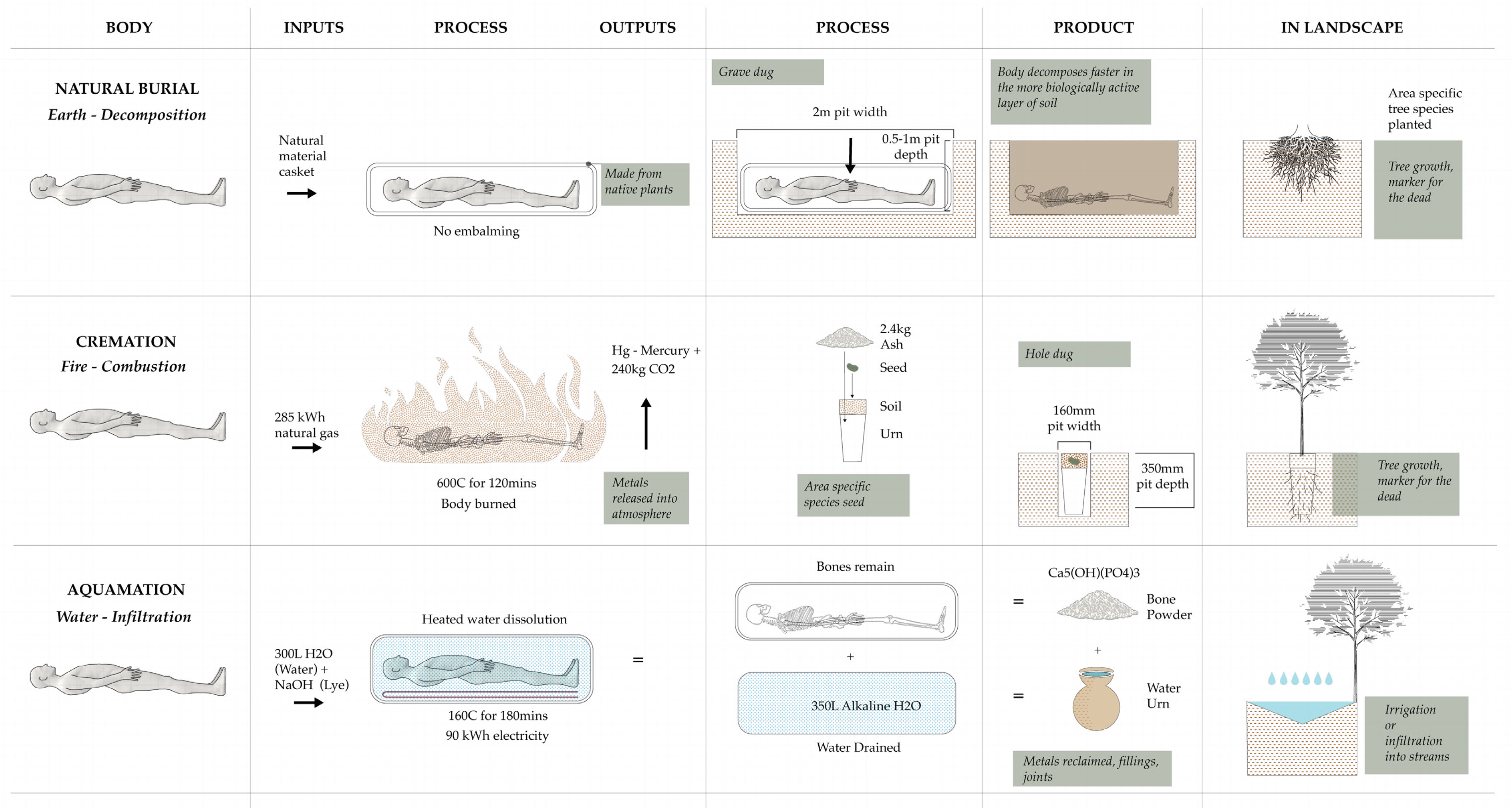




\section{Selected Case Studies:}

\section{Discoveries}

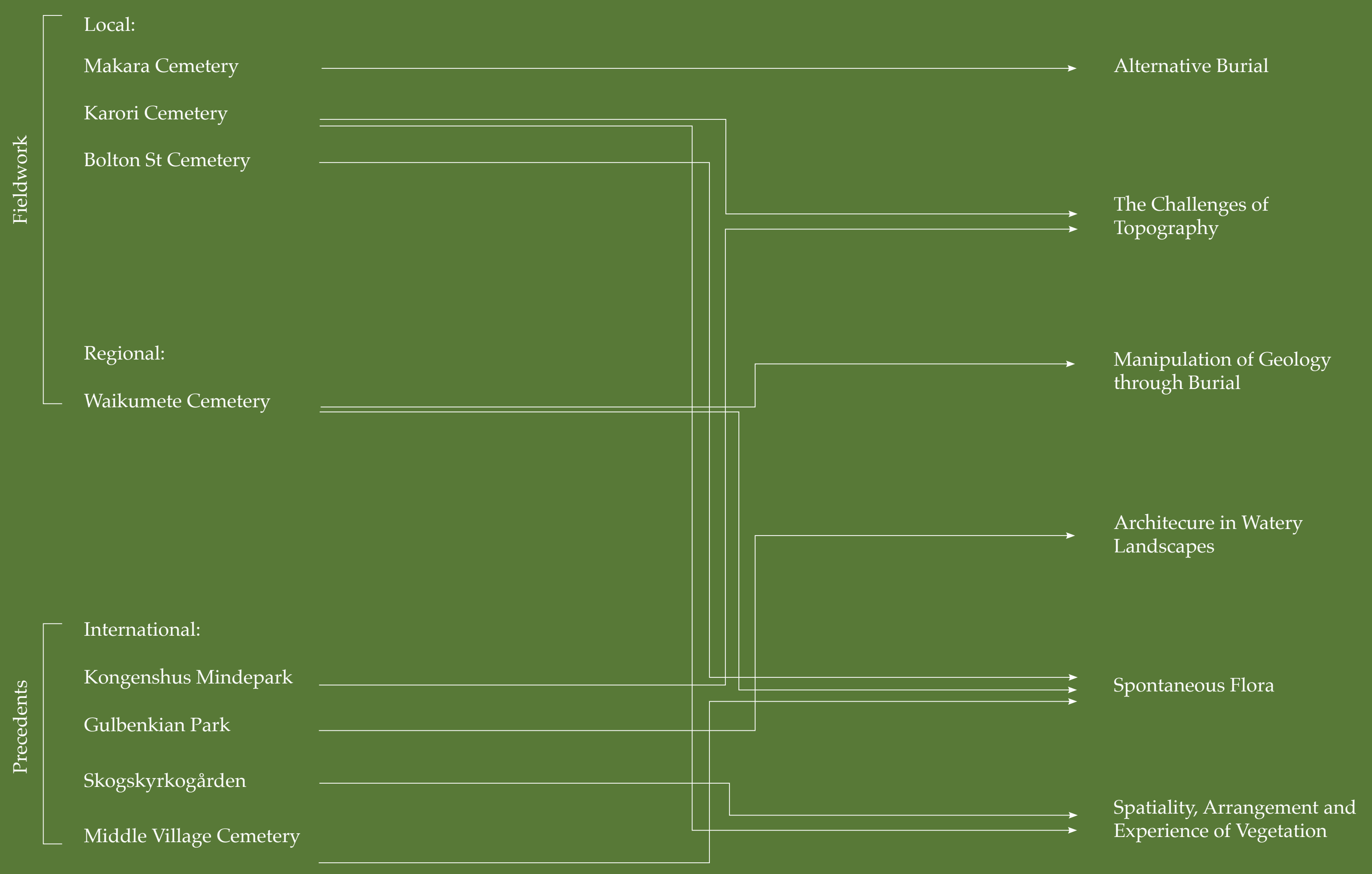




\section{Local Cemeteries}

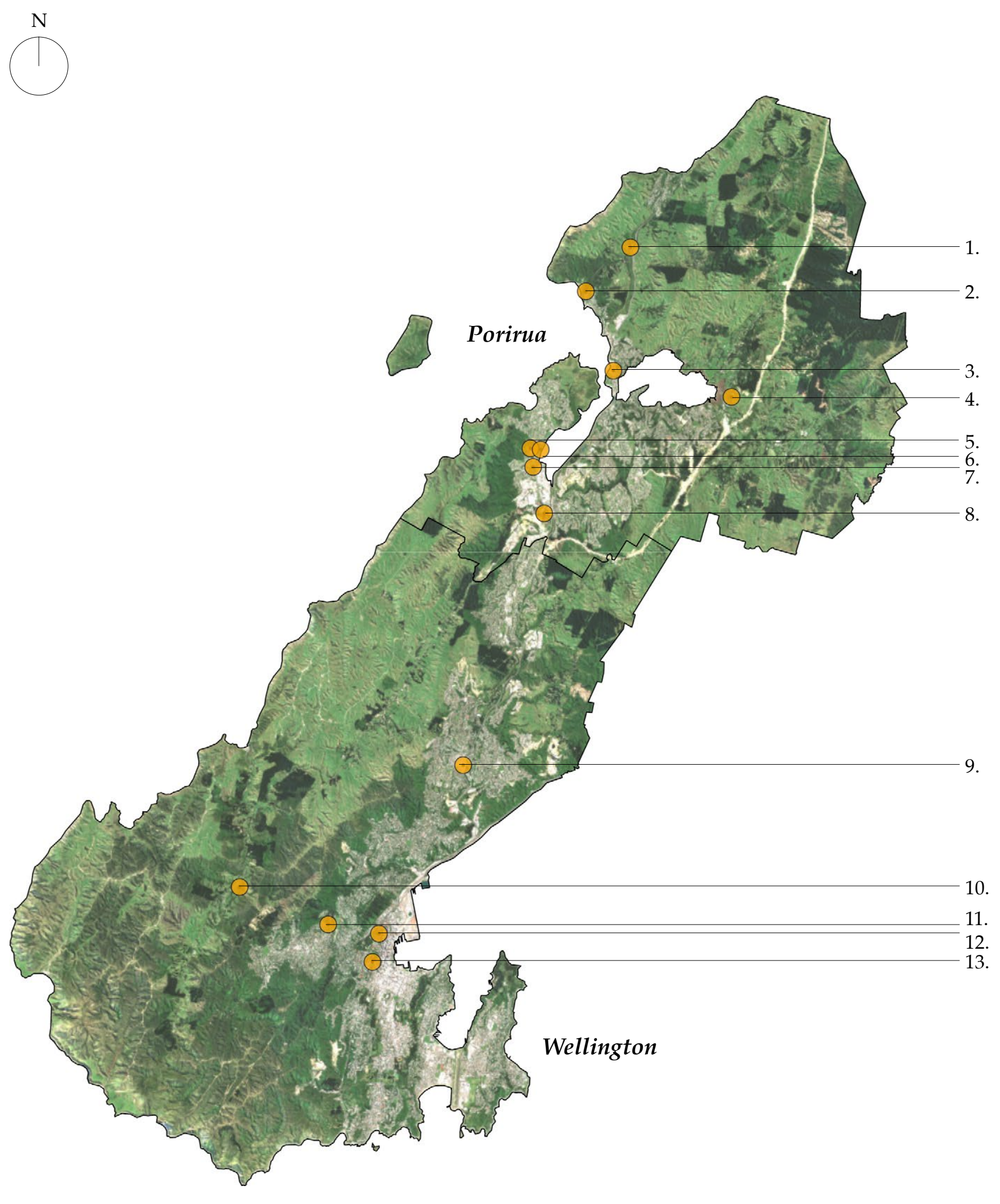

1. Whenua Tapu Cemetery

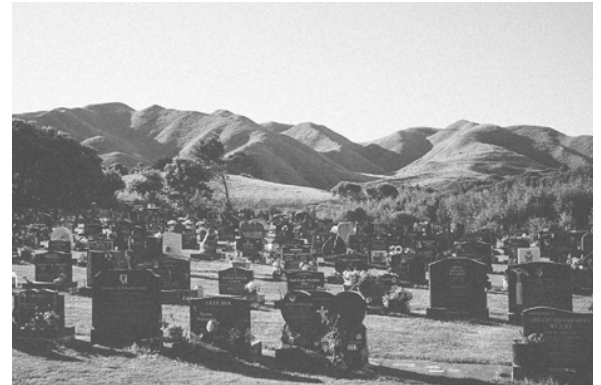

4. St Alban's Cemetery

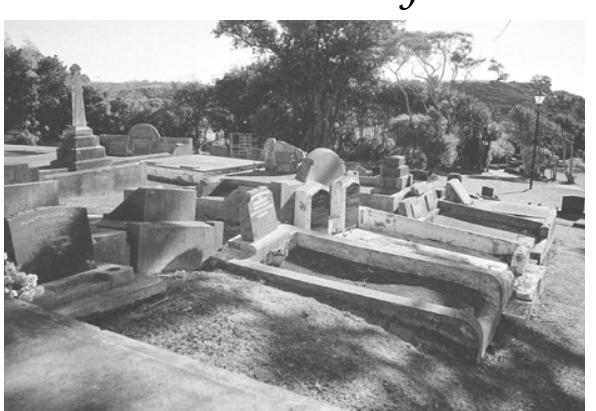

7. Urupa (Te Arataura St)

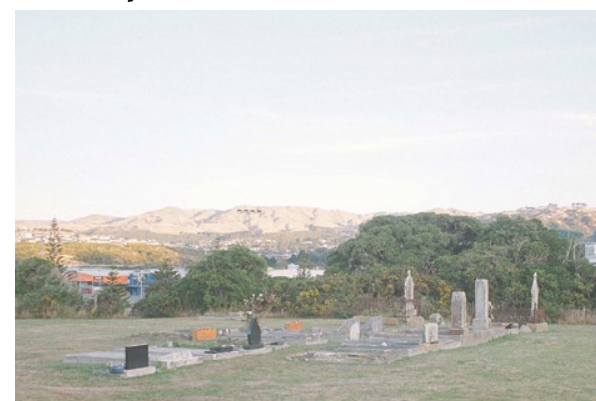

10. Makara Cemetery

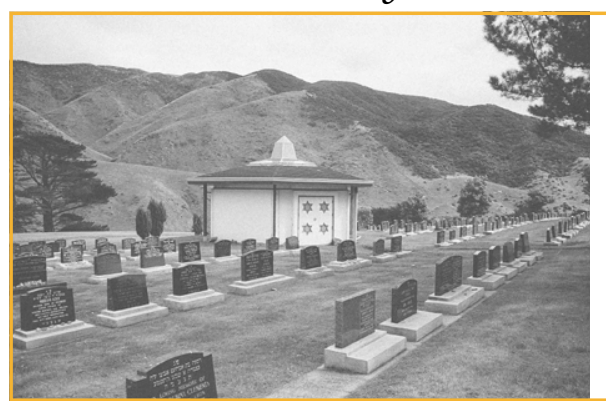

13. Mount St Cemetery

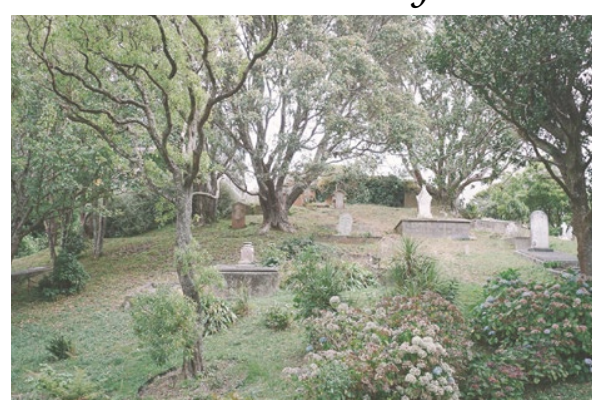

2. Hongoeka Urupa

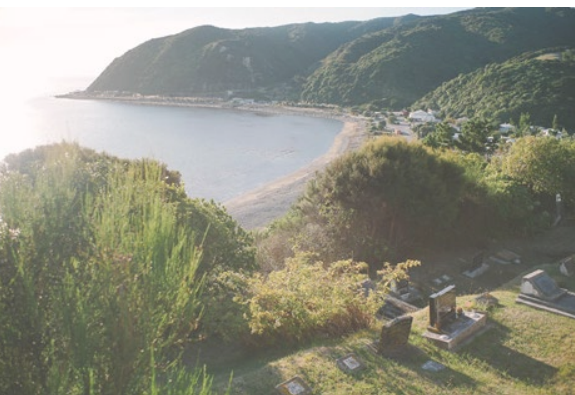

5. Urupa (Puaha St)

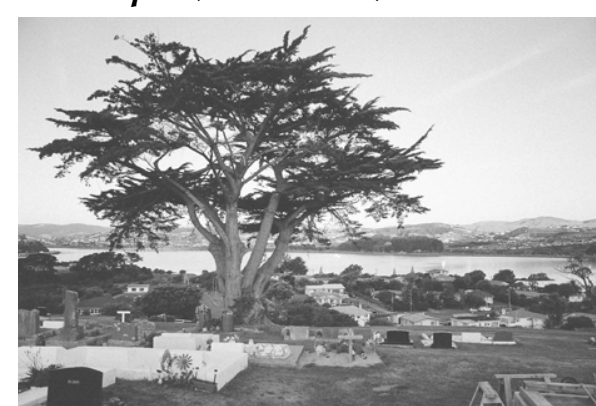

8. Porirua Cemetery

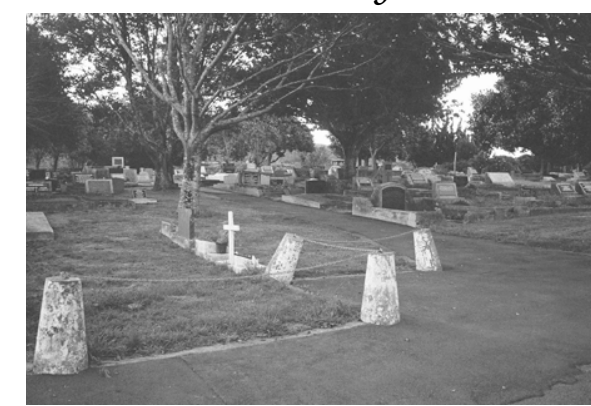

11. Karori Cemetery

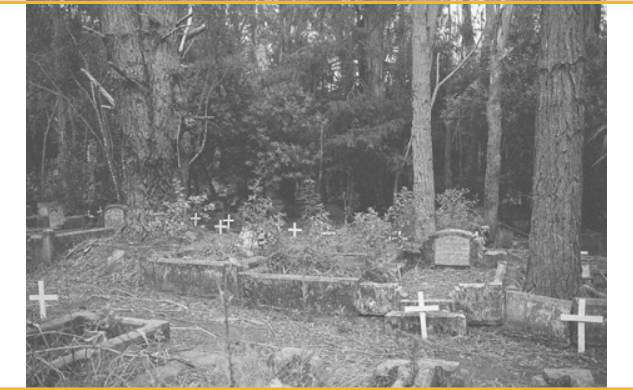

After investigating regional

Wellines and urupa from

Wellington to Porirua, three were

selected for their relevance, site

conditions and discovered design

potential. Makara, Karori and Bolton

t Cemetery. 


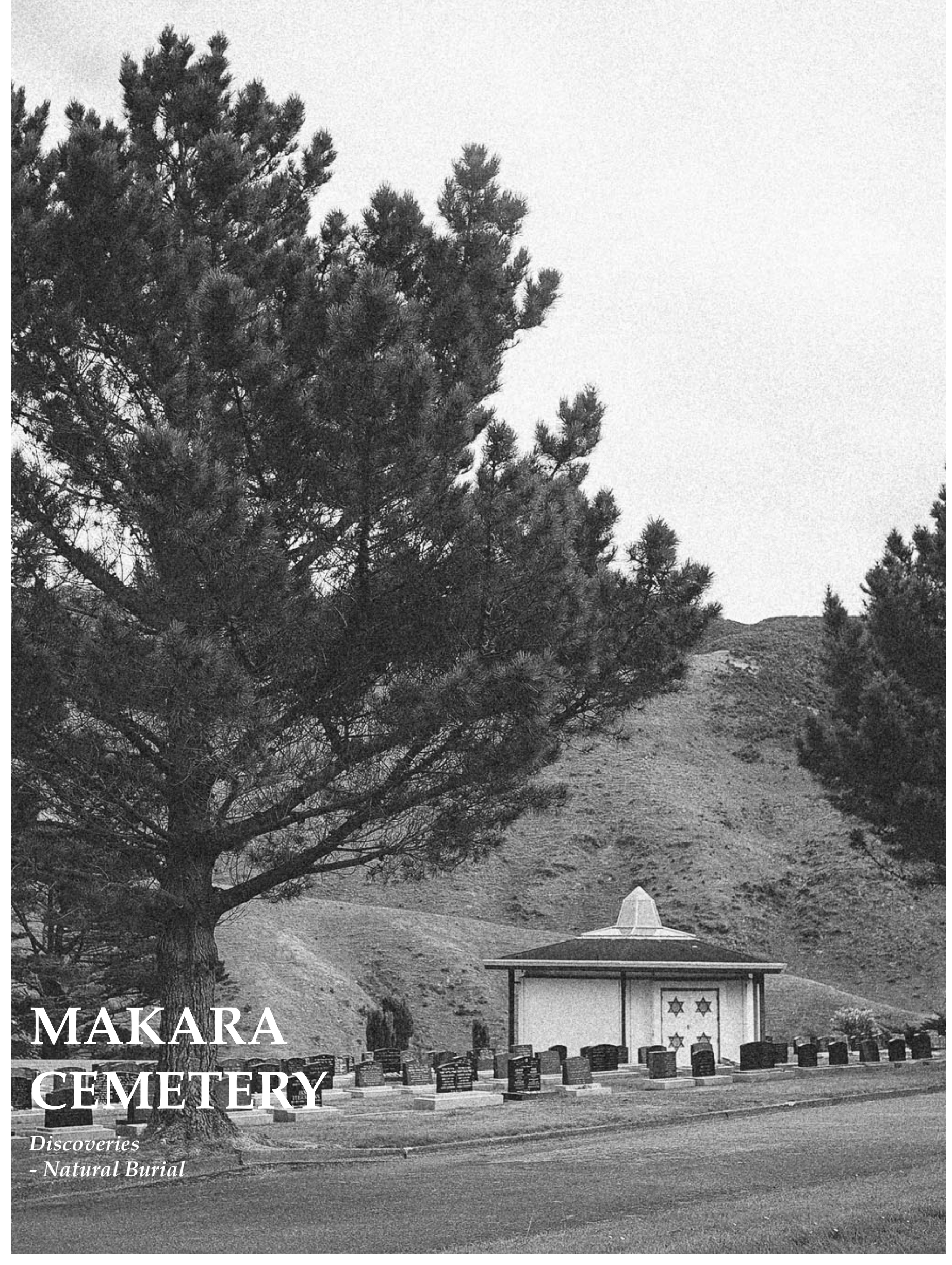

Natural Burial Area of Makara Cemetery
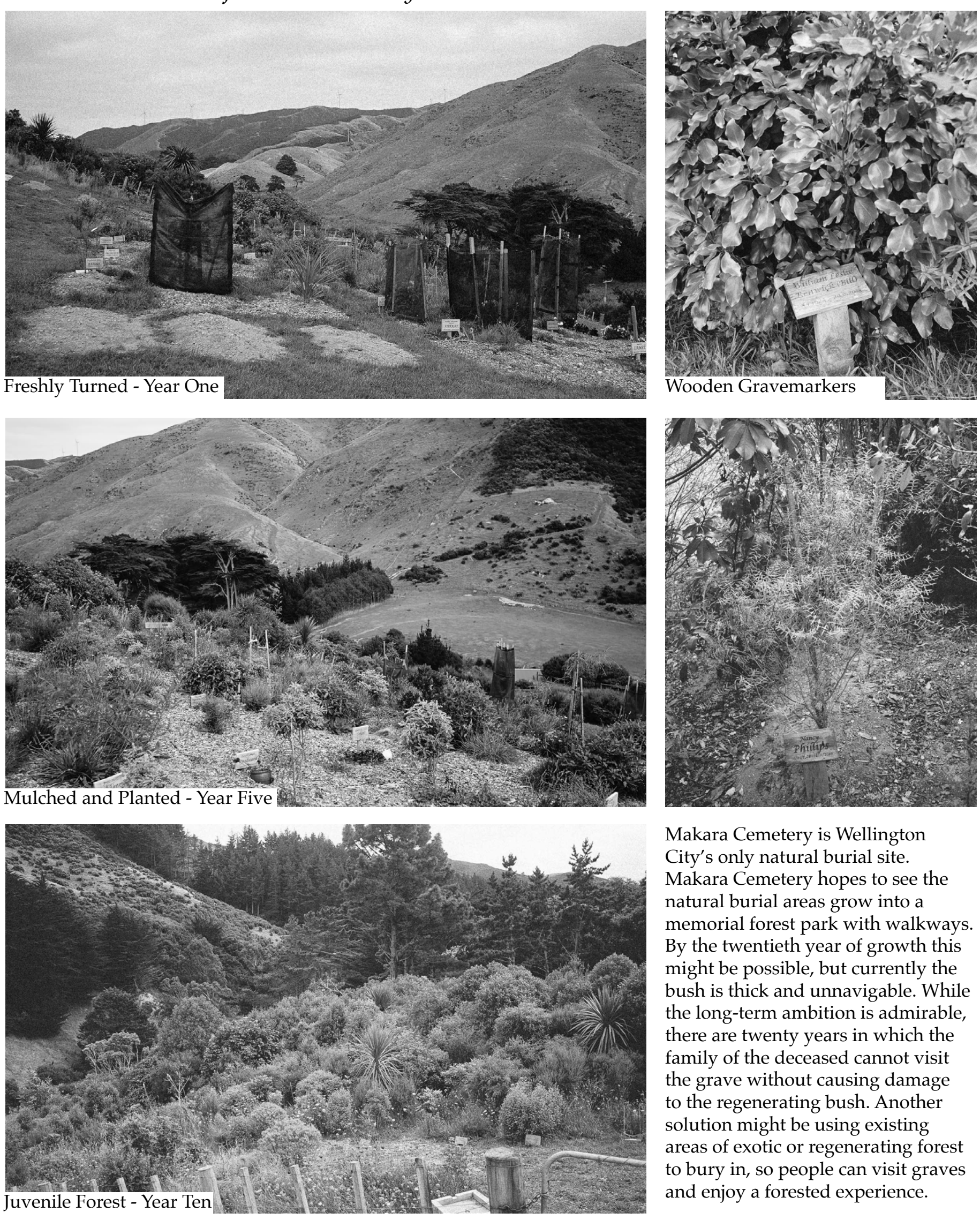

Makara Cemetery is Wellington City's only natural burial site.

Makara Cemetery hopes to see the

natural burial areas grow into a

memorial forest park with walkways. By the twentieth year of growth this might be possible, but currently the bush is thick and unnavigable. While the long-term ambition is admirable, there are twenty years in which the family of the deceased cannot visit the grave without causing damage to the regenerating bush. Another solution might be using existing to bury in so people can visit forest to bury in, so people can visit grave and enjoy a forested experience. 


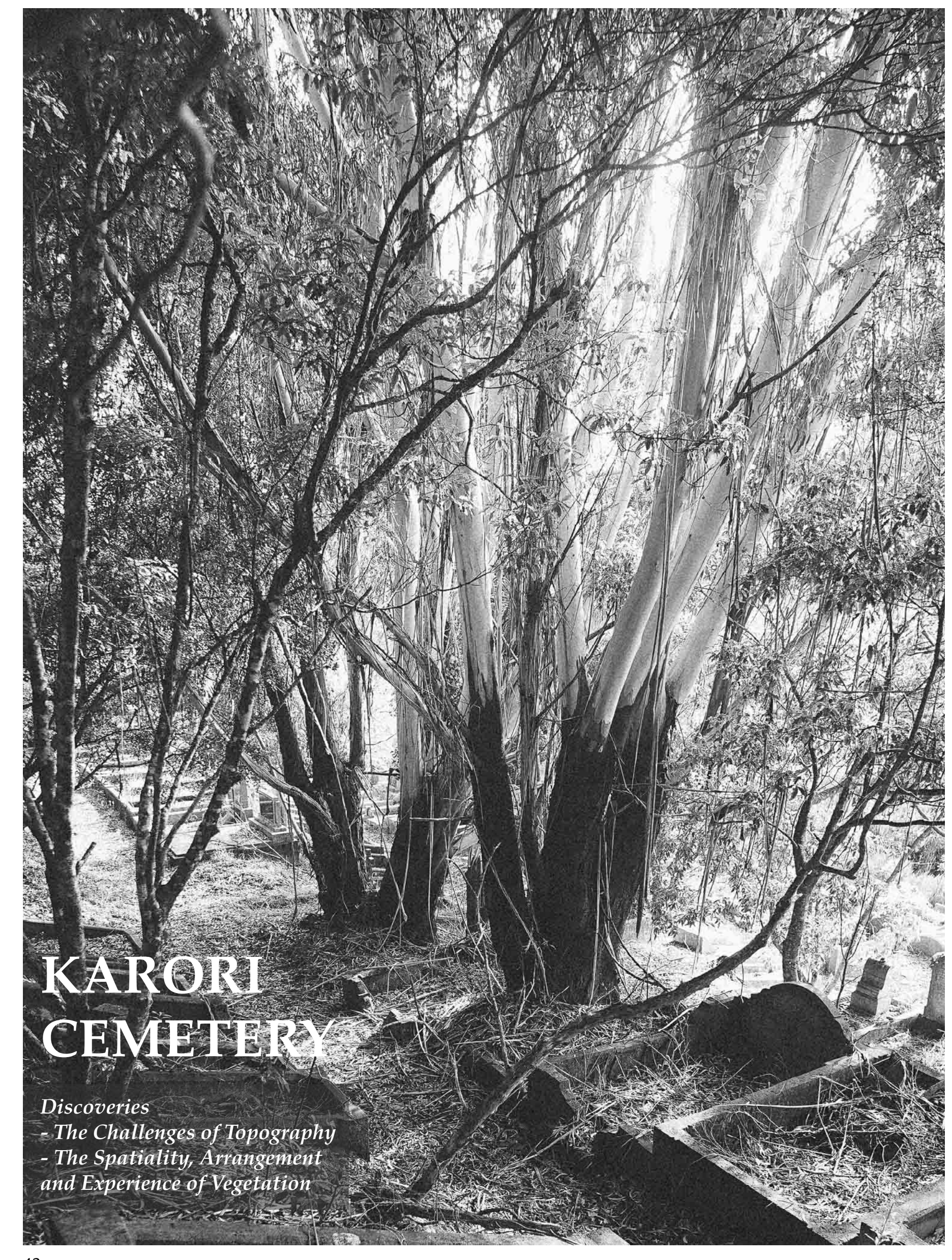

The Challenges of Topography
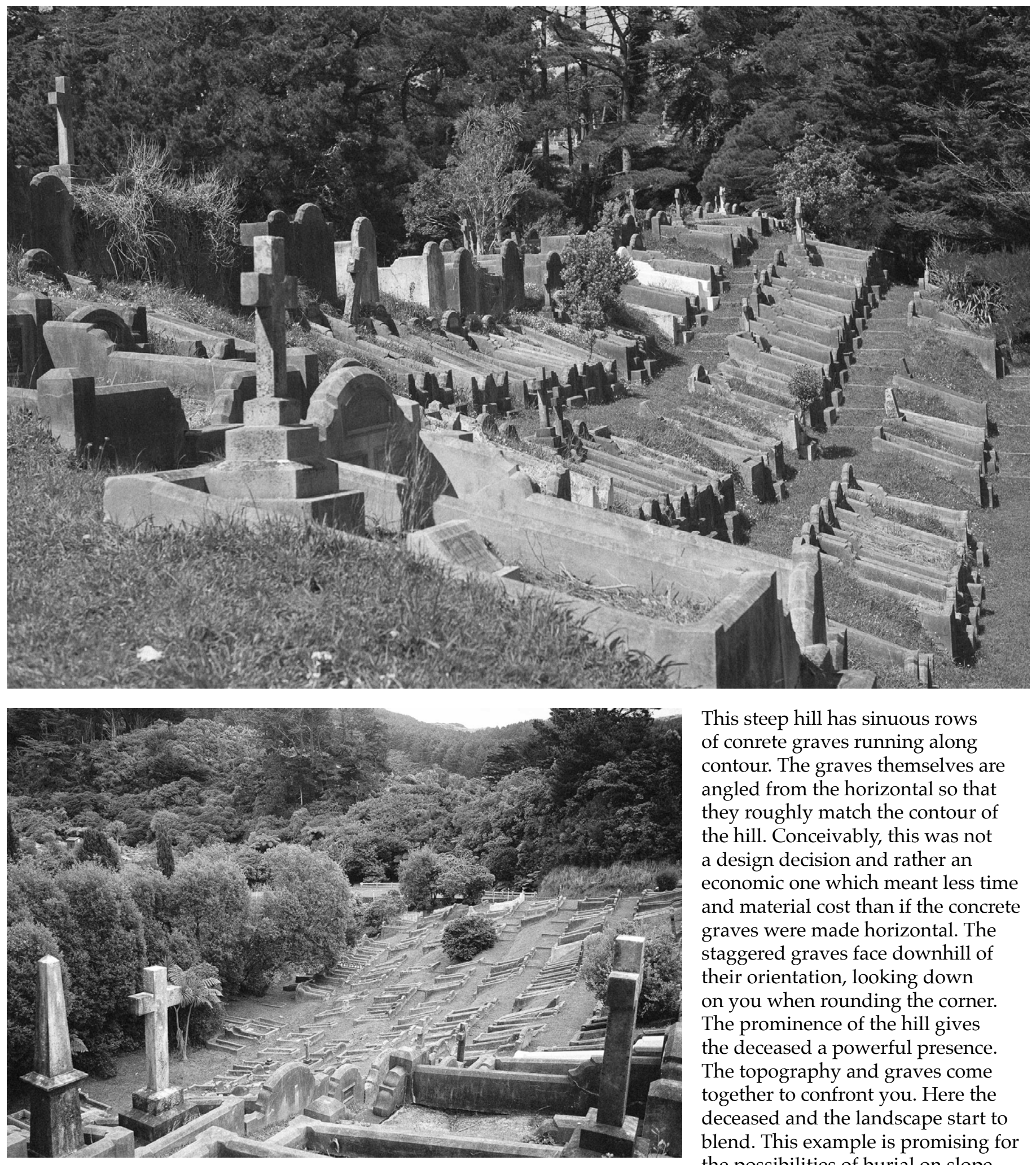

This steep hill has sinuous rows of conrete graves running along
contour. The graves themselves are contour. The graves themselves are
angled from the horizontal so that they roughly match the contour of the hill. Conceivably, this was not a design decision and rather an economic one which meant less time and material cost than if the concrete graves were made horizontal. The staggered graves face downhill of their orientation, looking down on you when rounding the corner. The prominence of the hill gives the deceased a powerful presence. The topography and graves come deceased and the landscape start to blend. This example is promising for Karori Cemetery is the second
largest cemetery in Aoteroa, behind Waikumete Cemetery. It is the resting place of over 80,000 people and was established in 1891 to provide more burial space after Bolton St Cemetery ran out.
These photos show a particular area in the centre of Karori Cemetery where Wellington's challenging topography was dealt with in
creative, yet economic way. the possibilities of burial on slope. Karori Cemetery Management Plan also notes that the less demanding are particularly useful in difficult terrain. 
The Challenges of Topography

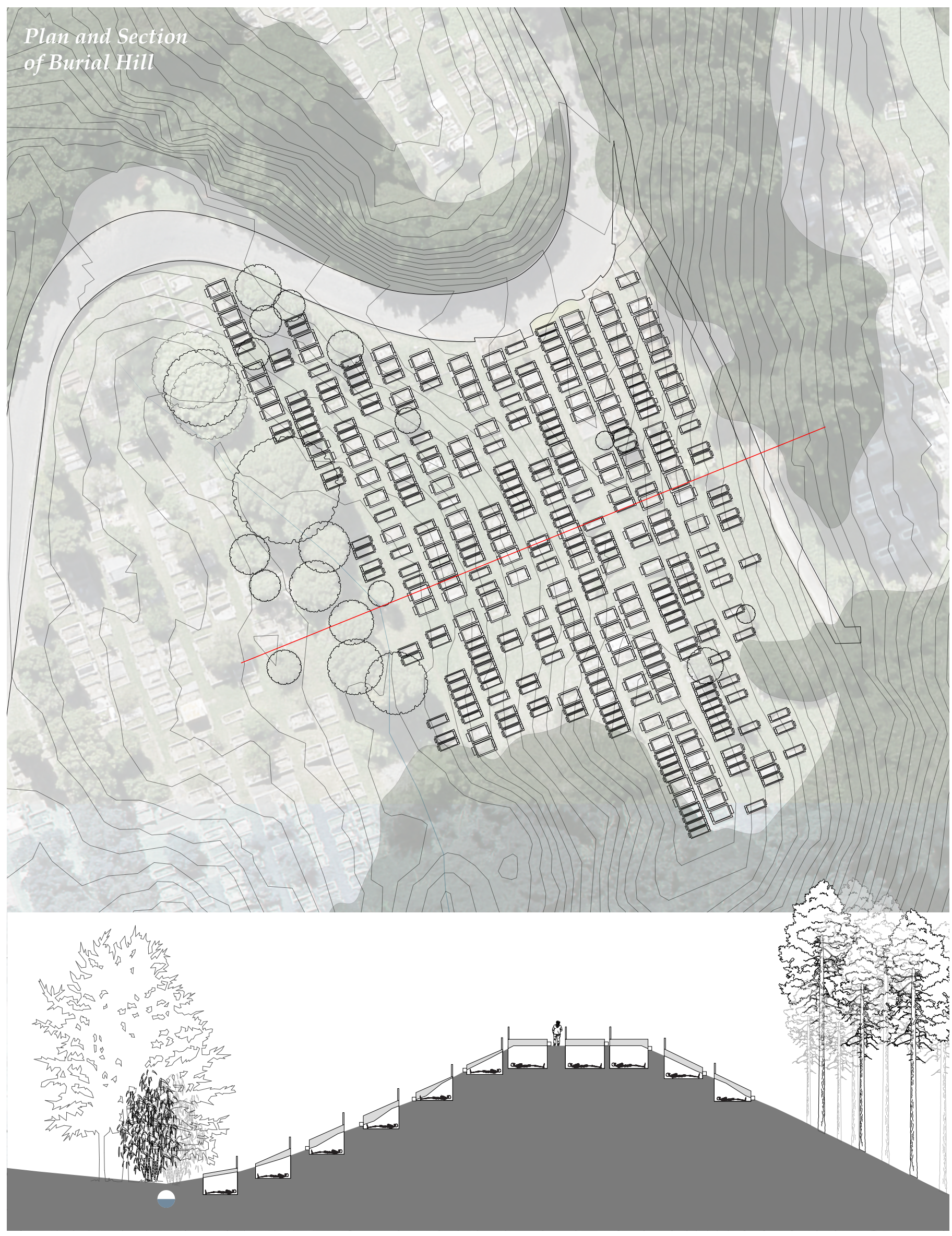

The Spatiality, Arrangement and Experience of Vegetation
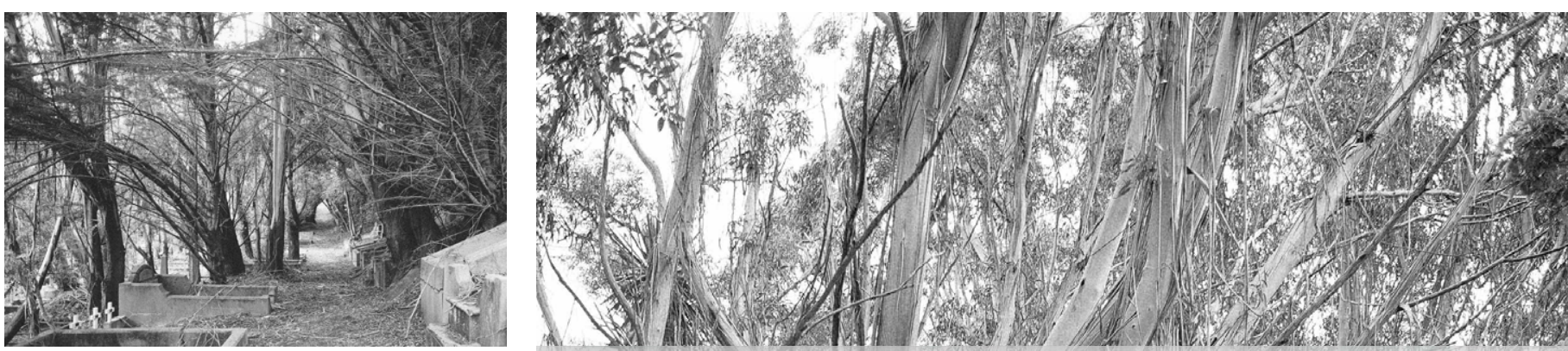

Macrocarpa, with their thin pointy branches reach out and encapsulate you.

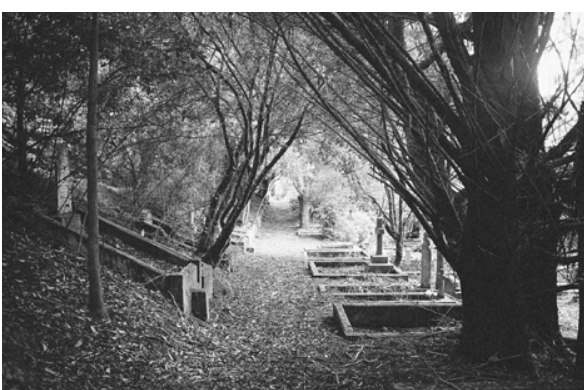

They begin to darken a direct you through a tunnel of light. As you make your way downhill, the graves become progressively more overgrown.

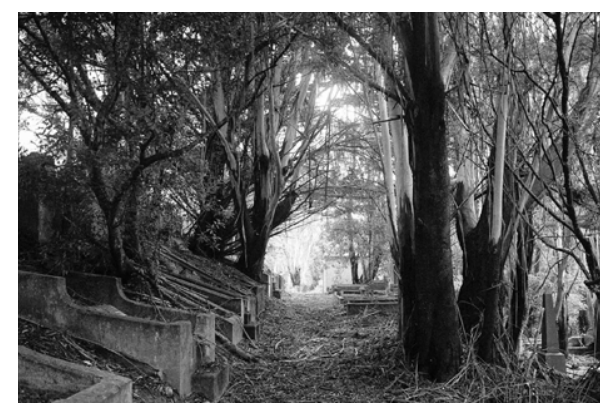

The forest shifts toward Eucalyptus, their trunks are rough and black. Above head height, they begin to branch. These drastically contrasting, smooth and white skeletal branches create a lightness in the canopy.

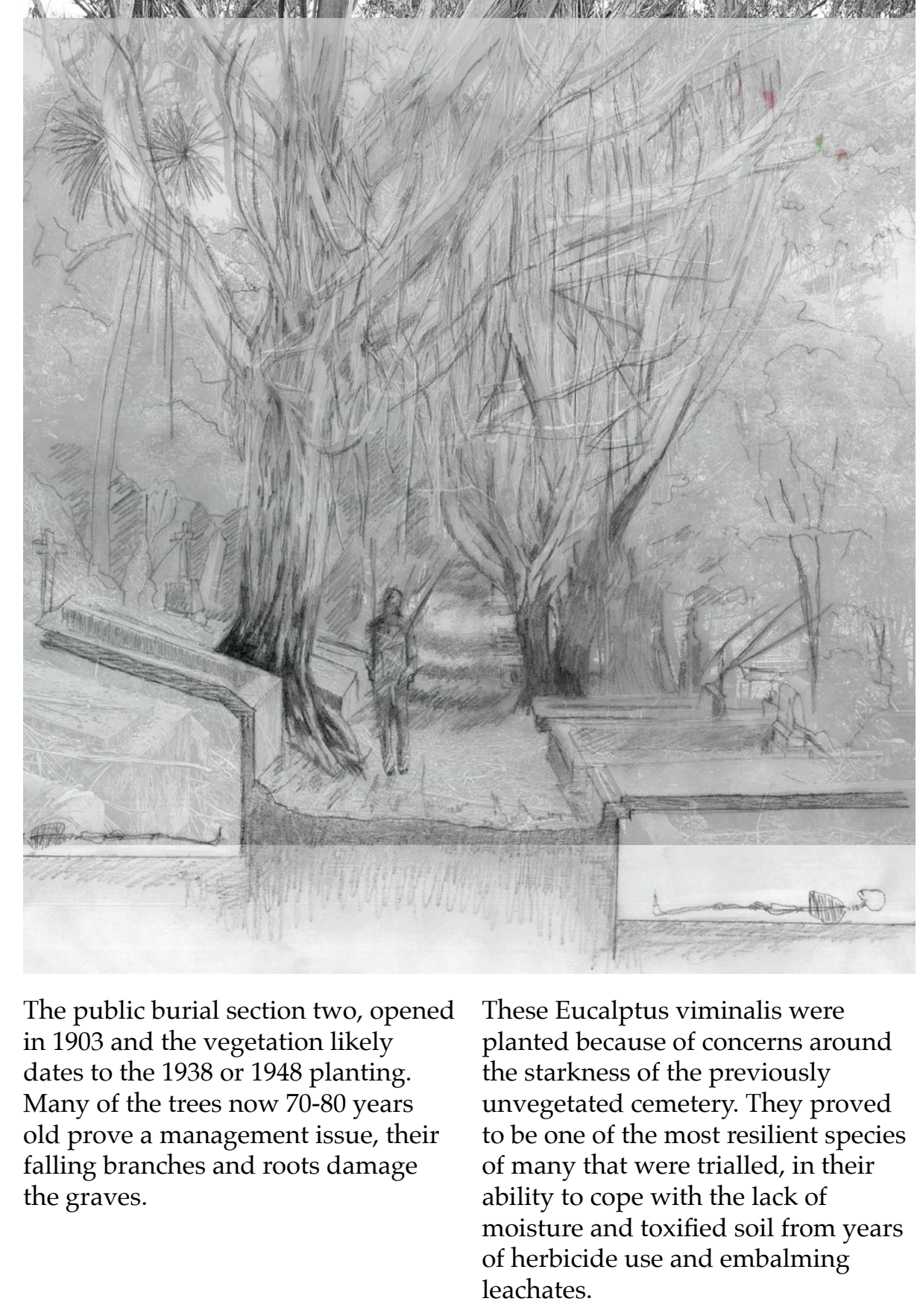




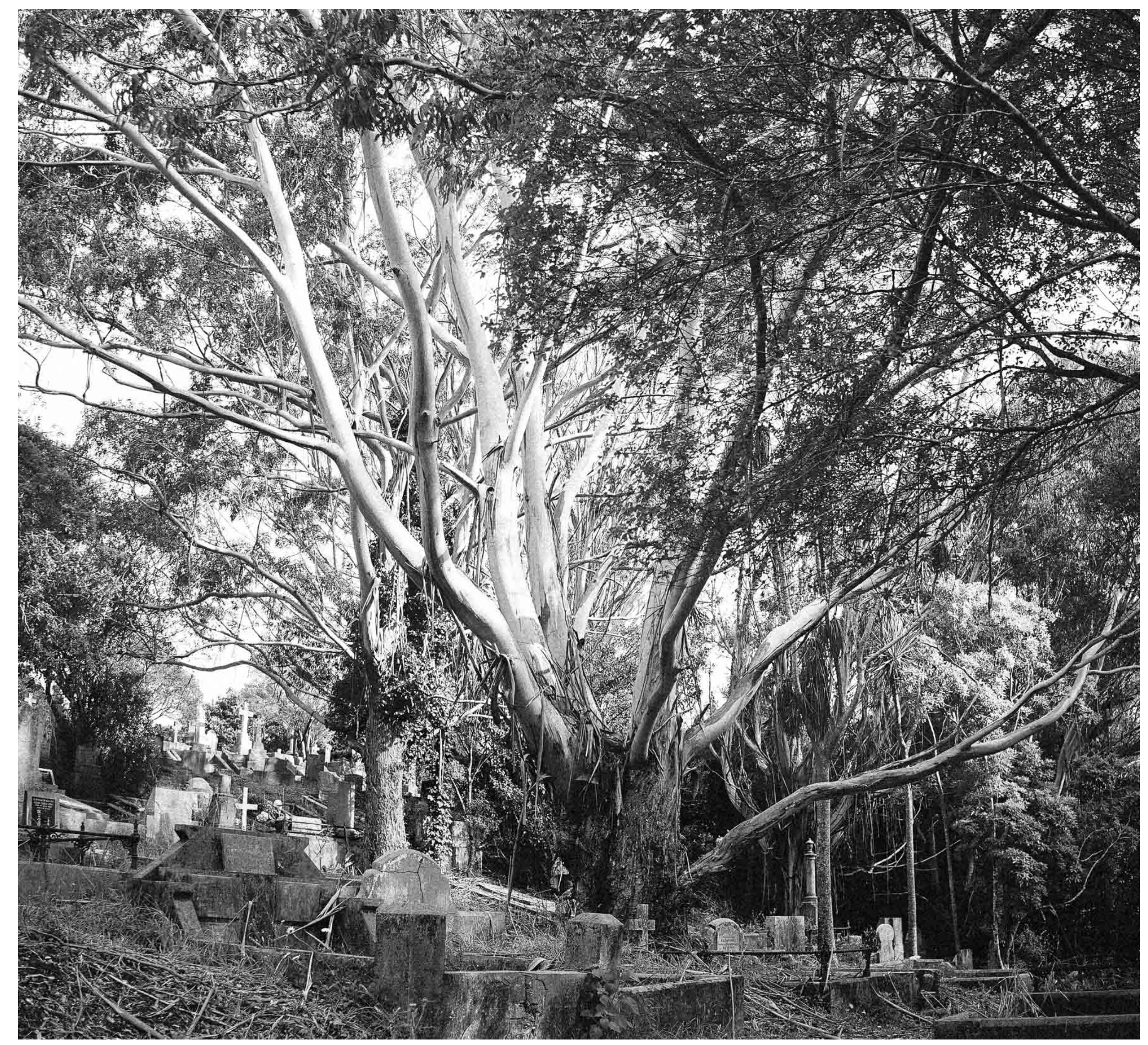

The Spatiality, Arrangement and Experience of Vegetation

The importance a single tree has in These photographs show this process structuring space is evident here. already beginning. The simple white The canopy reaches over 20 metres crosses, help to mark the place of in diameter, its relative lack of the dead within what is already

leaves allows an incredible amount becoming harder to tell as cemetery.

of light into the space below. It also

acts as an anchor for the the graves

surrounding it. Those that are

sheltered by its branches are brought

into a relationship with the tree. The

flaky bark peels off in long strips onto

the graves and as it decays, smaller

vegetation begins to grow in the

100 years, a forest would grow from

the graves.
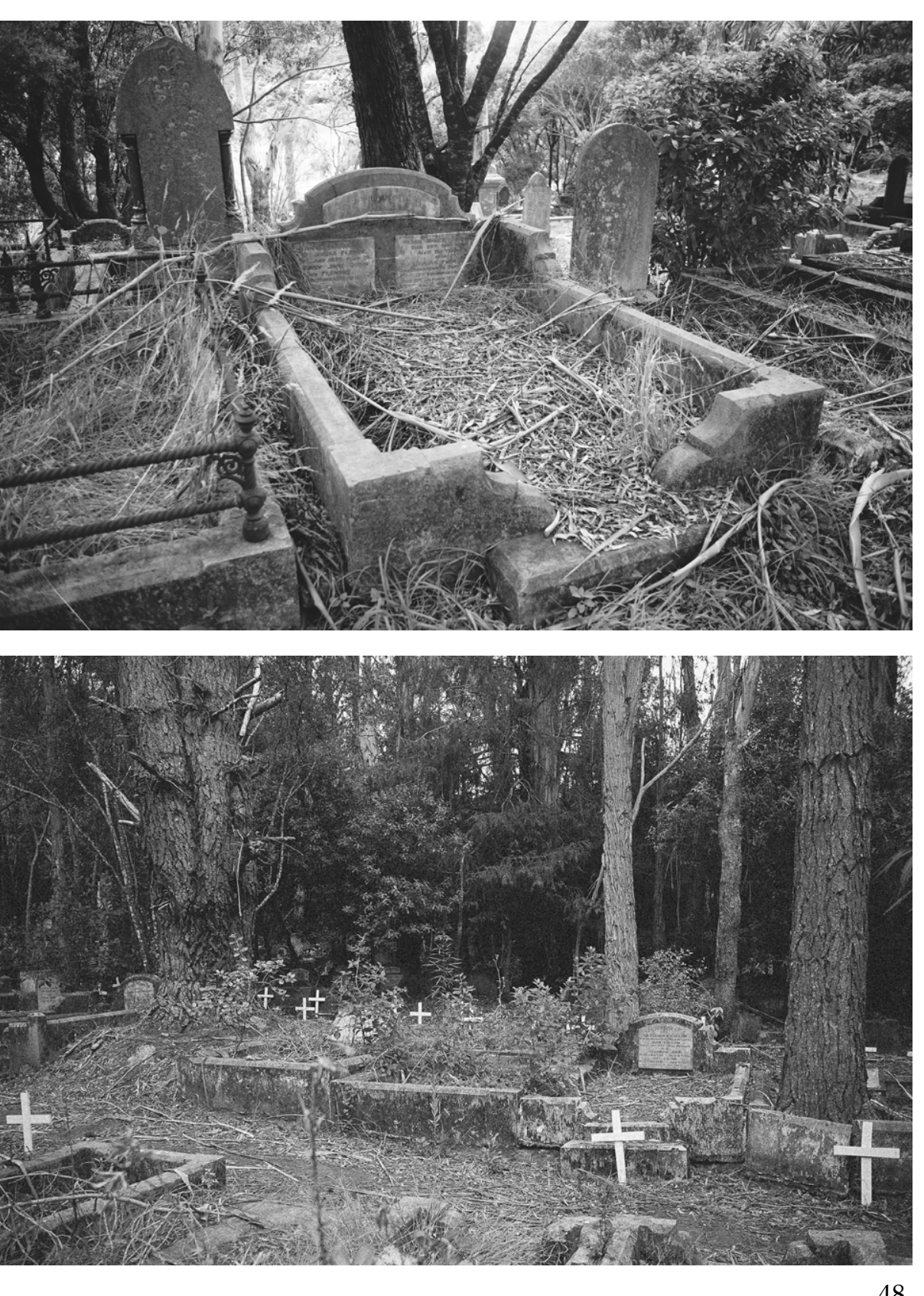

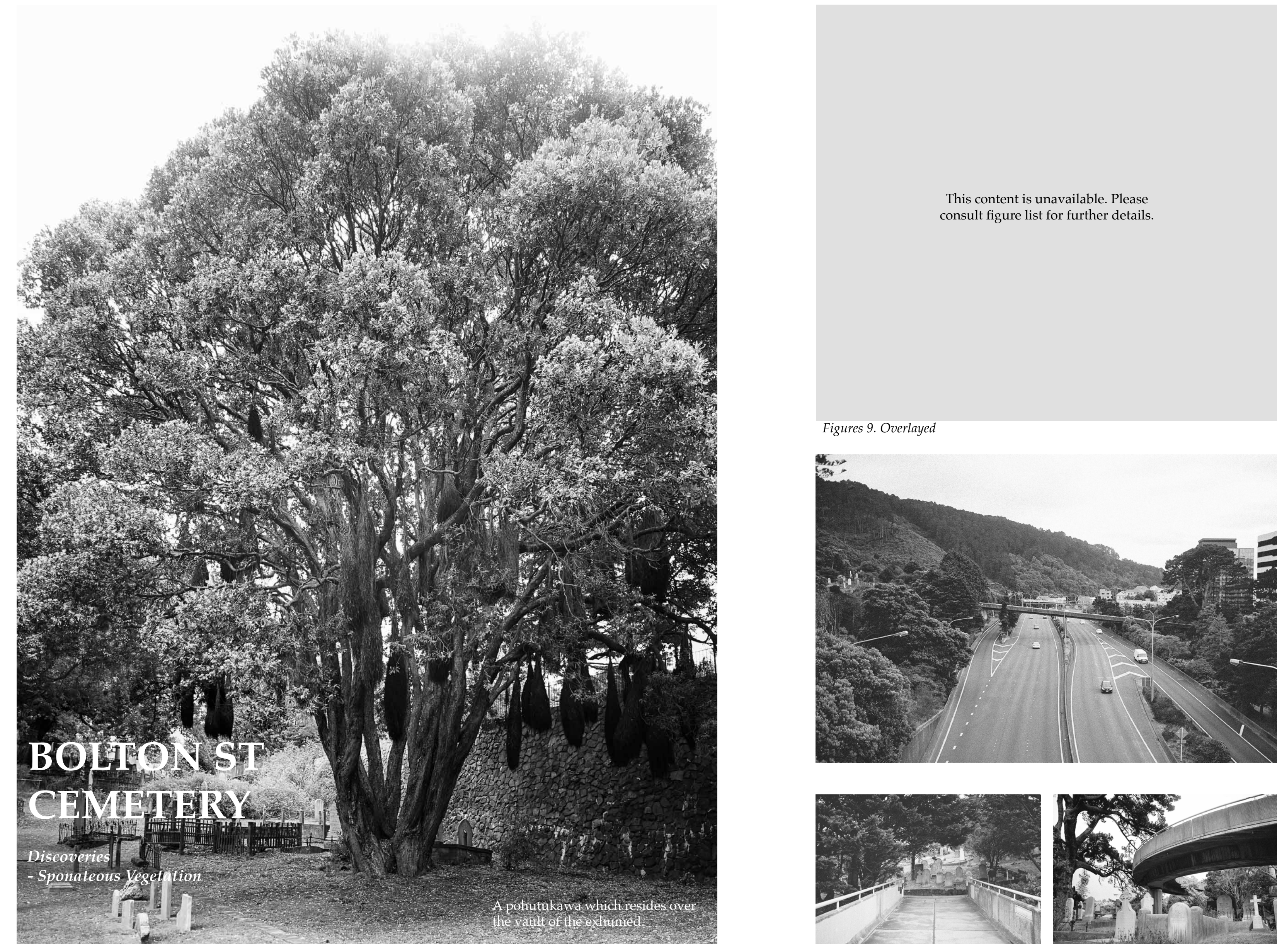

Disregard for the Dead

Bolton St Cemetery was Wellington

City's first burial ground and opened

in 1840 . It was full by 1892 . By 1960

Wellington was in need of better

access into the city. There was a

lot of controversy in the route of

Wellington's motorway. The cemetery

was in the way and from 1968 unt

cow 3,700 bu

now lie in a large sealed vault under

the bisected eastern half of the

cemetery.

There was a promise to build a

linking piazza (fig.9), but this never

eventuated and a narrow footbridge

over the motorway was constructed

instead. The overall damage to

the cemetery was considerable

and marked a turning point on

Wellington 's attitude to conservation

questions.

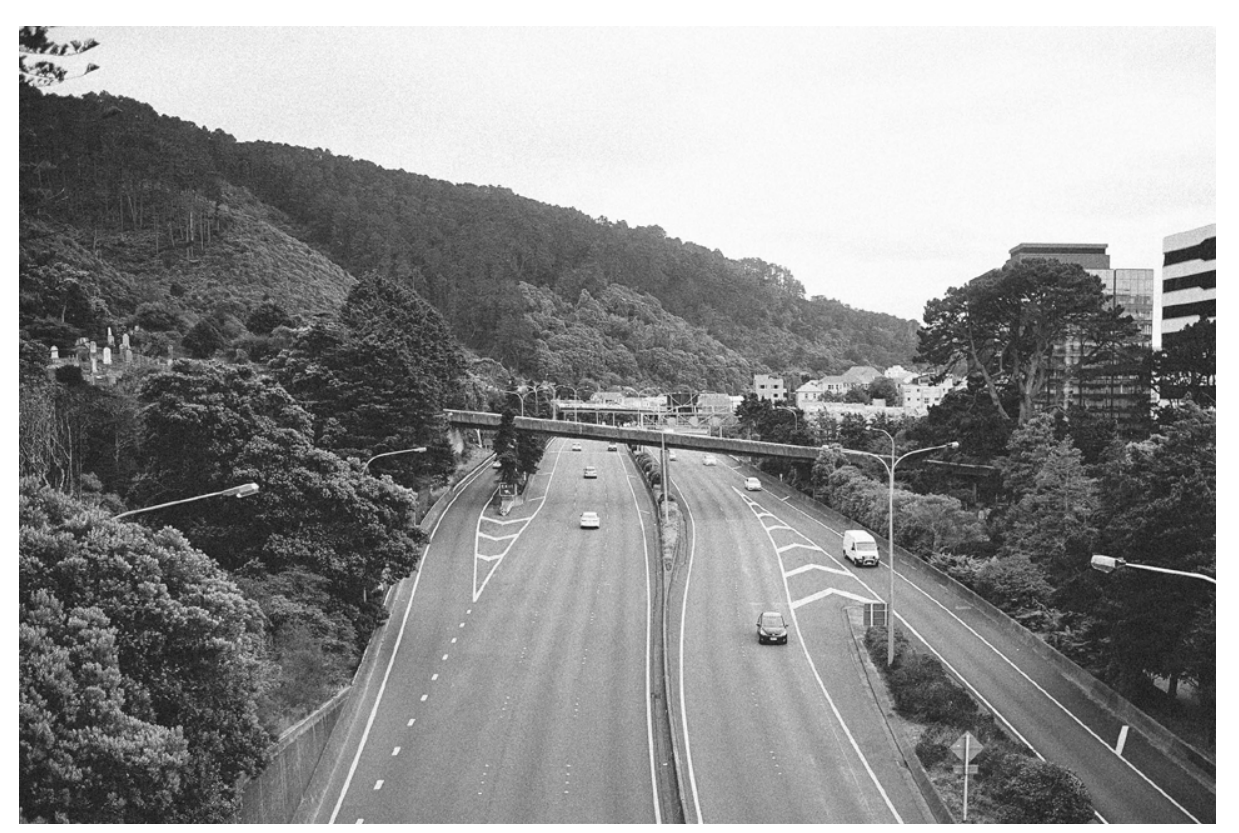

The bisected cemetery today,

showing the footbridge connecting

the halves. Thousands of

Wellingtonian's drive over the old

resting place of 4000 people a day.

Te Ahumairangi in background.
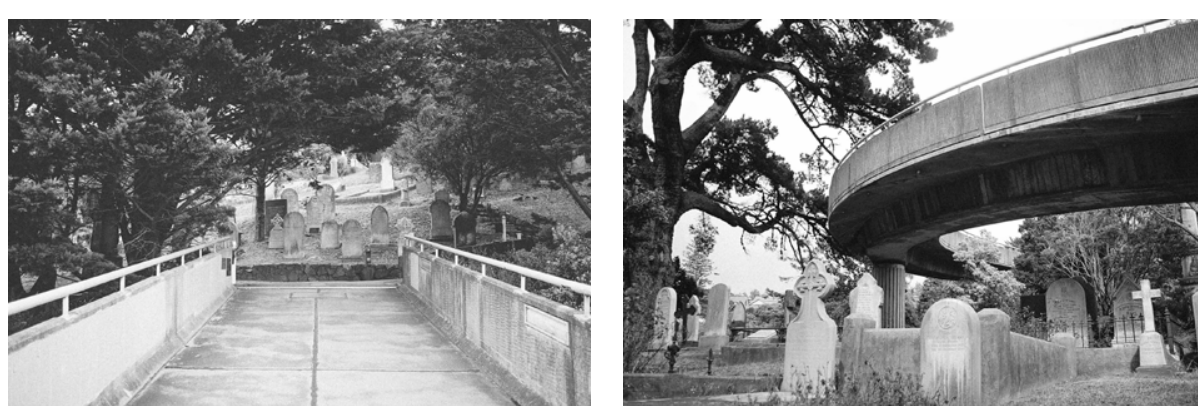
Spontaneous Flora

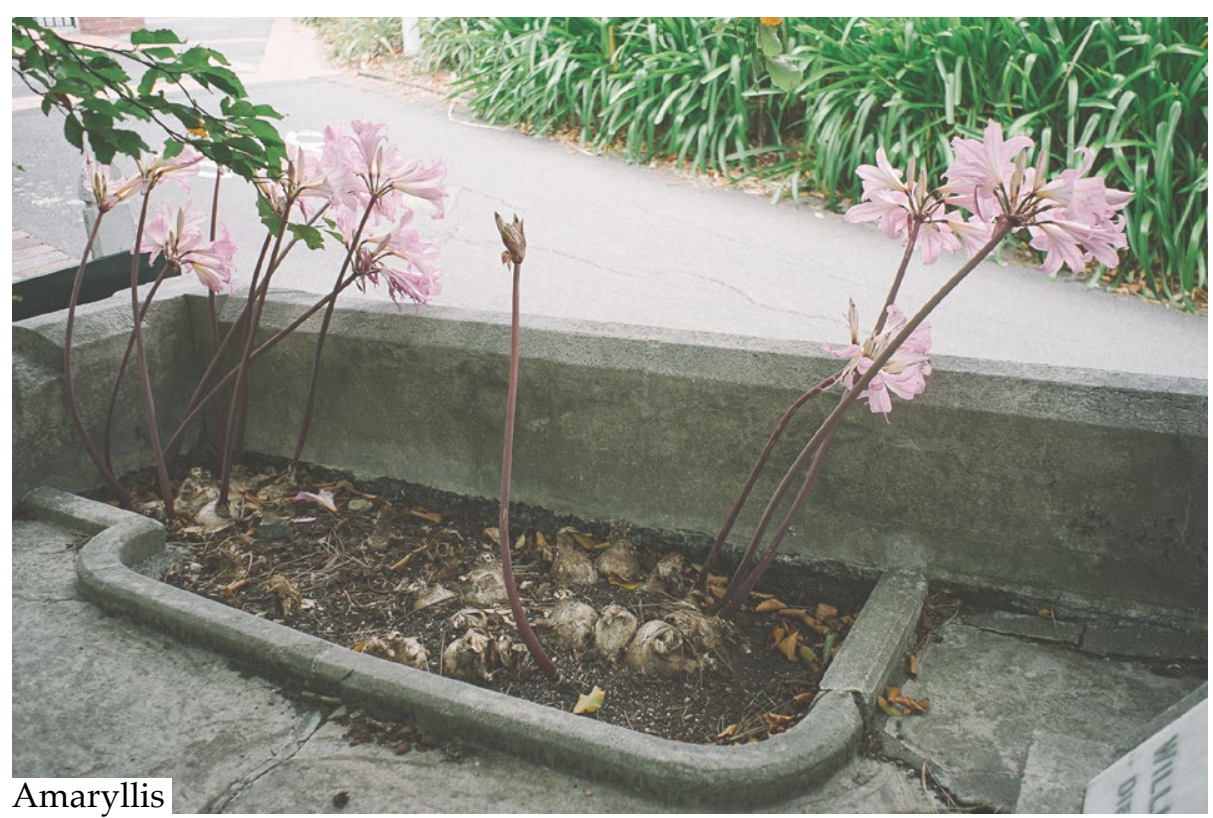

Autumn

Autumn marks the end of summer

and as the temperature cools,

Amaryllis emerges on long naked

stalks and erupt into a show of

pink blooms. They are a South

African species and like many of our

cemeteries, they thrive in the harsh

conditions.

Some of the graves are gardened,

mulch is spread and flowering

perennials are planted.

Hydrangea burst into shades of red white and purple down in the shady gullies.
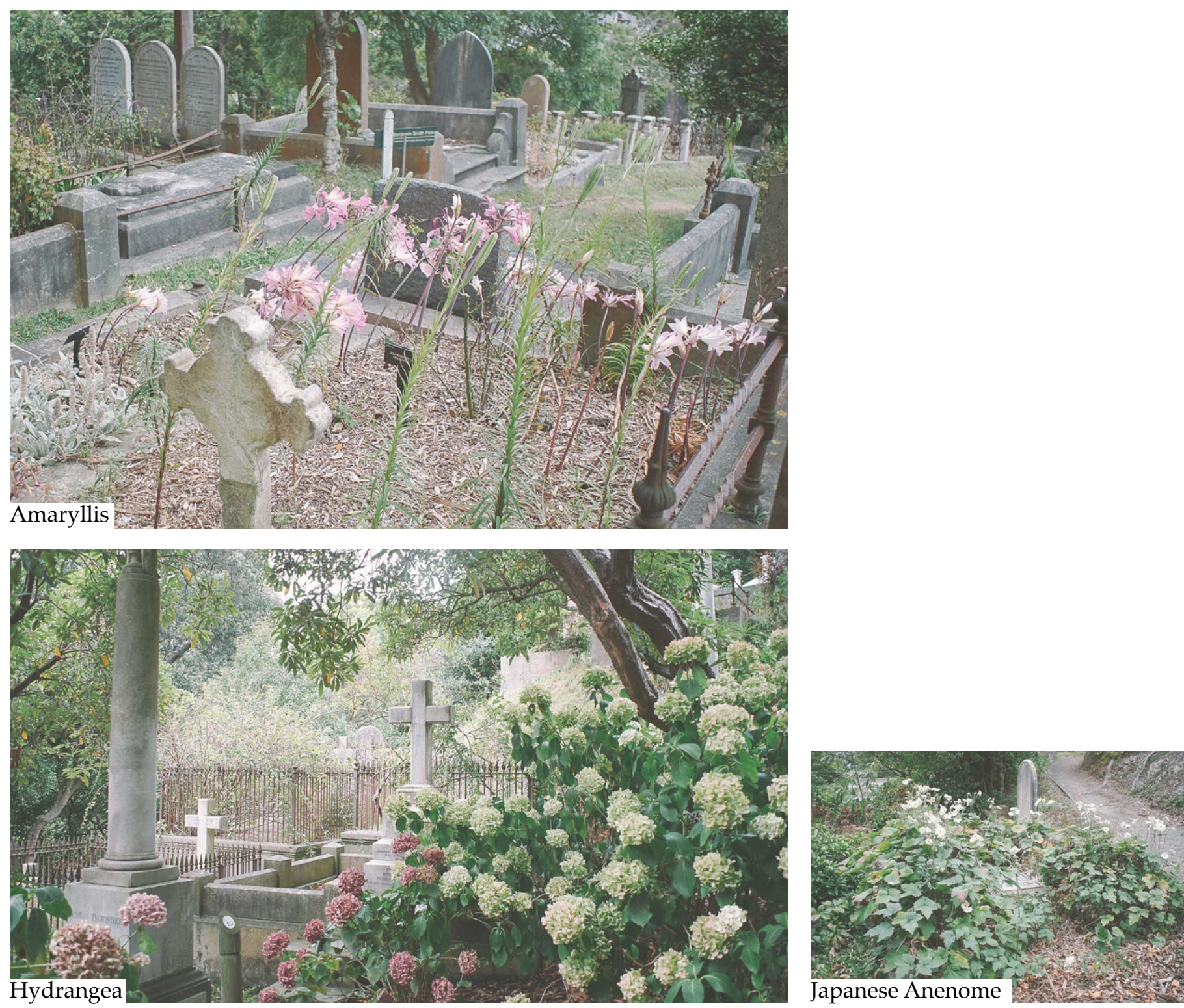

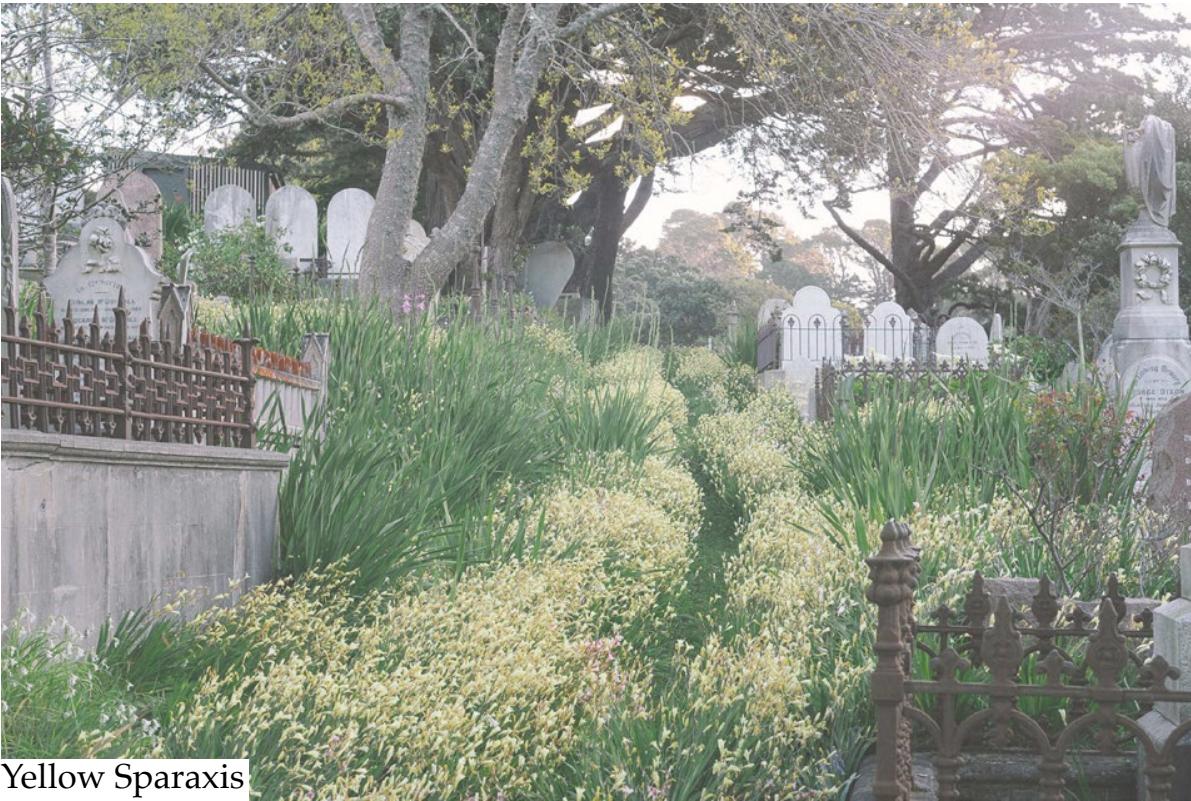

Spring

Spring brings warmth from the cold

winter, here a range of other South

African bulbous species have taken

hold. Prolific in their reproduction,

sparaxis line many of the paths in

the North Western section.
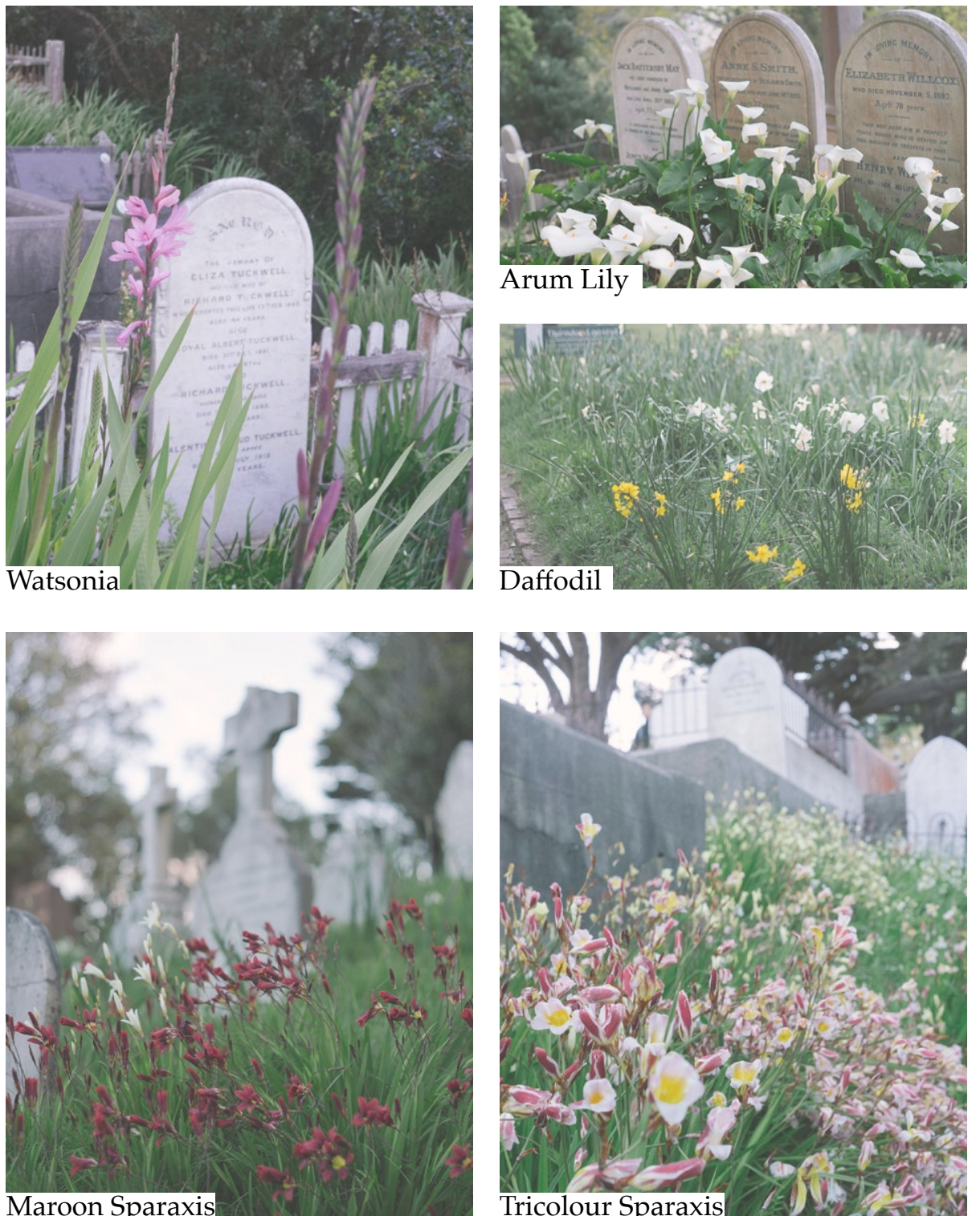


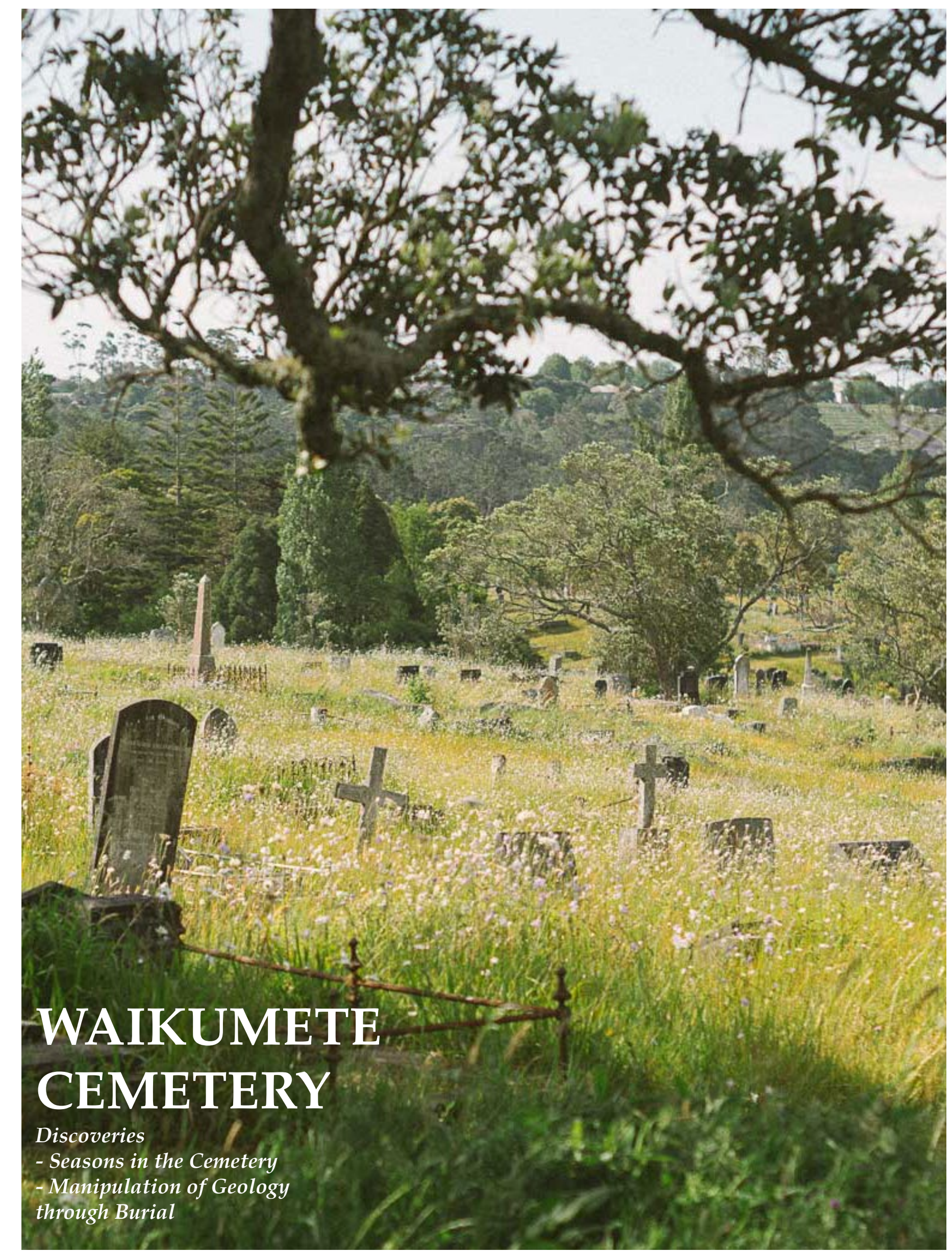

\section{REGIONAL CEMETERY STUDY}

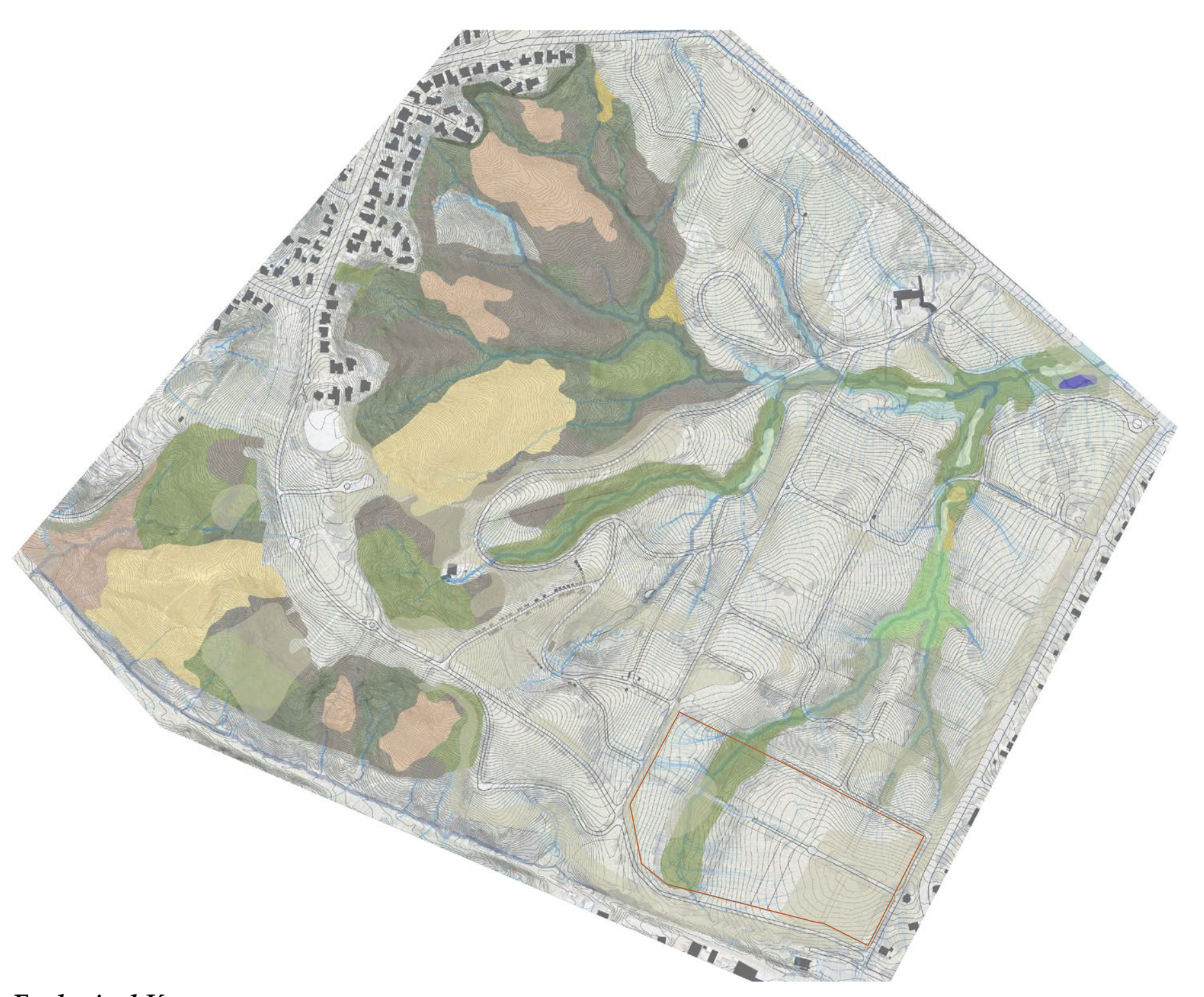

Ecological Key

Areas of Dichelachne

Gumland Heath

Native Forest/Scrub

Fire Induced Gumland

Exotic Fores

Exotic Scrub

$\square$ Wildflower Reserve 

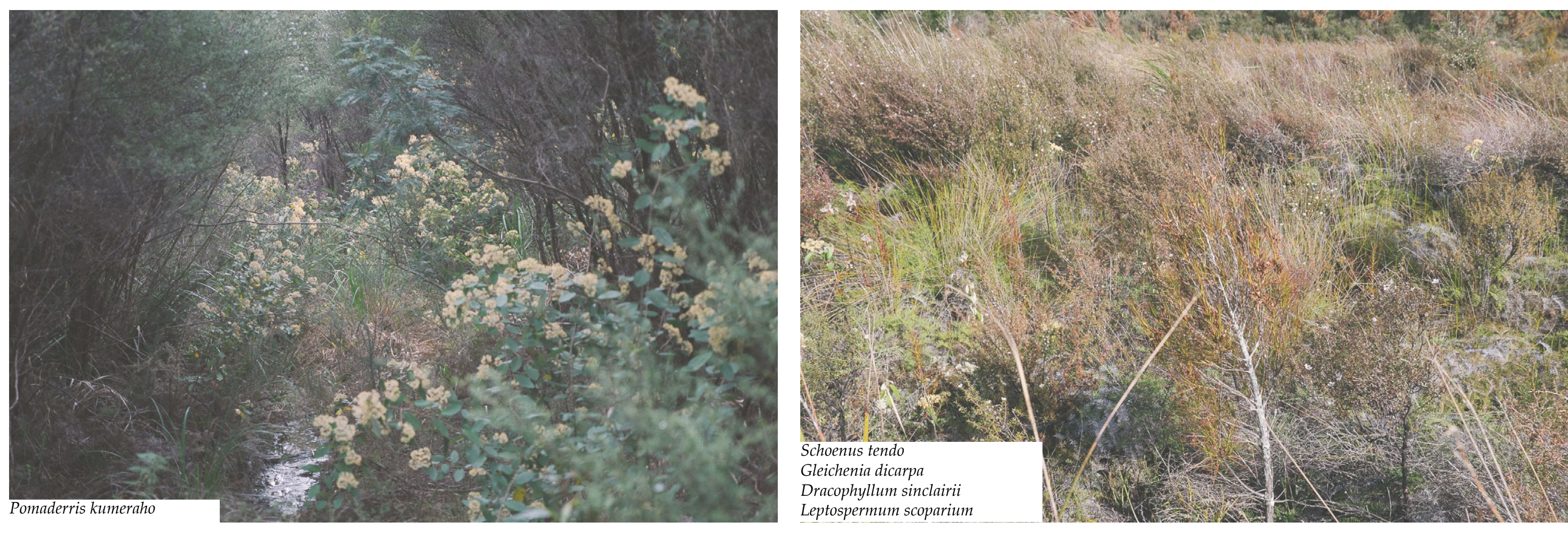

Waikumete Cemtery was a large native gumland ecology before it conversion into a cemetery. The

surface was molded into pathways,

rows and burial plots. Gumlands are

a soil and ecology associated with

kauri forest, kauri gum is preserve

in the soil conditions and hence -

gumland. The soil is generally sodde

in winter and baked dry in summer.

This results in very difficult growing

conditions and as a consequence

plants that are low-fertility tolerant,

thrive. There are small areas of this gumland left.

The Manipulation of Geology through Buria

The proccess of digging graves here has led to the soils becoming even

more infertile. The small amount of fertility left in the top layer of clay

was disturbed and mixed with the lower leached clays. When the soil was

placed back atop the deceased, very few species of plants were able to grow.

placed over such a large areal

Burial over such a thre

altered. Now the cemetery (next page).
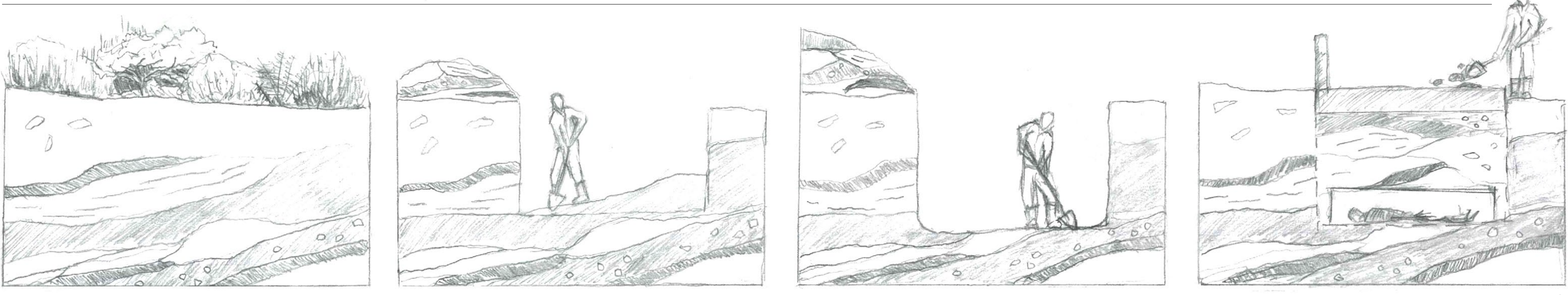

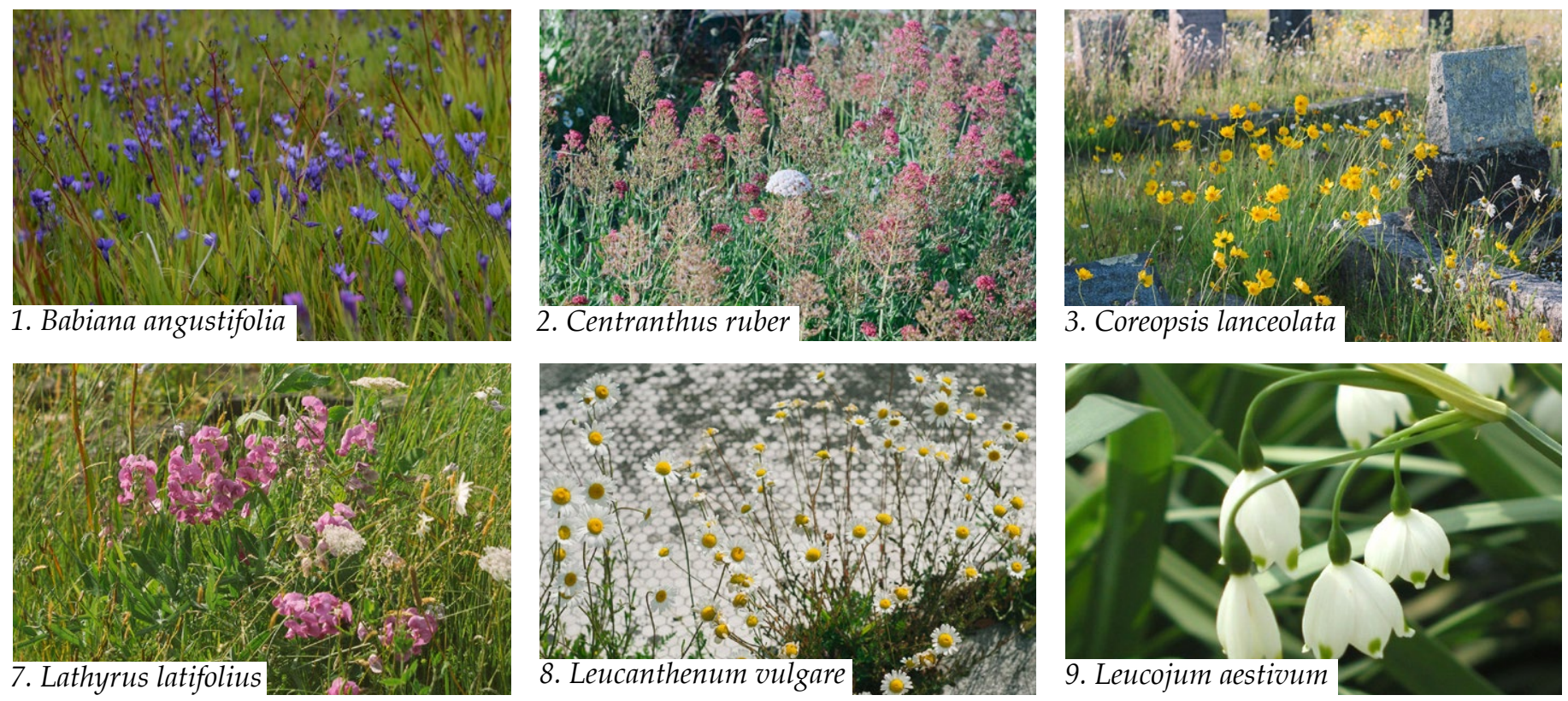

\section{Spontaneous Flora}

Waikumete Cemtery is a stunning seasonal display of largely South African flowering plants. They were planted on graves throughout the century as a token to the deceased, like one would with cut flowers. Over time as the plants have flowered, seeded or grown as a rhizome, the cemetery has morphed into a large wildflower meadow. Part of the like Watsonia. It also provides habitat for Dichelachne crinita and D. inaequiglumis which are two uncommon species of native grasses.
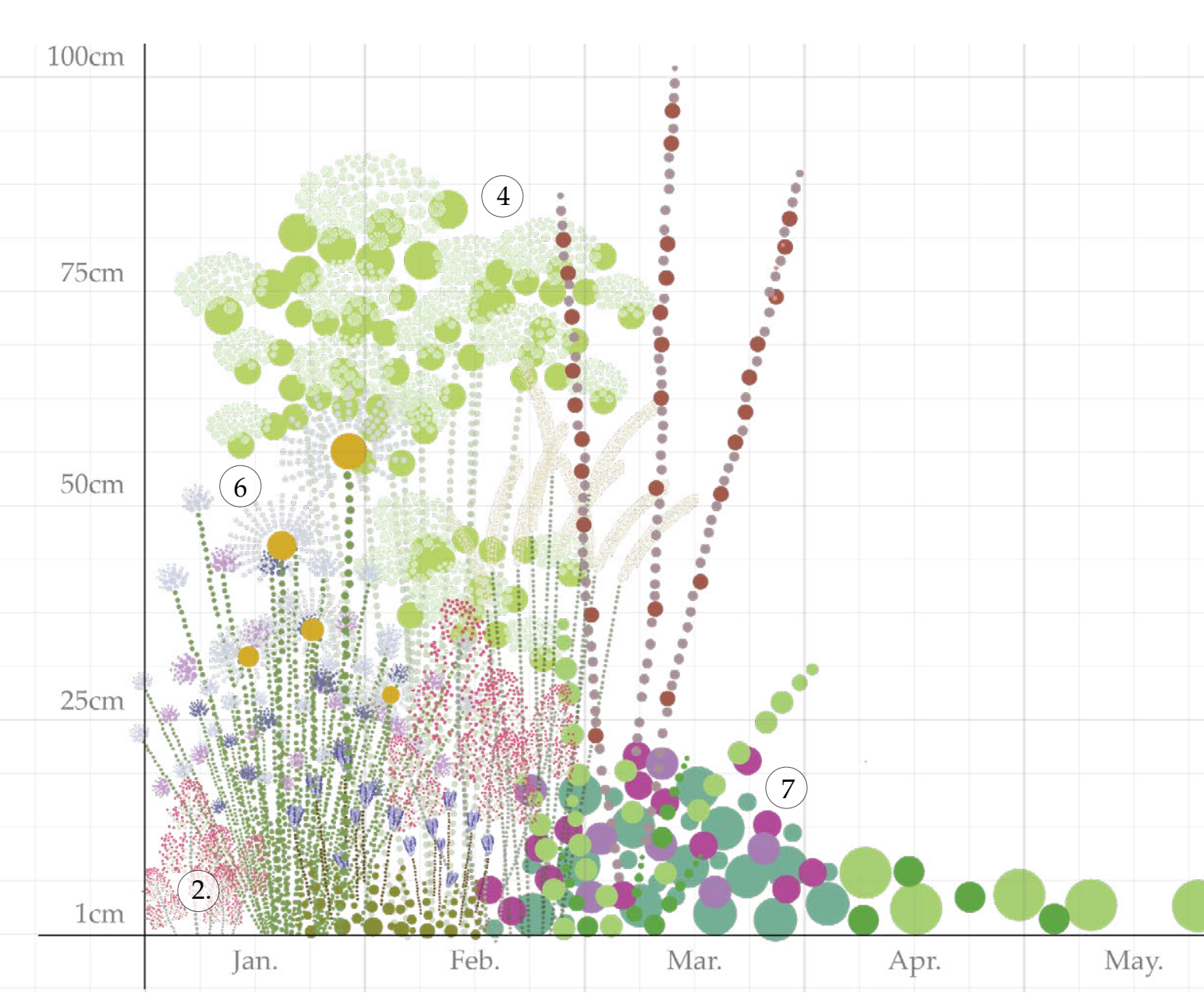
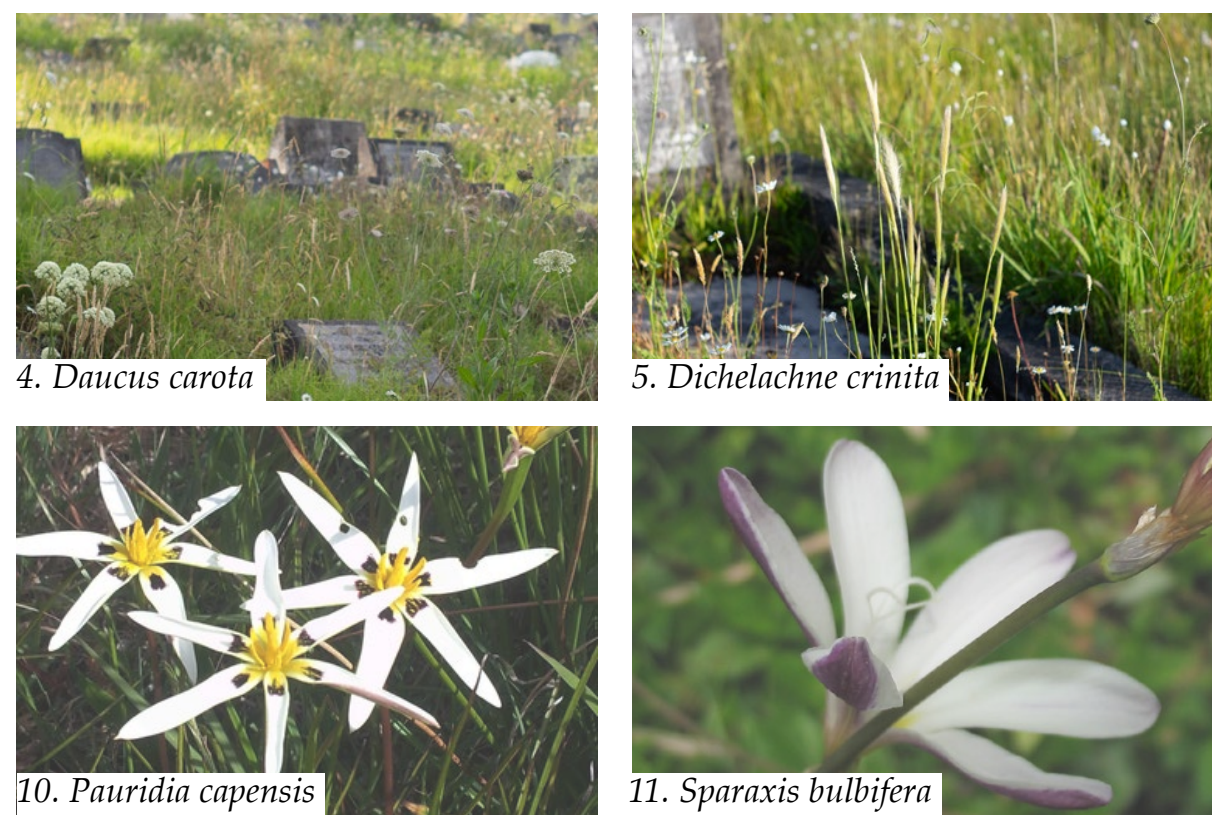

The phenology diagram below shows when the different species of flowers occur in the year, as well as height, structure and colour. Waikumete is an example of mourning loved ones, changing the ecology of a cemetery through can gring can contribute to the wider. What might be brought the forested landscape by
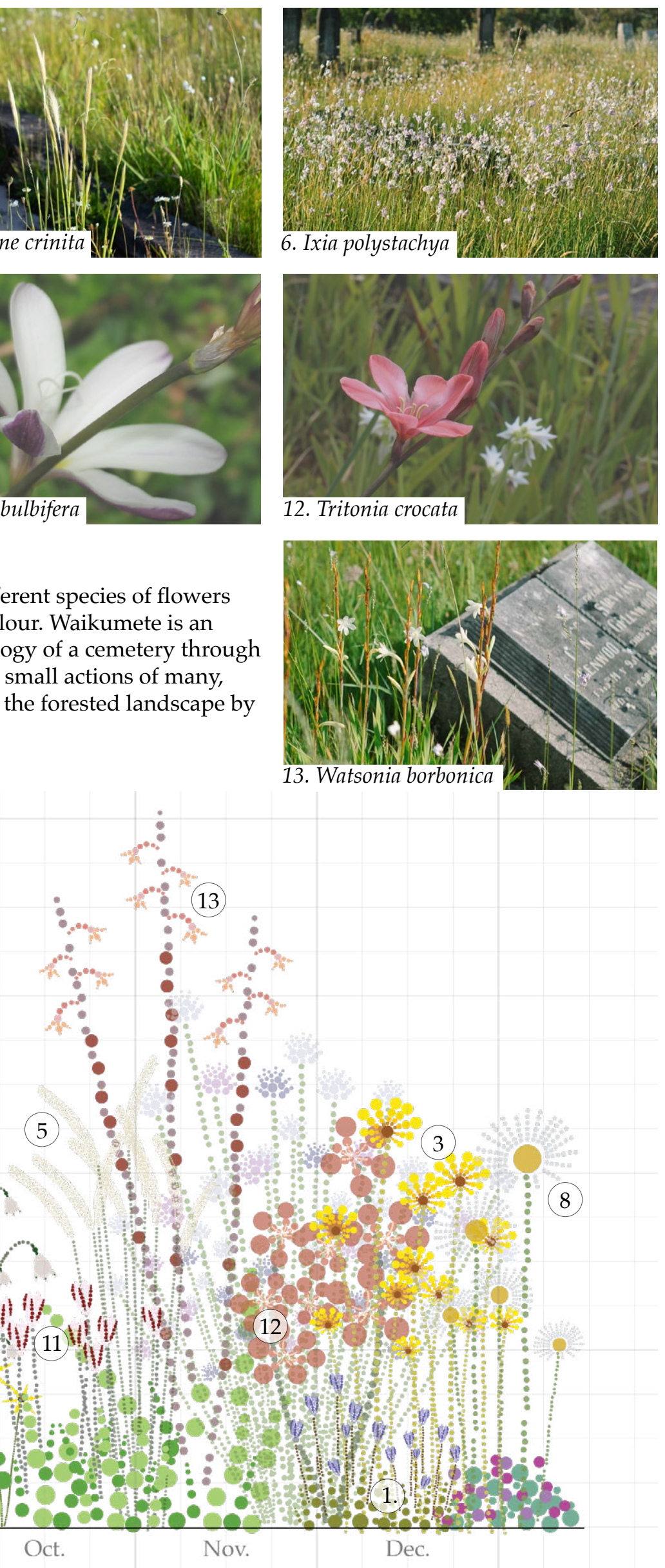


\section{International Cemeteries}




\section{Kongenshus Mindepark}

\section{The Challenges of Topography}

\section{Year - 1953}

City - Jutland, Denmark

Landscape Architect - Carl Theodor Sørensen

This content is unavailable. Please consult figure list for further details.
This content is unavailable. Please consult figure list for further details.
Kongenshus Mindepark

commemorates the early of efforts of

farmers who reclaimed the heathland

to feed the nation during the Danish

resistance whilst also celebrating

he heathland ecology. The design

distills sacred associations of

prehistoric Danish stone dolmens, the

landscapes of heath and connection

to the Ice Age glacial landscapes

of Denmark. The large boulders

are both symbolic of the glacial

movements that shift them and the

cultural manipulation of them in

marking the dead.

The design moved almost no earth, instead the topography of the narrow

glacially carved valley was utilised

to direct experience through the

memorial space. As one passes the

rows of large stones, the tall slopes of

sesonally mauve heath, block out the

surroundings and draws experience

down the valley and into the sky

above.

Sørensen was not challenged by topography and instead used

its power to create a celebrated

memorial landscape. 


\section{Skogskyrkogården}

\section{Spatiality, Arrangement and Experience of the Fores}

\section{Year - 1917}

City - Stockholm, Sweden

Landscape Architect - Sigurd Lewerentz

Architect - Gunnar Asplund relevant to the research as it is

cemetery that was created within a

existing forest.

The dark mass of pine tree

represents the original matrix of

the place. Asplund and Lewerentz

designed voids withing the forest

to allow for burial, and let light into

the forest for the experience of the

living. These voids represent one of

the earliest types of cultural lanscape

architecture, the forest glade or

clearing.

The sense of place is based on the sacred significance of this pine forest and rejects the cliché of the traditionally picturesque cemetery. The main processional path leads the eye toward the sky and directs human understanding toward its integration with natural and celestial realms. A sense of resurrection for the living. Skogskyrkogarden engages the individual and group through experience of the forest.

Similar ambitions are useful when creating a natural burial landscape within a forest. Their method of used photography and drawing for studying the potential of forest graves. A similar methodology will be tested in this research.
This content is unavailable. Please consult figure list for further details. 


\section{Middle Village Cemetery}

Year - Established 1879

City - New York, U.S.A.

Designer and intention not the focus

\section{Spontaneous Flora}

Middle Village Cemtery is located in Queens, New York. There is a curious phenomena that occurs at this cemetery, brought to my attention by Eric Oglander. Upon a walk through certain areas in the cemetery, one might come to
notice the somewhat regular scattering of mulberry trees. As a member of the Morus genus it produces elongated blackberry-like fruit. The trees appear throughout the cemetery in descending heights, they also tend to be growing right out of the headstones. They are too close to the headstones to have been planted and occur too far away to right out of the headstones. They are too close to the headstones to have been planted and occur too far away to
grow from berries to blown off larger trees. The culprits for this strange relationship between graves and trees, are birds. Up in the older trees, they feast on fruit and then fly off to roost on the warm headstones. After digesting, they deposit their meal. Over time, this has lead to a thicket of mulberries sprouting from the graves and left longer, would eventually turn to fore

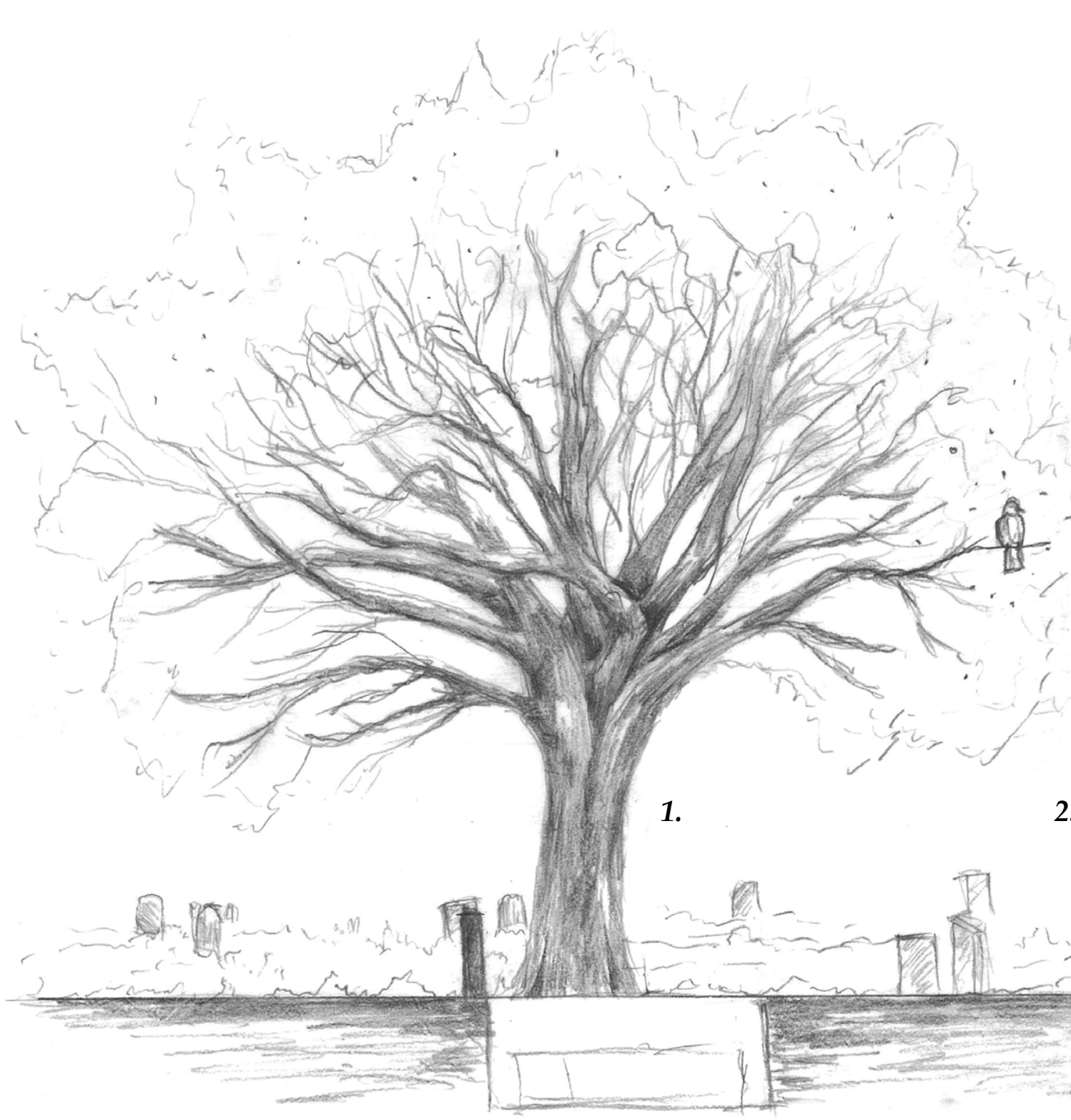

This example is an important reminder of the spontaneity brought by fauna and flora to the cemetery. How might animals form relationships with our cemetery landscapes and create novelty through their actions? By engaging with the interconnectedness of life-forms in the landscape, we can provide the right conditions for them to flourish. In turn, this shapes our experience of cemeteries and allows our dead to interact with the

This content is unavailable. Please consult figure list for further details. 


\section{Chapter Four - Site Selection:}

Current Practice
Criteria
1.
$\begin{array}{r}\text { Land zoned outside } \\ \text { of the rural-urban } \\ \text { boundary. }\end{array}$
2.
Flat-gently sloping
gradient; well-
draining soil
with minimum
groundwater impact.
3.
30 minute drive of
most residents.

4.
Located on public
transport routes, near
a main highway.

My Site Criteria

1.

Use government owned reserves (no purchase cost, lower burial prices, most are already used for recreation).

2. Ability to accommodate alternative burial (allows for steeper and forested land).

3. Within walking distance of Central Business District (close to daily life and sociality).

4. A site with native afforestation aspirations (burial can fund and enhance ecology). 


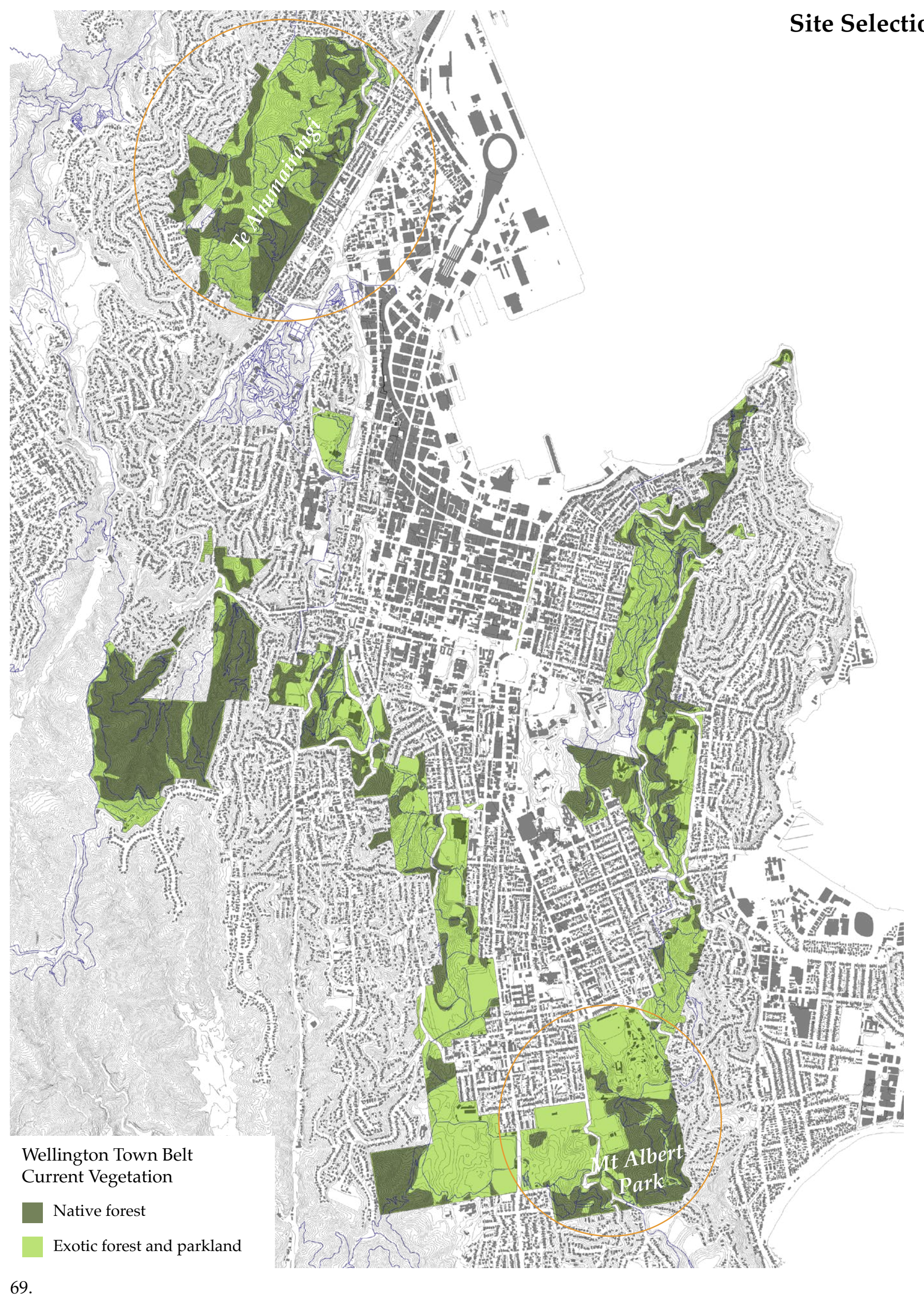

Town Belt Management Plan

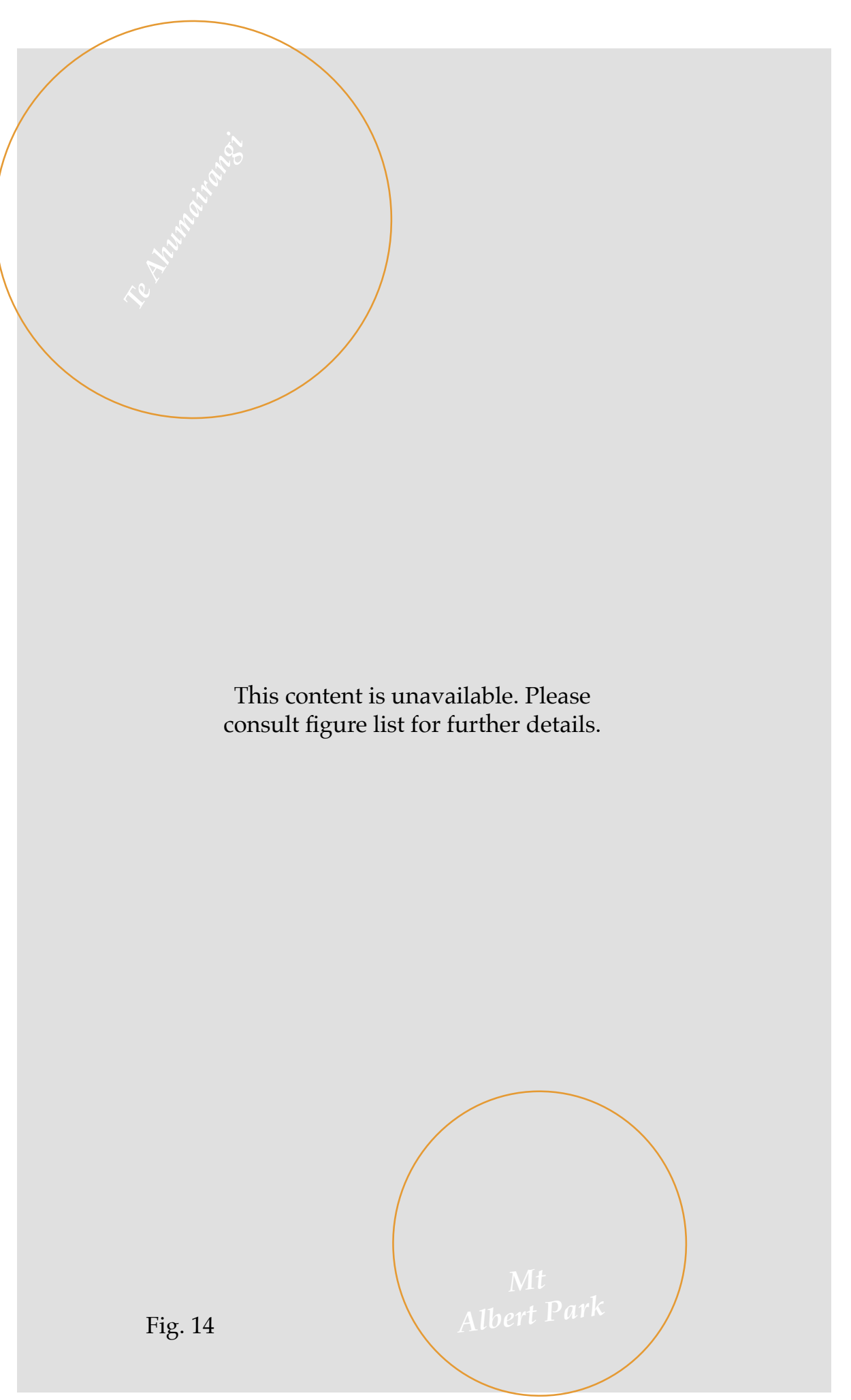

reserves in the Town Belt have large areas of actively managed exotic forest such as Mount Victoria. Mt Albert Park and Te Ahumairangi have a long-term ambition of native afforestation.

Mt Albert Park is the second best option based on the site criteria. But, thes $3 \mathrm{~km}$ from Cuba St and would be deemed to far to walk for many.

Te Ahumairangi is four times as large as Mt Albert Park and could provide a large enough area for ongoing the CBD and 30 minutes from Cuba St. It provides a green backdrop to St. It provides a green backdrop to
much of the city and a cemetery here has the potential to change the way the city relates to the Town Belt. It currently acts as a topographical but the design of the cemetery has potential to create better acess between the city and suburbs.

\section{Wellington Town Belt} Proposed Vegetation

\section{Conifers}

Exotic forest and amenity planting

Mixed conifer and eucalypts

Grass parkland

Native vegetation - aiming to achieve maturity 


\section{Site Analysis:}


(2)

This content is unavailable. Please consult figure list for further details.
This content is unavailable. Please consult figure list for further details.
1912

Fig 20.

Wellington from the Tinakori Hills
1839

Charles Heaphy first viewed Tinakori Hill, the slopes and summit were

"densely timbered... the rata being conspicuous". Native gardens were present at the base of the hill $(1,2)$. By
and been replaced by pasture grasses.

(n)

\section{6}

Northern end of Lambton Quay.

Photographed from a vessel in the

inner harbour. Forest toward the top

ill remain

Fig 17.

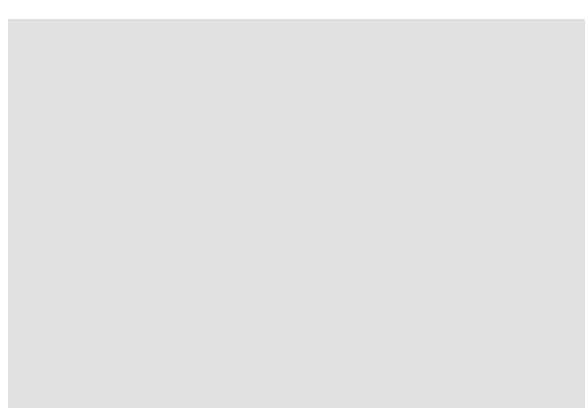

1880

Sir Julius Vogel's addition to Premie

House. Which turned the prime

ministers residence into a two-

storeyed structure. Pasture has take

hold on most of the hill. Farmlan

fences visible behind.

Fig 18

\section{4}

View over Thorndon from the Bolto Street Cemetery looking towards the Tinakori Hill. Regeneration starting to occur on farmland.

Fig 19

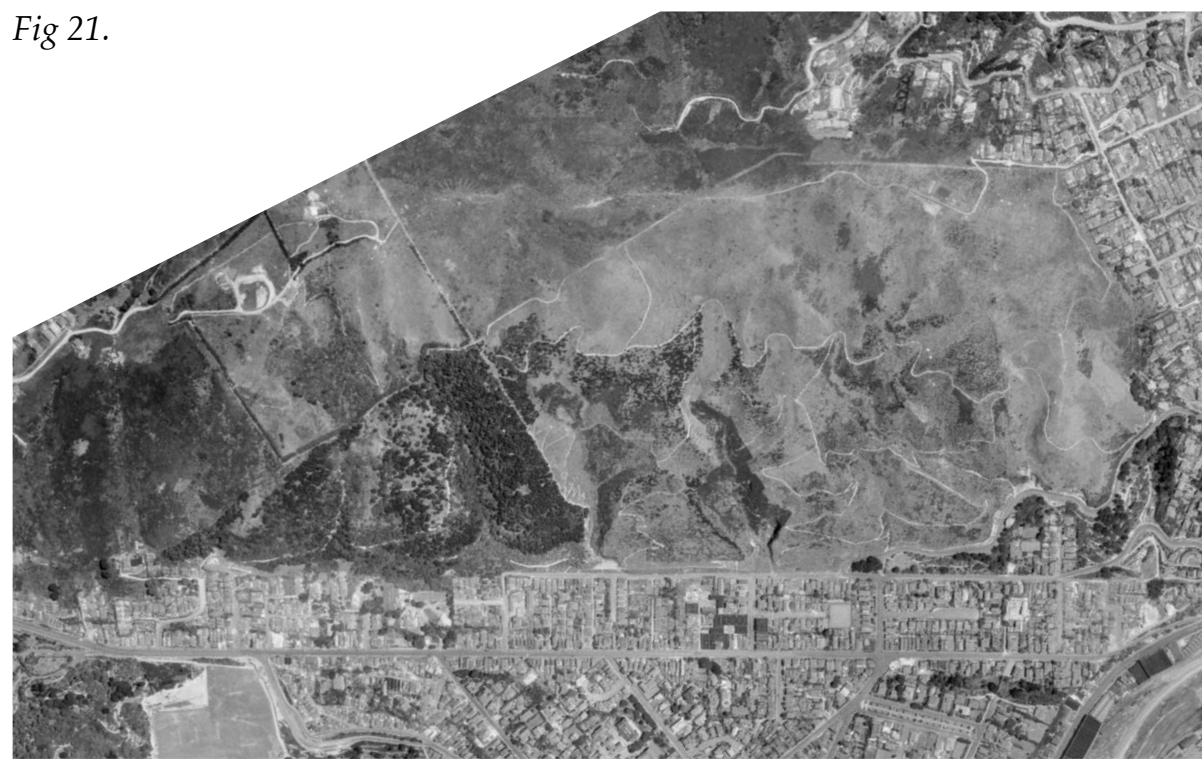

Te Ahumairangi - 1938

After thirty years of deforestion and grazing, planting work began in the 1880 s on the mostly bare hill. Conifer plantations were established around the northern end of Tinakori Hill including the oaks in Queen's Park which are now of great size. At the southern end of Tinakori hill, pine and macrocarpa were heavily planted. Other exotic species were trialled such as: gums, wattles, sweet chestnut and sycamore. Native species like pohutukawa, karo and griselinia were used extensively. Many of the paths still functional today are visible without the canopy.

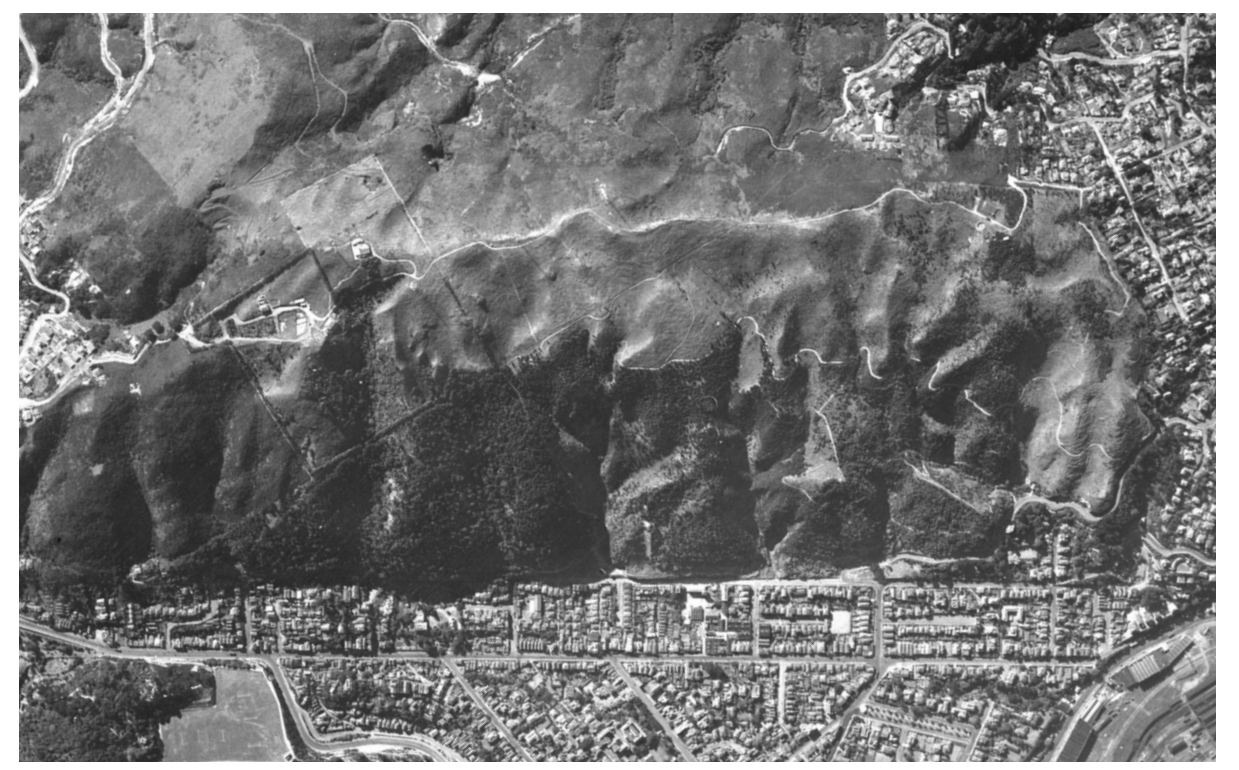

Te Ahumairangi - 1941

An interesting mixture of native species growing on the central slopes of Tinakori Hill probably dates from this time. This planting includes: rimu, black beech, black-red beech kawaka tanekaha mangaeo, and . were completed between 1920 and 1940. Pohutukawa was often planted at the edge of plantations and blocks of gums were grown on the lower slopes of Tinakori Hill. 


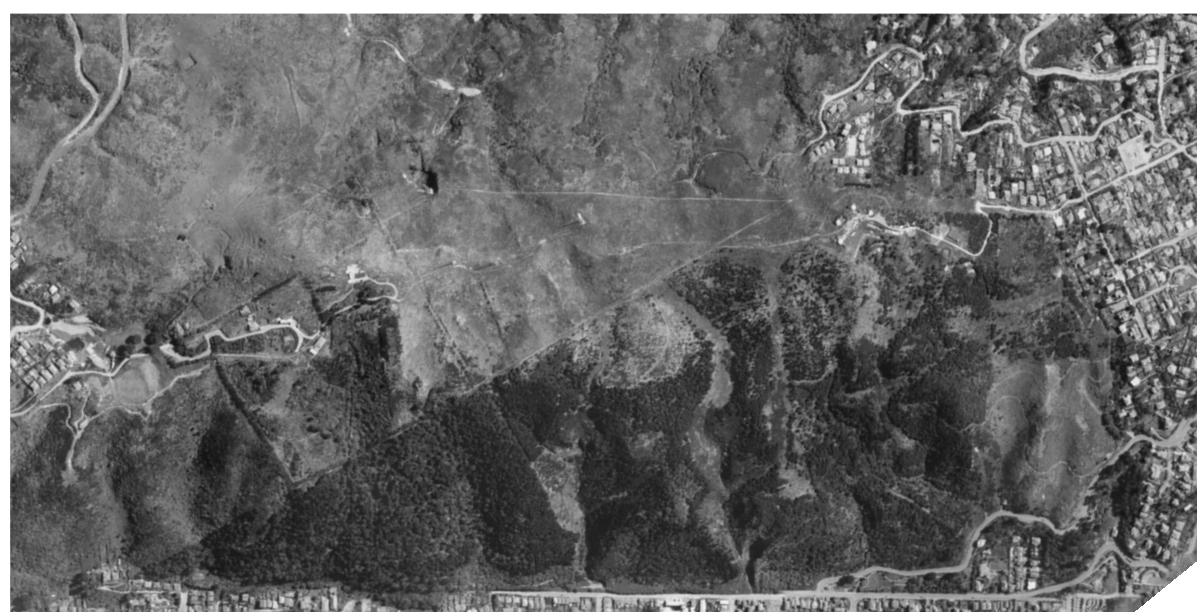

4.

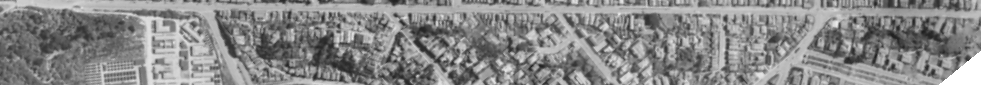
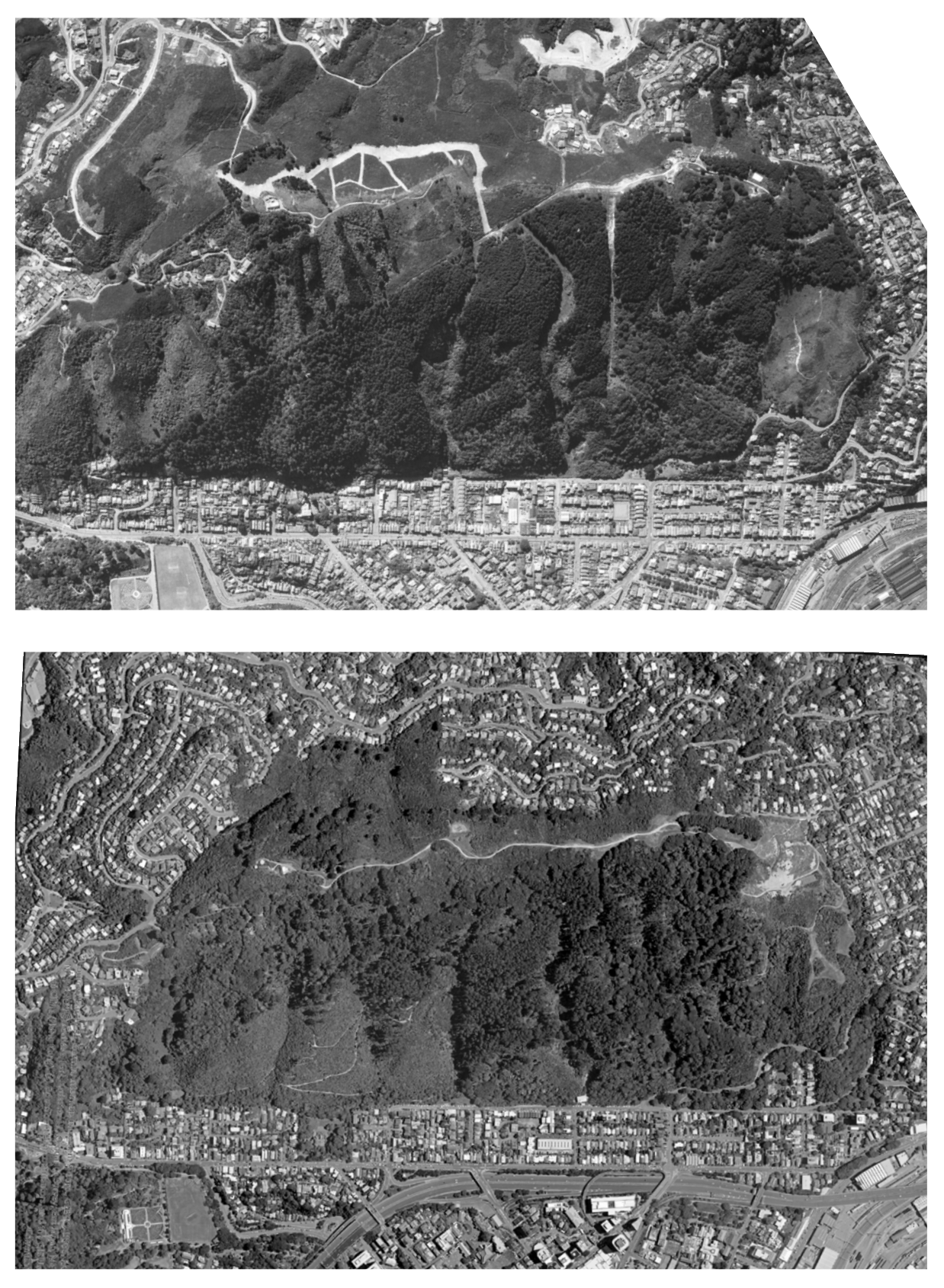

Te Ahumairangi - 2017

The landscape of Te Ahumairan phes still remain 100 years since their planting. Significant portions of pine fell over in the 2004 storm and their future as limited as they becom even more susceptible to windfall. Urbanisation has steadily encroached and SH1 has bisected Tinakori and Thorndon, severing easy pedestrian access to Te Ahumairangi.

and Cecil, Euston and Pembroke Roads are can be seen in construction. This would later open up the weste
slopes for subdivision. The conifer plantations are now beginning to

Some subdivision and new housing is visible and the Orangi-kaupapa Māori pa site and would later have has slowly been regenerating. The

\section{HISTORY}

Mining

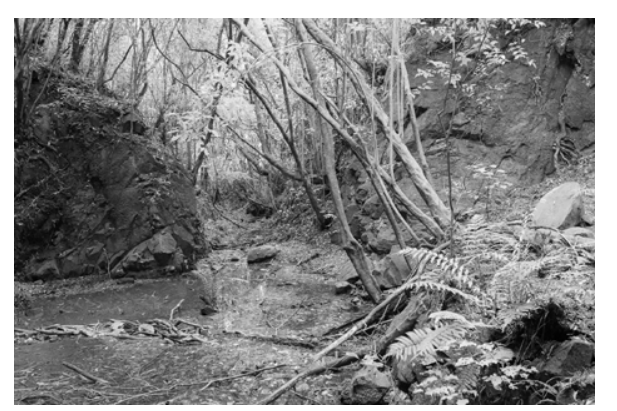

Kohatu Quarry

he Kohatu quarry is off the

Huntingdon Street track. George

homas who owned the land built

The

the quarry which enabled road meta

to removed from the site, initially by

worse and cart and later by tramway

which is still visible today.

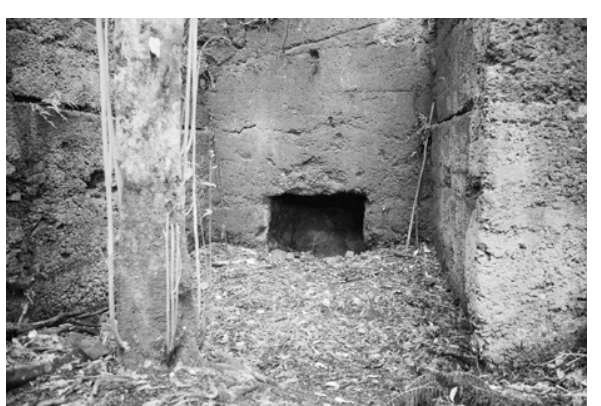

1908, he sold the quarry to Kohat uarrying Company. Following the death of the quarry foreman in an war years, the Kohatu Company wappreached the Council 1919 a affering to sell their land including

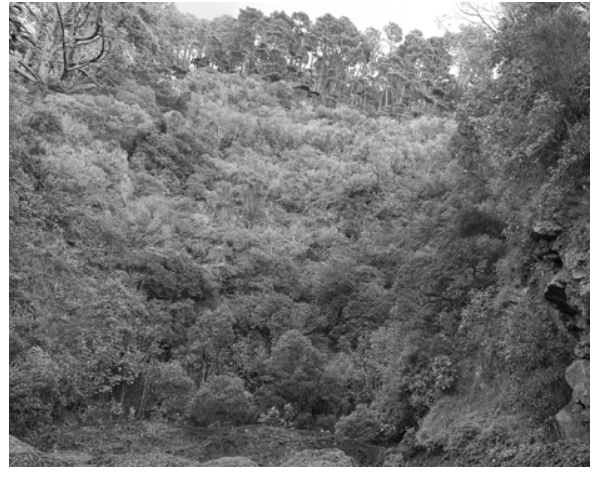

Grant Rd Lower Quarry The Grant Road quarry was Council managed and dates back to 1889 as a road metal supply. The enormous scar has grown over. It is located behind the Wellington's Potter Association. The geology of the hill is comprised of greywacke.

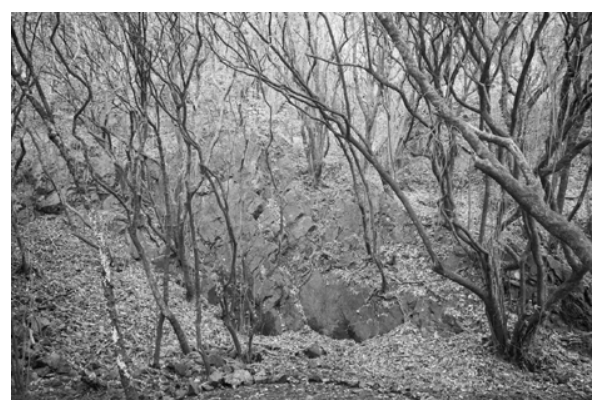

Grant Rd Upper Quarry sources of quality metal led prospecting above the existing quarry. The Council found 'a valuable source of supply' and installed wooden chutes and a cablecar system to carry the quarried rock down to Grant Road.

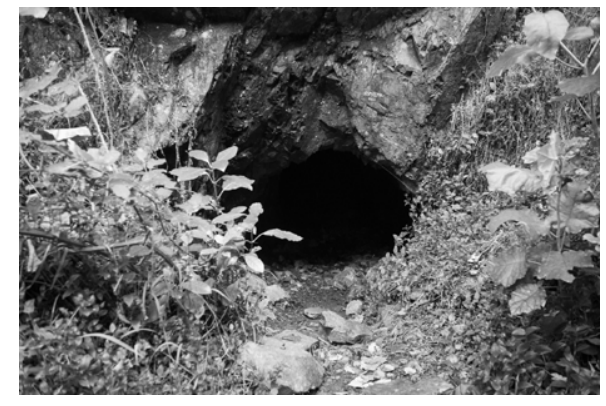

d quarry remains an enigma an

may have been part of other gold

prospecting efforts. Today it is hom

to glow-worms and cave weta.

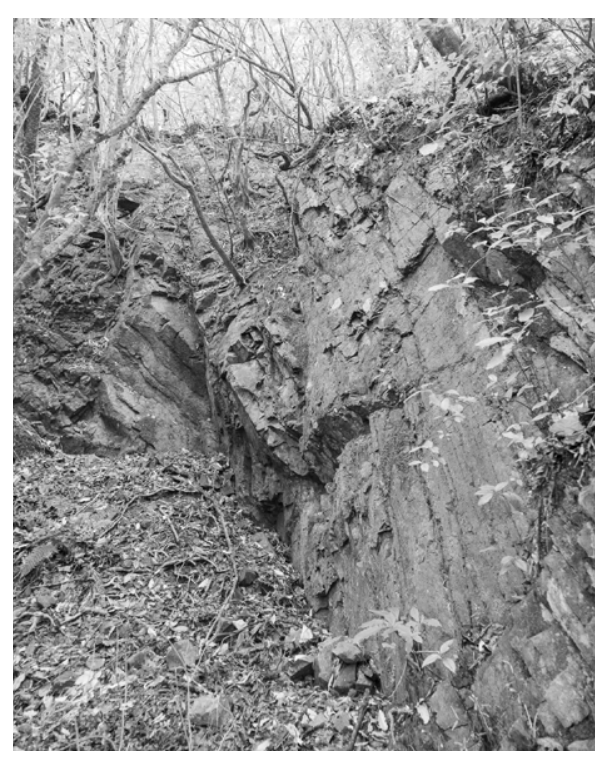

Gold Prospecting

A range of small excavations were made on the reserve near the Glamorgan St entrance. 


\section{Human Vectors}




\section{Pedestrian Catchments}
$<5$ mintues
( 5 -10 mintues
10-15 mintues
15-20 mintues
20-25 mintues
25-30 mintues
30-35 mintues
35-40 mintues

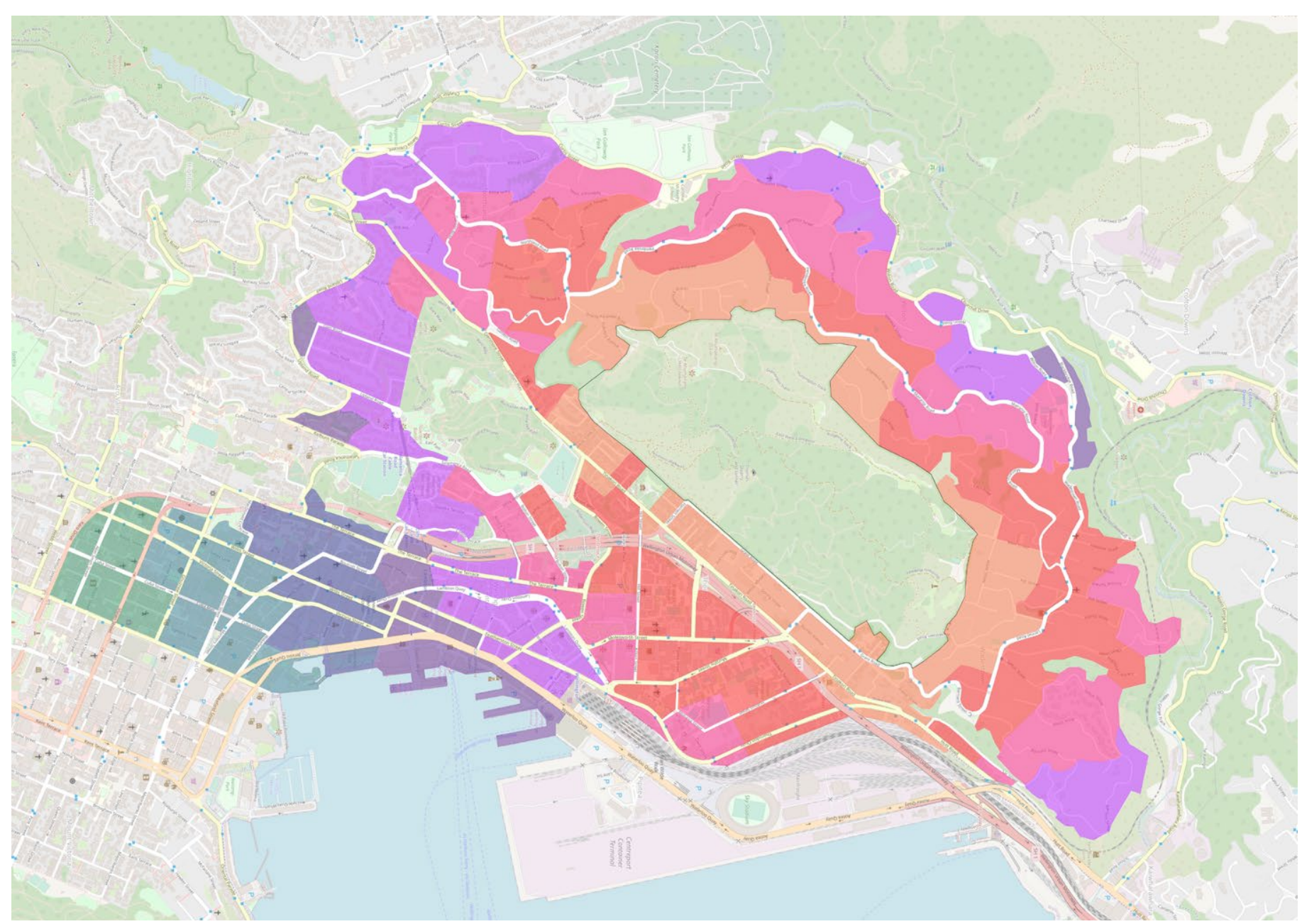

A study of the surrounding context was undertaken using Tarana

Curtis St, Wilton Rd and Churchill

Dr as a boundary. This captures

Dr as a boundary. This captures
the likely vectors from Te Aro,

Kelburn, Northland, Wadestown and Thorndon.

The times were based on walking

speed and the closest entrance to Te

Ahumairangi at any given point in

the surrounding suburbs.

Western Wadestown and the lower slopes of Northland suffer from the lack of a close entrance, despite their close proximity to the reserve.

\section{Properties that Border}

A map was constructed to

borders publicre private land

public porosity and accessibility of

public porosity a

It also shows that Tinakori and

Wadestown have the highest density

of residents surrounding, which tend

to have a greater social influence on

the reserve.

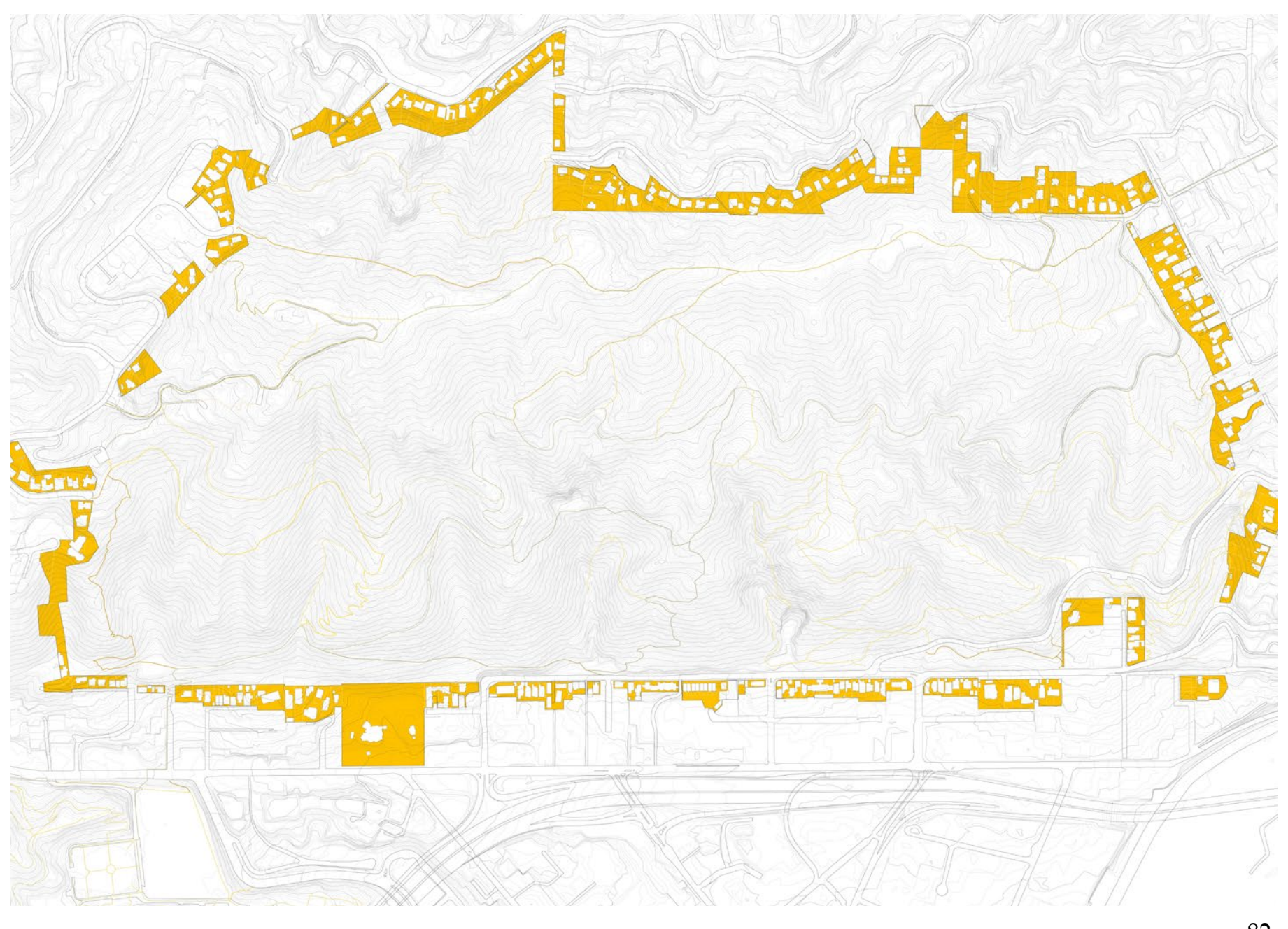




\section{Human Vectors}

Routes Taken and Desires

Tourists

Desires: Mild walking, a memento, panoramic

photographs.

Requirements: Toilets, Nature, Seating

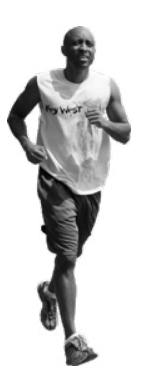

Walkers/Runners

Age: 20-50

Desire to complete a loop.

Requirements: Nature, Loop Track

\section{Cycling Commuters}

Age: $30-45$

Desires: Can take a slightly longer and exciting route to

work in Thordon or CBD

Requirements: Well-graded and dry track

\section{Dog Walkers}

Age: 30-60

Desires: Expansive grass, to throw objects for their furry

friends.

Requirements: Fresh water, Grass, A place to put dog poo.

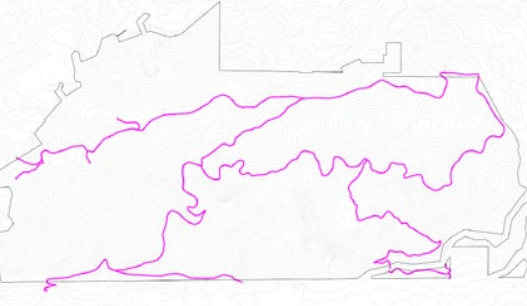

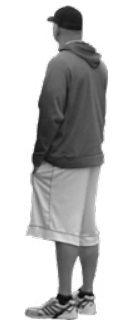
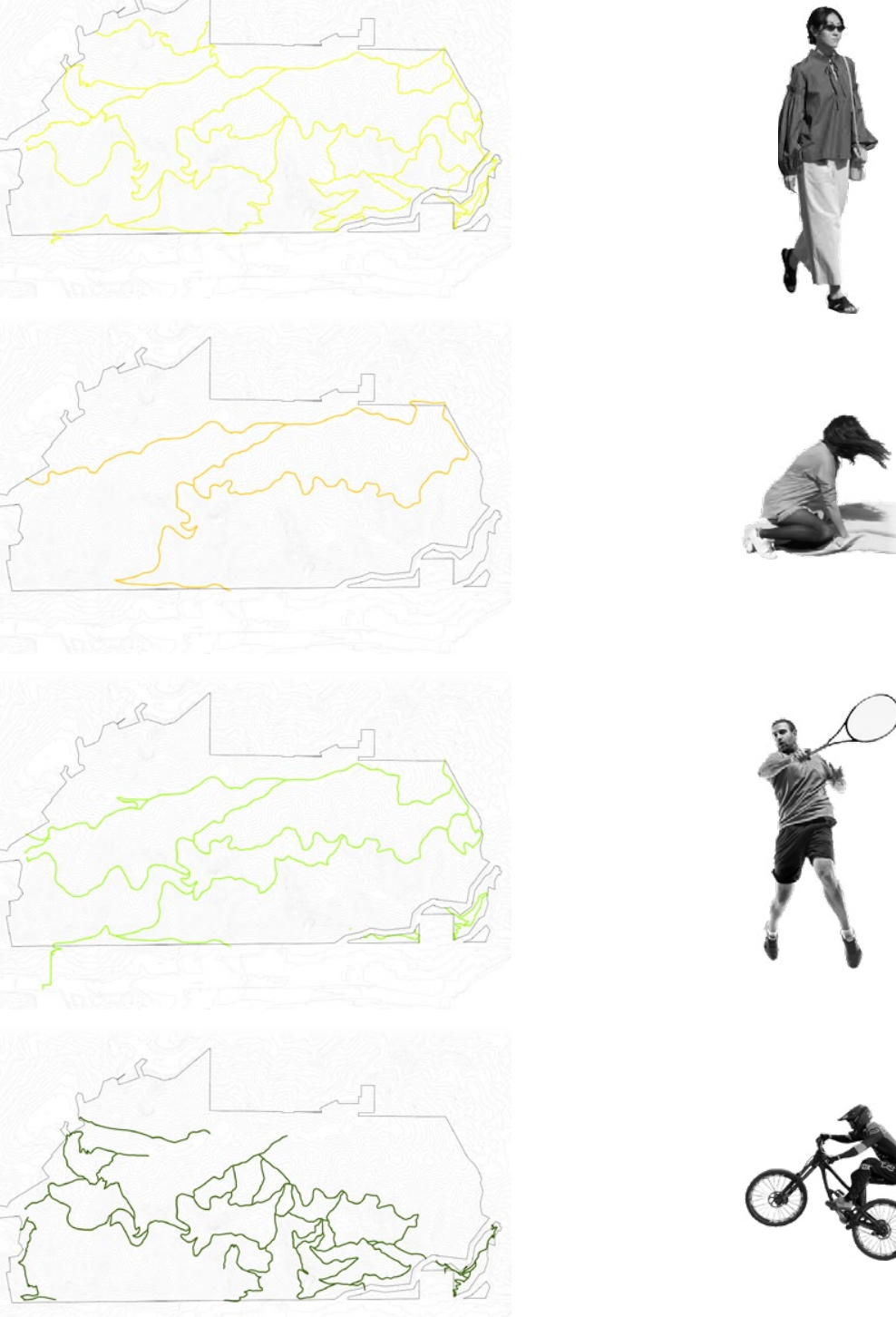

0 हैं?

Desires: Mushrooms and other wild edibles, quiet, privacy, to go off track.

Requirements: Pine or Deciduous Forest

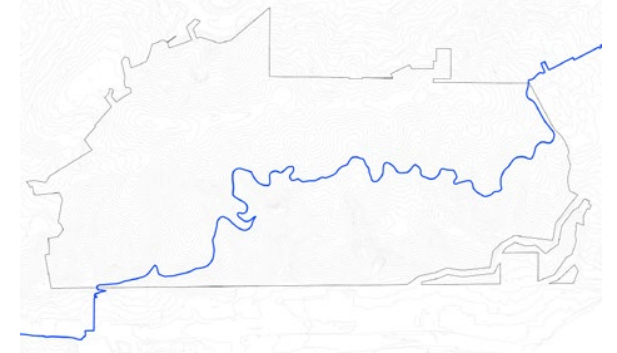
can drive places others can't. A place to have smoko.
Park-ups

Age: 18-30 rink alcohol in the car, with a view, with loud music.

Requirements: Nature, Night-time access, Carparks.

\section{Walking Commuters}

Age: 25-55

route to work in Thordon or CBD, wants to arrive clean.

Requirements: Well-graded track, Direct route, Sense of Safety

\section{Picnickers}

Age: $30-55$

Desiens, Quie

Requirements: Grass, Tables, Seating, Nature, Toilet

\section{Tennis Players}

Age: 25-60

Desires: Shelter from the wind and a short walk.

Requirements: Tennis Court

Mountain Bikers

Age: $18-45$

Adrenaline, to build their own tracks
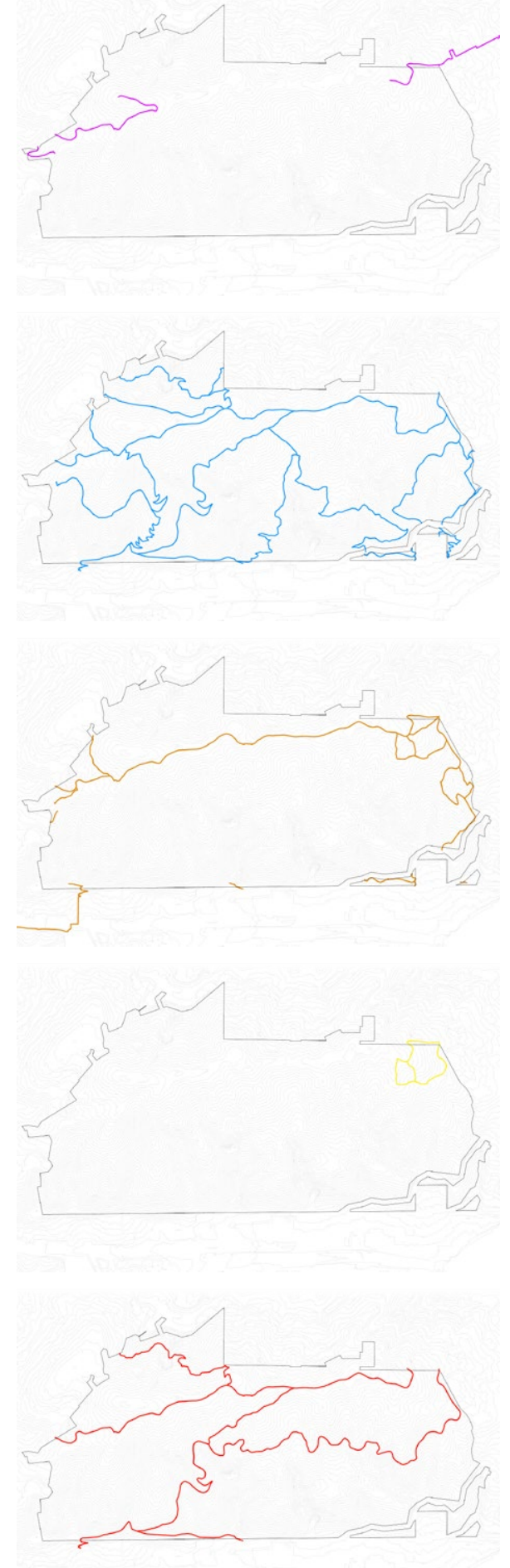

\section{Council Workers}

Age: $25-50$

Desires. Moves in a grid-like fashion, trap-line monitoring

Requirements: Nature, Keys to the gates, Seating 


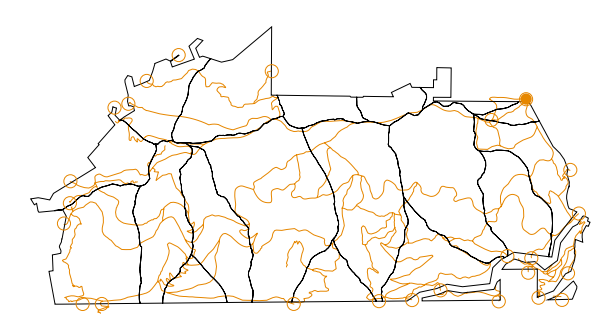

WELD ST
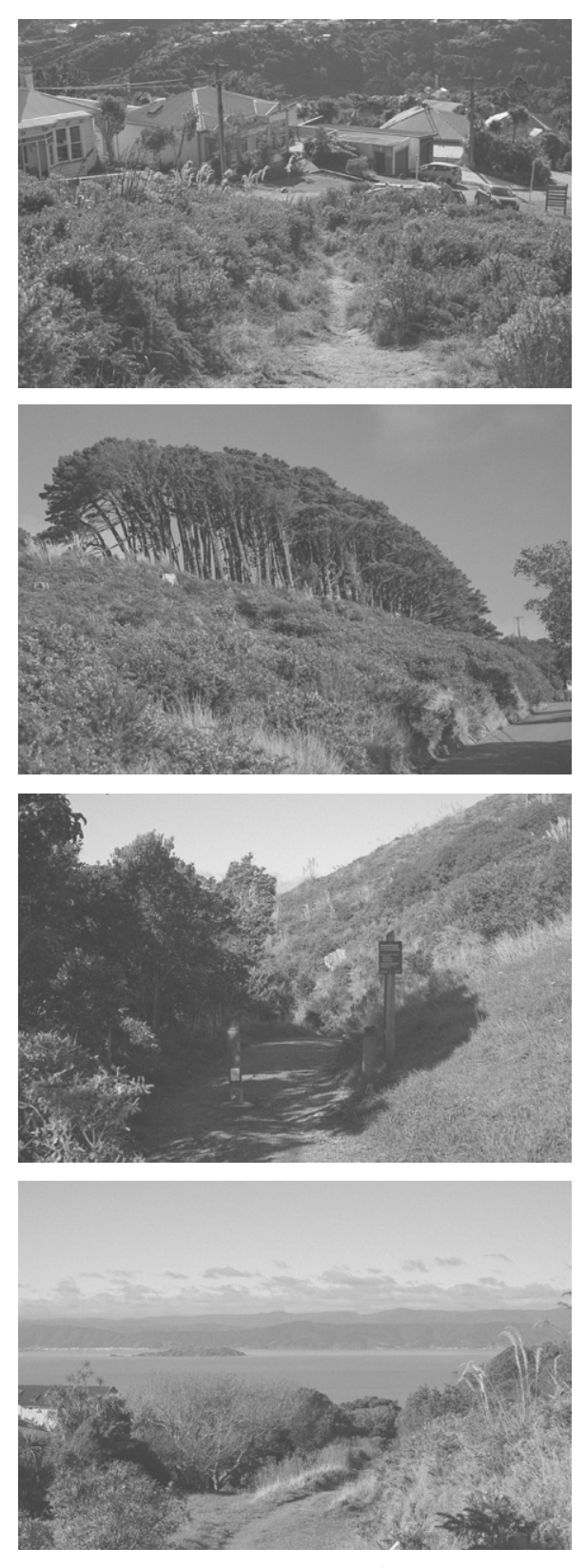

Weld St entrance forms the start of the Northern Walkway track and Te Araroa Trail. Toetoe spring from regenerating hillsides of gorse

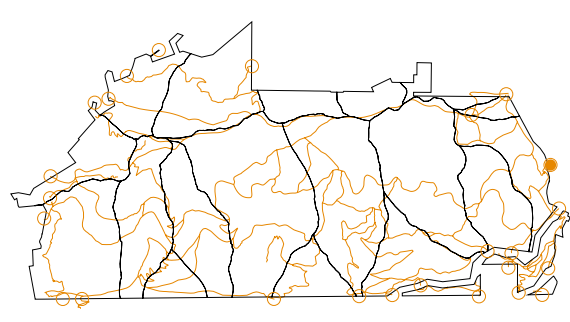

MOORHOUSE ST
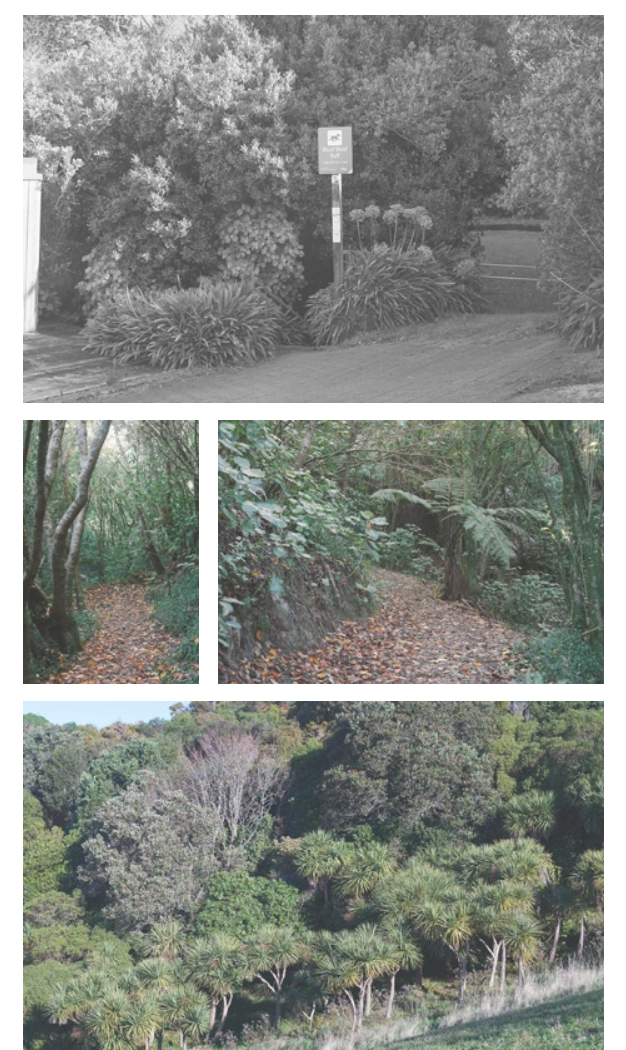

Moorhouse entrance, winds through the upper part of Te Waipaekaka stream. A damp mixed native and exotic forest, drops orange leaves along the track in Autumn. It

emerges on a steep grassy slope with

views out to Wellington Harbour

trees.

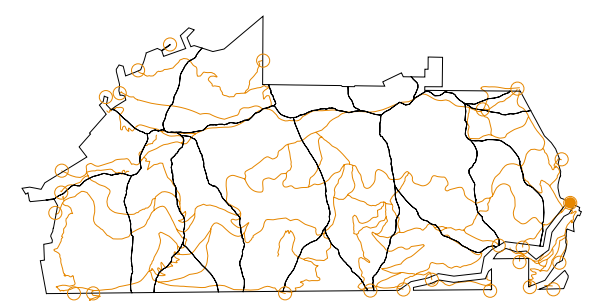

WADESTOWN RD NORTH

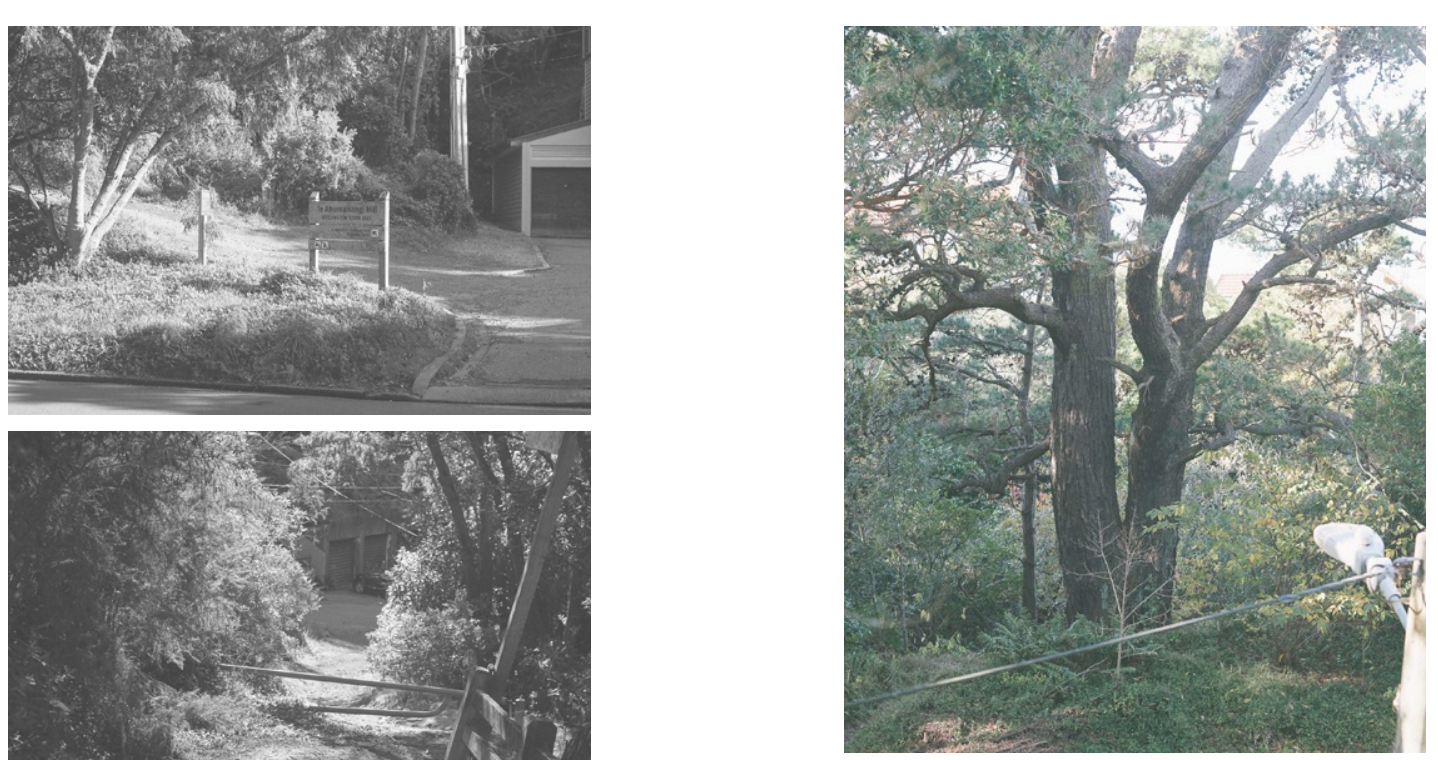

The northern Wadestown Rd

entrance is steep and gouged out

by access vehicles. It is marked by a

kowhai, crossing the road will bring

one to an entrance to Queens Park.

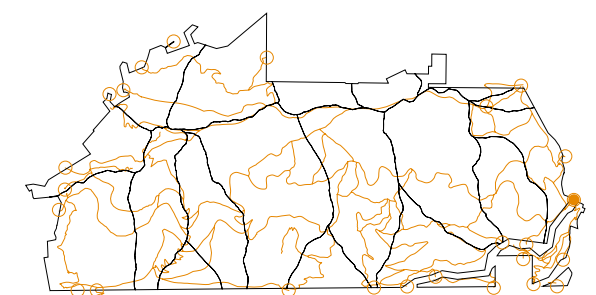

UPPER QUEEN'S PARK
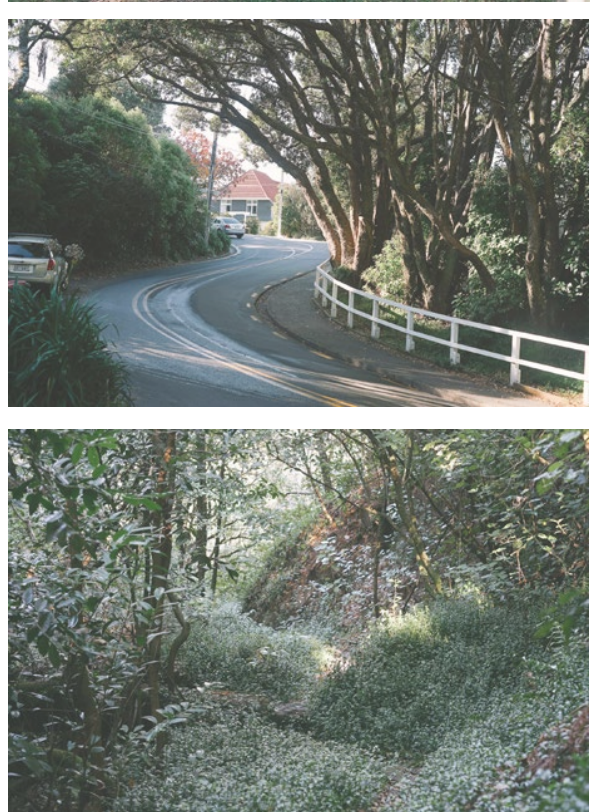

The north-western Queens Park entry is obscured and only revealed on inspection of the giant pine tree marking it. The track is overgrown and snakes past a waterfall and through deciduous oaks.

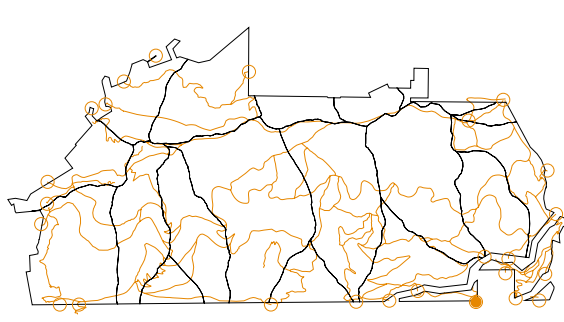

LOWER QUEEN'S PARK
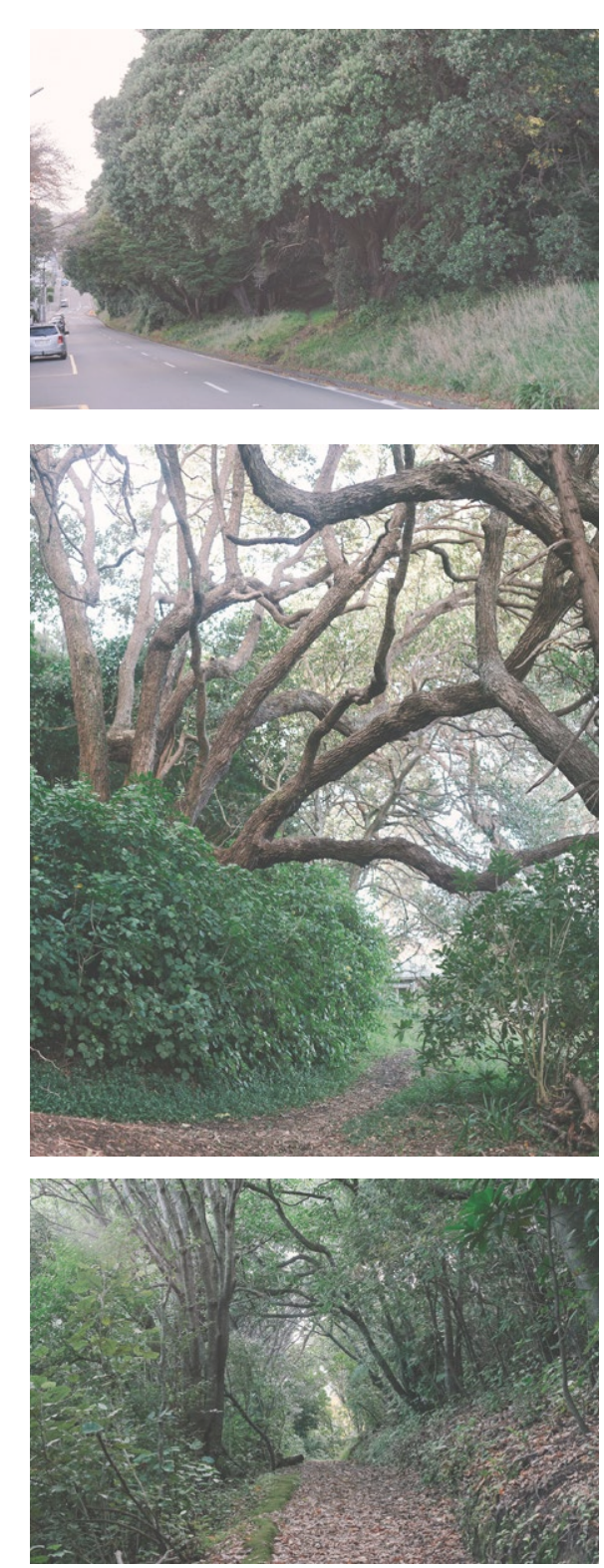

Lower Queens Park is wall of green seen from Grant Road. Underneath the canopy very old pohutukawa wrestle above head.

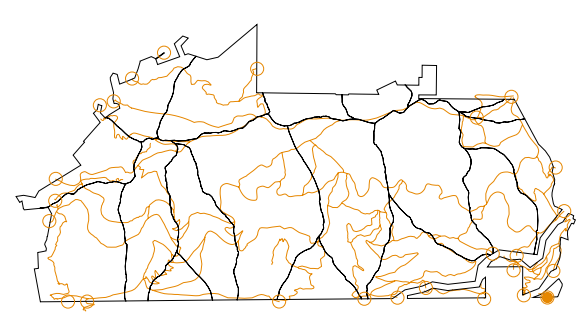

GOLDIE'S BRAE
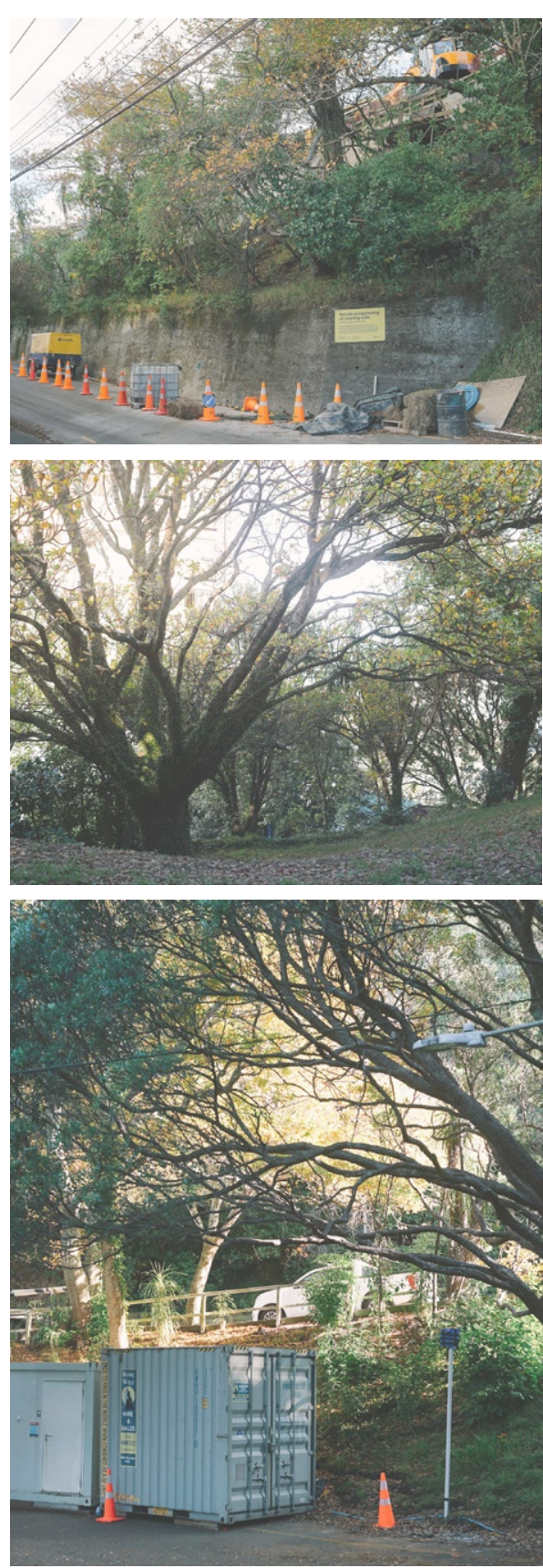

Goldie's Brae was once a Victorian strolling park, today it seems empty. Large oaks and natives punctuate the small lawn. 


\section{Entrance Experiences}

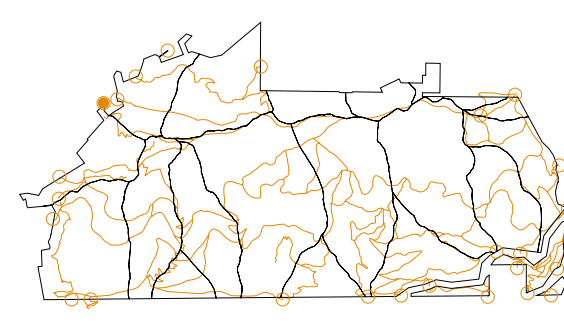

GLAMORGAN ST
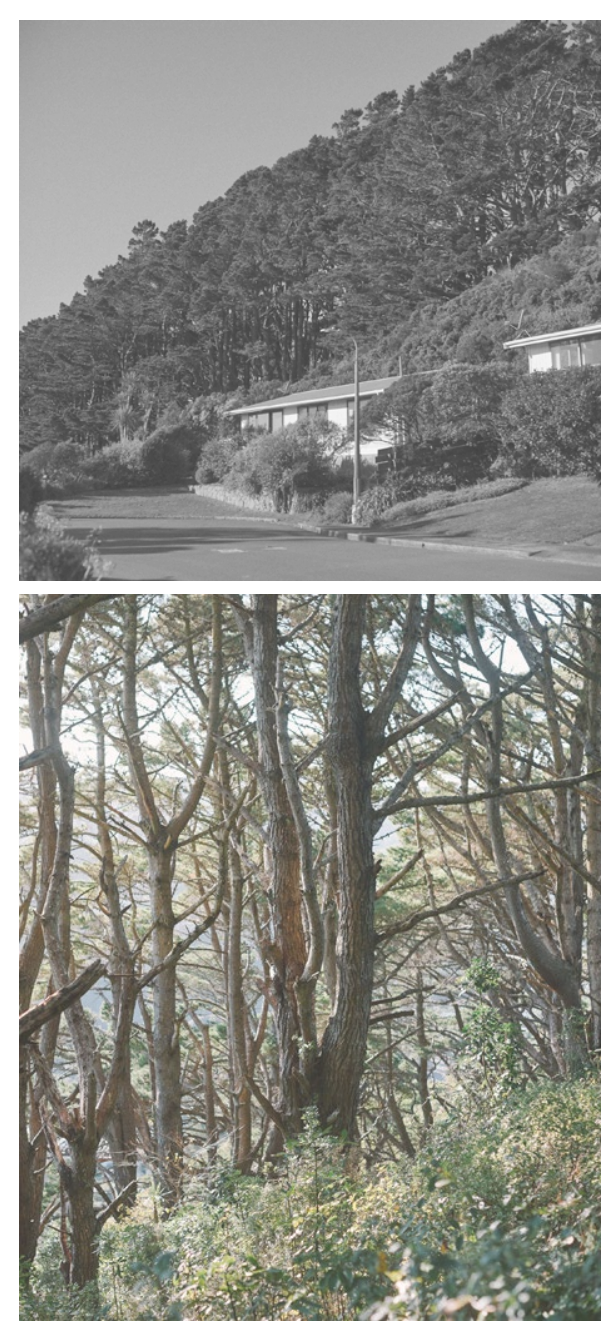

Glamorgan entrance is one of my favourites, carpets of Hound's tong fern and the frequent presence of entry.
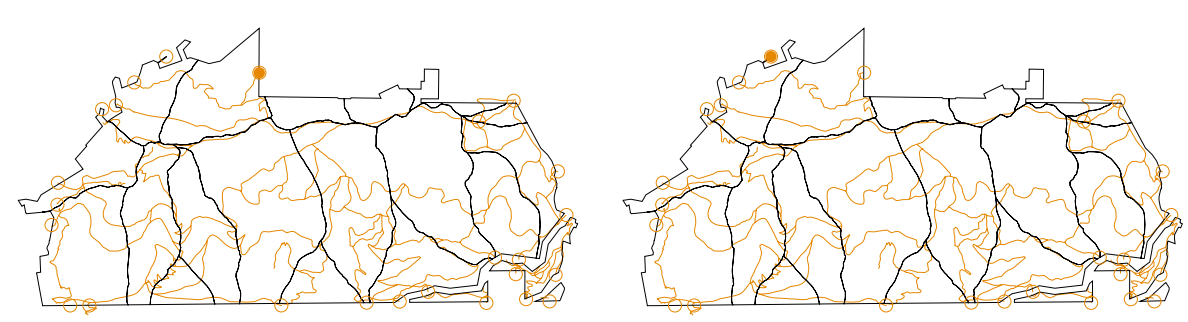

CECIL RD

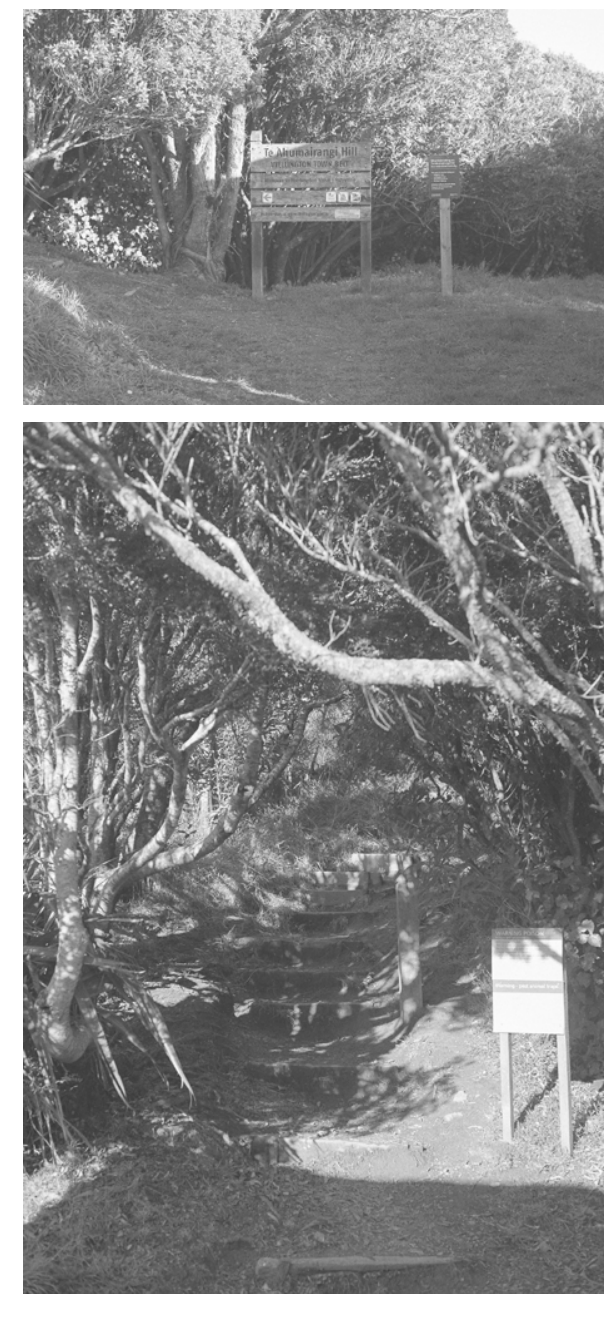

A long flight of wooden steps make their way up the hill. The plantings of native beech are not often seen in Wellington City. of public and private. What is and
MONMOUTH WAY
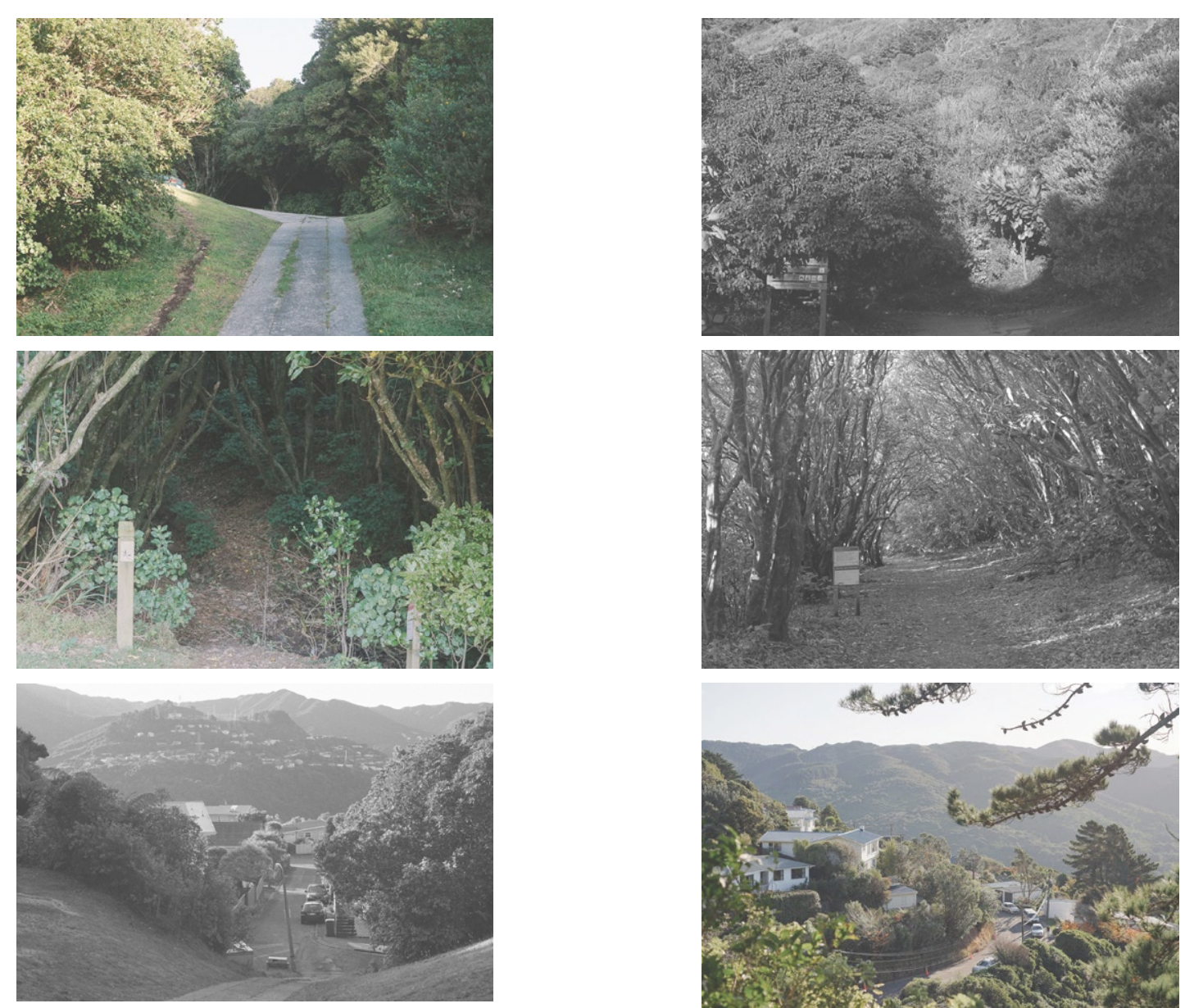

Monmouth entrance is a strange sort of entry, owing to its odd sense appears as private driveway actually has access at the top. This damp valley is full of supplejack and kawakawa.

Huntingdon entrance takes one along the old tramway used to remove stone from the Kohatu Quarry. The width and flatness of this path is uncharacteristic of Te Ahumairang.
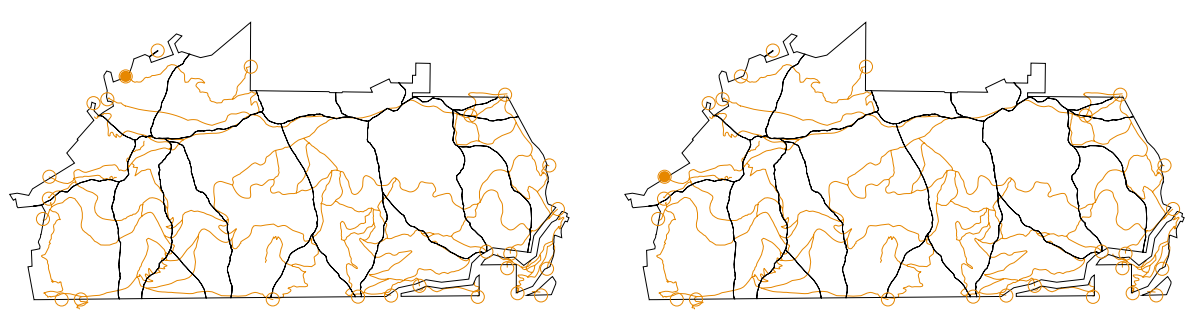

SOUTHERN CAR ACCESS
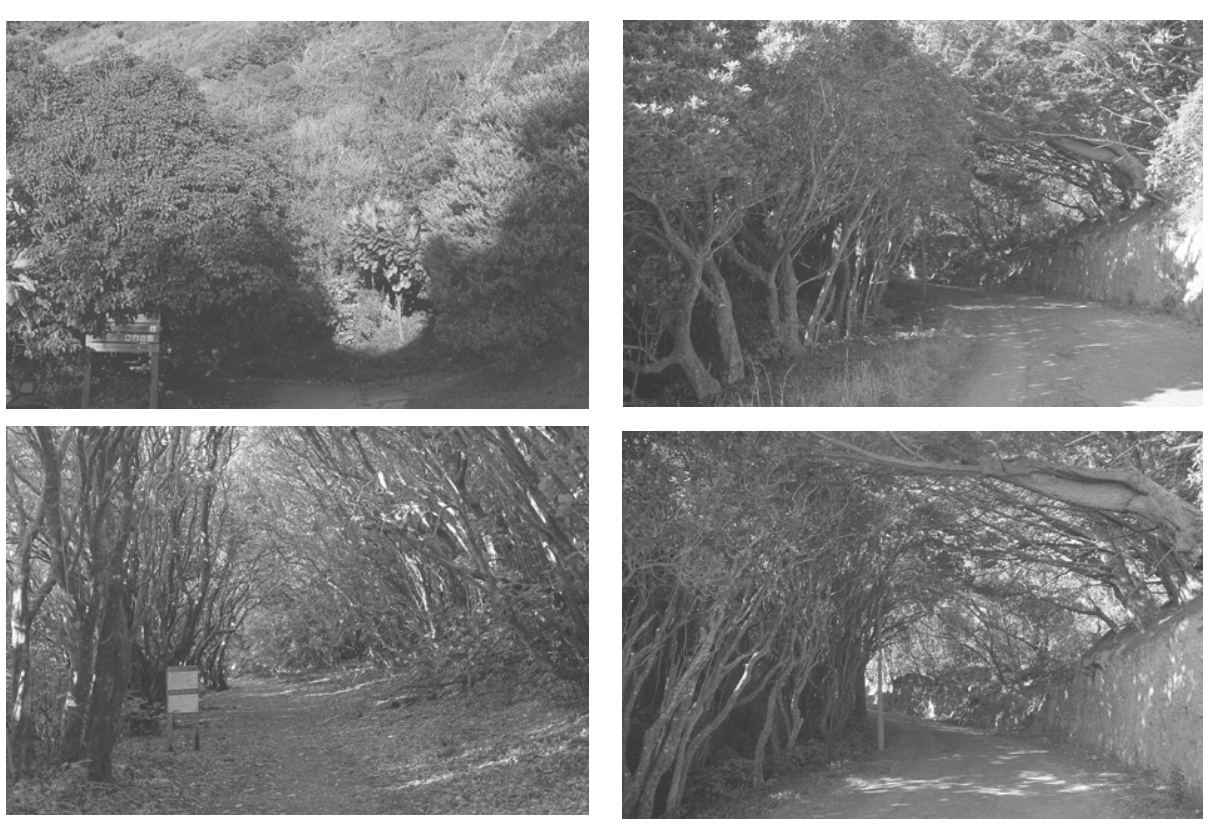

toweses

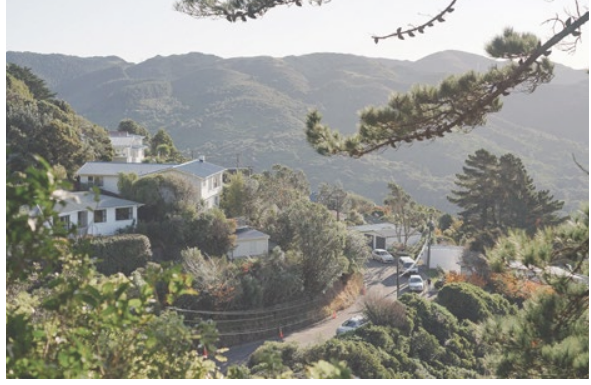

The Northland vehicle entrance to Te rocky cutting and a dark valley. The road is in poor condition and is very steep. Huge macrocarpa from early plantings arch over the road.

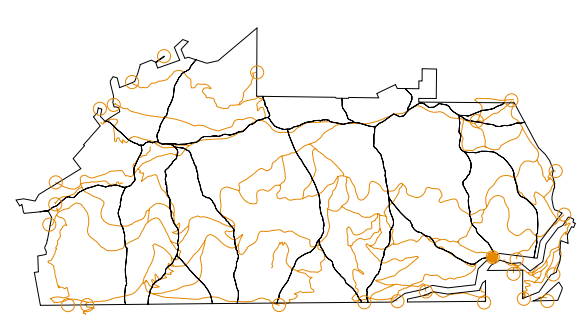

WATERWORKS
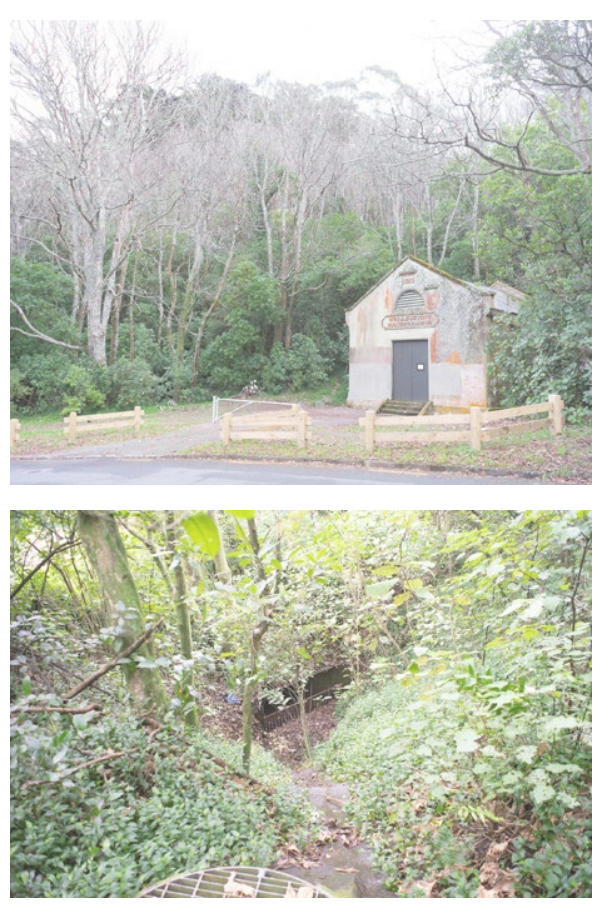

The waterworks are remnants of the days when the water reservoir at the Weld St carpark was used to supply Wellington City with drinking water. 


\section{Landform}




\section{Landform Structure}

Geometries of Te Ahumairangi and

vegetation.

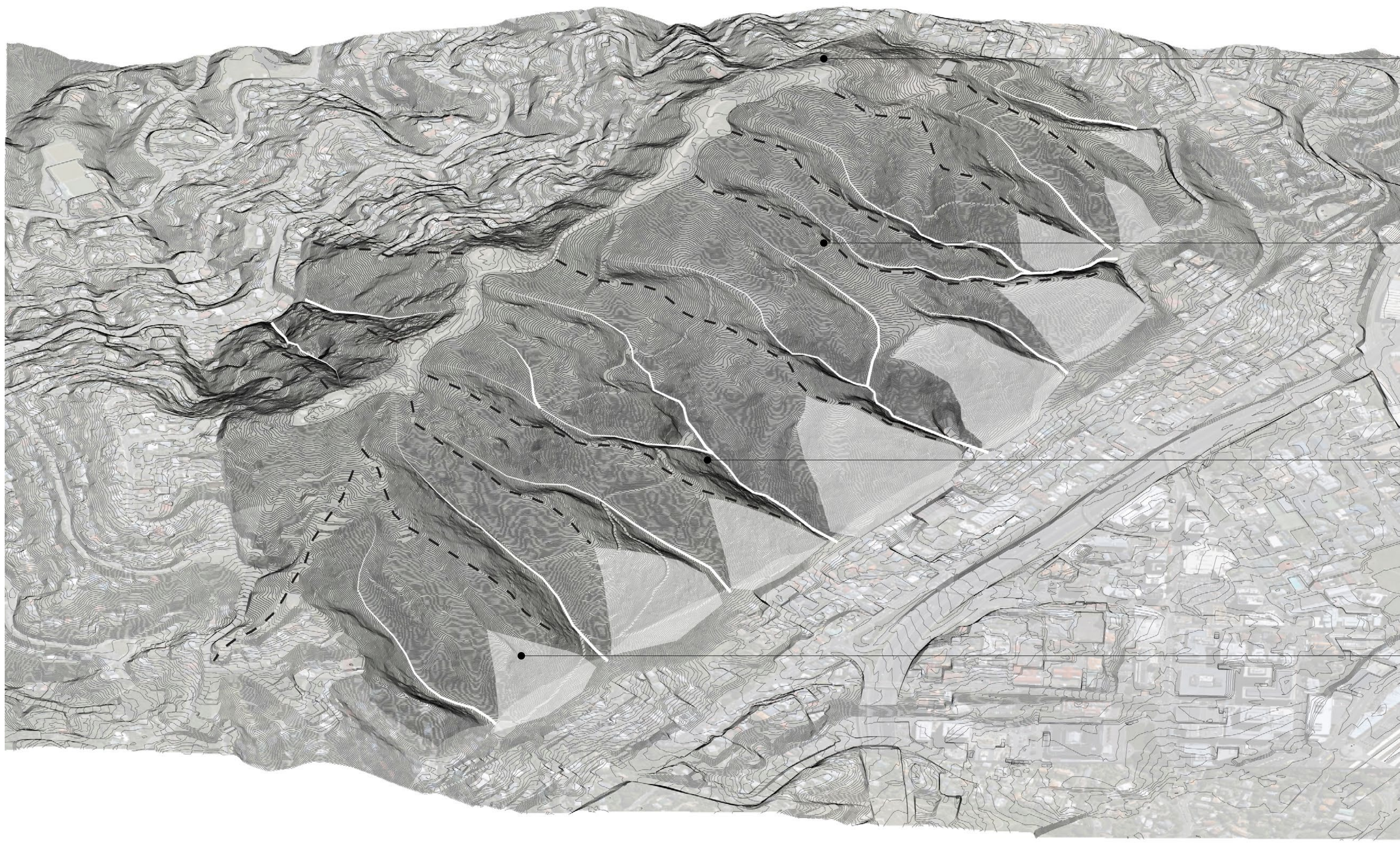

\section{Ridgetop}

The ridgetop is currently utilised for recreation and is popular for its views over the city and western suburbs. It extends for just over $1 \mathrm{~km}$. The ridgetop is maintained as grass, plants are exposed and buffeted by strong wind.

\section{Ridgelines}

There are 12 major ridgelines that structure the experience of $\mathrm{Te}$ Ahumairangi. Pathways utilise the ridges as connectors between the
ridgetop and northern walkway. They provide filtered views through pine forest out to the city. They are drier which is reflected in the vegetation.

\section{Valleys}

There are 10 major valleys that structure the experience of $\mathrm{Te}$ Ahumairangi. They are damper, darker and tend to be rocky. They space. Mahoe, kawakawa and ferns carpet the valleys.

\section{Steep Faces}

There a 9 roughly triangular steep faces. They all face the city and are important in how the wider city

perceives Te Ahumairangi. Their verticality against the city means they are mostly what is seen of the hill. 
Slope Map

Key

$0-10 \%$

$10-20 \%$

20-30\%

$30-40 \%$

$40-50 \%$

$50-60 \%$

$60-70 \%$

$70-80 \%$

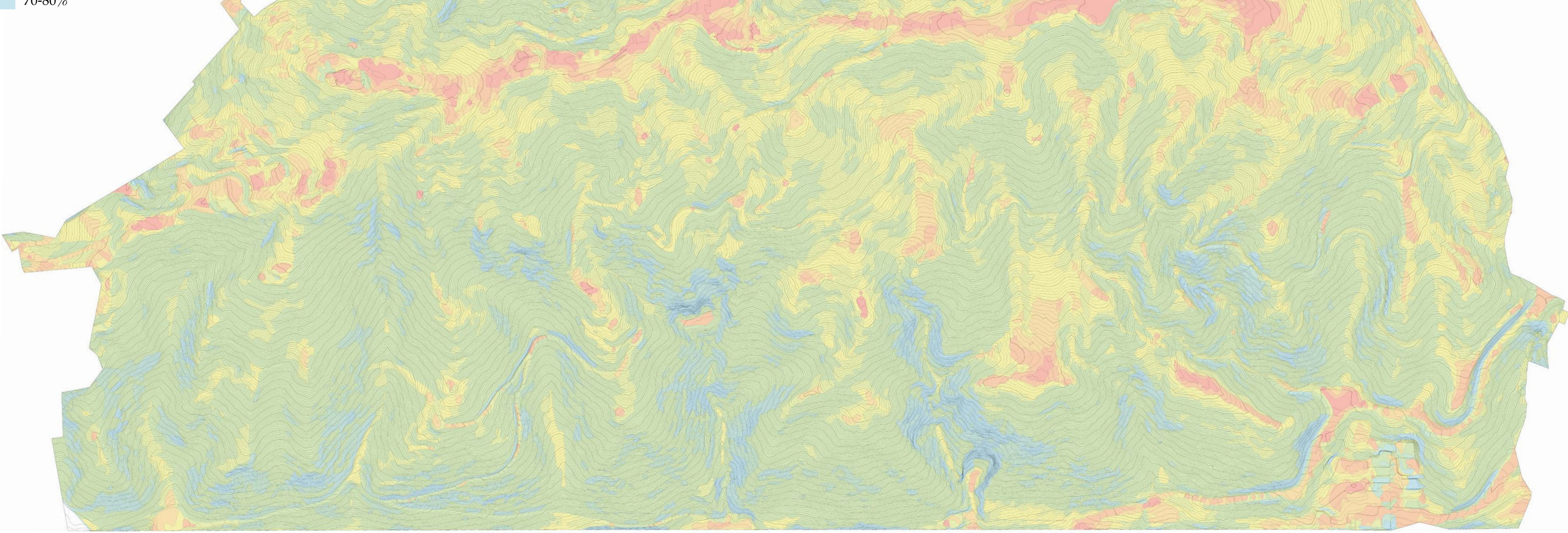

The only particularly flat areas are

those modified by

ridgetop accommodate bodily burial and 40-

$\begin{array}{ll}\text { ridgetop has been graded as a rough } & 60 \% \text { would be able to accomodate } \\ \text { road in the past and in the south } & \text { urn burial, } 60-80 \% \text { slopes amre likely }\end{array}$

the flat ase show in the south

buildings once lay. The miltary

of note is to the east and was a Māori

kainga. 


\section{Geological Map}

Key

Greywacke Mudstone
Greywacke Mudstone-loam
Go: Greywacke Scree

Greywacke Boulders

Exposed Rock

Greywacke Cliffs

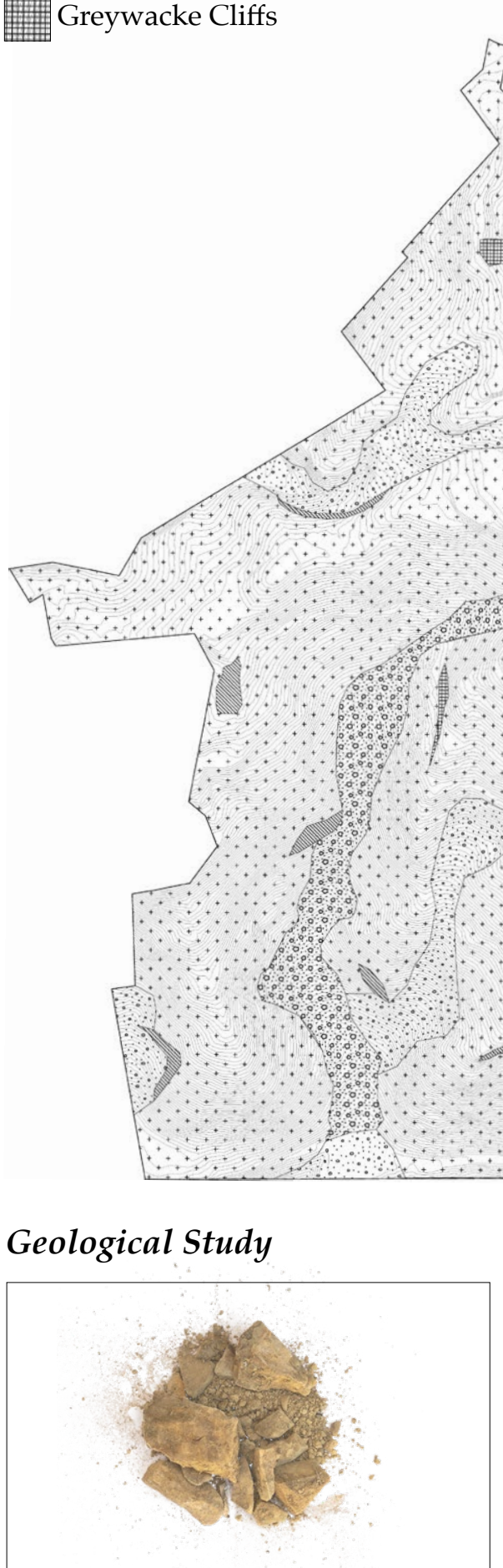

\section{Geological Study}

Geological studies of Te Ahumairangi do not exist. A series of geological samples were collected through

fieldwork to help understand the

distributions of geology across the

site.

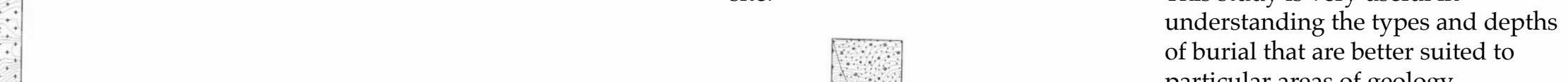

particular areas of geology.

As a generalisation, greywacke tends to fall into the valleys whereas mudstone comprises many of the drier ridgelines.

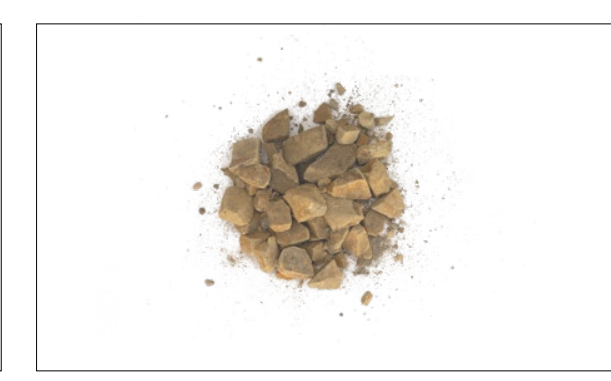

Soft Mudstone Scree

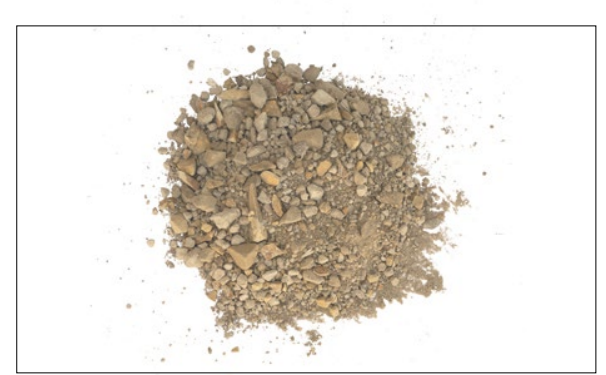

Mudstone Soil

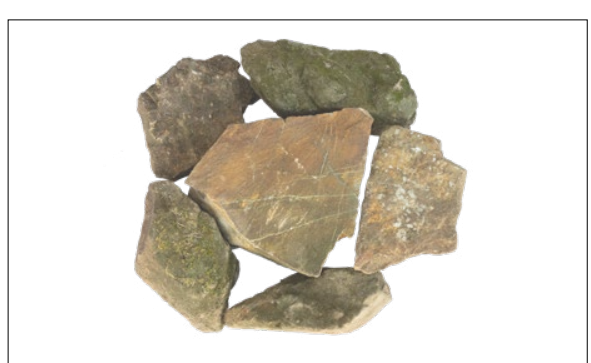

Hard Greywacke

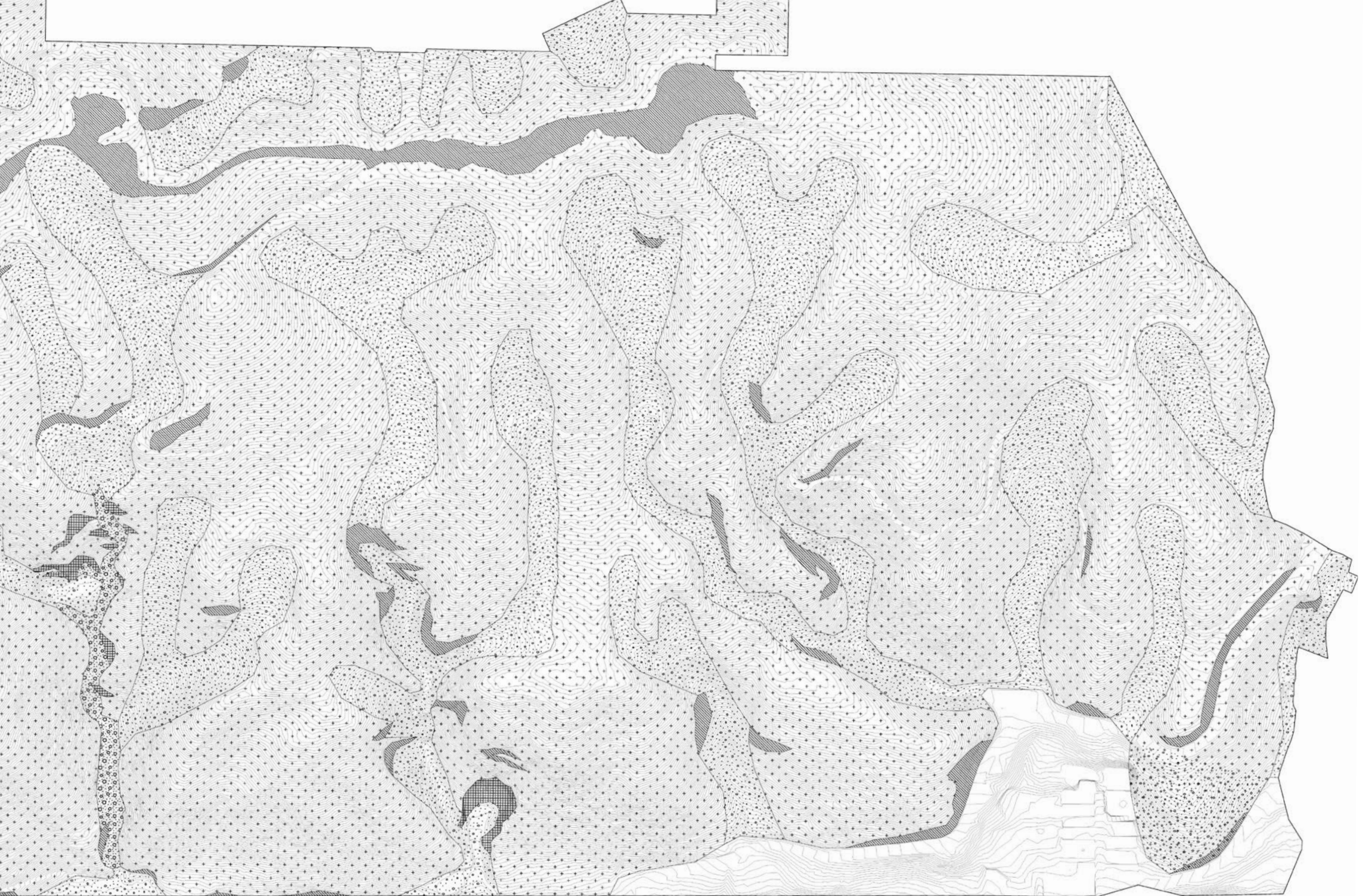




\section{Hydrology}




\section{Historic Streams and Kāinga}

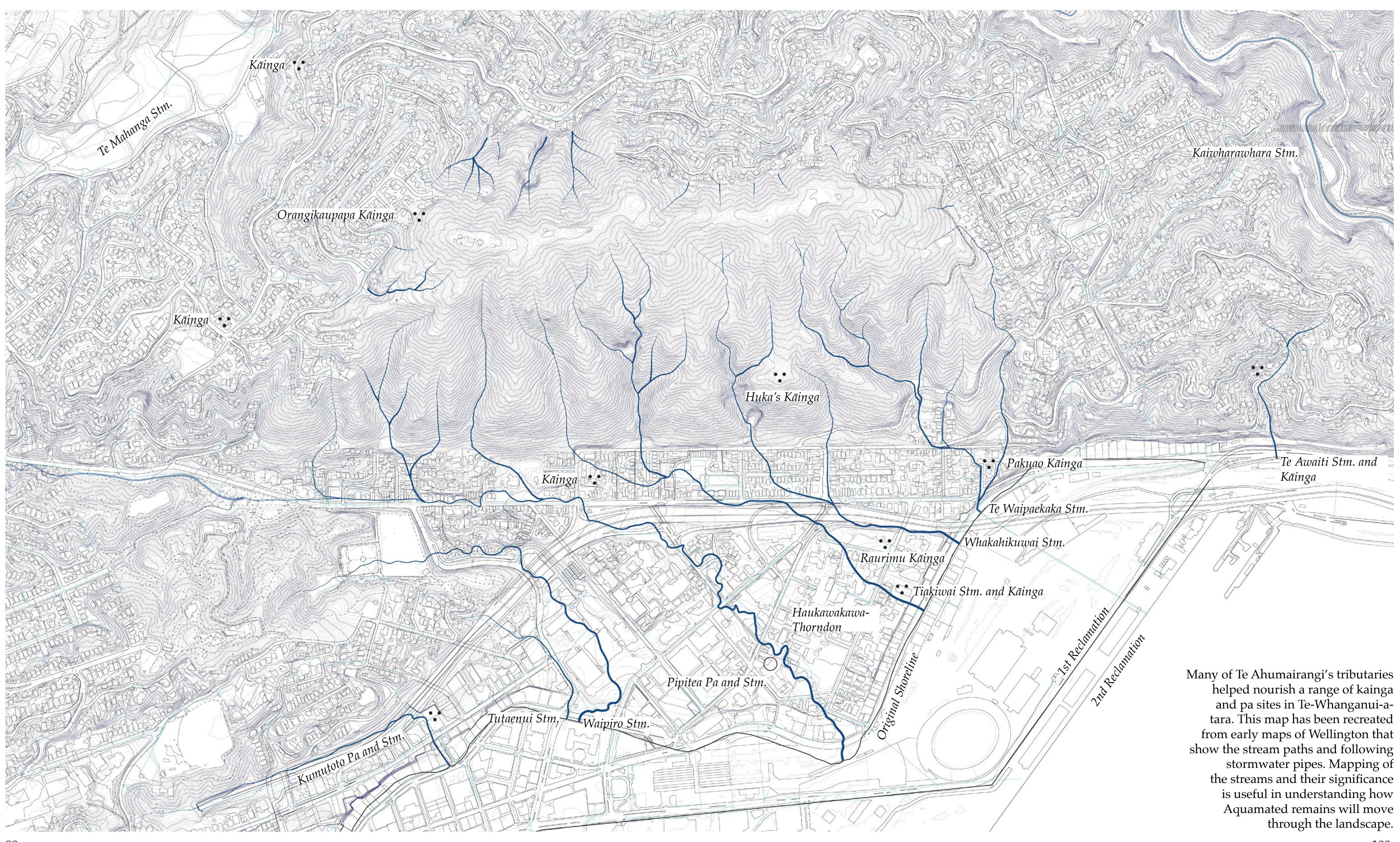




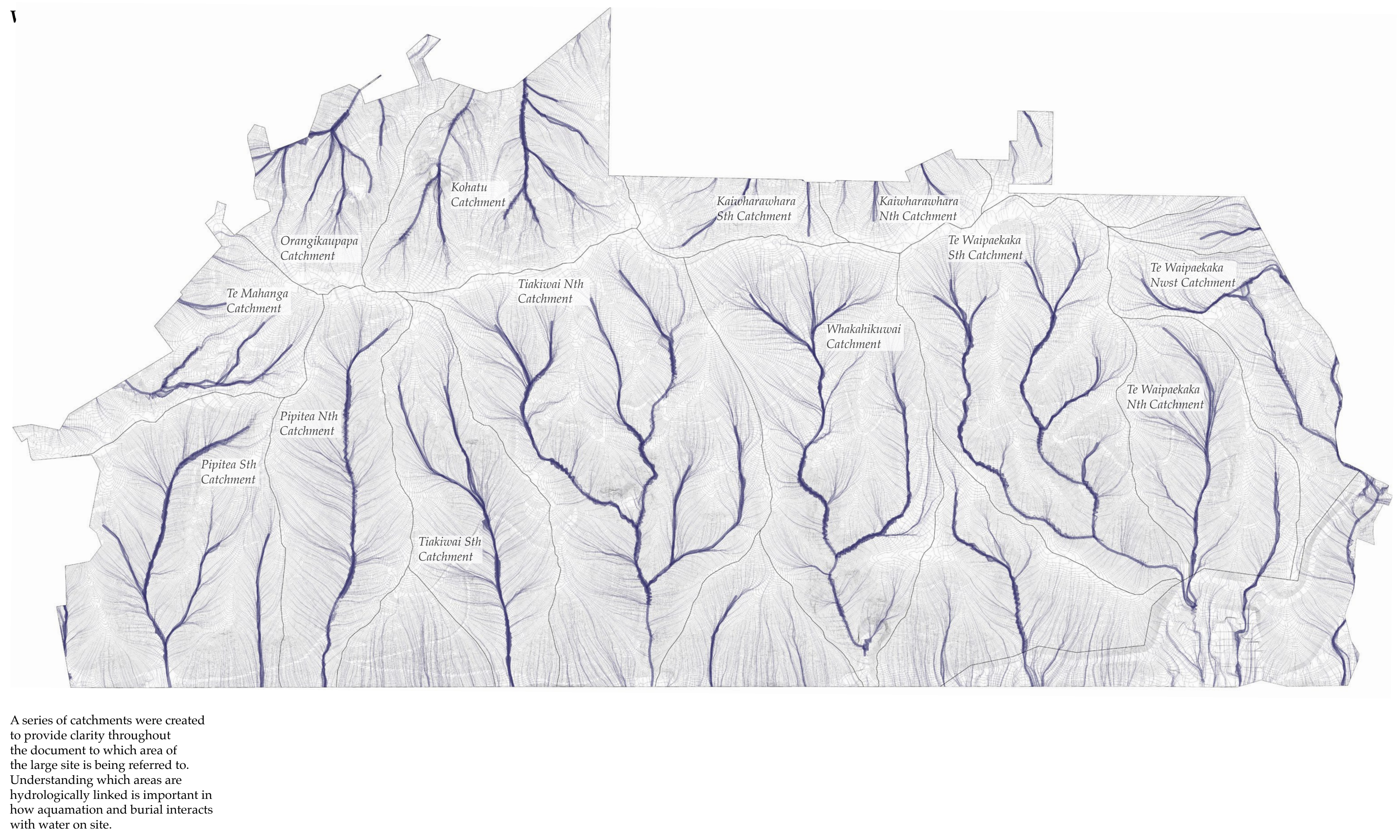




\section{Saturation Gradient}

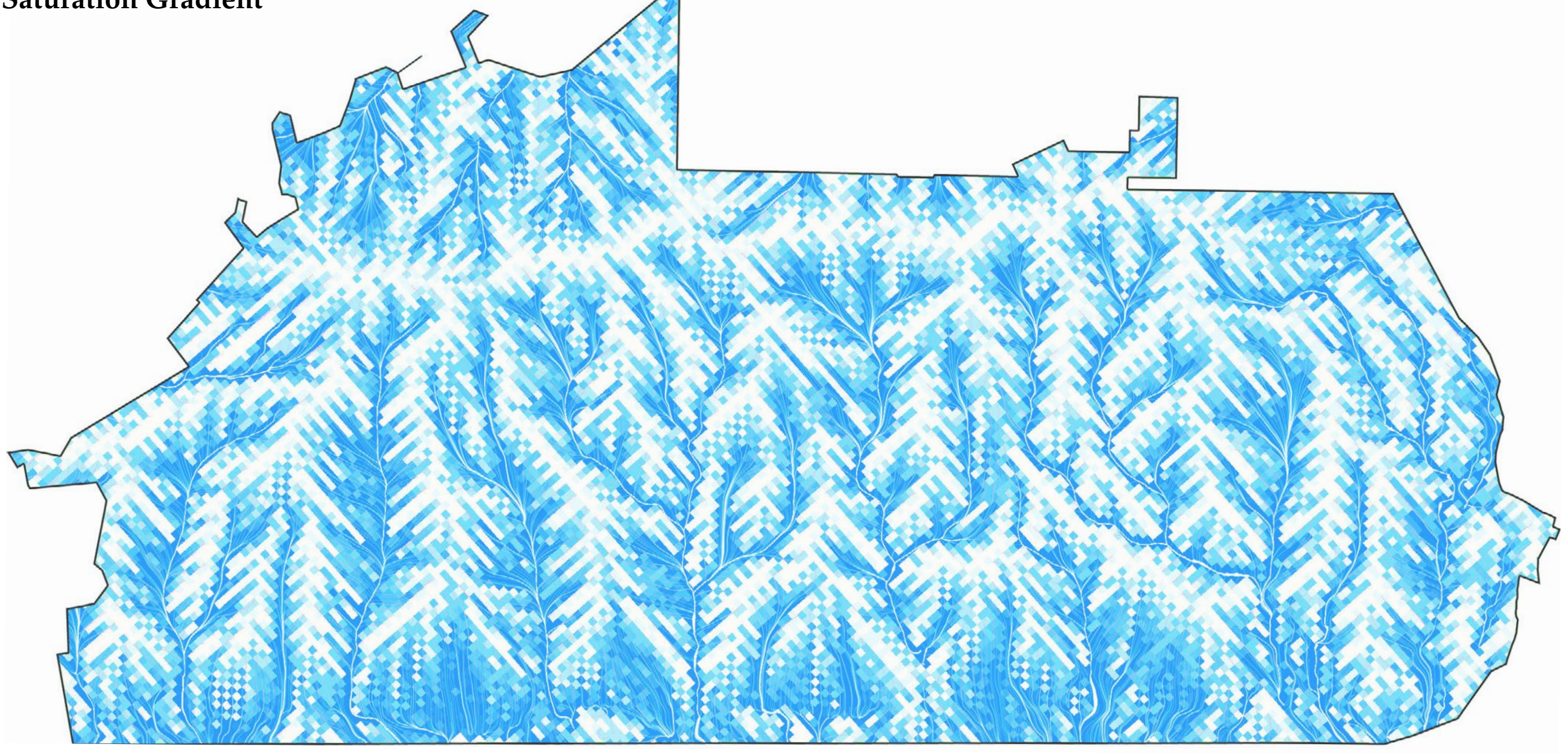

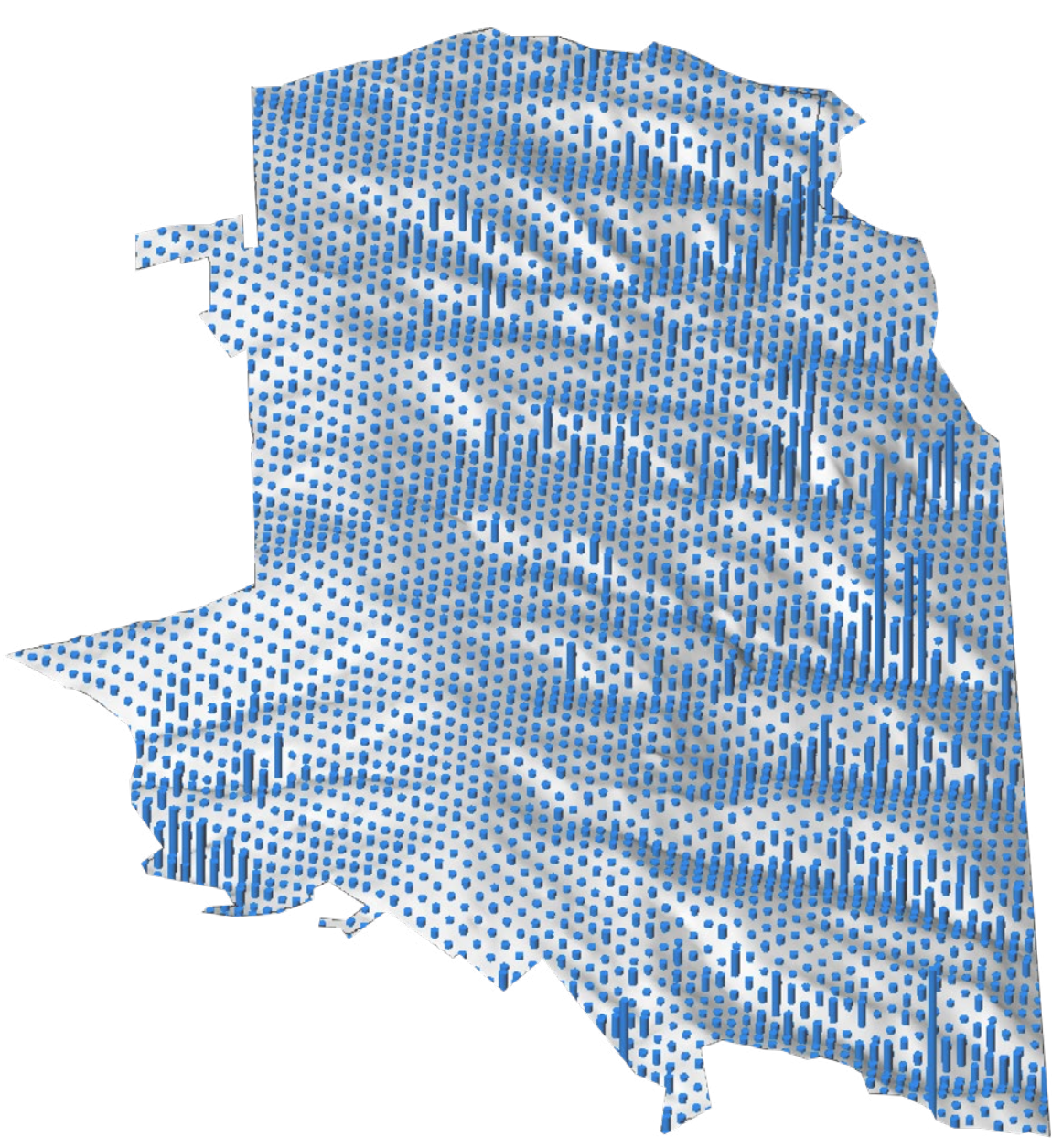

The software allows for other visualisation methods such as representative bars of varying loss based on porosity of soil type offered also. For Te Ahumairangi's greywacke soils this is roughly $12 \%$ and so this was set as the parameter. There is a general trend toward the wettest areas being those about three quarters along valleys on the downhill. 


\section{Flora}




\section{Historic Flora}

This content is unavailable. Please consult figure list for further details.

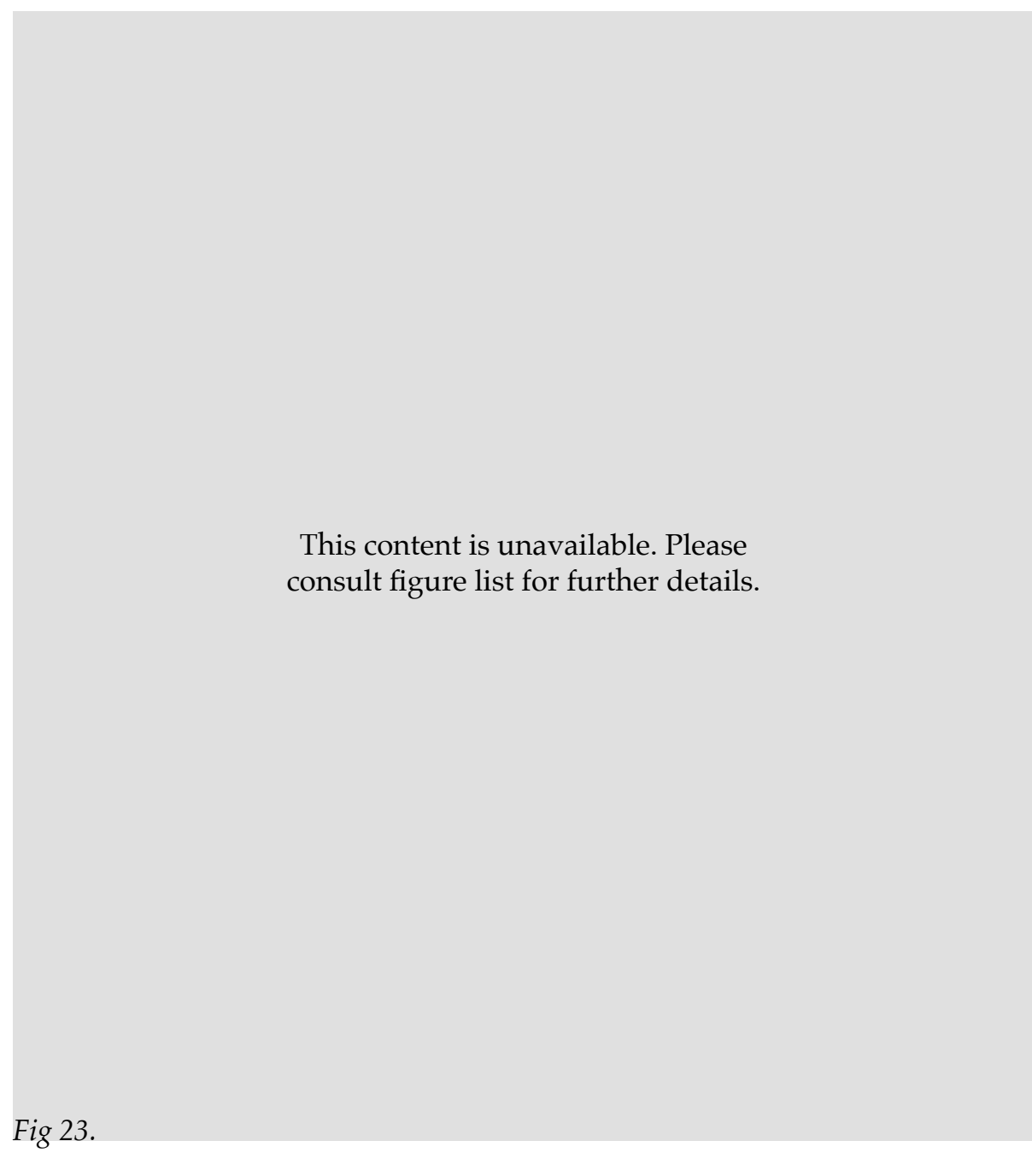

\section{Historic Vegetation}

Wellington's western peninsula was once a tall podocarp/broadleaf forest. Rimu and rata were the dominant emergents, soaring above a dense canopy of tawa, titoki and hinau. Northern rata start their life high up in rimu branches as a seed, and climb down to the forest floor before swallowing its host in a tangle of roots. Wellington's forests was once draped with perching astelia lilies, scented orchids and epiphytic ferns.

The understorey was comprised of treeferns and vines weaving their way up to the light in the canopy.

The forest floor was a carpet of

moss, ferns, sedges and grasses atop decaying plant matter.

These emergent and canopy species are notably absent or rare in the Tow Belt after a many human induced

changes. Most of what occurs on

Te Ahumairangi is still in early

ecological succession and is mainly

species from (fig. 23) understorey and

\section{Current Vegetation}

Te Ahumairangi has had a century of floristic changes, like much of the town belt, exotic conifers, pines and deciduous trees were planted. Today, conifers still dominate on Tinakori Hill and range in age from 60 to 120 years old. The tallest stands reach $25 \mathrm{~m}$ in height The damp gullies and lower slopes of Te Ahumairang under dense conifer canopy host shade-tolerant native species like mahoe, rangiora, karamu, fivefinge hining spleenwort and hound's tongue fern .

Two large storms in 2004 saw mature pine plantations fall in the Town belt especially on Te Ahumairangi. Some of the remaining isolated trees were cleared and for the first time in the memory of most people, part of the Town Belt was bare.

In 2005, thousands of northern rata seedlings were planted on Tinakori Hill, as an attempt to re-establish rata which were noted by early settlers. If the native forest is to be self-

sustaining, then large plantings of rimu, hinau, tawa, titoki, miro, matai, totara, kahikatea, pukatea, fuchsia, kohekohe and nikau is needed. 


\section{Vegetation Composition}

Habitat Key

Pinus radiata forest

Coniferous forest

Exotic and native forest

Native forest

Regenerating native forest

Exotic scrub

Maintained grassland

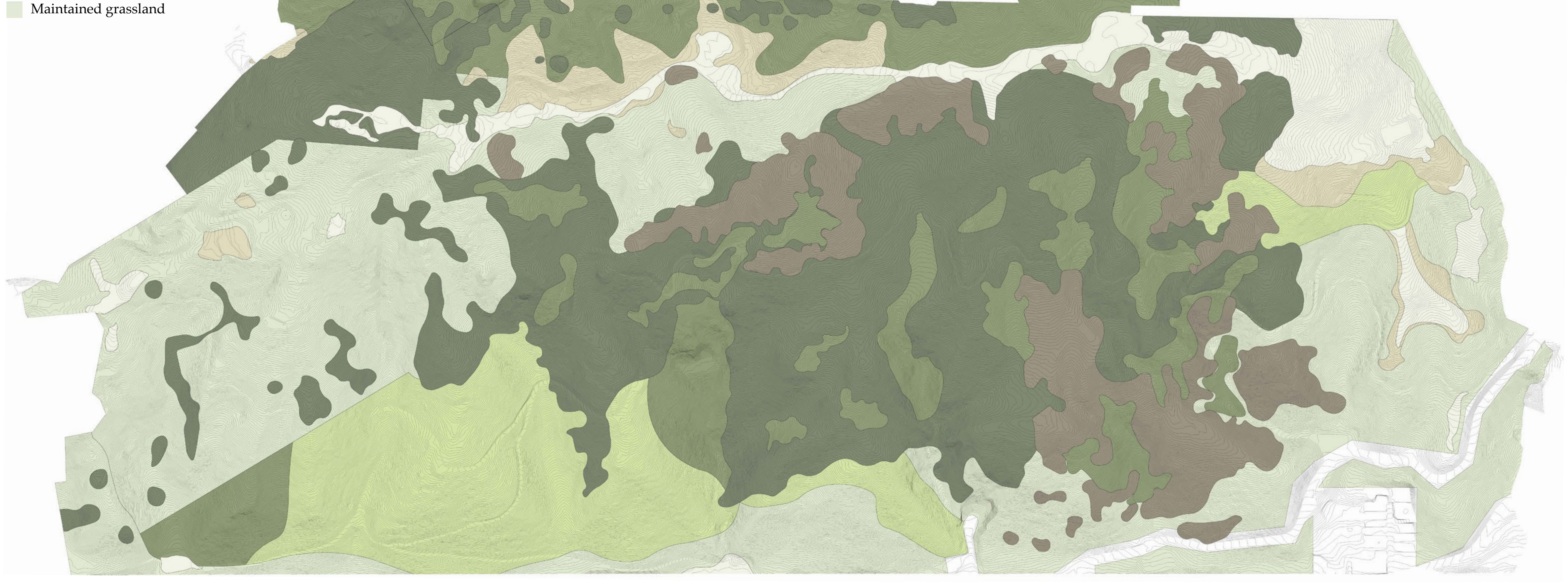

This vegetation study based on a personal and more recent observation than other mappings. Native forest

is primarily comprised of Mahoe and broadleaf vegetation. Regenerating natives are a diverse mix of mahoe,

wineberry, rangiora and other. Coniferous forest are remnants of Cryptomeria and Macrocarpa plantings. Exotic

scrub is primarily gorse and broom. Sections of grassland are maintained for recreation along the ridgeline. There

is a tendency for pine forest to be absent in the valleys, the combination of geology and water seems to have led to

the earlier death of pine. A noticeable diagonal line in the distribution of vegetation owes to a historic boundary line

that was planted with macrocarpa as a windbreak. This study is useful for understanding, the existing vegetation of

the site and how this might change through burial and management over time. Although pine forest is marked as a

singular, there is an incredible diversity of flora below. The following photographic study shows the variation under

pine and macrocarpa. 

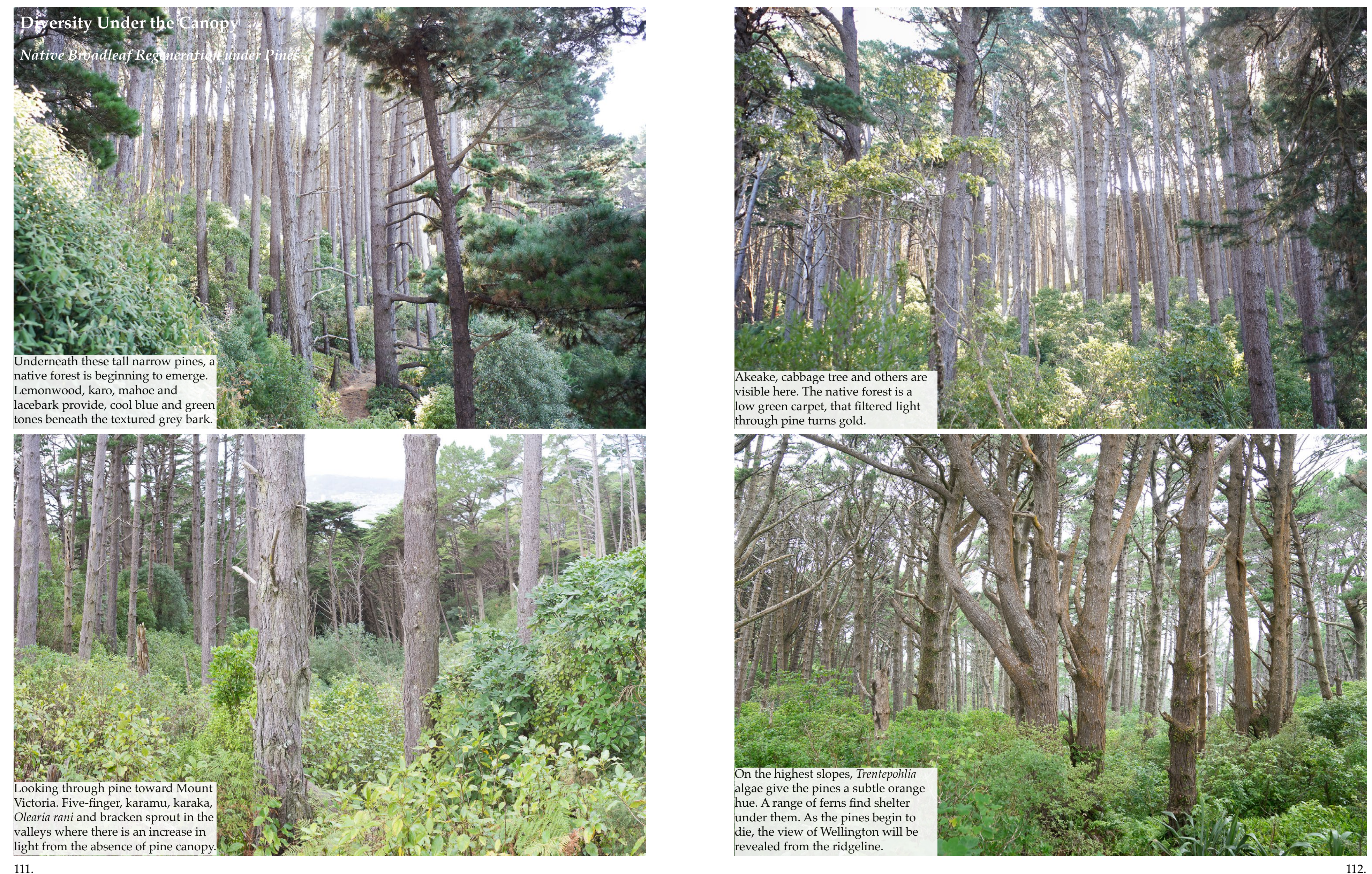

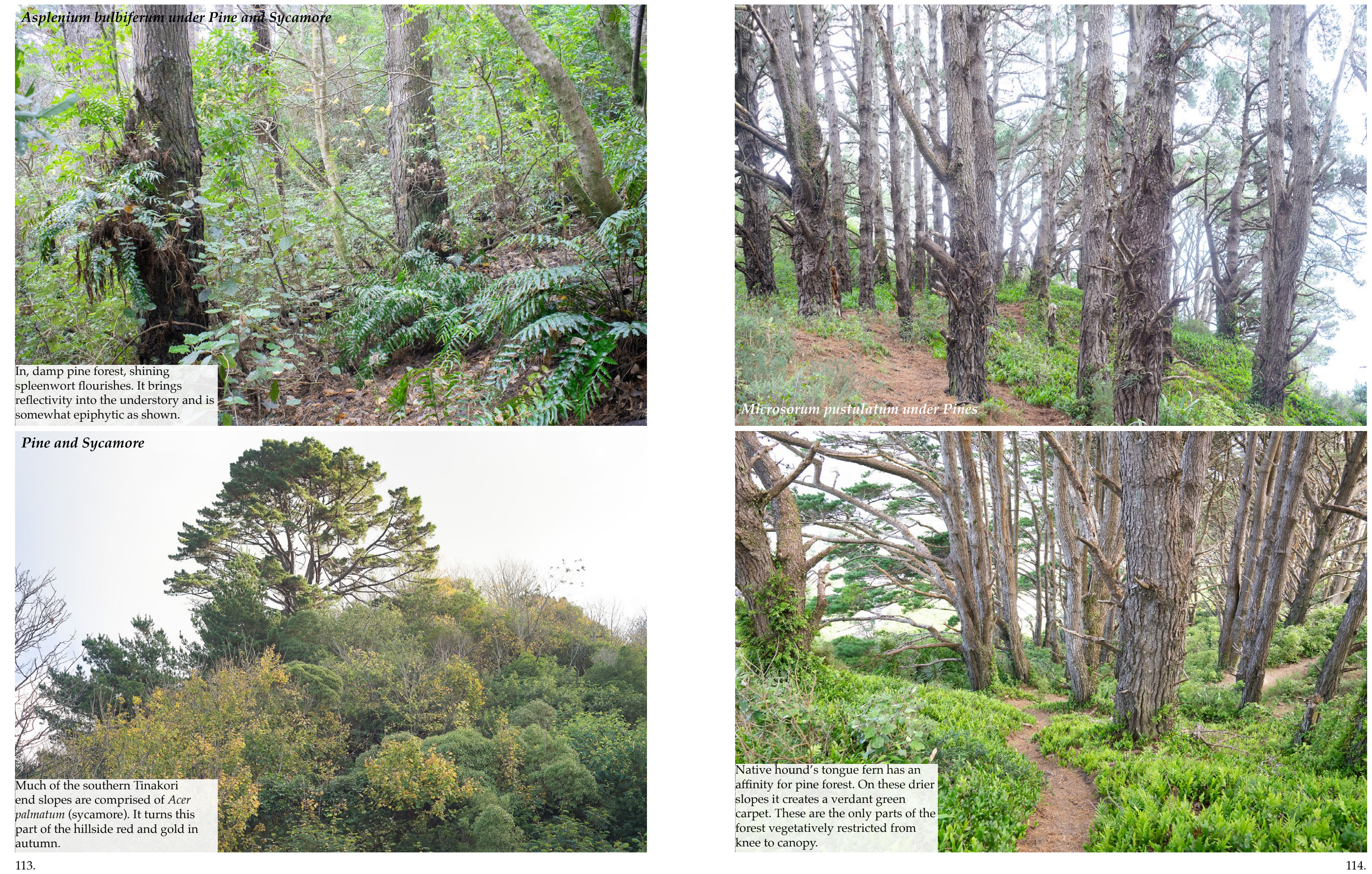

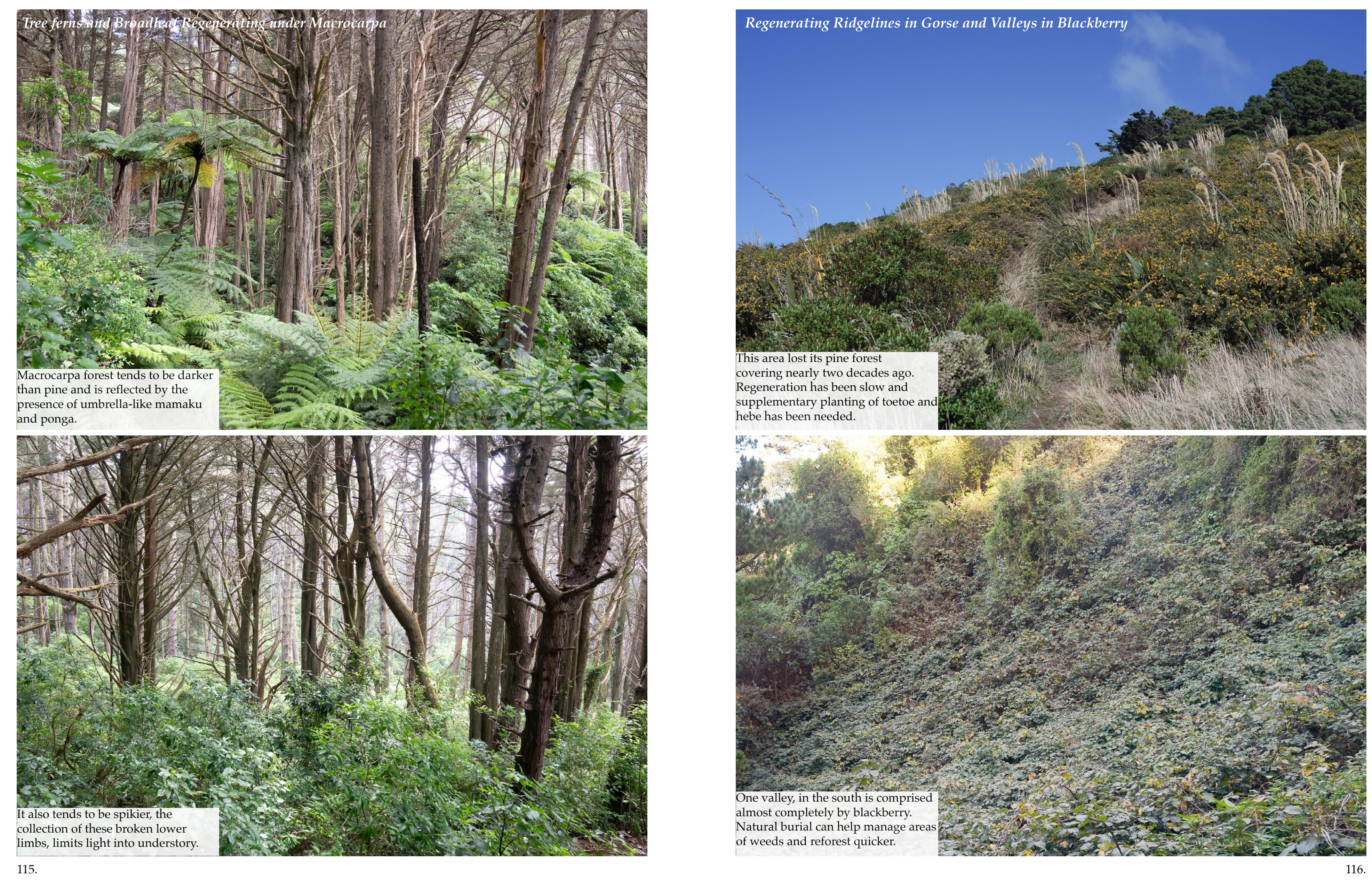

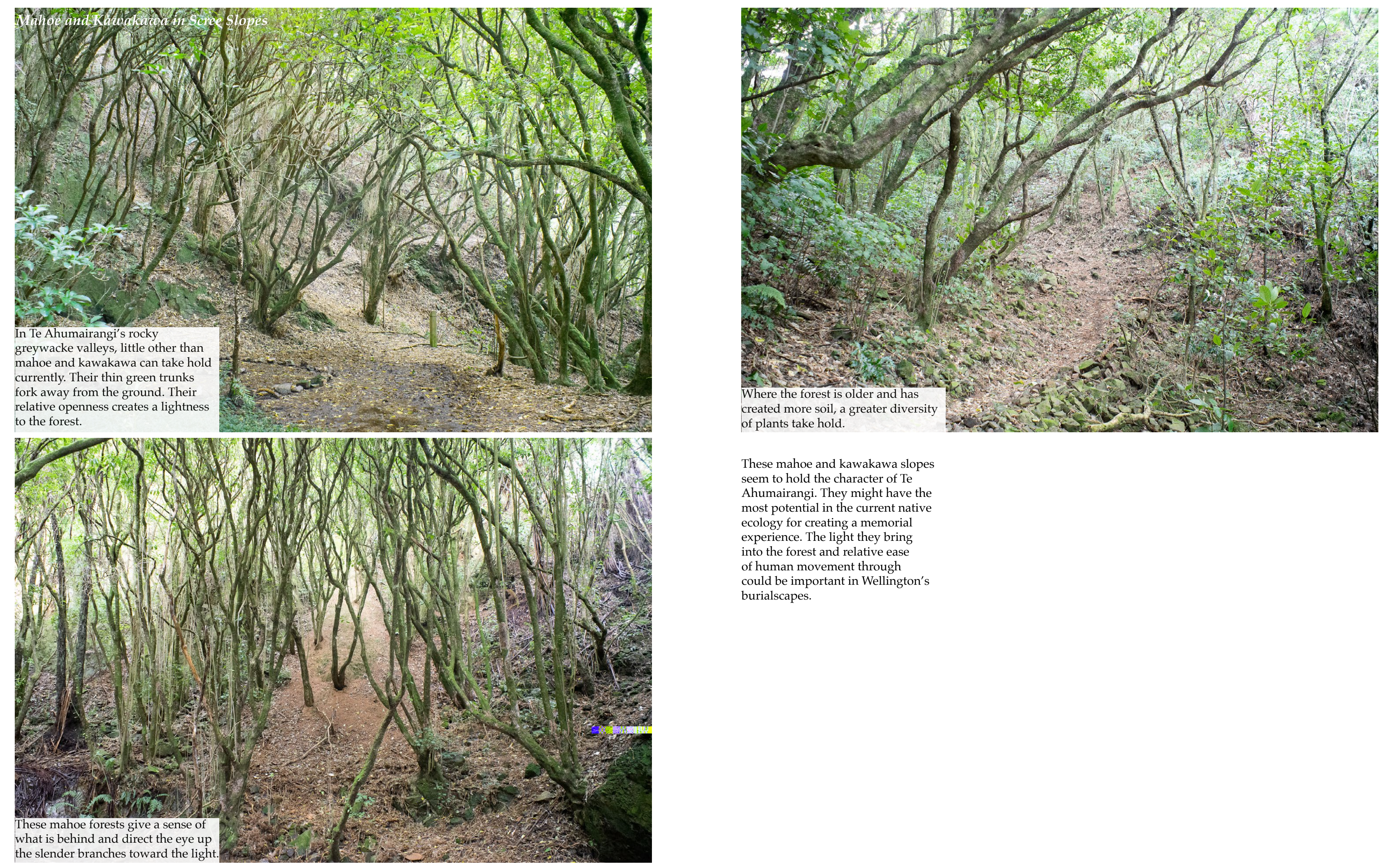

These mahoe and kawakawa slopes

seem to hold the character of $\mathrm{Te}$

Ahumairangi. They might have the

most potential in the current native

ecology for creating a memorial
experience. The light they bring

experience. The light they bring
into the forest and relative ease

into the forest and relative ease

could be important in Wellington's

could be imporialscapes.
buris 


\section{Fauna}




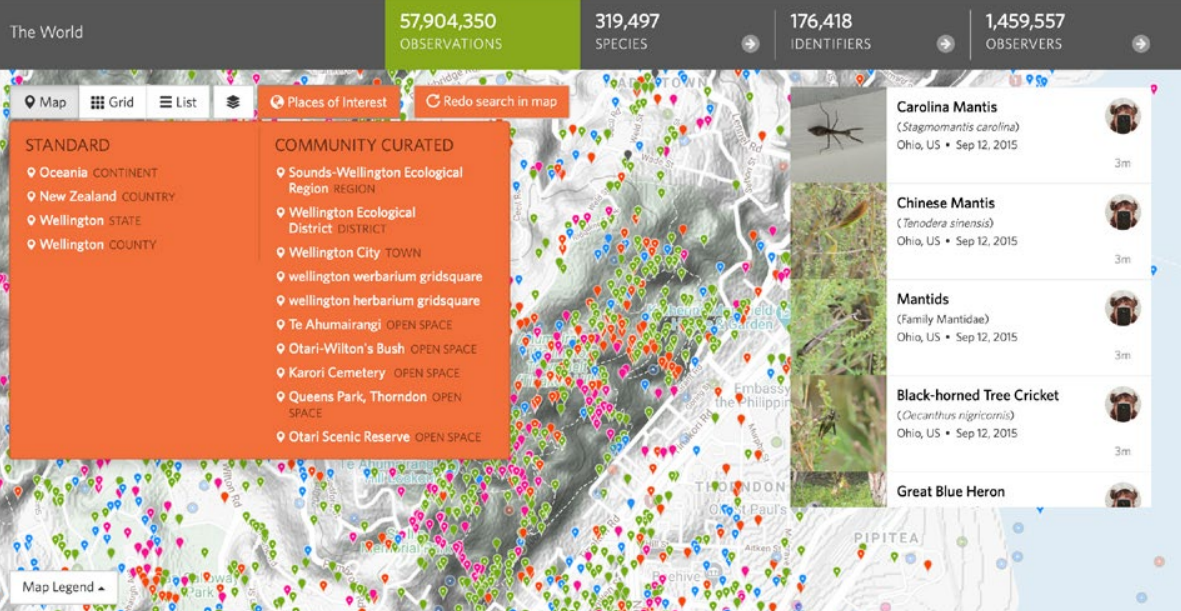

1)

The explore section of Inaturalist, gives places of interest or a bounding box can be created.

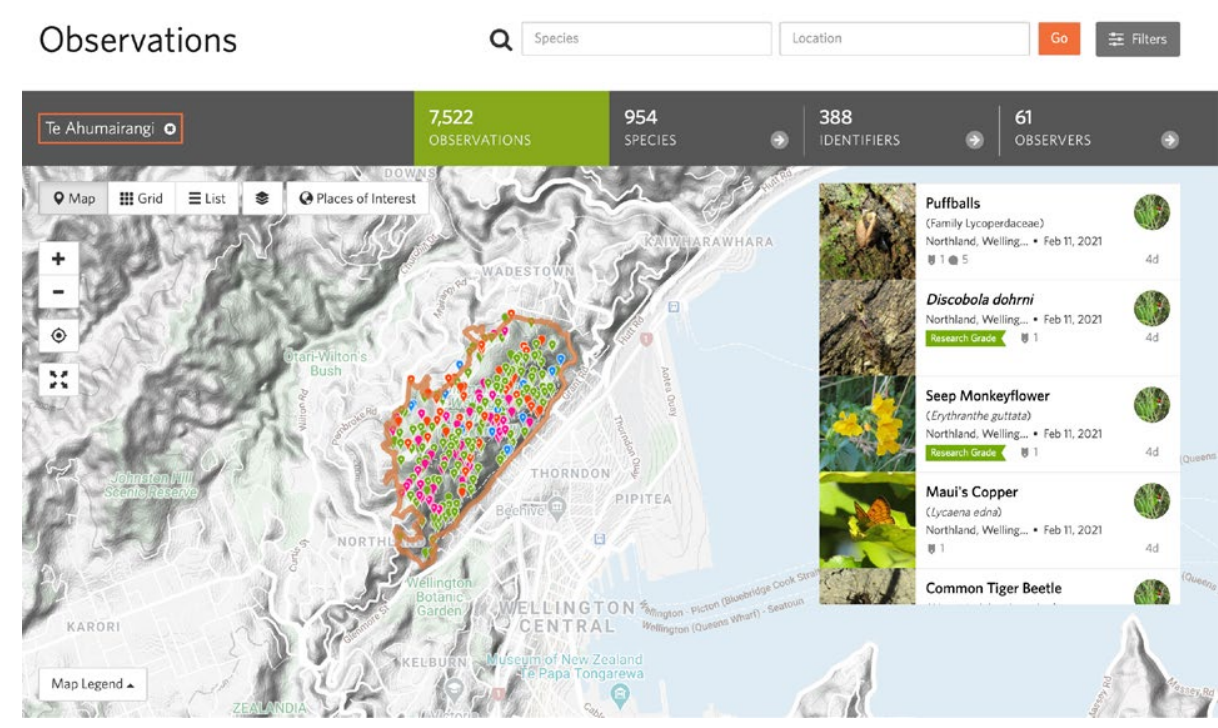

With 7500 observations at Te Ahumairangi there is a lot of data.

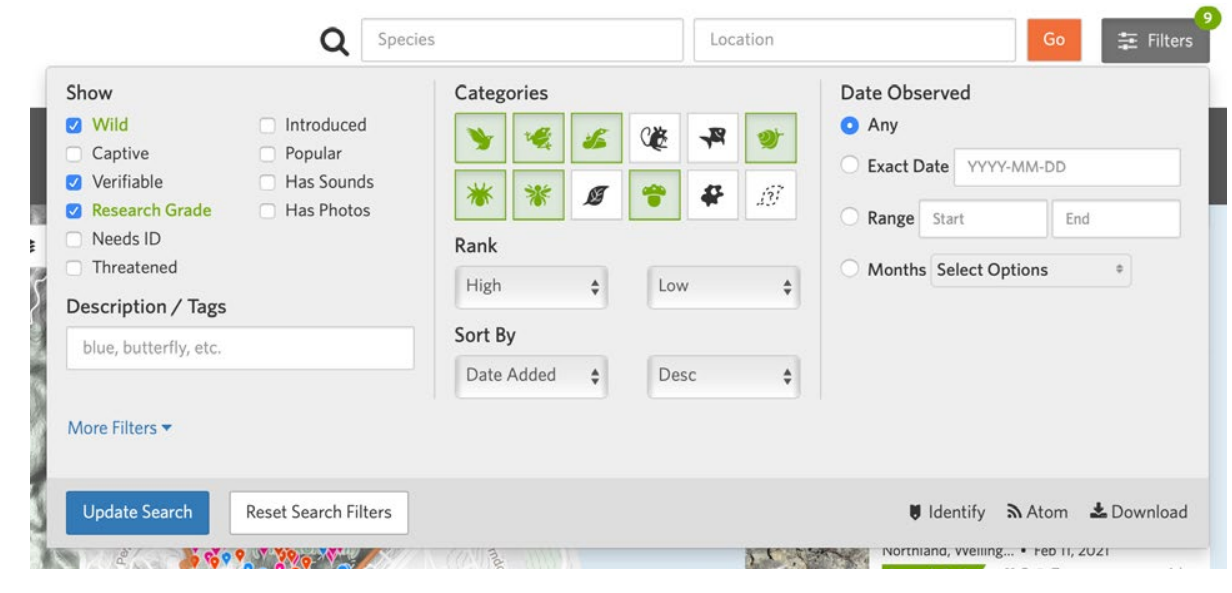

Filters set to include 'wild', 'research grade' and organisms of interest.
INATURALIST TO

MAPPING WORKFLOW

Where no comprehensive animal-life

reports are available, citizen science

allows for fast understanding of

distributions and species of fauna. At

Te Ahumairangi it would otherwise

take month

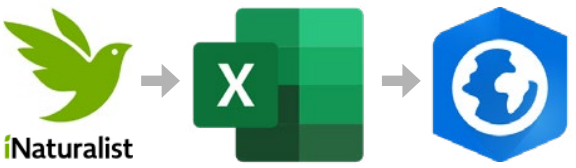

Export Observations

1 create a Query
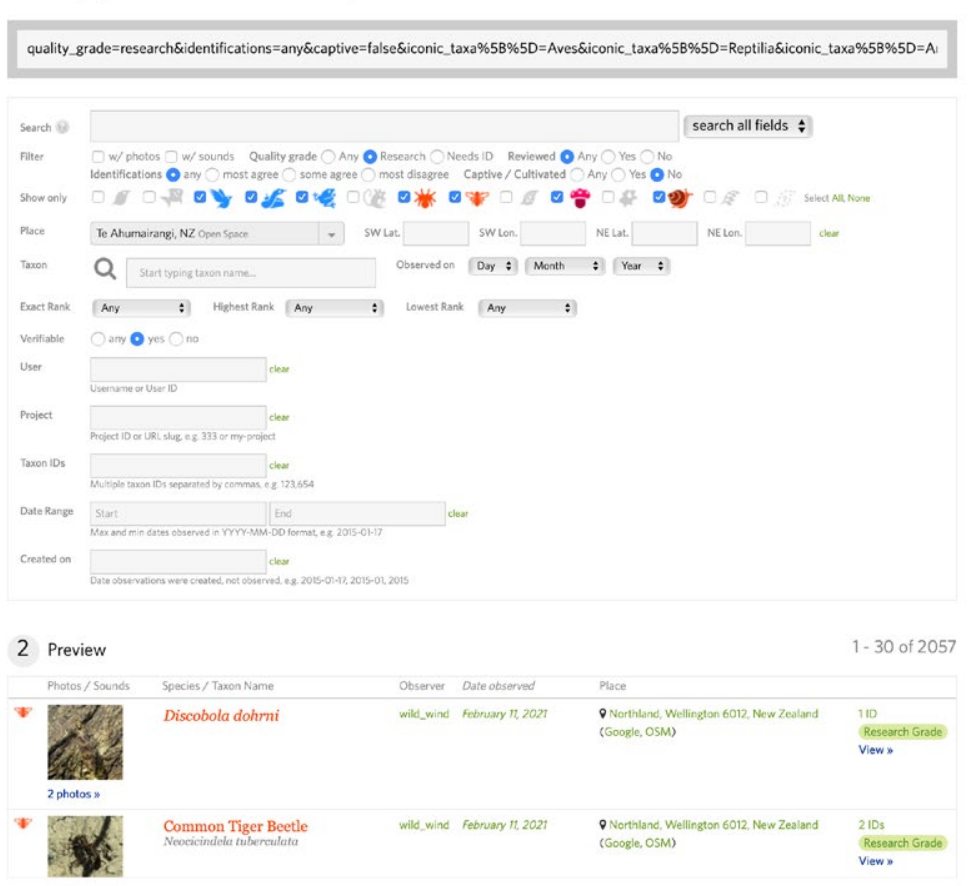

and reports of the species of inter

on sile. Then by grouping these

organisms into defined habitats

af understanding of the overlap

of species can be found and their

can be speculated upon.

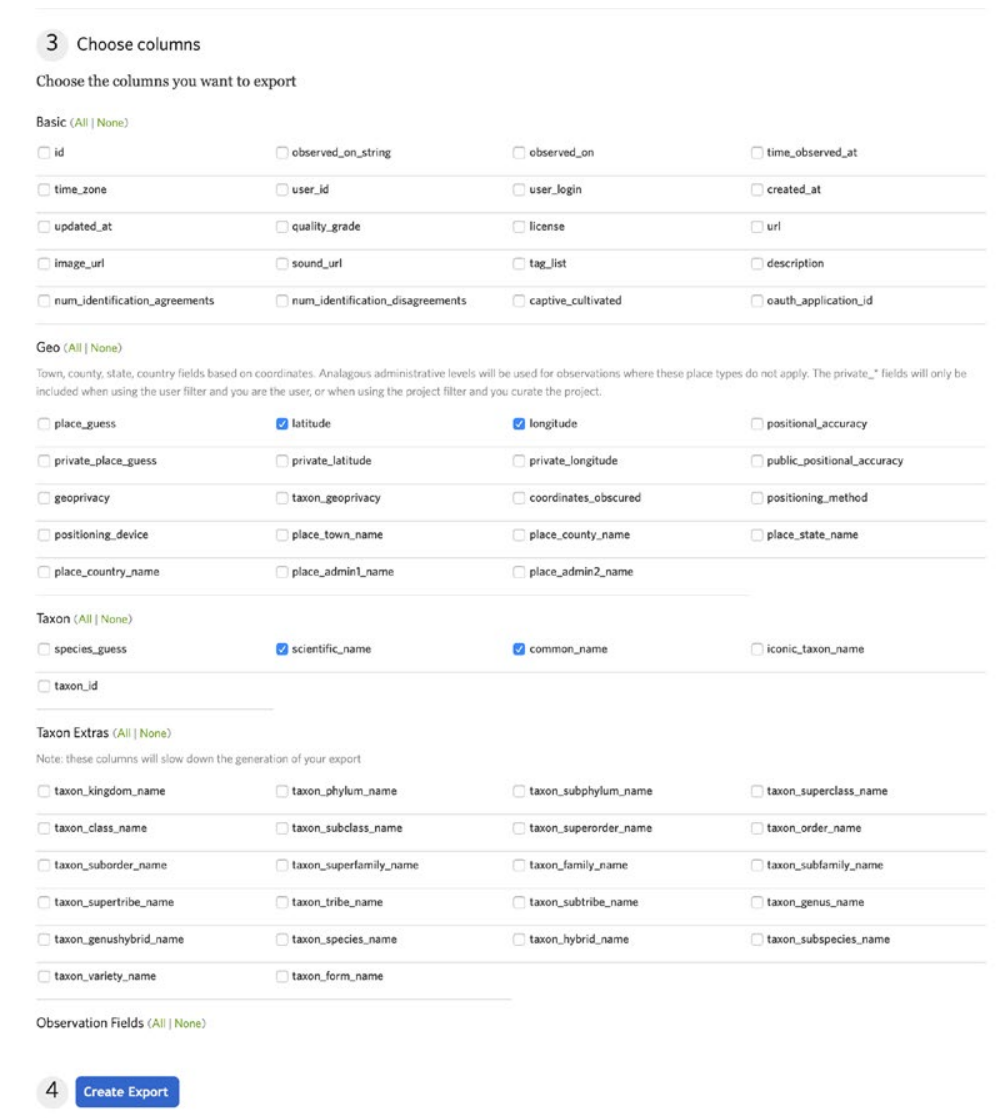

Under the filters tab, is a download feature.

Longitude, latitude are needed for positioning later, scientific and common names for understanding the species. The data is downloaded as .csv file which can be opened with excel.

Using ArcGis, the longitude and latitude data are taken from the .csv, and points are plotted on a map.The symbology layer gives options to group species by colour. 


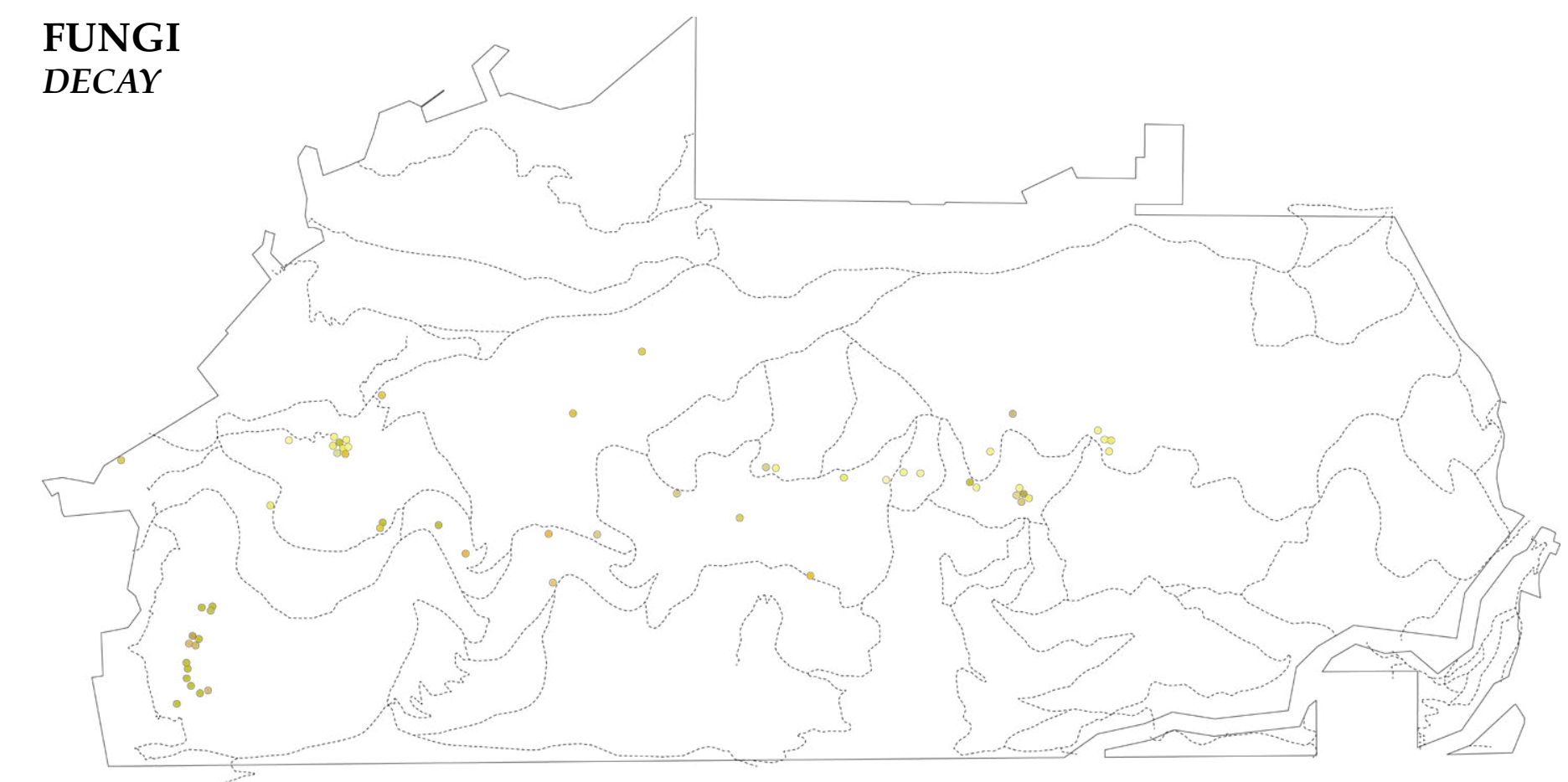

Fungi's role in the ecosystem is to recycle nutrients, they accelerate decay in vegetative matter. As

decomposers in the forest they may

play an important role in natural

experience at the macro-scale.

Ranging in colours from bright red to

blue and in texture from transparent

jelly to hard and woody. They

visually affect the experience of the

forest and might flourish with the

process of burial.

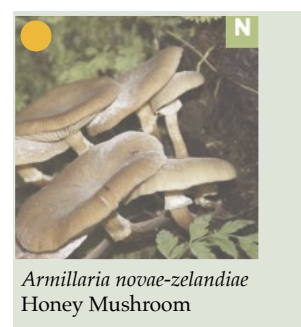

$\underset{\text { Habitat }}{\text { Stumps, Logs, Trees. }}$

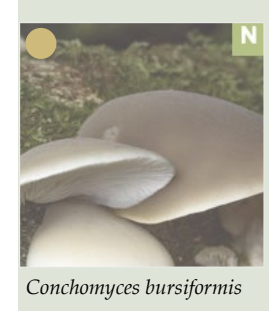

Habitat
Tauav, Beech, Kahikatean.
Pine.
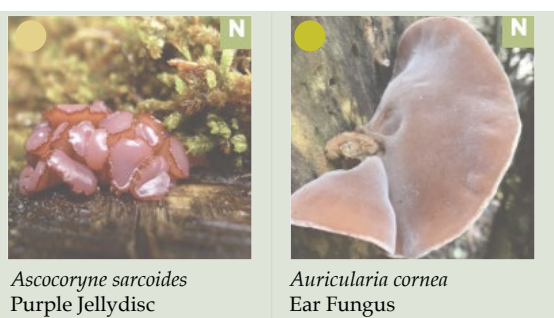

$\underset{\substack{\text { Habitat } \\ \text { Tauo Bech and Pinc }}}{\text { and }}$

Habitat
Mahoo,
Karuaturawa.

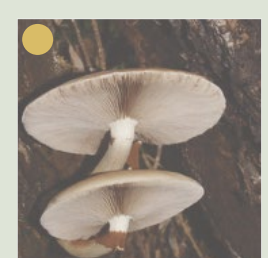

Cyclocybe parasistici

Habitat

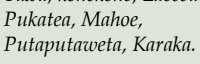
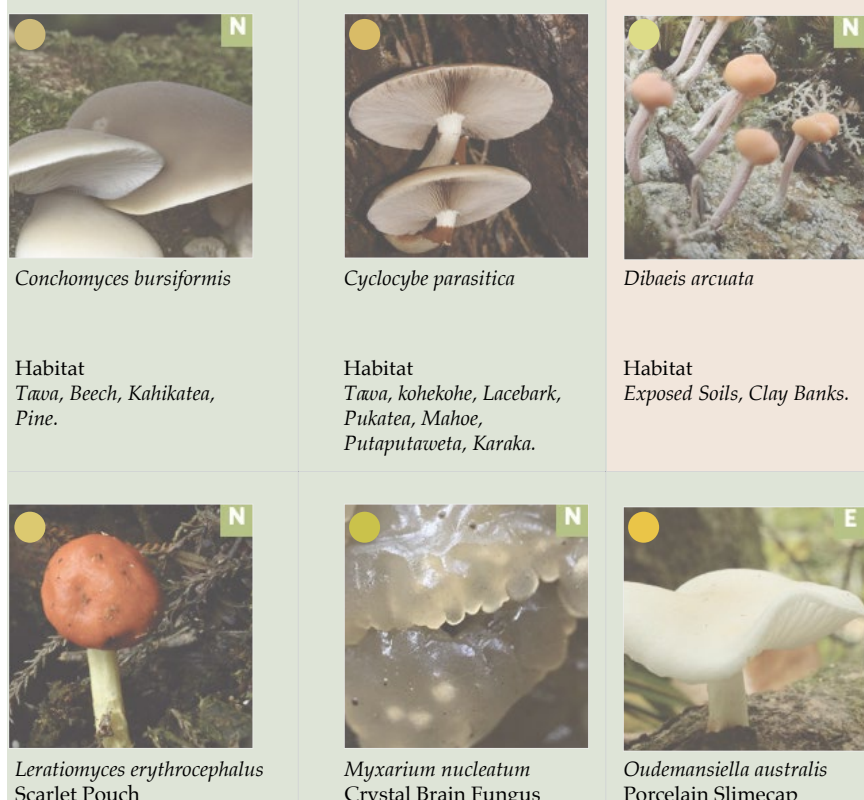

Dibaeis arcuata

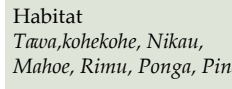

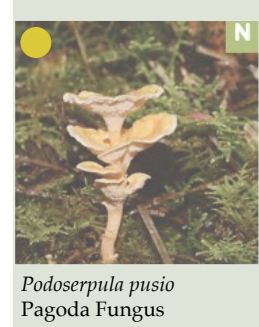

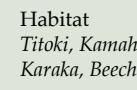

Habitat
Exposed Soils, Clay Ban

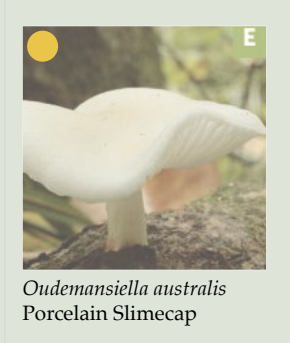

Habitat
Koheche, Mahoe, Mapou,
Beech, Kowhhai.

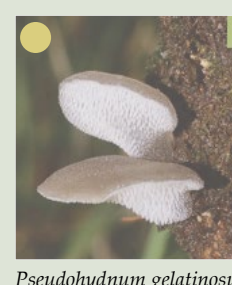

Pseudohydnum gelatinos
Toothed Jelly Fungus

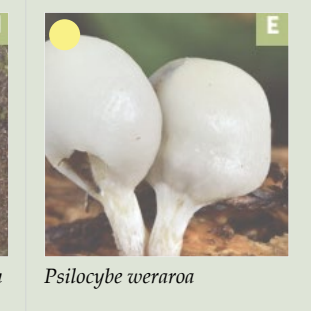

Habitat
Pine, Manuka, Becch, Tawoa.

Habitat
Pine, Manuka, Beed
Tha,

Habitat,
Taua, Bech, Maunka,
Ponga, Mamaku, Karoukarua.
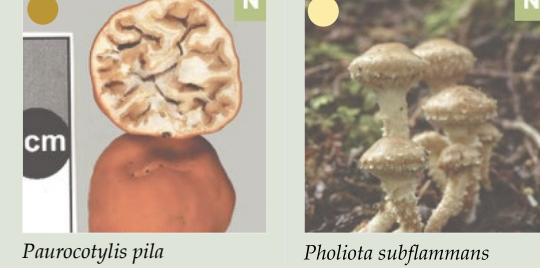

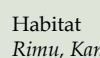

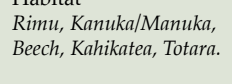

Habitat
Beech, Pine.
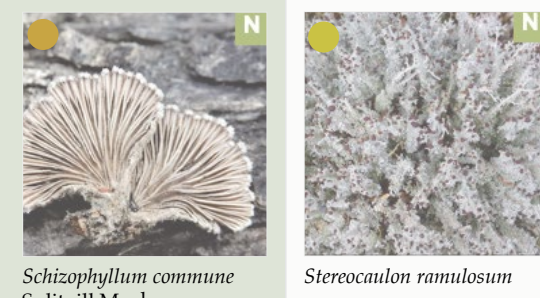

Schizophyllum commun
Splitgill Mushroom$$
\text { sereocan }
$$

Habitat
Pine, Koowhai, Ngaio, Tawou,
Maire.

$\underset{\substack{\text { Habitat } \\ \text { Disturbe }}}{ }$

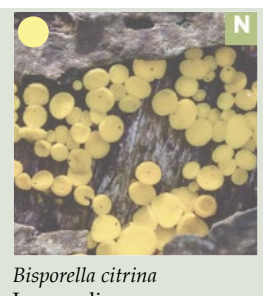

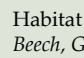

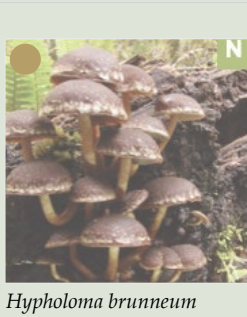

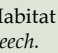

\section{Habitat Key}

Decaying Wood

Rocks

Dry Banks

Damp Banks and Caves

Standing Water

\begin{tabular}{l|l}
$\begin{array}{l}\text { Habitat } \\
\text { Trua, Manukla, Mamaku, } \\
\text { Becch. }\end{array}$ & Shrubland \\
\hline
\end{tabular}

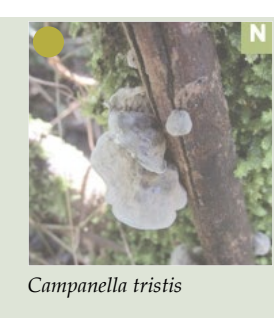

Habitat
Coastal Forses Species.

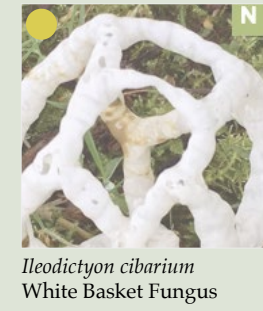

$\underset{\substack{\text { Habitat } \\ \text { Pine, Kanuka, Mamaka }}}{\text {. }}$

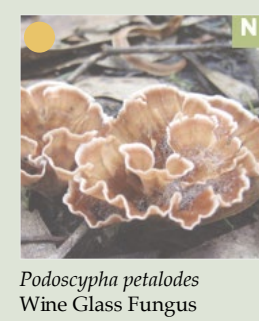

Habitat
Pine, Kanuka, Puktatea,

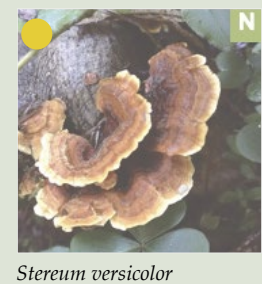

Stereum versicolor
False Turkey-tail

Habitat
Tauva, Kohkekhe, Reverewewa,
Manuka, Kahikatea, Beech. 


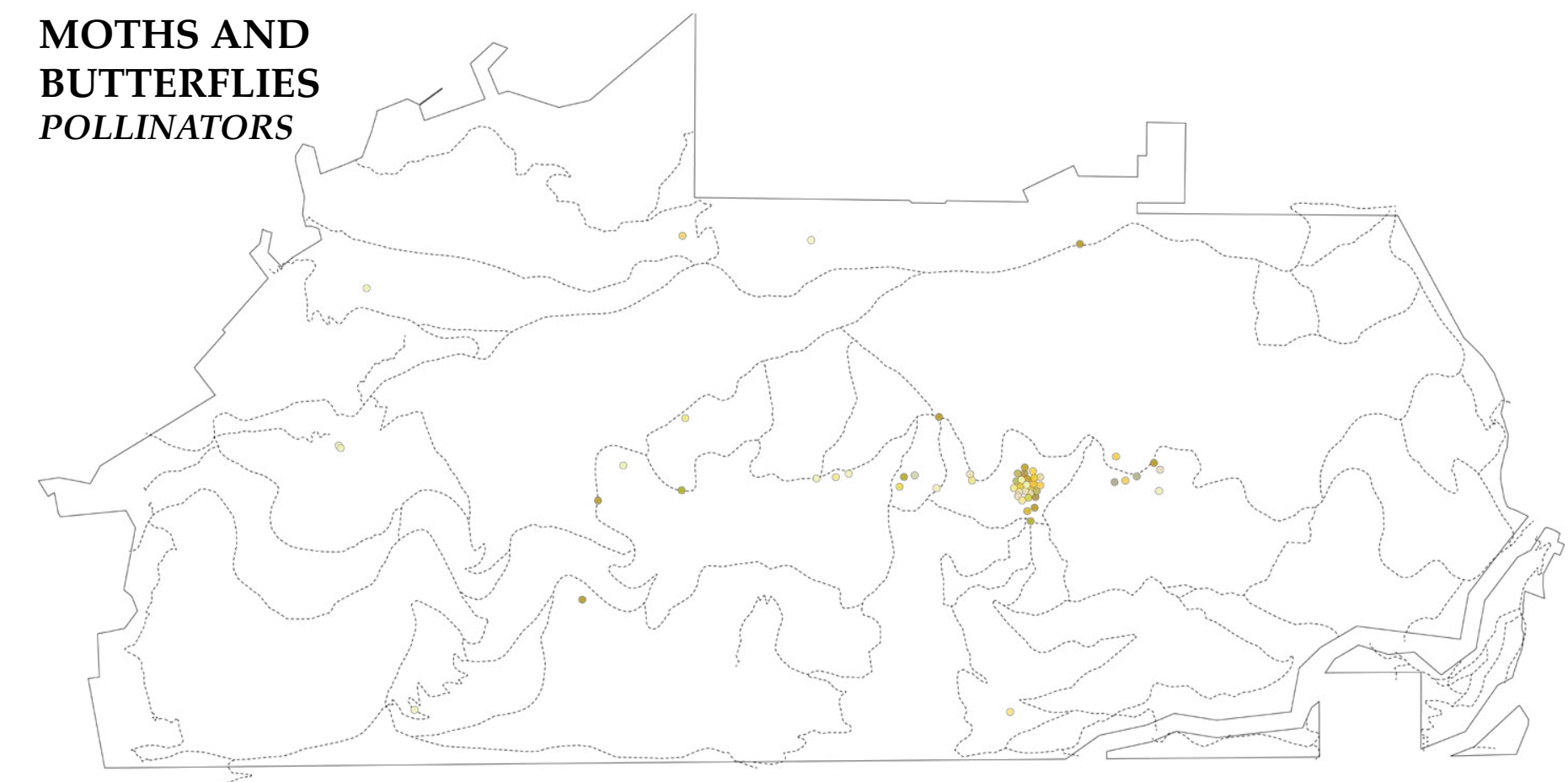

Moths and butterflies play important roles in the pollination of plants and for birds.

Many of these members of the Lepidoptera insect order have

specific relationships with plants like the flax notcher, kawakawa looper, clematis triangle and many others.

The planting of thousands of native species in tandem with natural burial
would likely increase the populations of these insects, in turn benefiting birds. Increased sightings of them might help to heighten the sense of the interconnectedness of living of dying

dying, in a cemetery context.

Habitat Key Decaying Wood

Rocks Dry Banks Damp Banks and Caves Standing Water Shrubland Forest

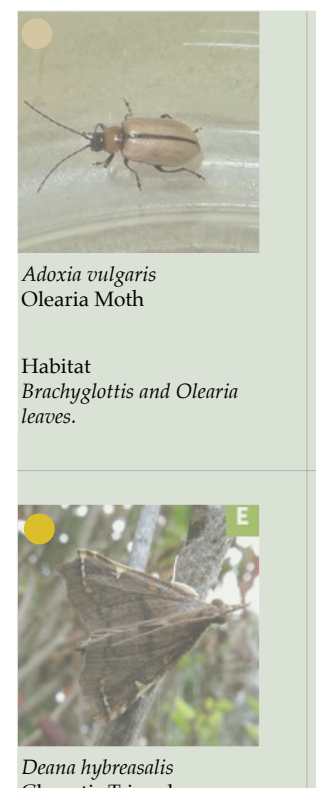

Clematis rianng

Habitat
Clematis leav

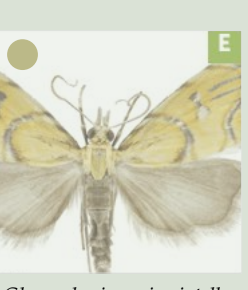

Glaucocharis auriscriptella
Moss Moth

$\underset{\substack{\text { Habitat } \\ \text { Feeds on mosses. }}}{\text {. }}$.

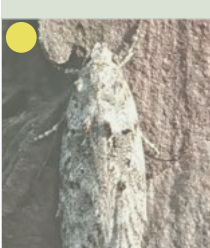

Izathac onvulsel
Rimu Moth

Habitat
Rimu, lichen,

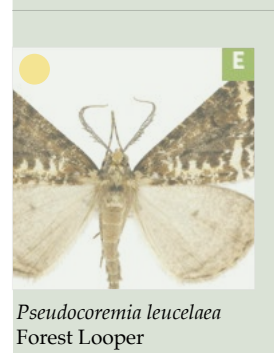

Pseuddocoremia lencect
Forest Looper

Habitat
Pinit, imu, Miro and
Totarn leares

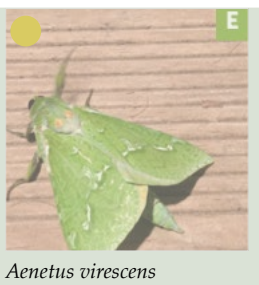

Aenerths virescens
Puriri Moth

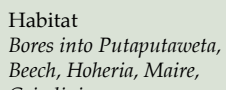

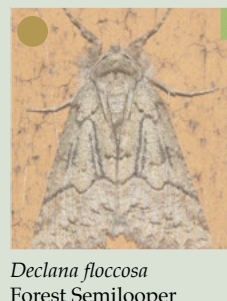

Habitat
Pine and Muehlenbeckia
Leves.

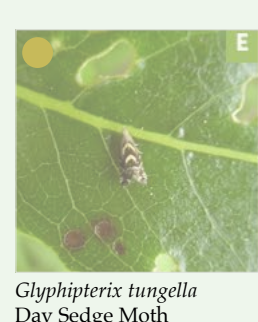

Sedgestat in open habitits

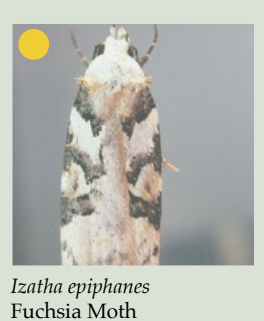

$\underset{\substack{\text { Habitat } \\ \text { Fuchsiand }}}{\text { and }}$

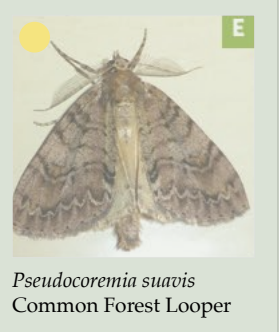

Habitat
Pine, Rimu, Miro and
Totarar, Bech, Kanu

Habitat
Hydrocotle leaves.

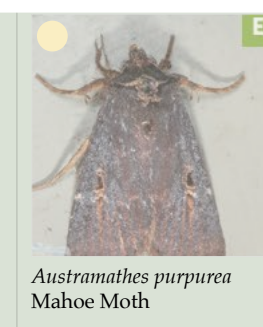

Habitat
Matho leaves

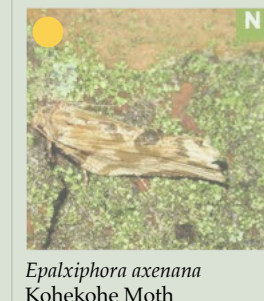

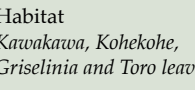

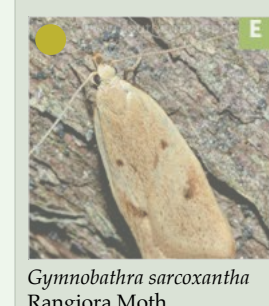

Habitat
Rangiorar leaves.

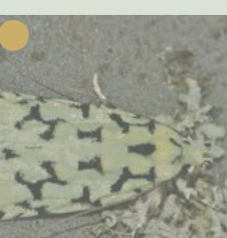

atha huttonii
Wineberry Mot

Habitat
Winebery and Kara
dead woood.

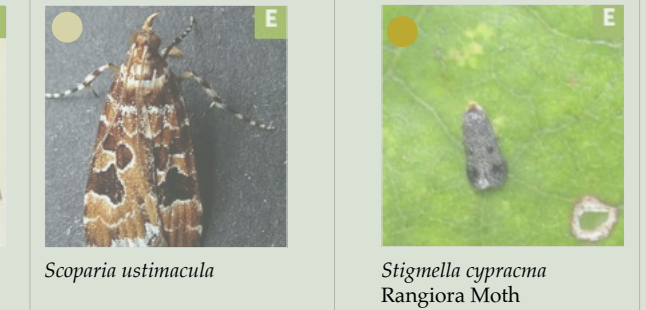

Stigmella cypracn

Habitat
Rangiora lenves

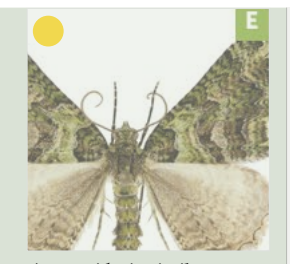

Austrocidaria sisilitata
Dark Coprosma Moth

Habitat
Coprosma robusta,
rotundifflia

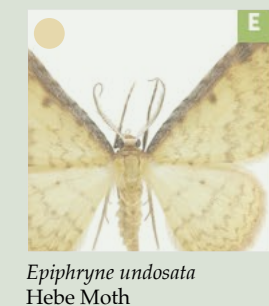

Habitat
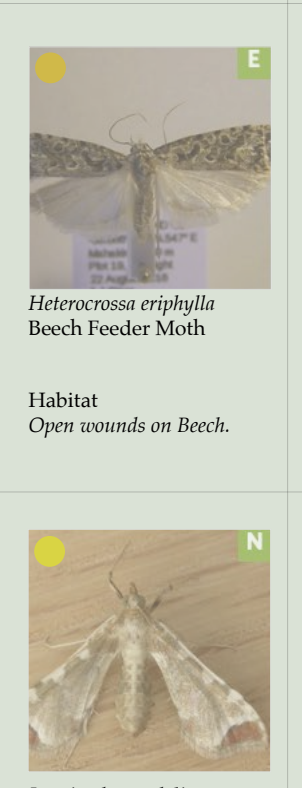

Leucinodes cordalis
Poroporo fruit Borer

$\underset{\substack{\text { Habitat } \\ \text { Poroporof fruit. }}}{\text {. }}$

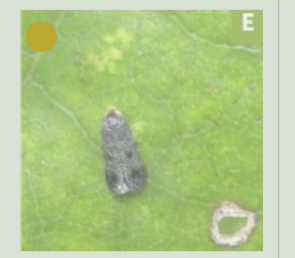

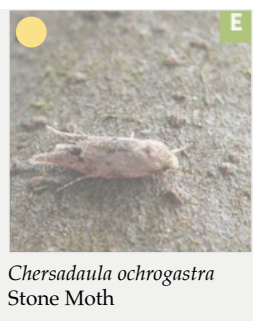

Habitat
Under stones.

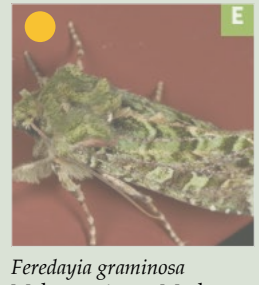

Habitat
Mahoe laveres.

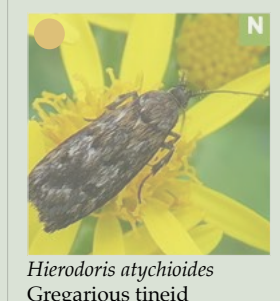

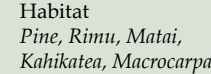

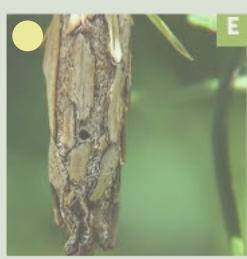

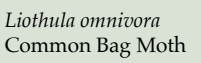

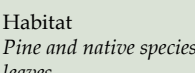

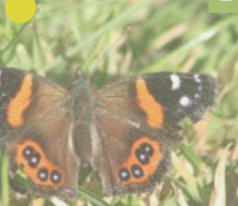

Vanessa gonerilla

Habitat
Ongaong a nettle) leard

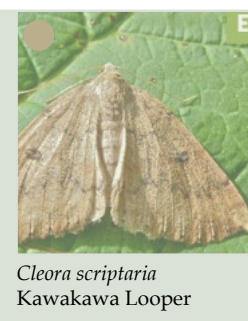

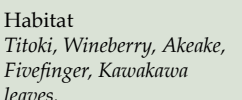

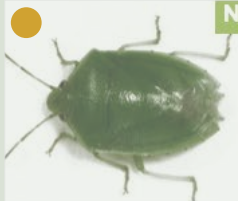

Clackicis anyotii
Australasian Shield Bug

Cabitite
Coprosman, Griselinia and
Nogio leaves.

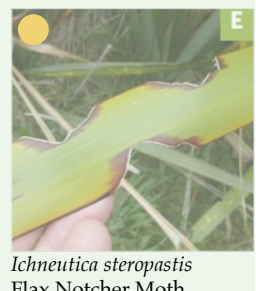

Habitat
Flax lenves
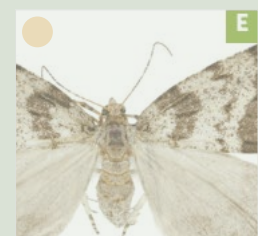

Pseudocoremina fenerata
Conifer Moth

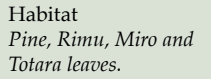

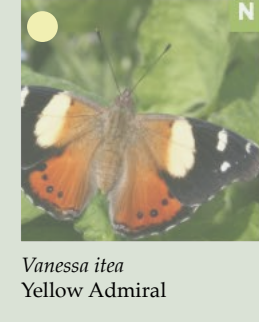

Habitat
Ongoonga (nettle) leaves. 


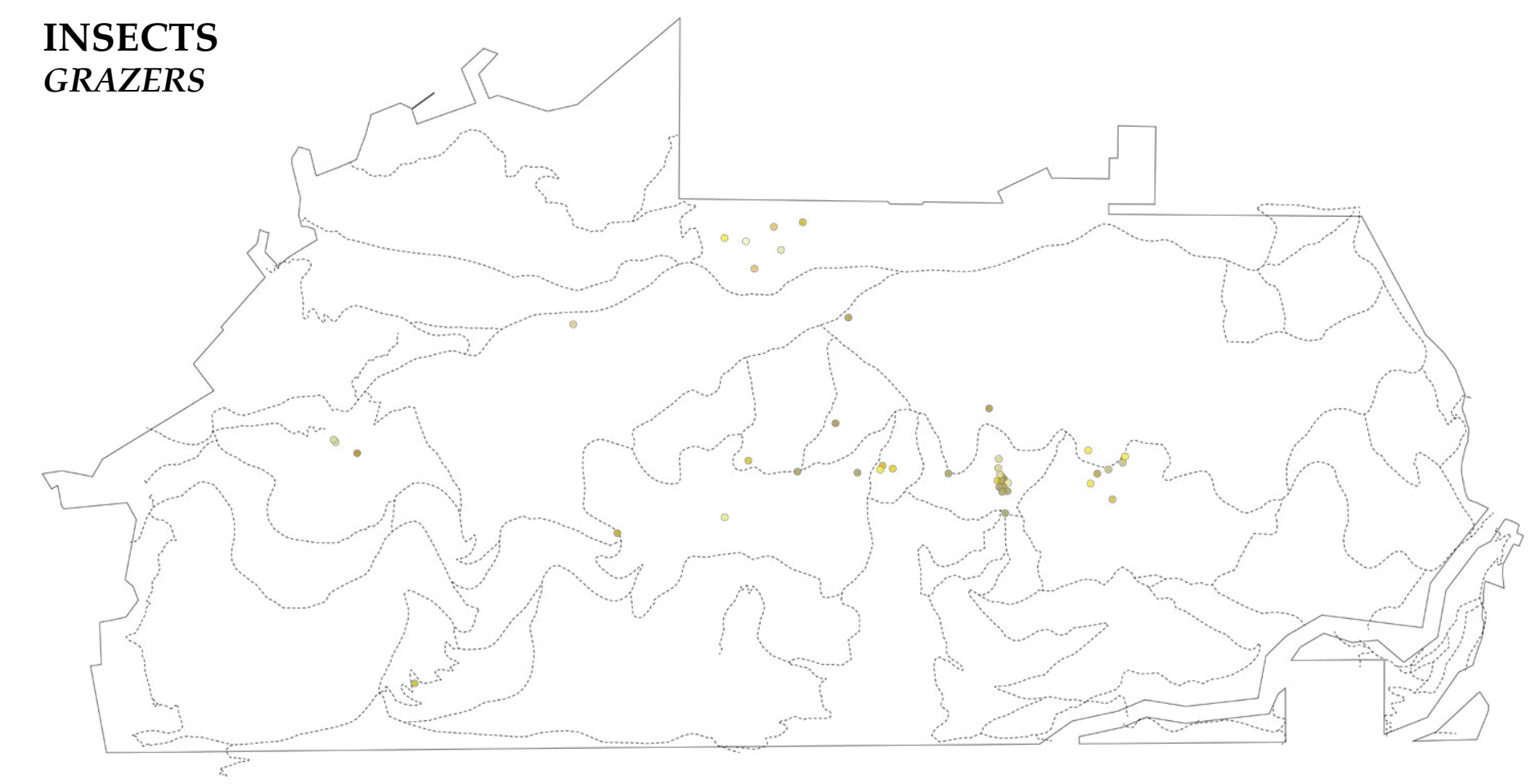

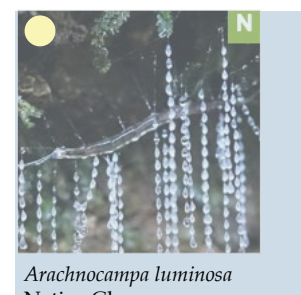

Arachnocampa luminosa
Native Glowworm

Habitat
Damp, Humid, Caves or
Bun,

$\underset{B a n t}{\text { Dam }}$

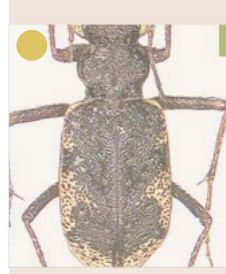

Neocicindela parryi
Parry's 'Tiger Beetle

Habitat
Dry Clay Banks

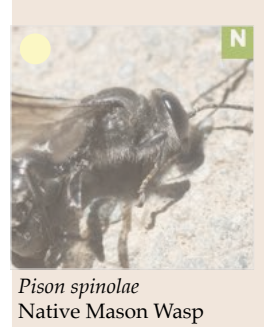

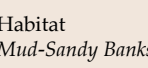

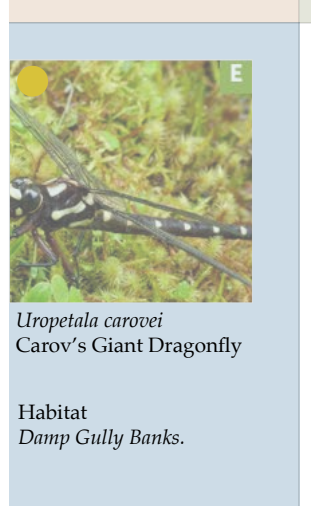

Habitat Key

Decaying Wood

Rock

Dry Banks

Damp Banks and Caves

Standing Water

Shrubland

Forest

\section{$x+\sqrt{2}$}

Argosarchus horridus
Native Ciant Stsick losect

Habitat
Bush Lacuyer, Myrtles,
Hoheria

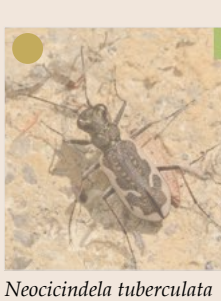

$\underset{\substack{\text { Habitat } \\ \text { Dry clay Banks }}}{\text {. }}$

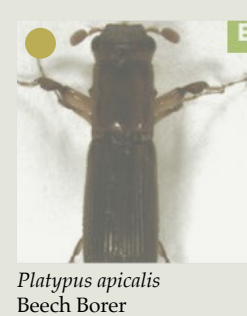

Habitat
Decaying
Wood.

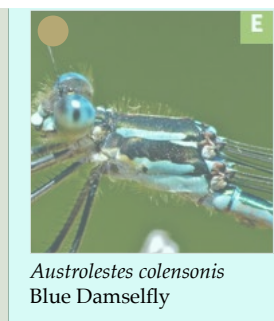

Habitat
Ponds 1m deep, Wetland
plants.

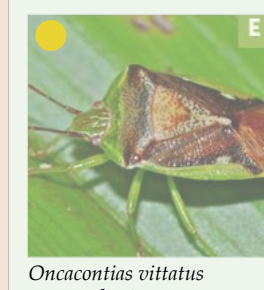

Forest Shield BuSG

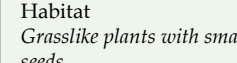

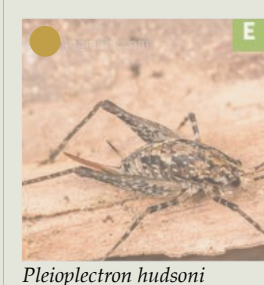

Pleiplectron hudsoni
Tokoriro/Cave Weta

Habitat
Leaf litter
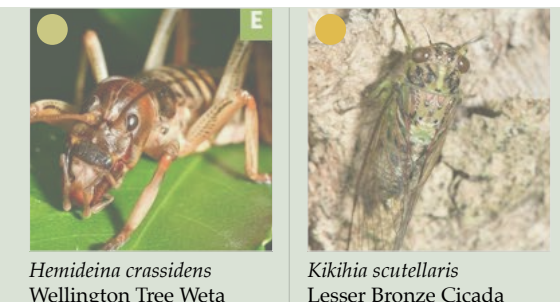

Habitat
Holes in living Manukal
Kanuka, Ngaio, Kohekohe,
Maroee

$\underset{\substack{\text { Habitat } \\ \text { Burrows to 40 cm below }}}{ }$

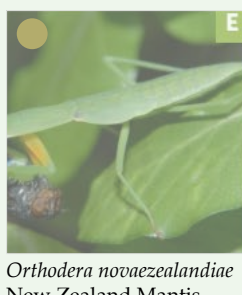

w Zealand Mantis

Habitat
Open Shrubland, Mannkal,
Kanuka, Eats mothsfflies.

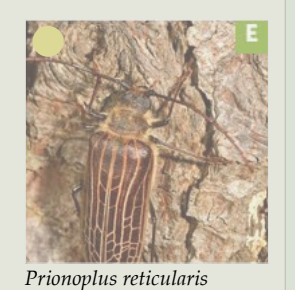

Primonolls reticul
Huhu Beetle

$\underset{\substack{\text { Habitat } \\ \text { Bark of Fallen }}}{\text { Wot }}$

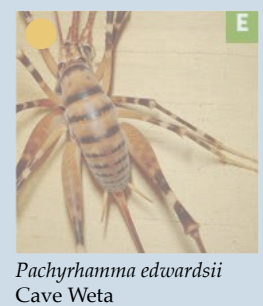

Habitat

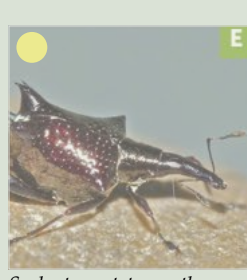

Scolppterus tetracanthlus
Four-spined weevil

Habitiat
Flovers of Nikau, Hoheriu
Scheffera.

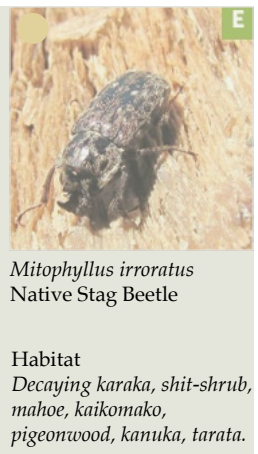

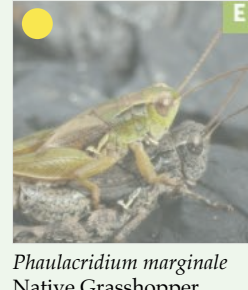

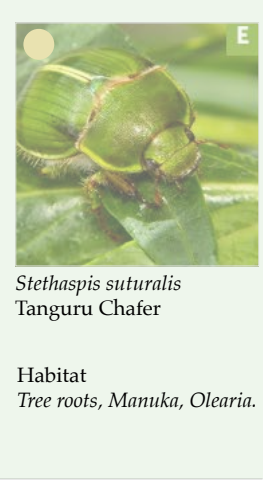


BIRDS

DISPERSAL

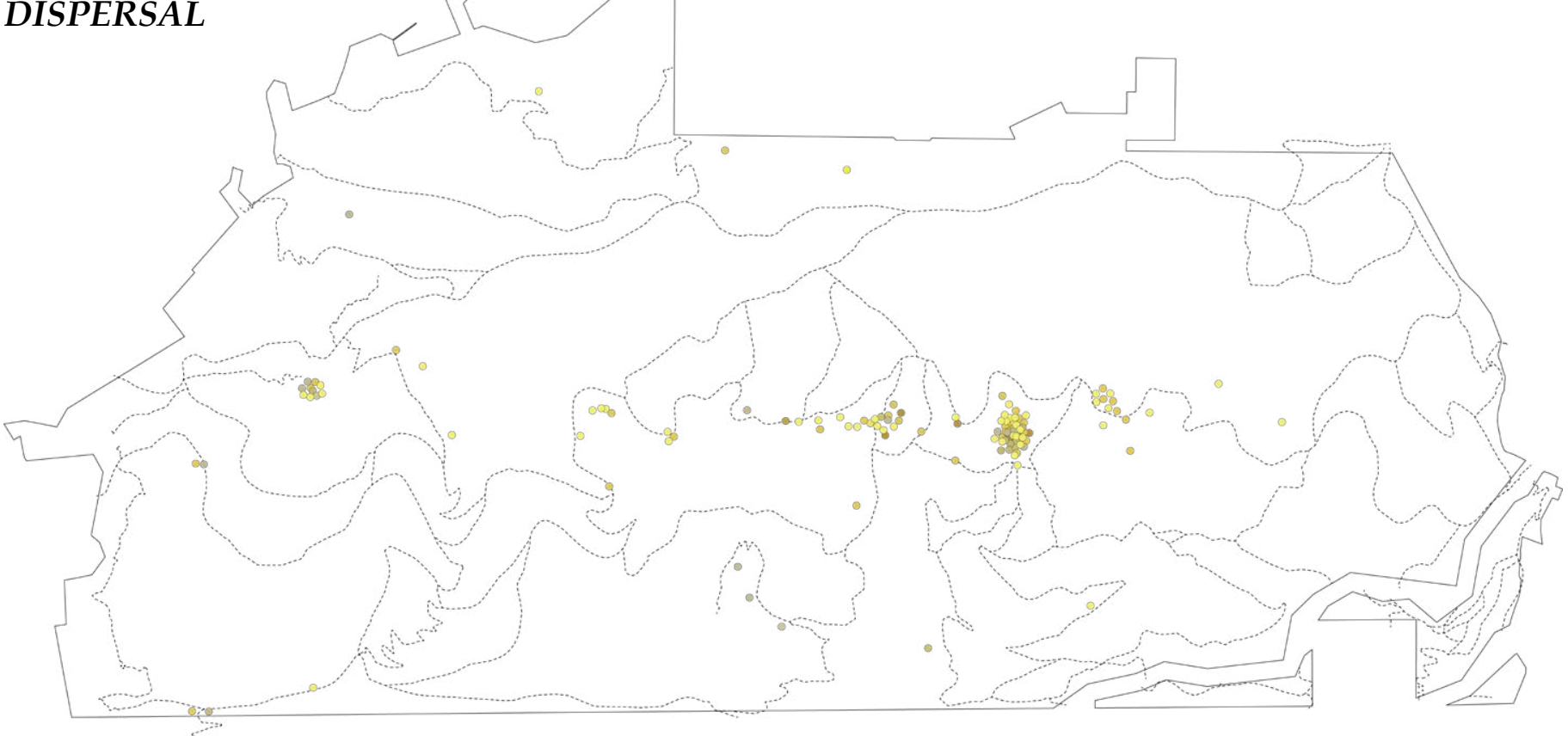

Birds are the most visible and widely loved animals. Their songs and interactions are a favourite experience of many. There isn't a large diversity of native birds at Te Ahumairangi, but increasing mature native plants and trapping would bring more.

As the top of the food-chain (not including introduced mammals) in Telth and popultionefit from the food sources. Burial methods could increase those which in turn will benefit birds.

\section{MOLLUSCS}

GRAZERS

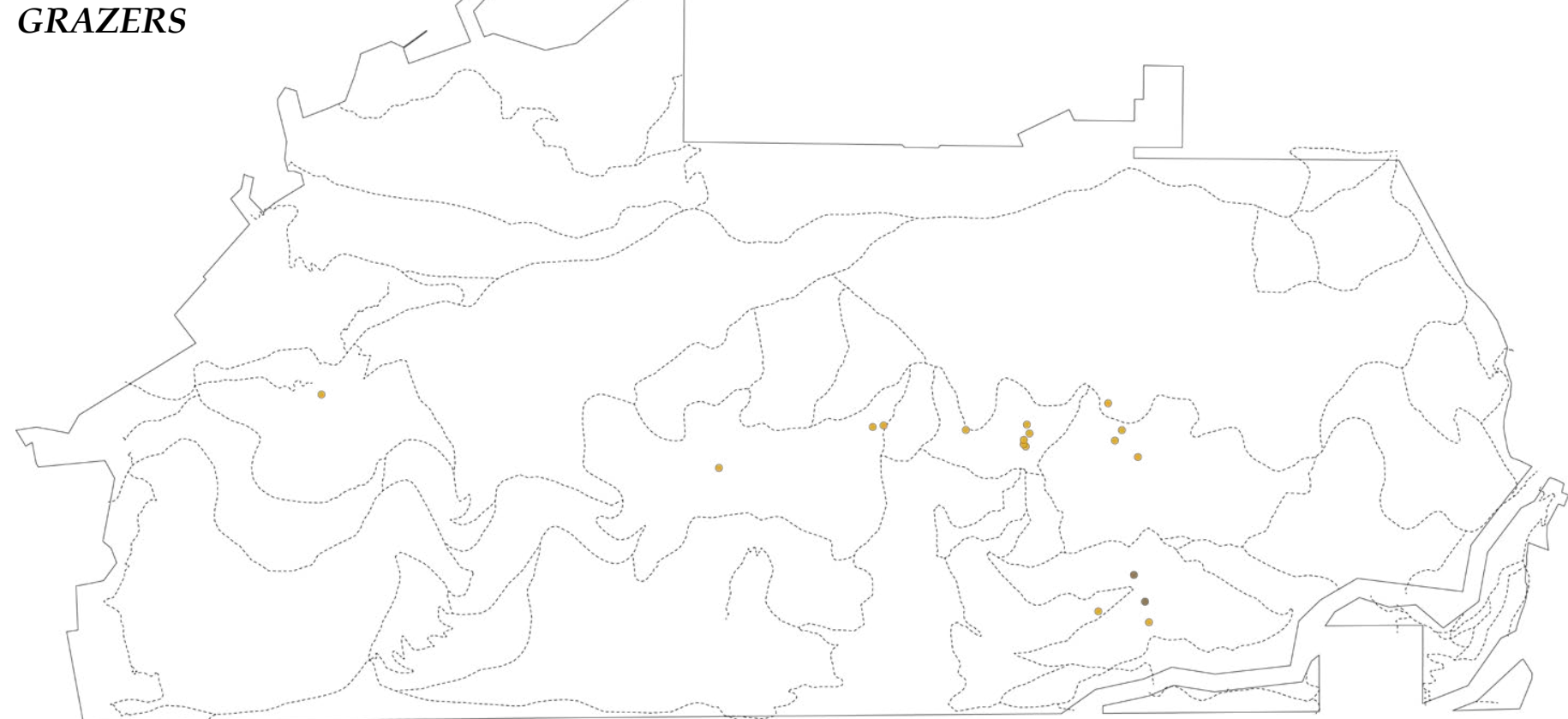

There are just two recorded native molluscs from Te Ahumairangi

Potamopyrgus oppidanus is particularly unique because its only habitat is a

small stream on Te Ahumairangi. It is critically threatened and options for its protection should be explored.
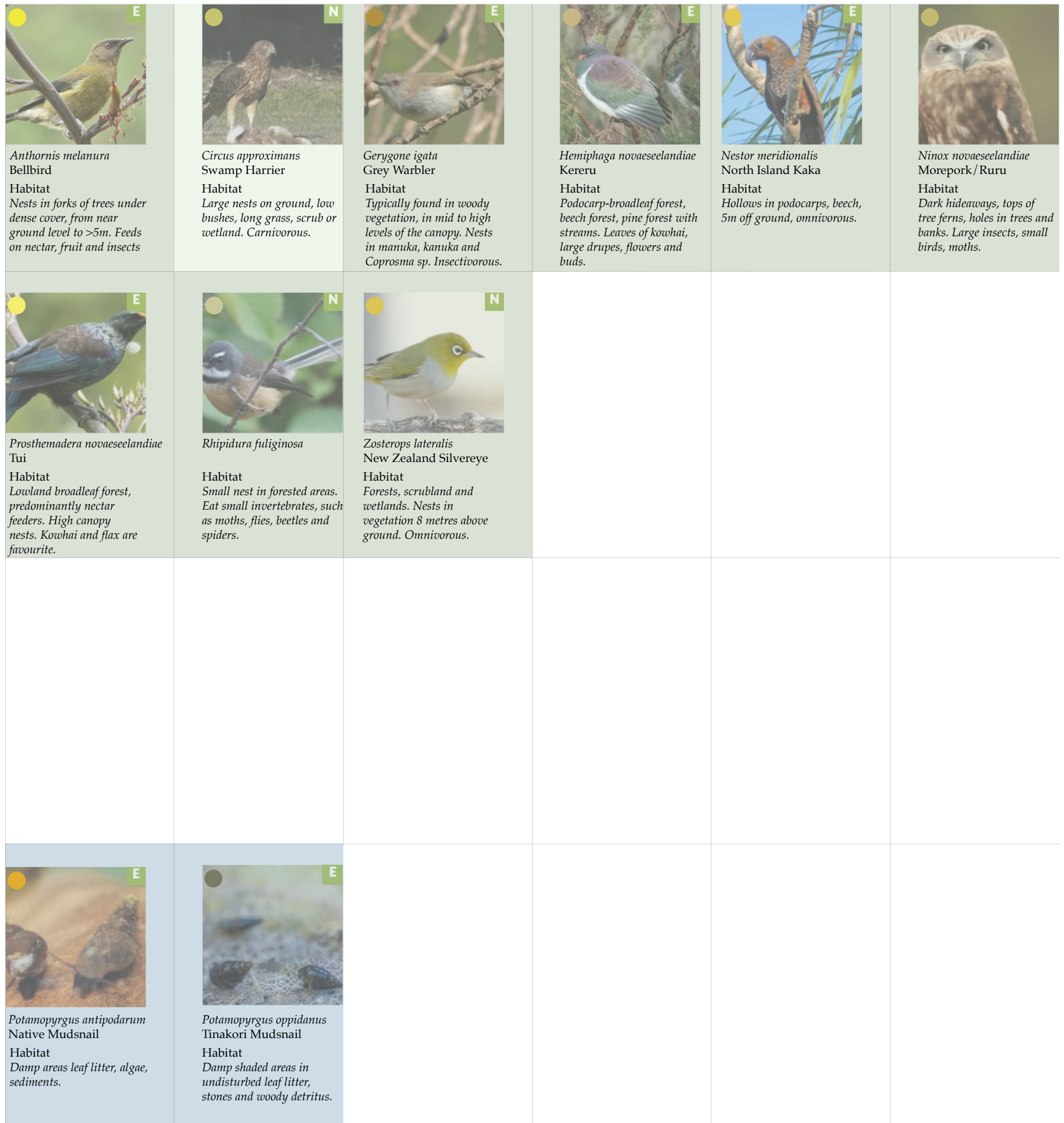

\section{Habitat Key}
Decaying Wood
Rocks
Dry Banks
Damp Banks and Caves
Standing Water
Shrubland
Forest 


\section{Chapter Five - Regional Landscapes}

\section{Fieldwork}


ECOLOGIES SURROUNDING

TE AHUMAIRANGI

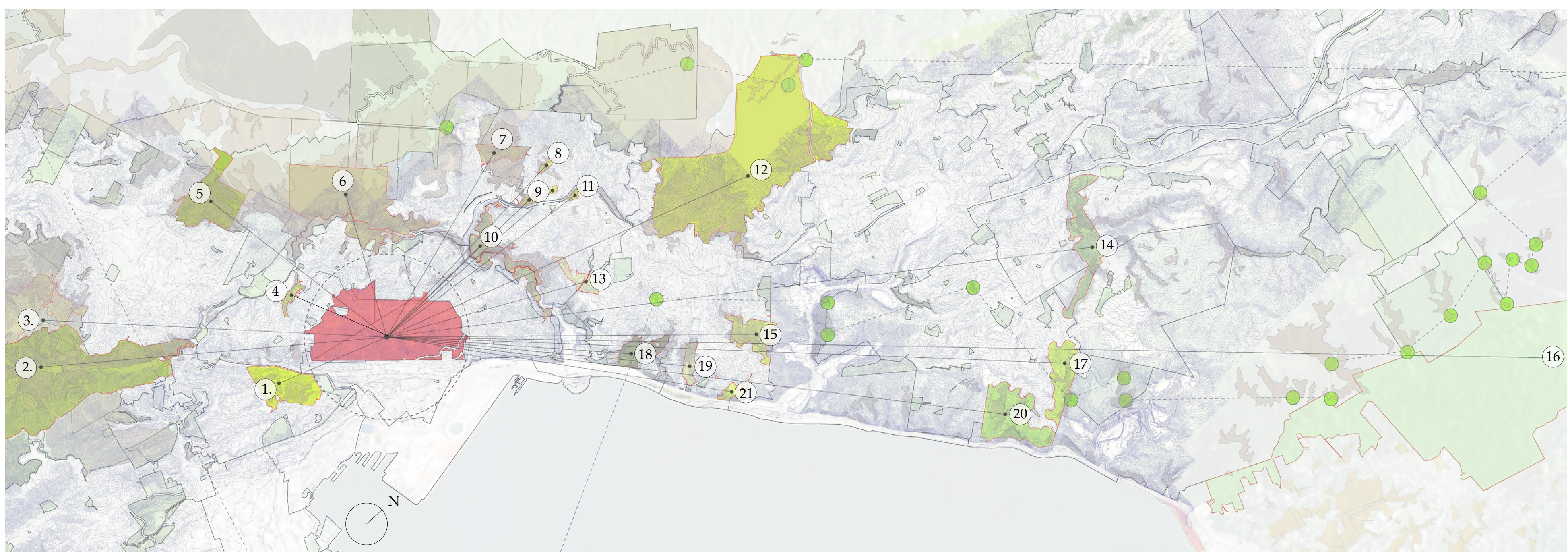

\section{Visits}

An ambition of visiting twentyone different reserves was set to understand the surrounding ecological context. In total the fieldwork, amounted to walking $60 \mathrm{~km}$ (roughly the distance from Wellington to Otaki) and nearly 24 hours of non-stop walking.

Two thirds of the outlined reserves were visited and I decided I had enough material to work with. Some areas I had already been to and Another two areas not within the original bounds of investigation but were significant include Paekakariki Escarpment and Te Kopahou Reserve.

\section{Reason}

While Te Ahumairangi does have a range of native forest species, from a century of farming and exo plantations. Lots of species that will grow here given time, are absent. It was also important to understand how as the forest ages, different spatialities will occur.

\section{Text Key}

Visited

Visited Before

Did Not Visi

\section{Map Key}

$\square$ Reserves

Te Ahumairangi

Mature Nikau Sites
Surrounding Sites

1. Botanic Gardens

2. Zealandia

4. Albermarle Reserve

5. Johnston Hil

6. Otari Wilton's Bush

7. Huntleigh Park

3. Orleans Reserve

10. Trelissick Park

11. Cummings Park 12. Mt Kaukau

14. Seton Nossiter Park

5. Tyers Stream Reserve 16. Belmont Park 18. Kaiwharawhara Park 19. Cashmere Park 20. Te Ara Paparang 21. Homebush Park 


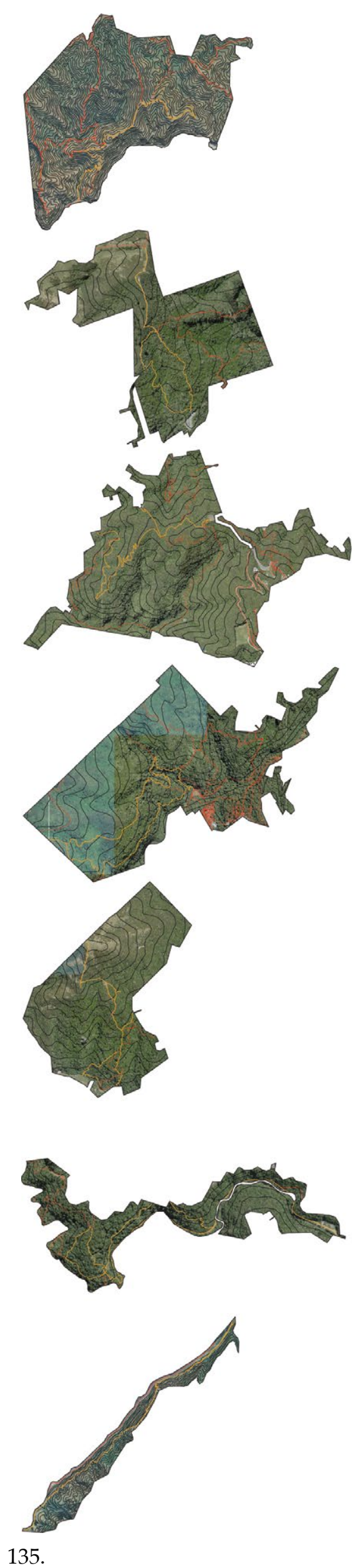

$\begin{array}{ll}\text { Pariwhero Loop Track } & \text { Experience and Findings } \\ \text { D: } 9.3 \mathrm{~km} & \text { A range of threatened species } \\ \text { T: } 3 \mathrm{~h} 15 \mathrm{~m} & \begin{array}{l}\text { including Cook Strait kowhai, } \\ \text { leafless Clematis, leafless lawyer and } \\ \text { a range of scrub communities useful } \\ \text { in the design of Te Ahumairangi's } \\ \text { ridgleline. }\end{array} \\ \text { Johnston Hill } & \text { Experience and Findings }\end{array}$

D: $1.8 \mathrm{~km}$

T: $1 \mathrm{~h}$

Wrights Hill

Deliverance Track

D: $4.3 \mathrm{~km}$
T: $1 \mathrm{~h} 30 \mathrm{~m}$

T: $1 \mathrm{~h} 30 \mathrm{~m}$

Otari Skyline Track

D: $4.5 \mathrm{~km}$

T: $1 \mathrm{~h} 45 \mathrm{~m}$

Huntleigh Park

D: $1.5 \mathrm{~km}$

$\mathrm{T}: 1 \mathrm{~h}$

\section{Trelissick Park}

D: $4.1 \mathrm{~km}$

T: $1 \mathrm{~h} 10 \mathrm{~m}$

Paekakariki Escarpment Track

\section{D: $9.8 \mathrm{~km}$}

T: $3 \mathrm{~h} 20 \mathrm{~m}$

Old karaka groves, kohekohe, ngaio
and kawakawa forest on scree slopes.

Experience and Findings

Clusters of remnant rimu and kohekohe. Healthy populations of rewarewa.

\section{Experience and Findings}

Large kahikatea, matai and totara podocarp forest, with a rich fern understory.

\section{Experience and Findings}

Old karaka groves and broadleaf forest.
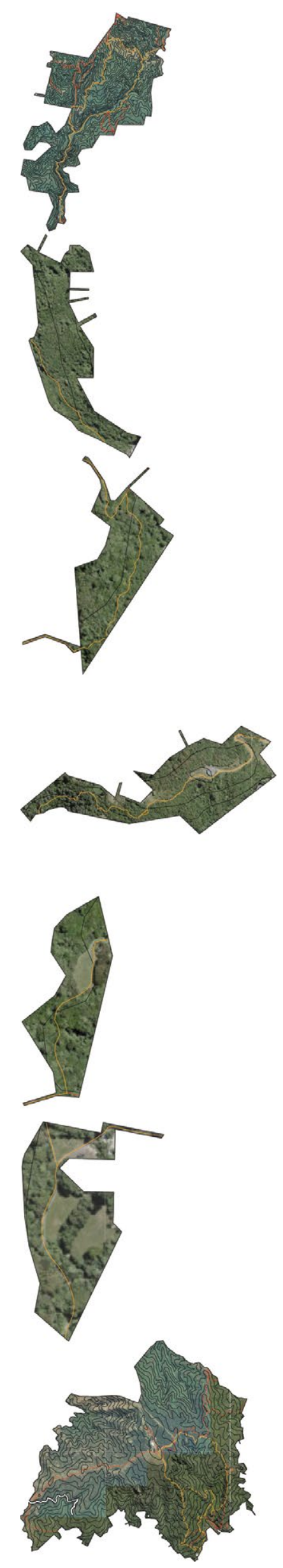

Belmont Trig-Korokoro Track Experience and Findings

D: $16 \mathrm{~km}$

Podocarp forests with high proportion of Nikau. Beautiful shrubla horopito, rauk hupiro, horopito, raukaua, griselinia, of Te Ahumairangi's ridgeline. Experience and Findings

\section{Albemarle Reserve}

D: $0.7 \mathrm{~km}$

T: $20 \mathrm{~m}$

Heke Reserve

D: $0.4 \mathrm{~km}$

T: $15 \mathrm{~m}$

Odell Reserve

Piwakawaka Track

D: $2 \mathrm{~km}$

T: $30 \mathrm{~m}$

Orleans

Pukatea Walk

D: $0.7 \mathrm{~km}$

T: $20 \mathrm{~m}$

Cummings Park

D: $0.4 \mathrm{~km}$

T: $15 \mathrm{~m}$

Mount Kaukau Loop

D: $4.2 \mathrm{~km}$

T: $1 \mathrm{~h} 20 \mathrm{~m}$
A tributary of Te Ahumairangi.

Regenerating mahoe, ponga and tree

Experience and Findings A few very old ngaio.

Experience and Findings

Largely dominanted by exotic sycamore, areas of coprosma grandiflora are regnerating underneath.

Experience and Findings

A few large kahikatea, nikau, pukatea and tree fuchsia. Kohekohe and kawakawa forest.

\section{Experience and Findings}

One very old totara and interesting planted specimens like Nestegis
lanceolata.

Experience and Findings

Raukaua edgerleyi and raukaua anomalus with some beech trees. 


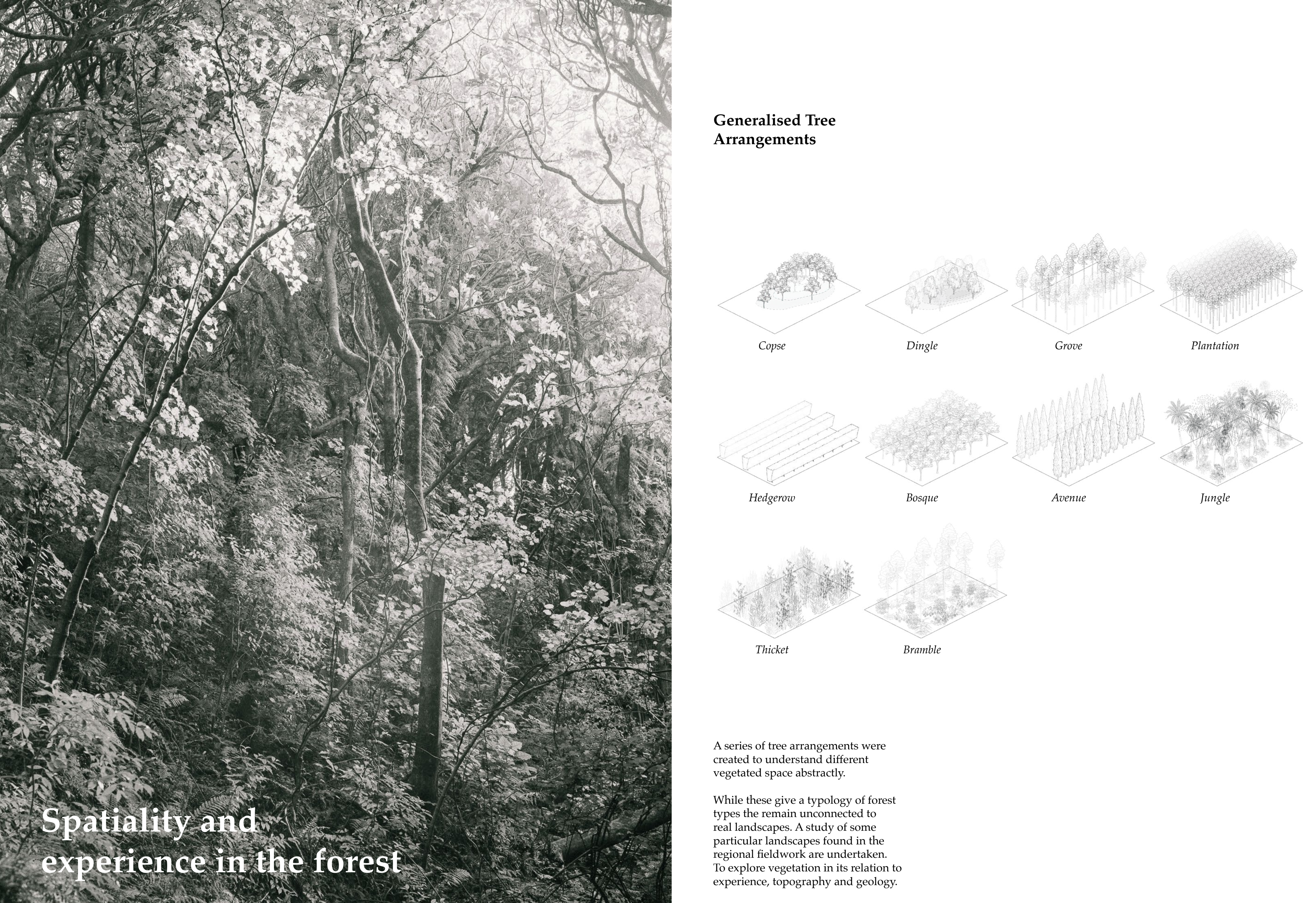


Johnston Hill Twisted Tawa

The northwest-southeast orientation of the ridgeline, leaves tawa trees

open to the strong winds. The main leading trunks snap, causing the trees to develop twisted candelabra-like forms, as secondary leaders grow

This copse of tawa illustrates how individual trees could act as marker for the dead in a greater collective. The growth forms are highly unique and recognisable further to unique visitor has to duck or bow (somewhat reverentially) to move beneath the low limbs. After initial viewing of up the multitude of small branches, toward the lightness of the canopy and sky.

To achieve this effect, tawa would need to planted in tandem with the deceased, along windy ridgelines.
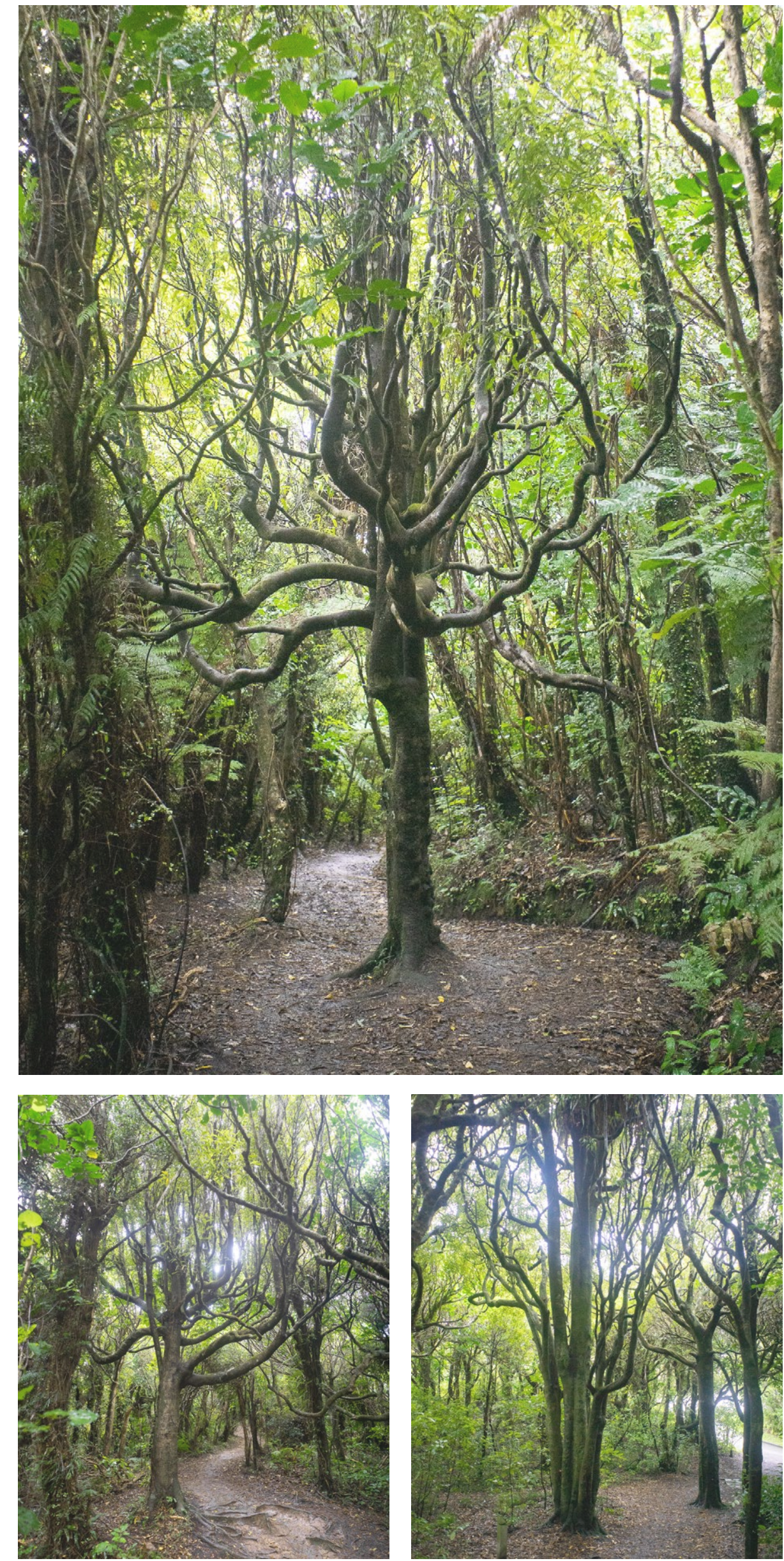

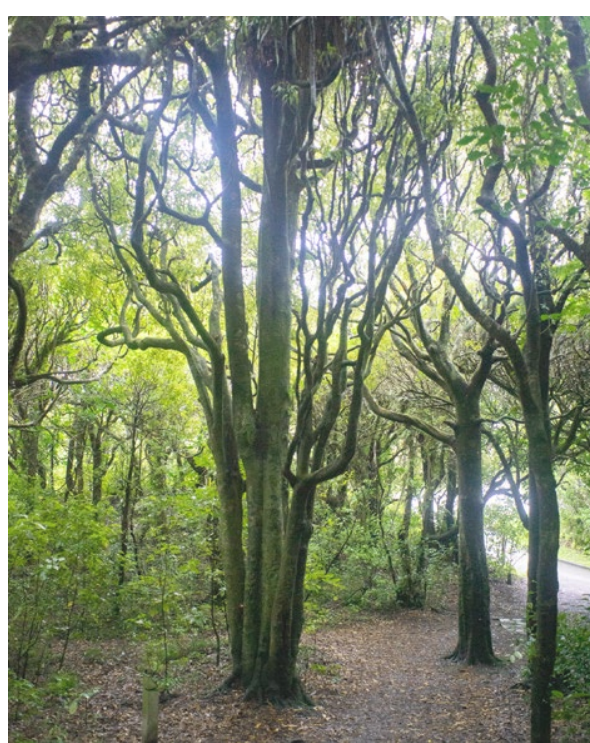

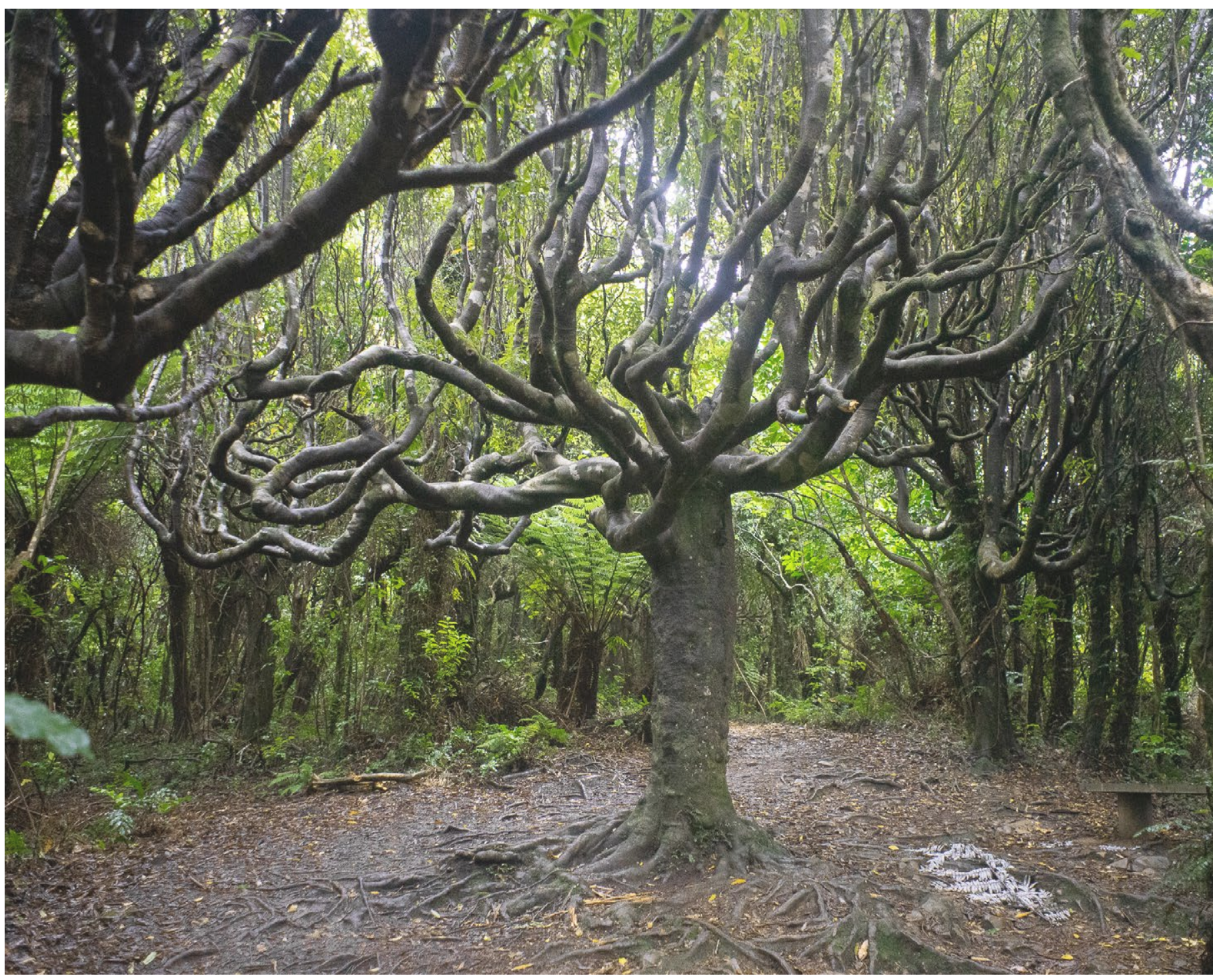

Transect
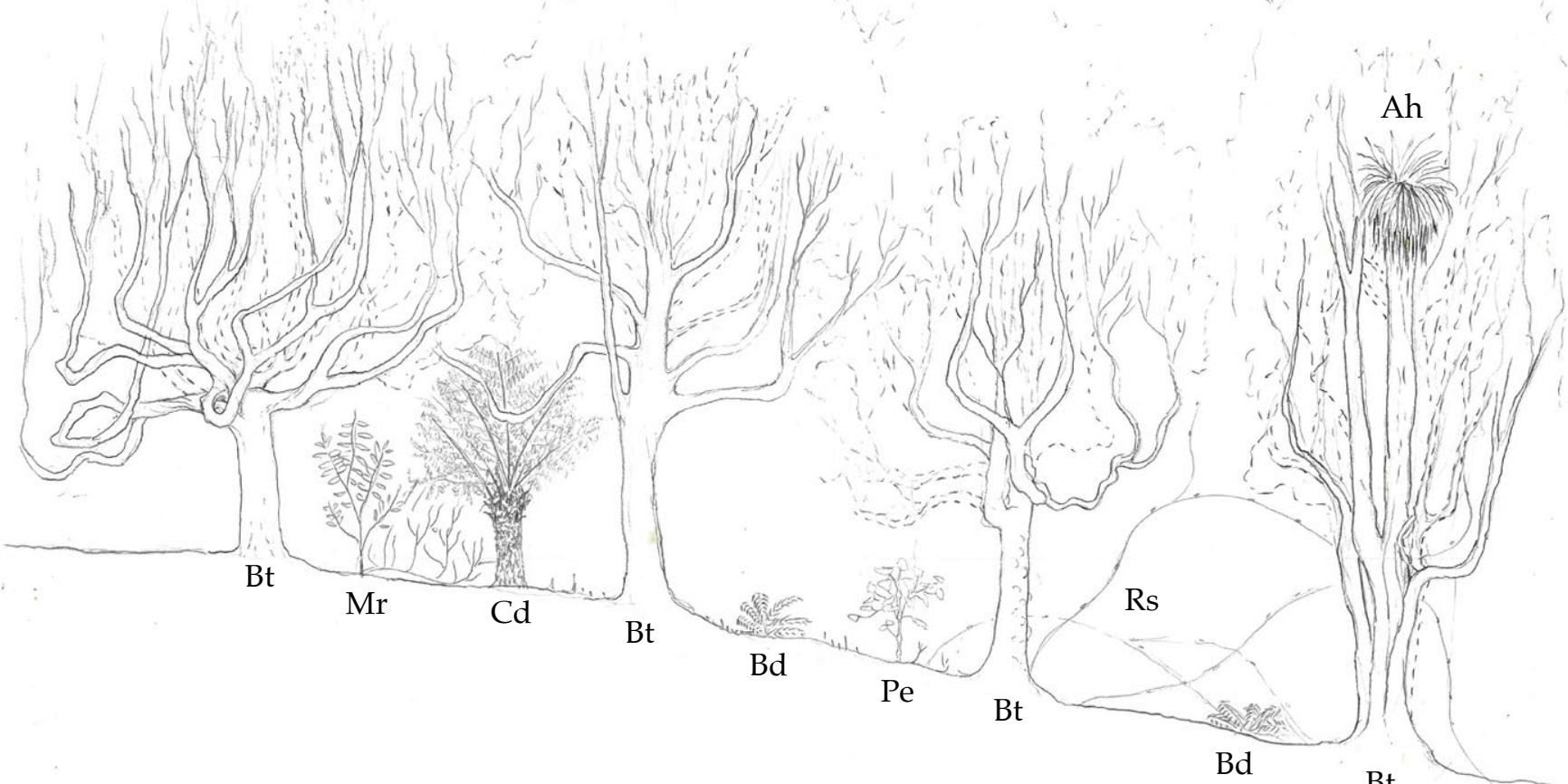

Species present in transect

$\mathrm{Ah}=$ Astelia hastata

Bdechnum discolor

Ponga

Mahoe

$\mathrm{Rs}=$ Ripogonum scanden

Supplejack 


\section{Wright's Hill Mahoe}

A winding, south facing gully where mahoe have grown huge from the available moisture. Their roots act as steps along most of the pathway. Mahoe forest in Wellington tends to have a relatively open understory which makes traversing this forest type relatively easy.

Mahoe form here in what might be termed a dingle or depression. As a be able to see the multitude of life heir loved one supports. Maho's smooth bark often lends itself to colonisation by mosses, then by ferns which turns the trunks a verdant green and lastly, perching epiphytes. wildlife to these small ecosystem may help us to see death as less fin

\section{Species present in transect} $\mathrm{Ao}=$ Asplenium oblongifolium Shining spleenwort $\mathrm{Mr}=$ Melicytus ramiflorus Ms = Microsorum scandens Fragrant fern $\mathrm{Pe}=$ Piper ex
Kawakawa
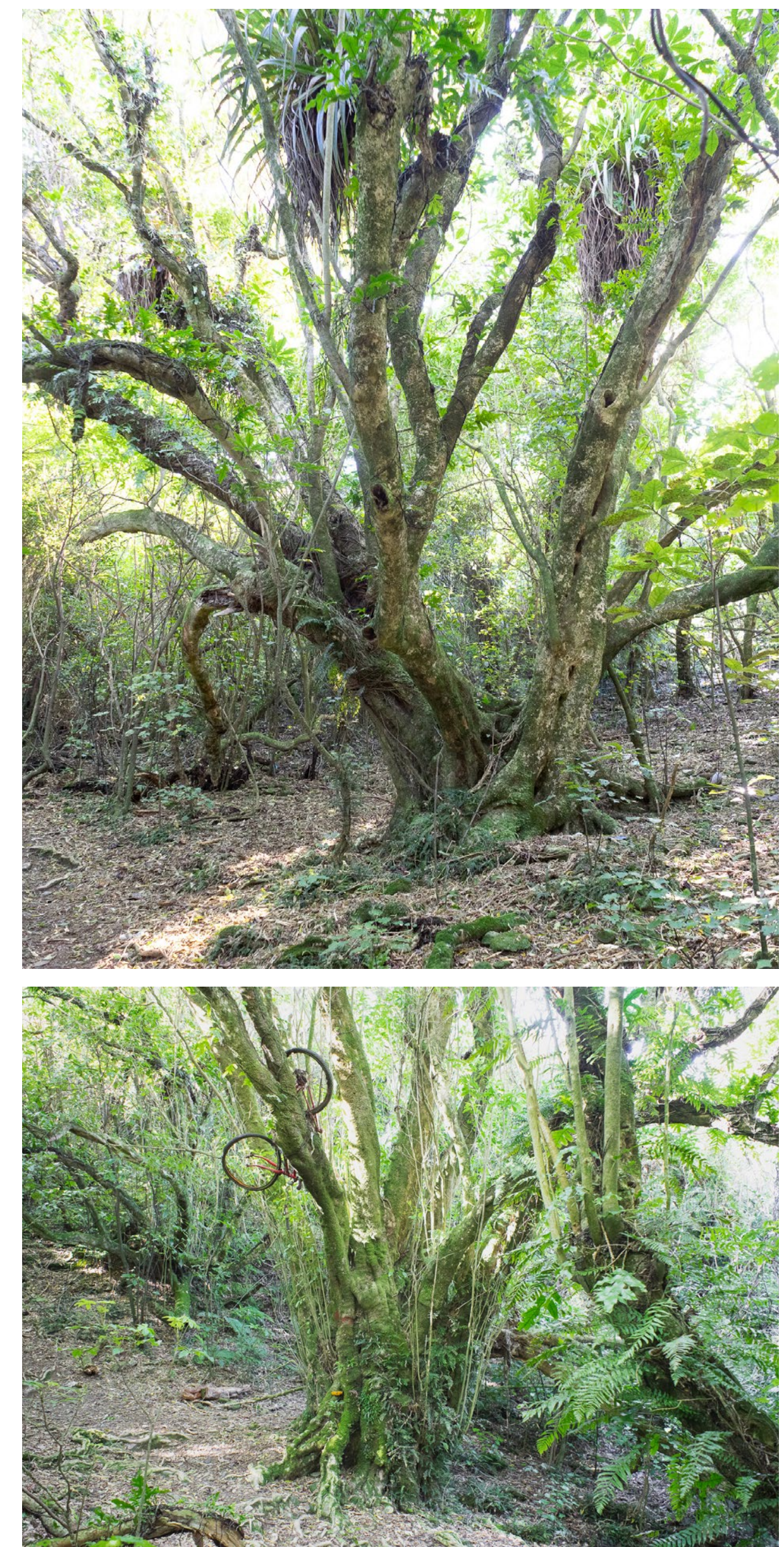

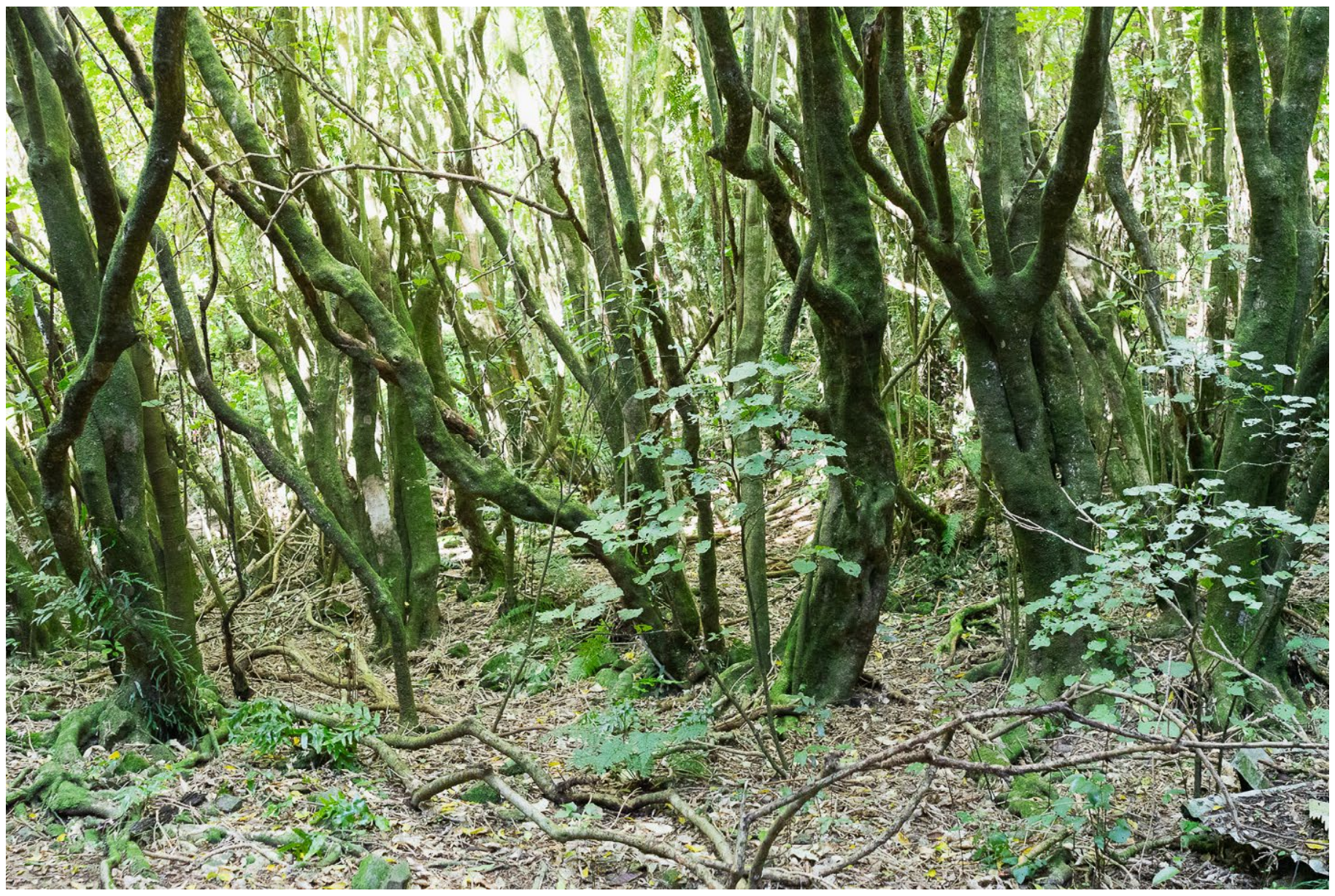

Transect

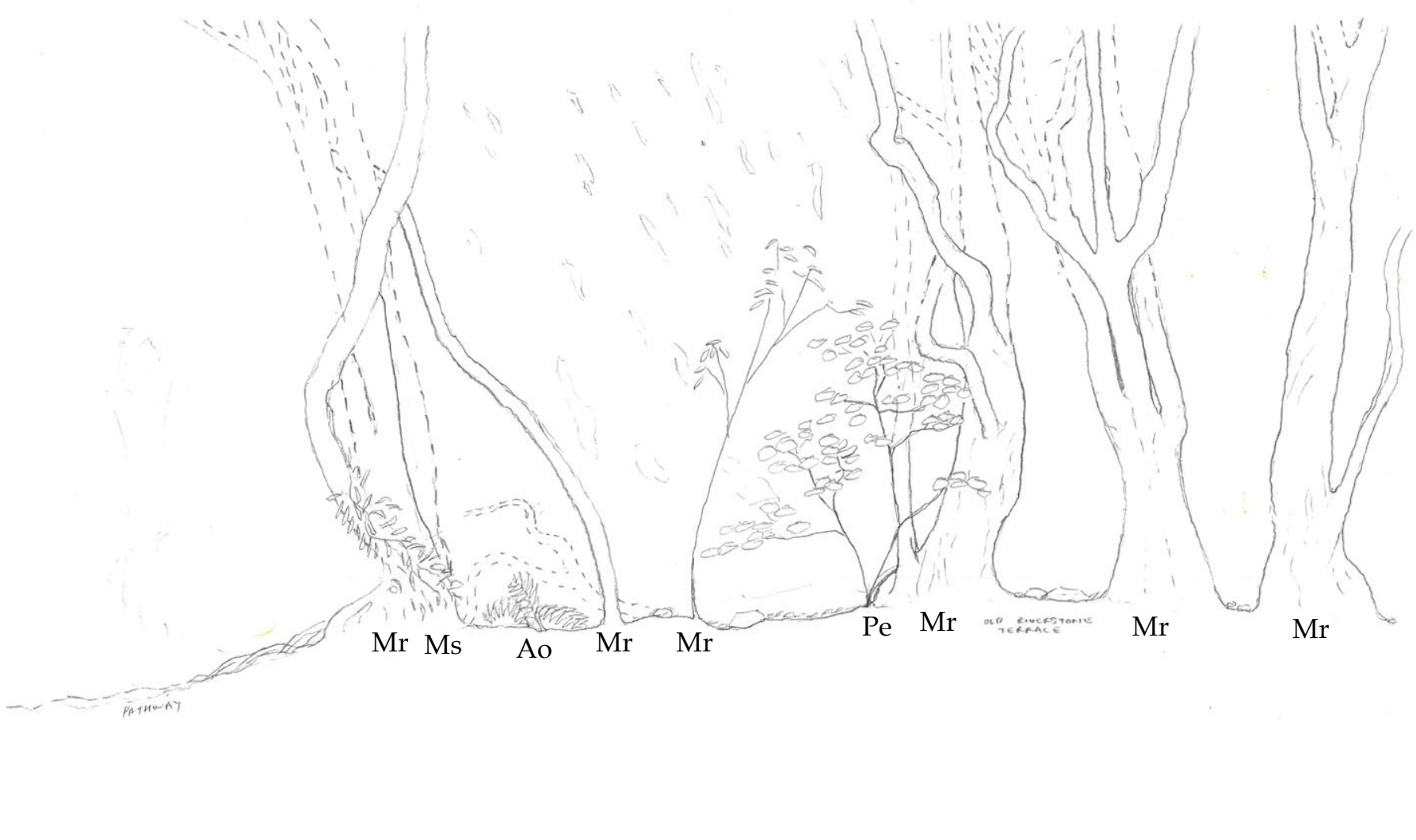


Otari's Kohekohe

Otari has some relatively well established kohekohe forest, with some ancient specimens. Kawakaw is the dominant sub-canopy plant and glows gren as sunlight filters down the small gullies.

Kawakawa brings a lightness to darker gullies that might otherwise spectacular in winter, when flowors emerge straight out of then flowers emerge straight out of their trunks. An important nectar source for tui flowers allows these markers for the deceased to interact with the for the of the present and future.

\section{Species present in transect}

$\mathrm{Ab}=$ Asplenium bulbiferum Hen and chicken fern $\mathrm{Gl}=$ Geniostoma ligustrifolium Hangehange

$\mathrm{Pe}=$ Piper excelsum

Kawakawa

Rs = Ripogonum scandens

Supplejack
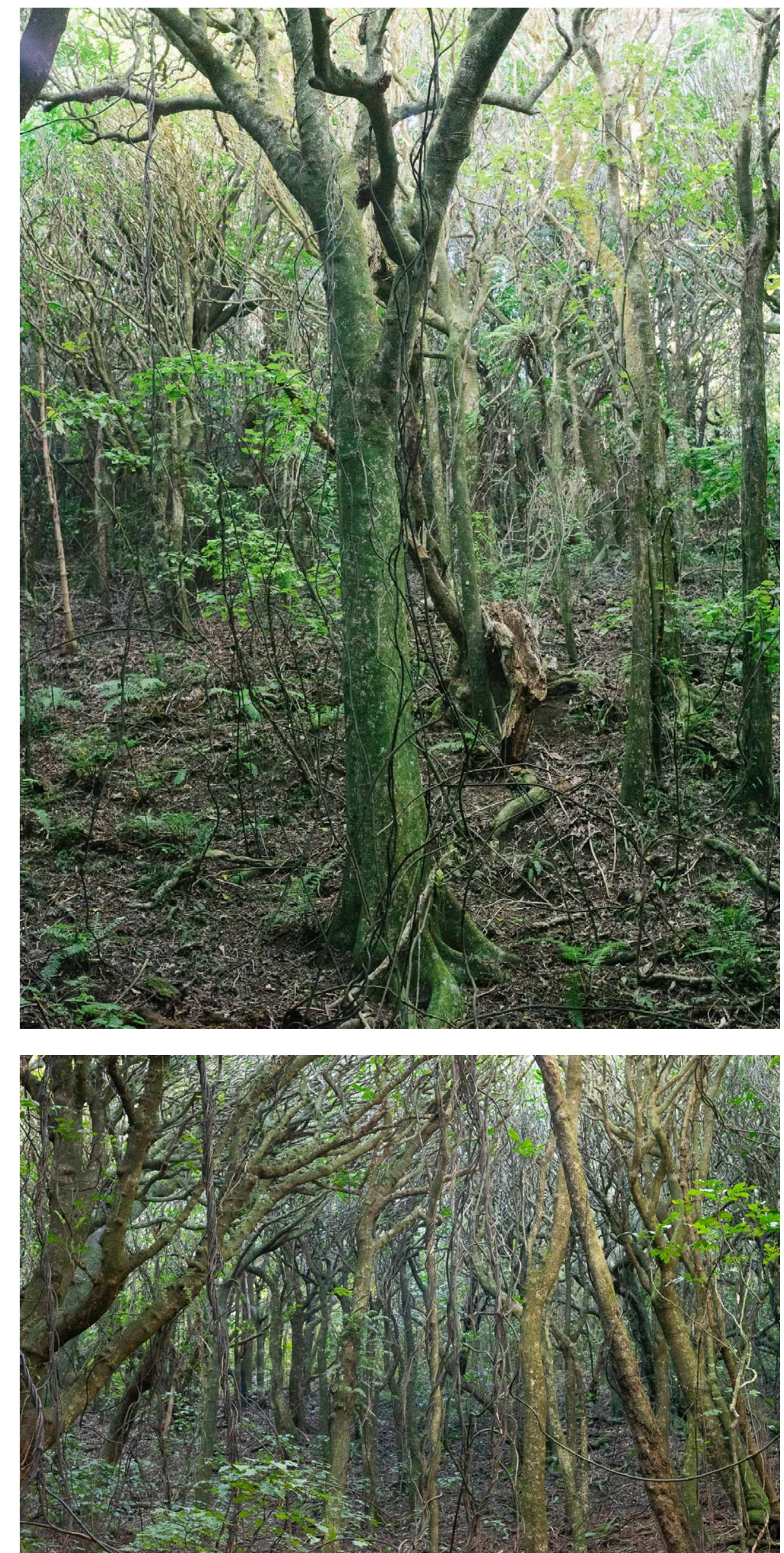
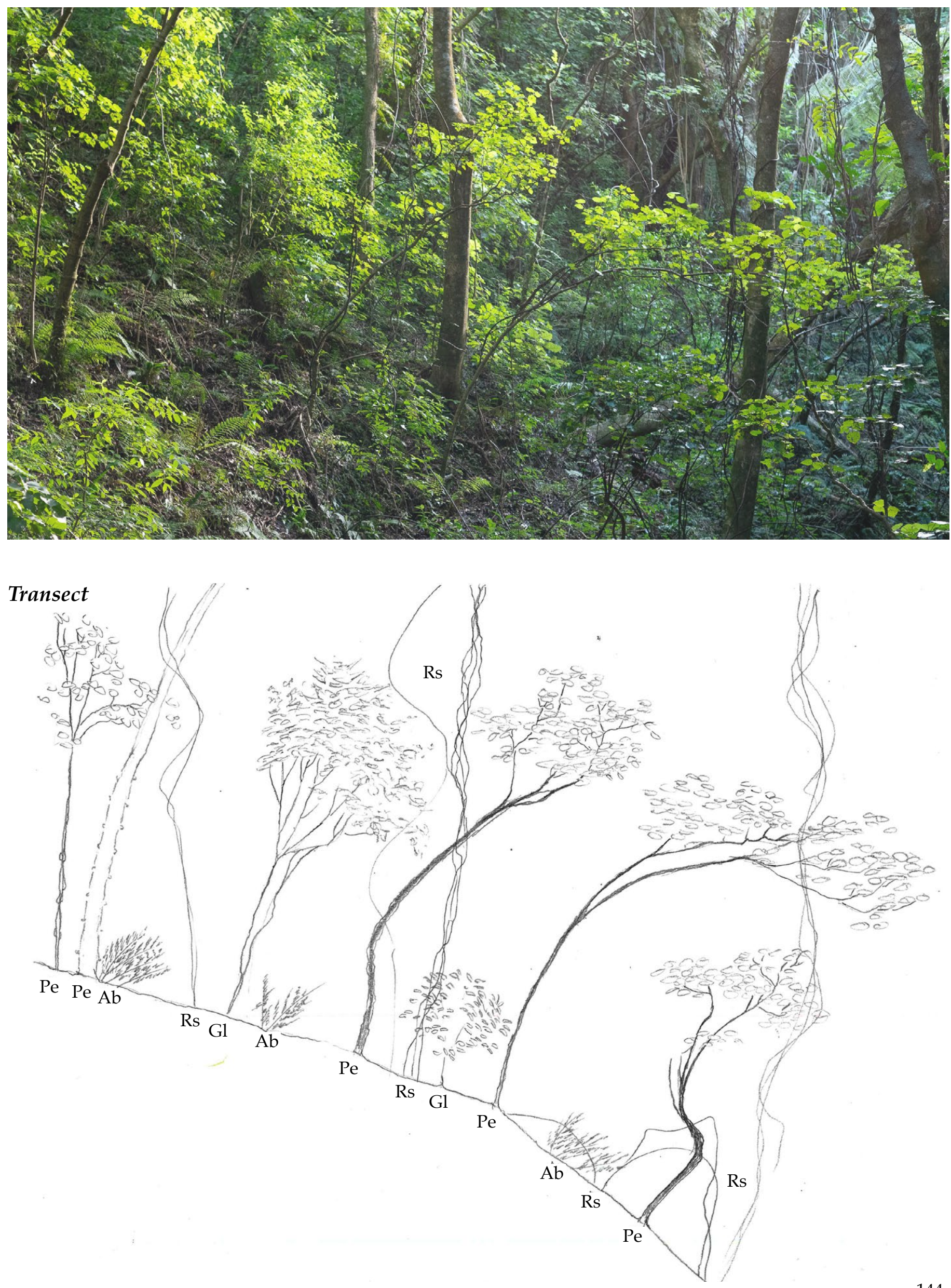
Huntleigh Park's Kohekohe and Supplejack

A wide south facing hillside carries on up to the outer town belt.

Supplejack creates a wiry landscape beneath the canopy.

Within kohekohe forest such as this, there would be potential to sustainably harvest supplejack canes. This vine has historically found use in basketry and is a sturdy materi The vines could be used to create caskets for the deceased (similar car in the retur

Species present in transect Ds = Dysoxylum spectabile Kohekohe $\mathrm{Gl}=$ Geniostoma ligustrifolium Hangehange

Rs = Ripogonum scandens Supplejack
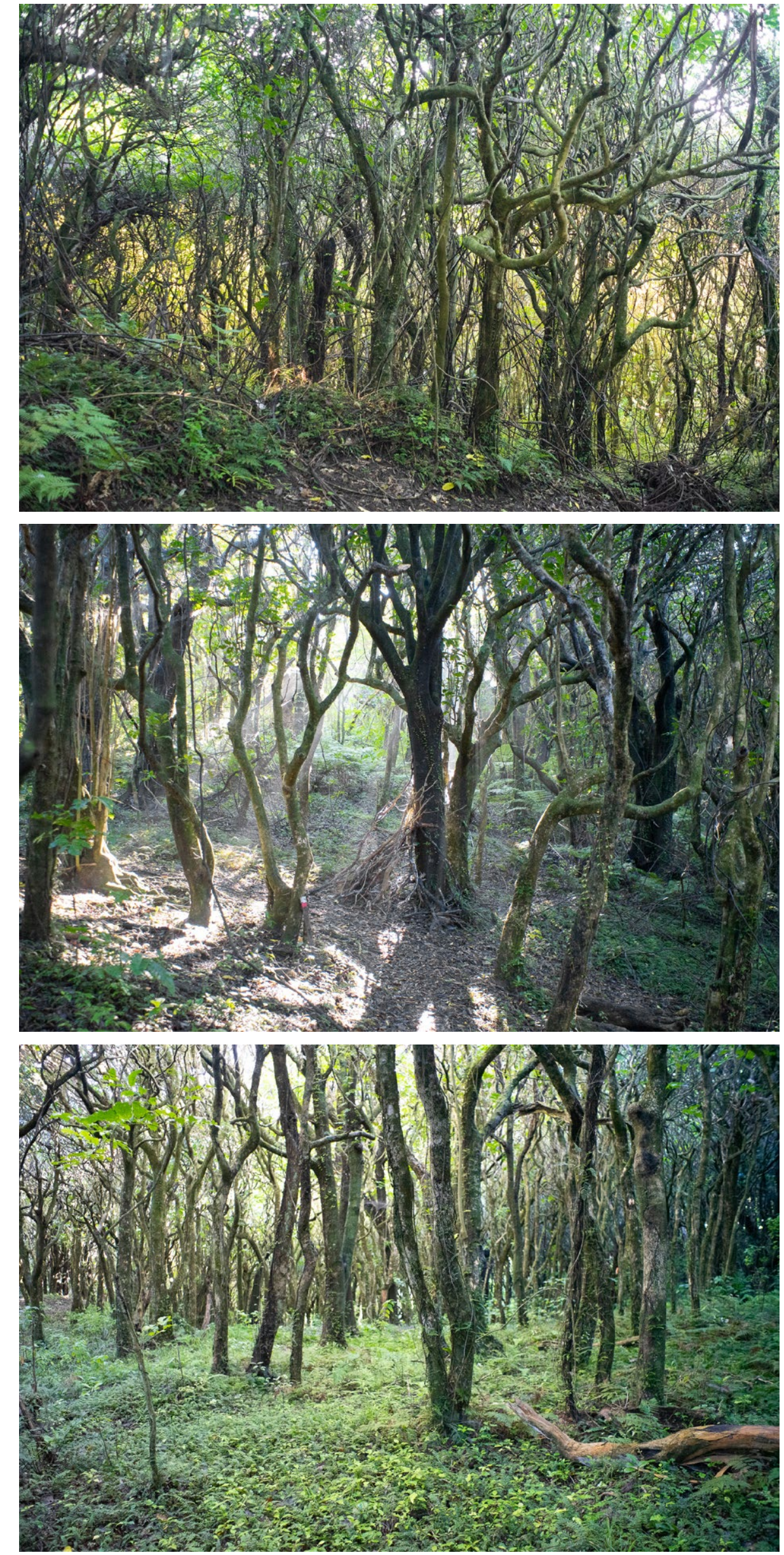

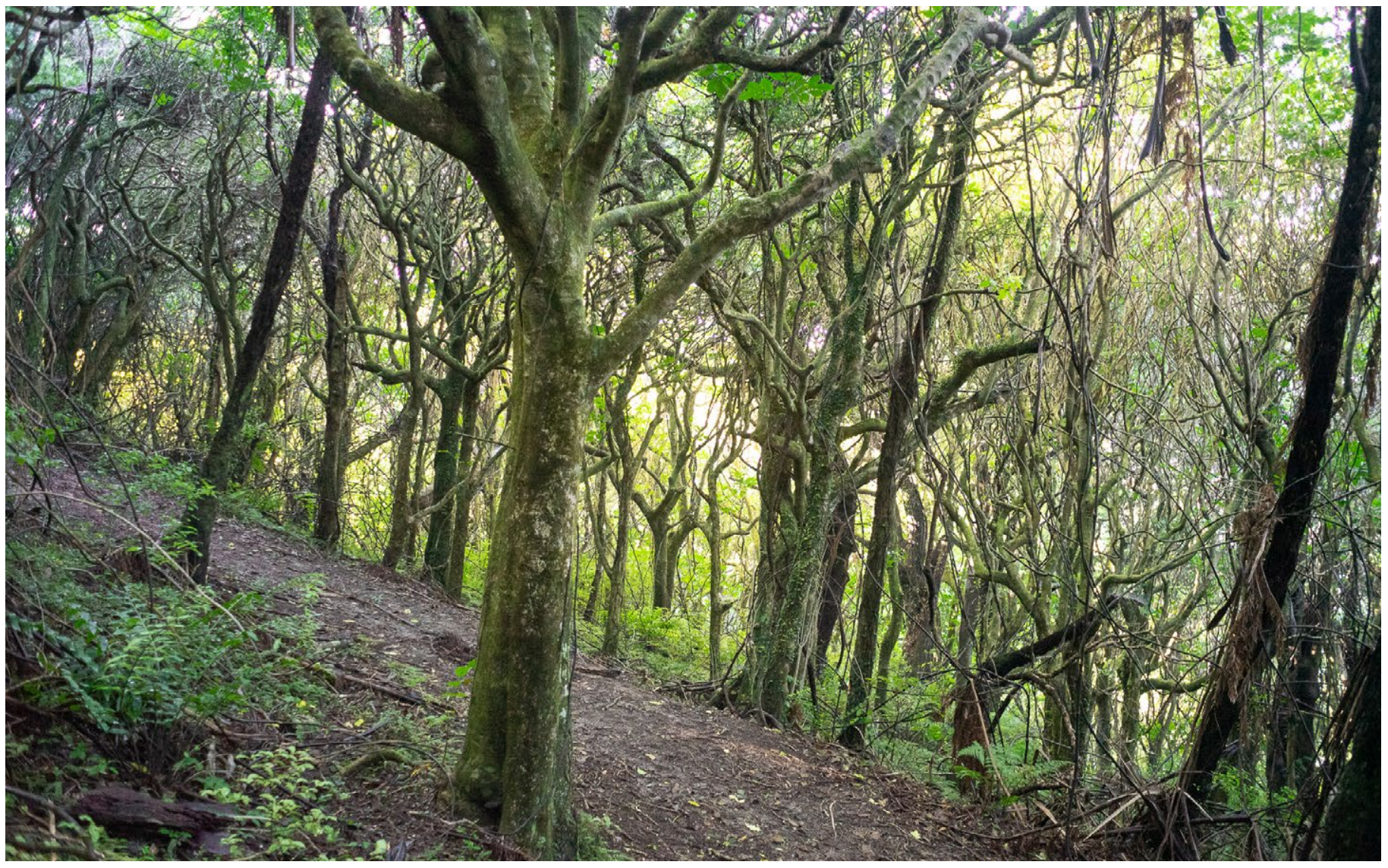

Transect

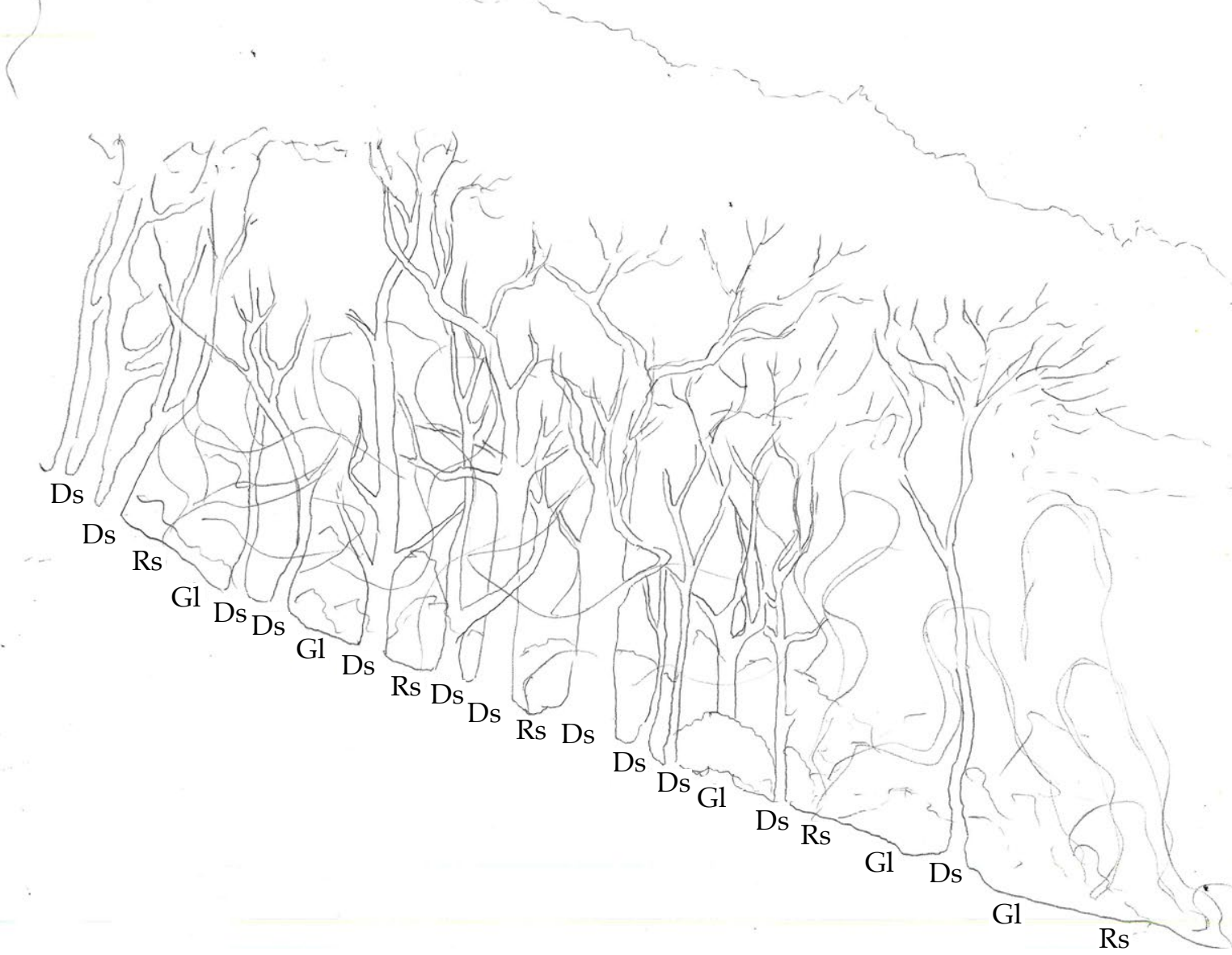


Paekakariki Escarpment Kohekohe and Kawakawa

Areas of scree slopes on the

Paekakariki escarpment share

similar characteristics to those on T Ahumairangi.

Of particular interest, is the way in which scree that continues to roll downhill, accumulates at the base of vegetation blocking its path. Forming small cairns, similar to stone mounds resting places for millennia.

With burial in scree on Te

Ahumairangi, the burial process

would naturally form small mounds

wom soil, these with time.

Species present in transect

$\mathrm{Pe}=$ Piper excelsum

Kawakawa

147.
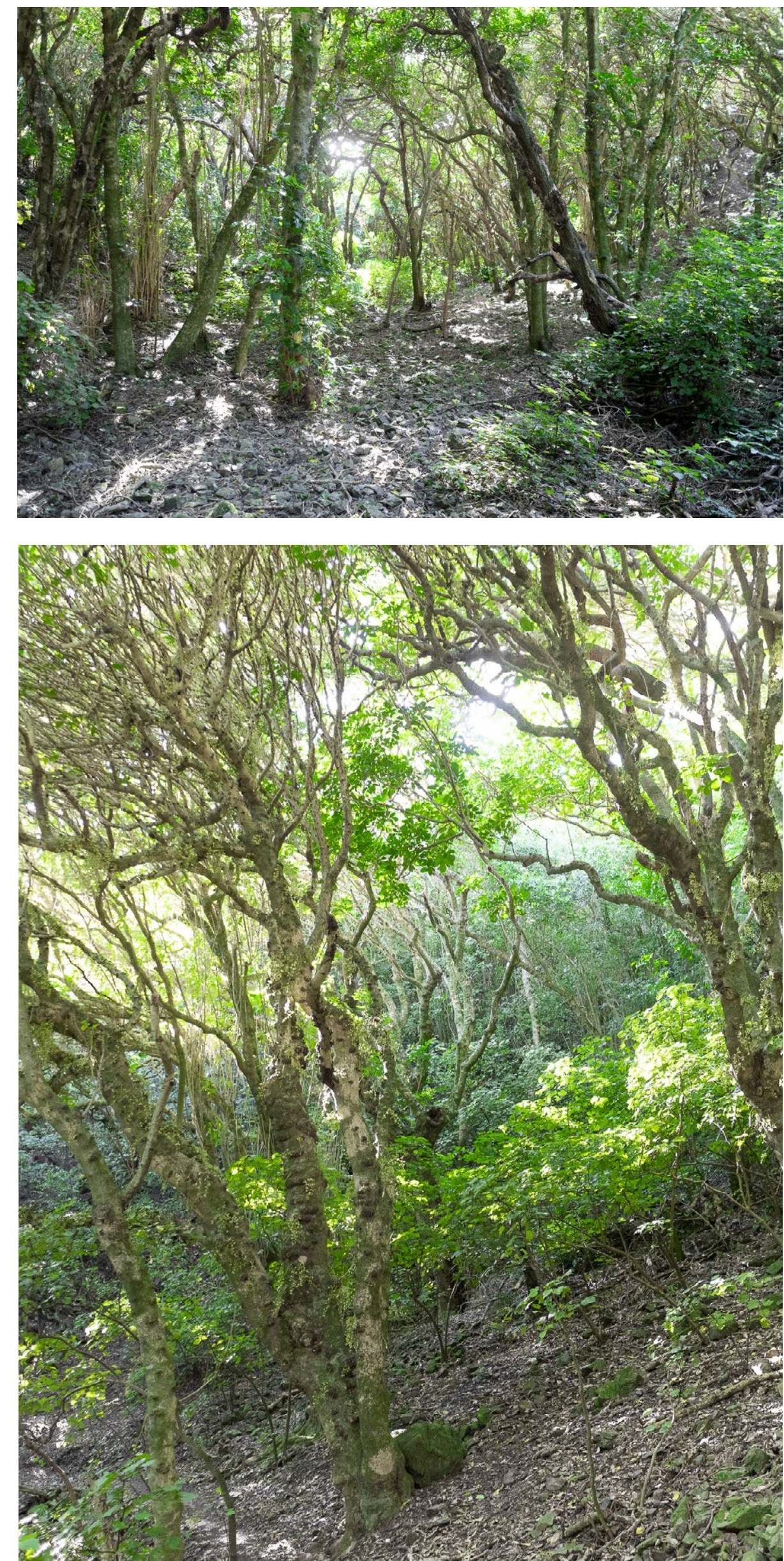
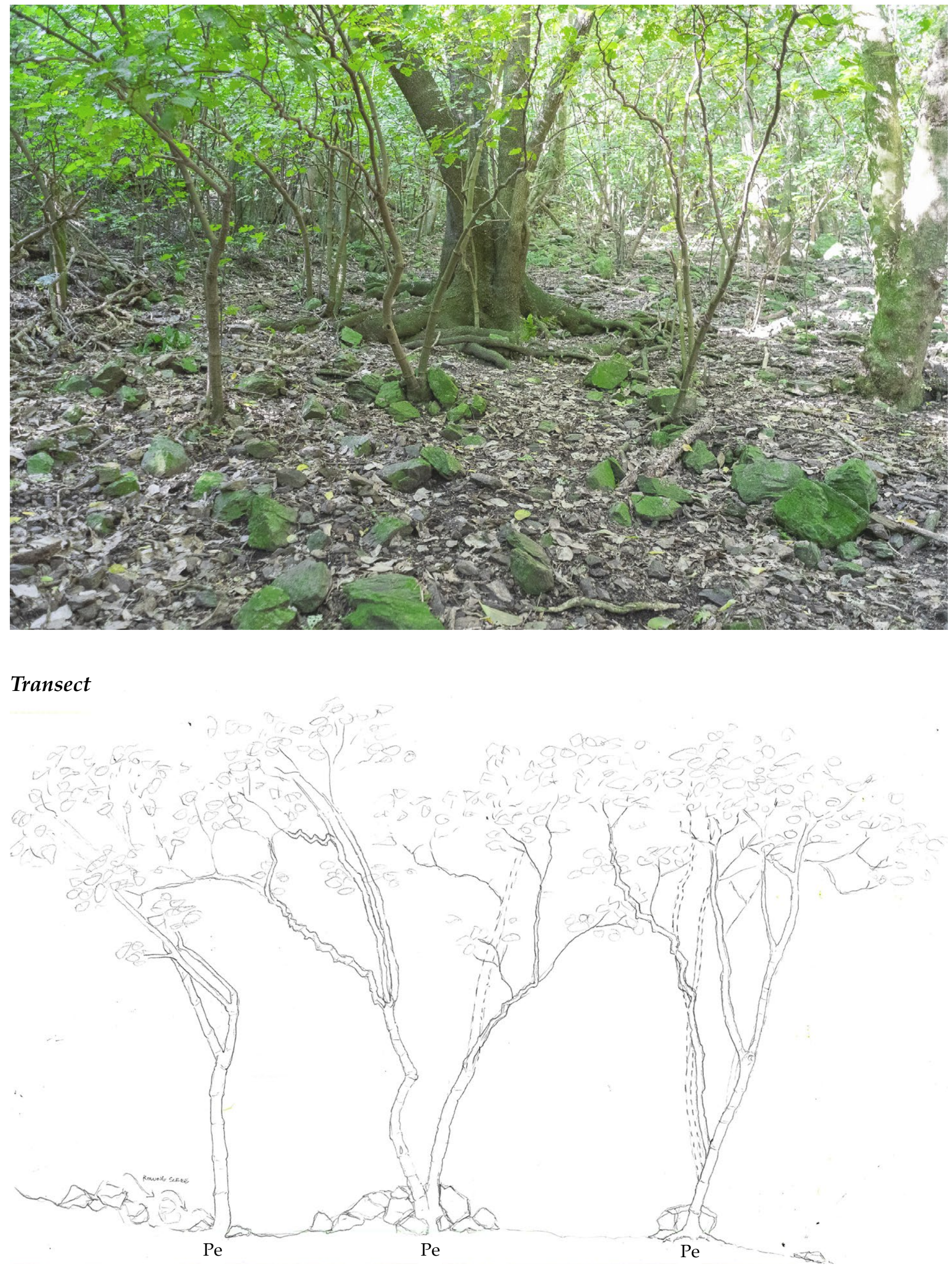
Mount Kaukau

The gullies of Mt Kaukau are lush and damp. Pukatea are large valley trees with heavily buttressed roots that give them stability in wet ground.

These trees hold large amounts of water. As aquamation (bodily trees would be capable of uptaking liquified remains. In this way liquified remains. In this way, the essence of a person becomes Similar to the way the cremated ash may be on the breeze remain are amongst aquama
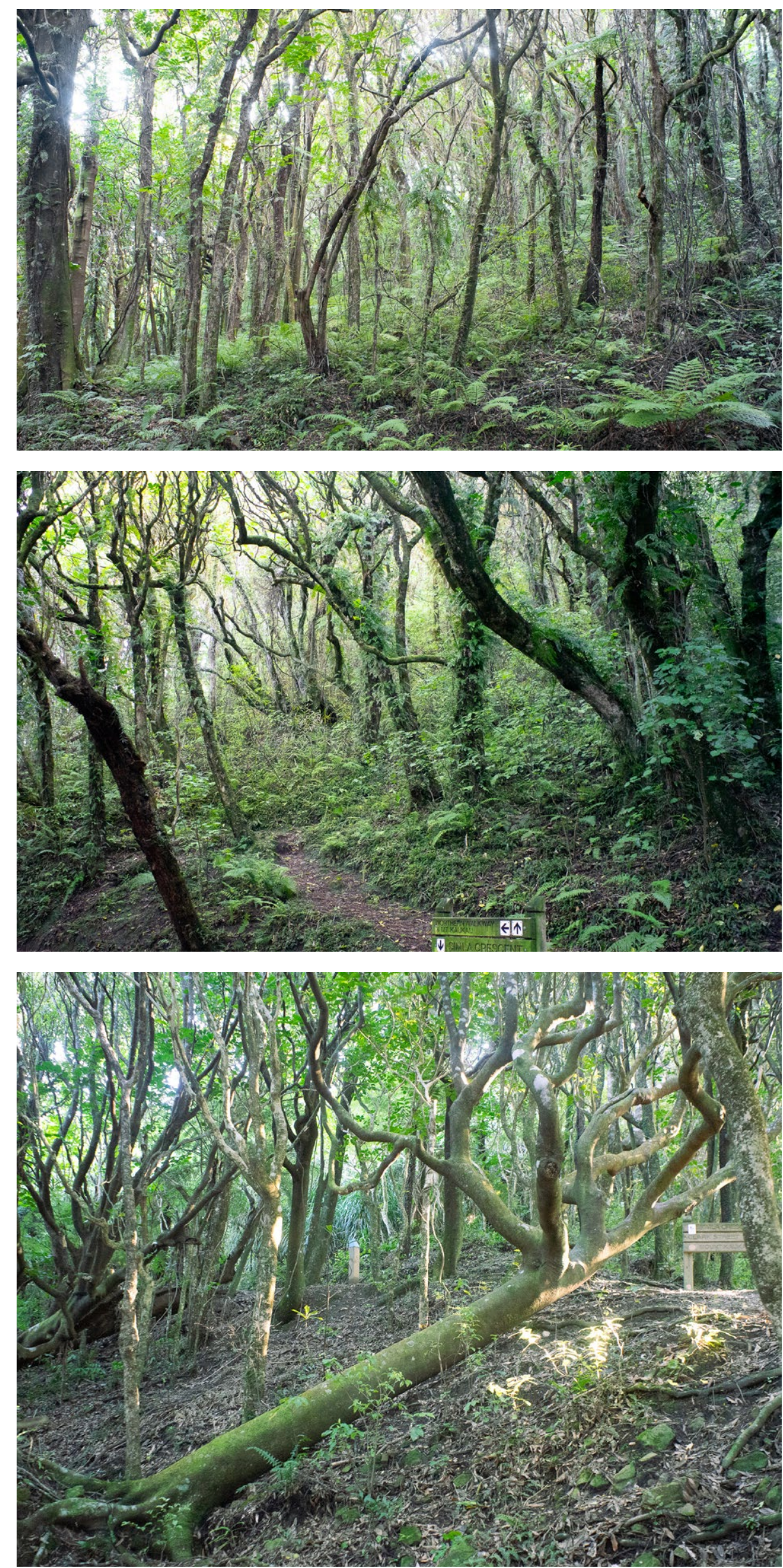

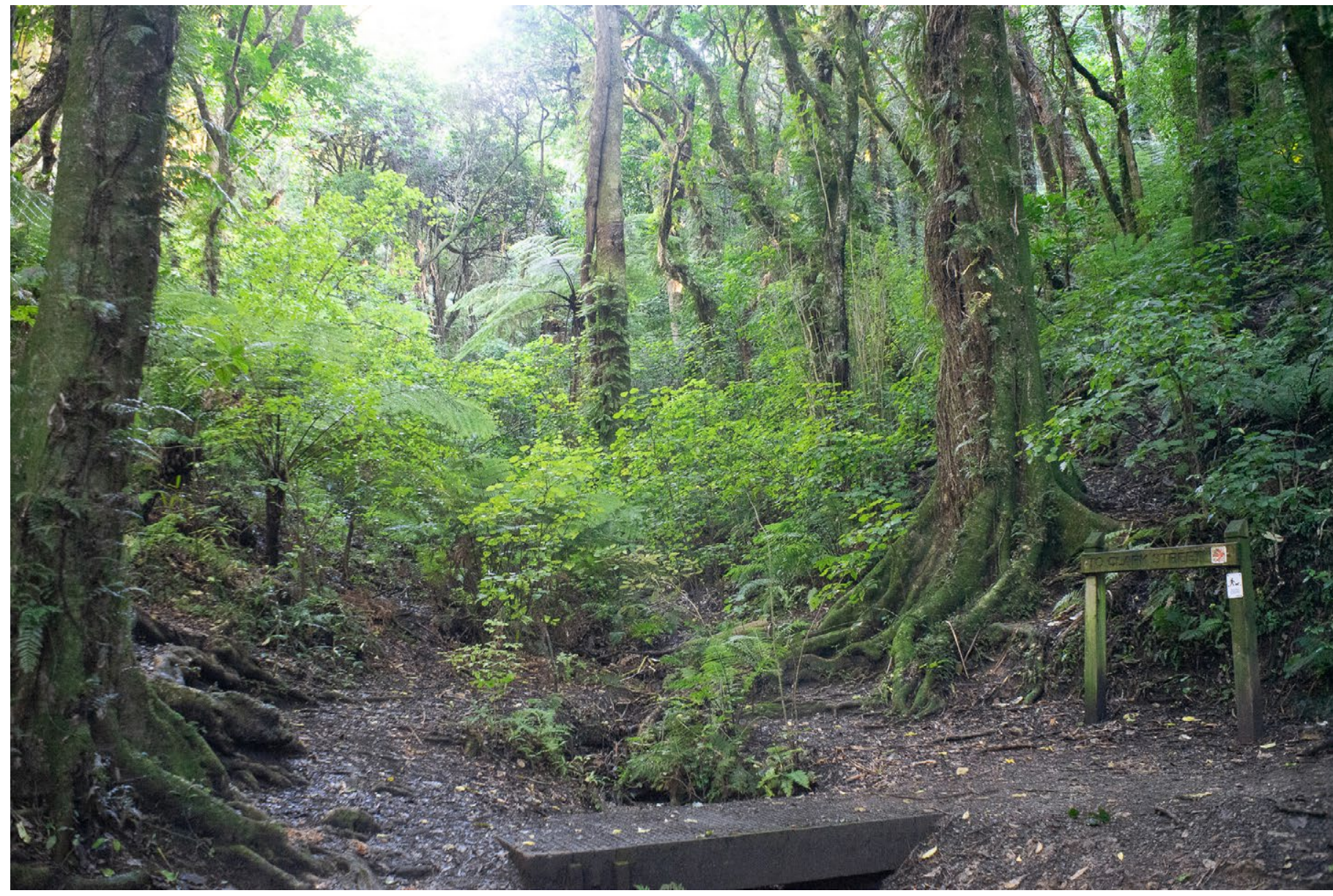

Transect

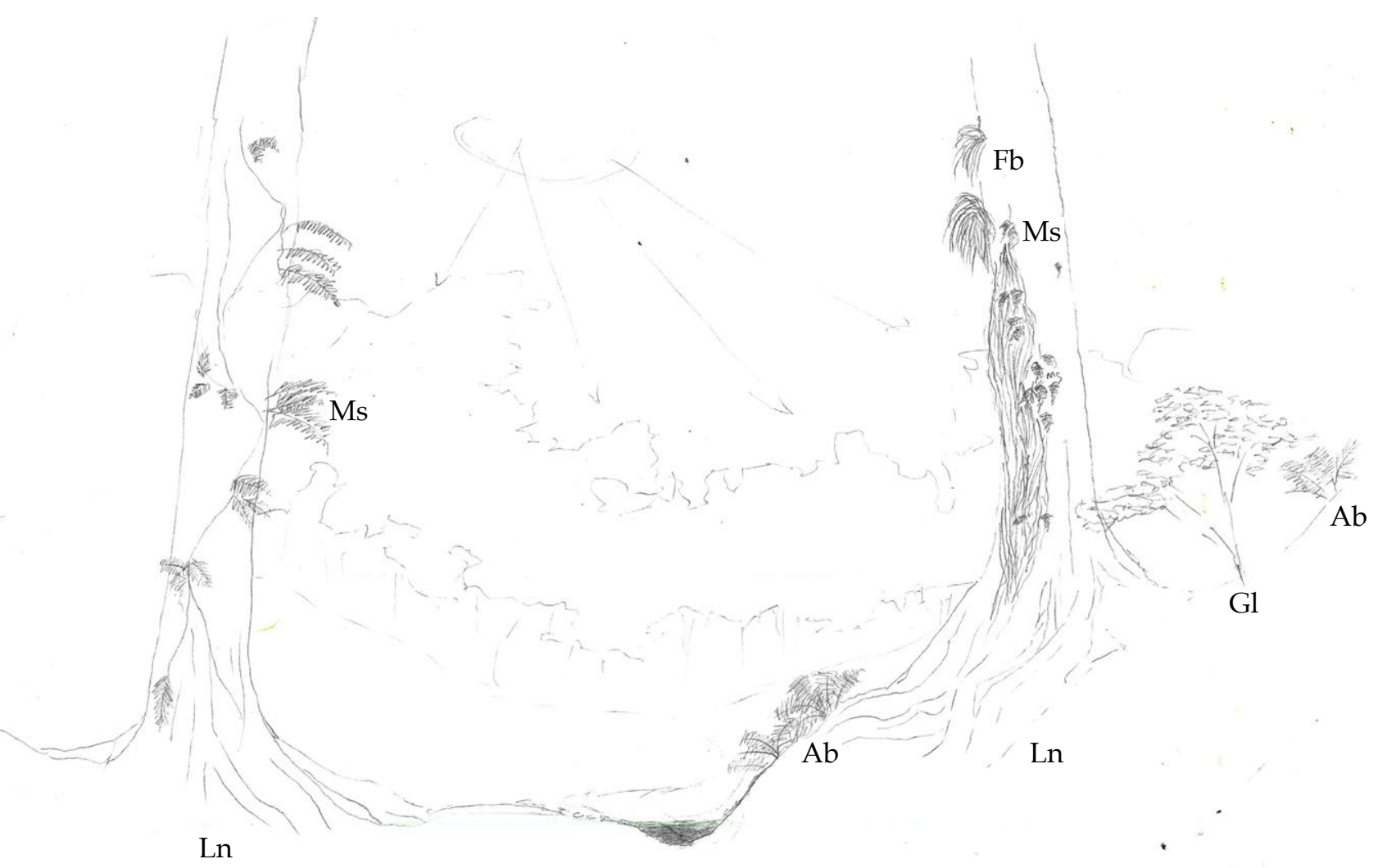




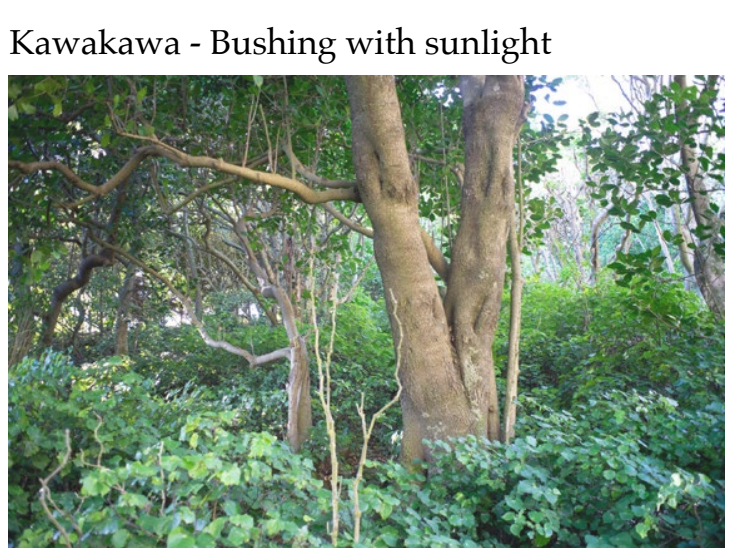

Kawakawa - Reaching to sunlight

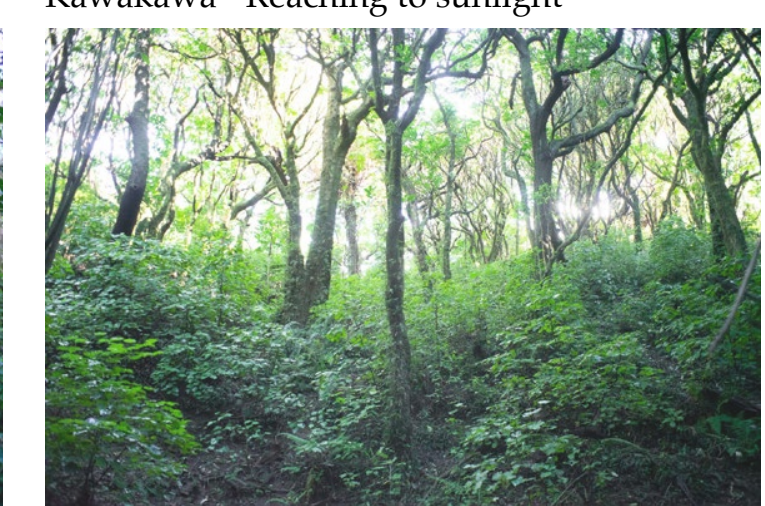

Blechnum - Near vertical

Hen and Chicken + Karetu - In clearing

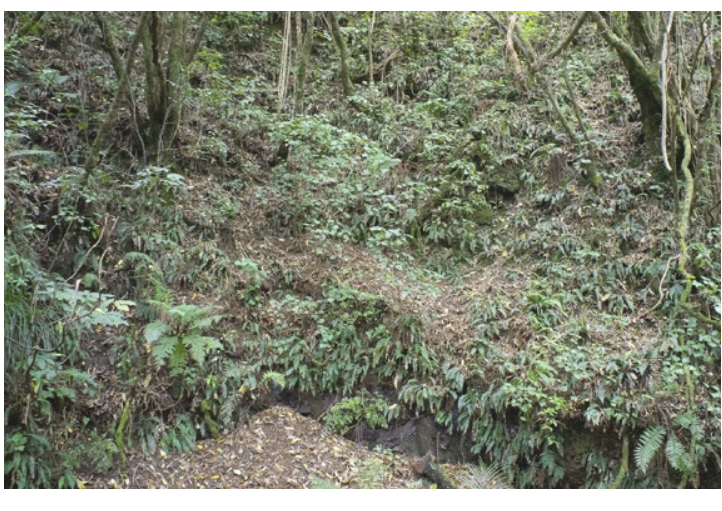

Native Passionfruit -Thick in old forest

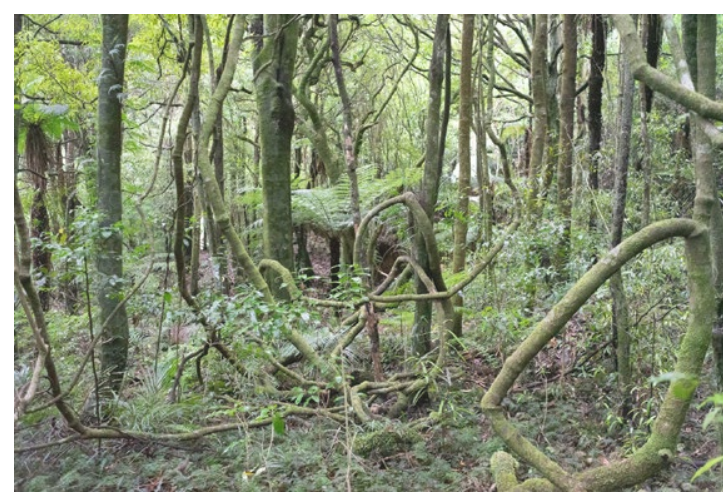

Blechnum fluviatile - In kohekohe forest

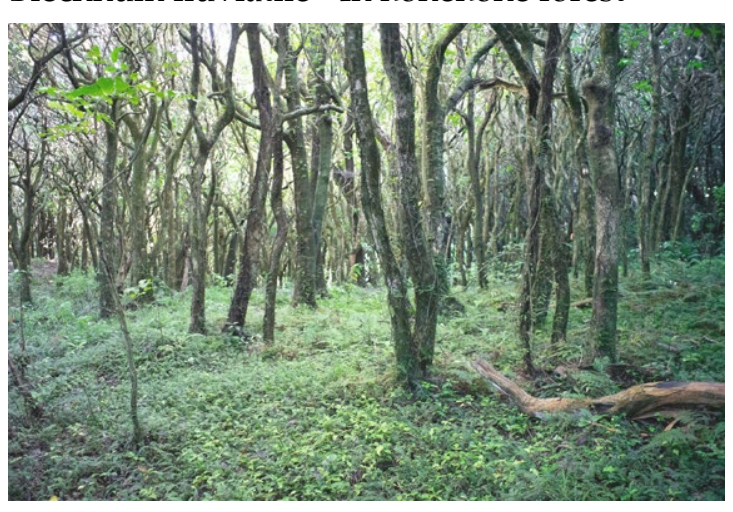

Blechnum fluviatile - In kohekohe forest

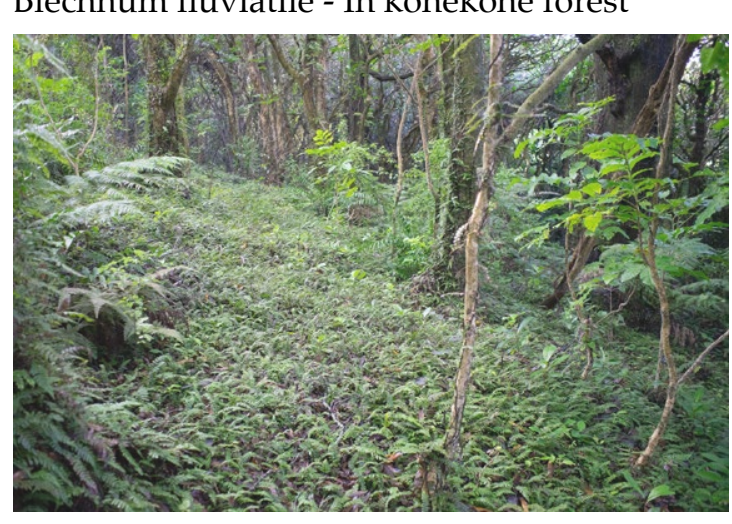

Kawakawa - Inadequate sunlight

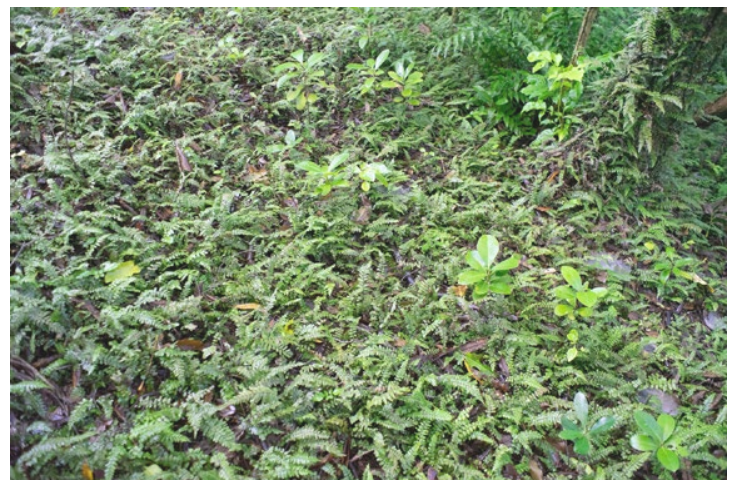

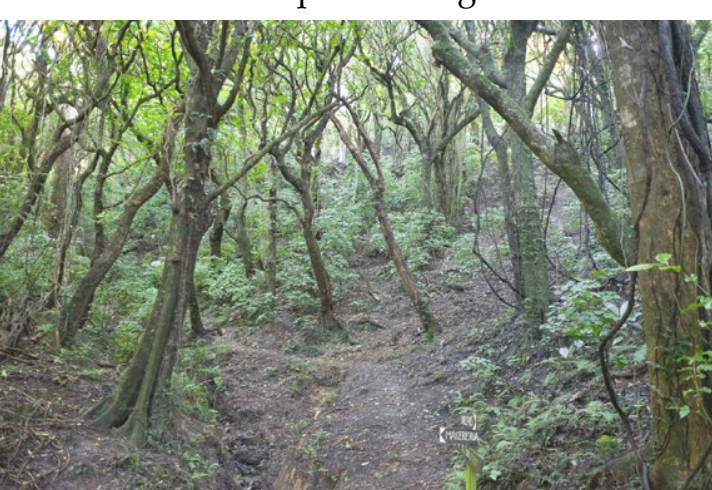

Kiokio - Higher altitude

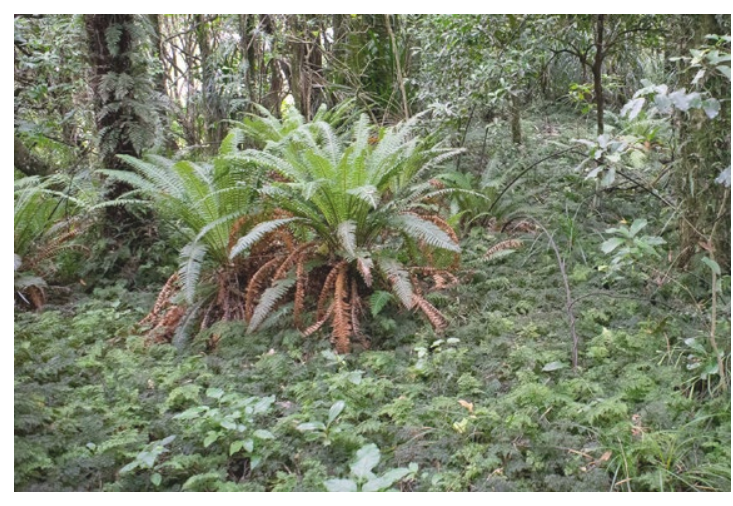

Blechnum filiforme - Scrambling over scree

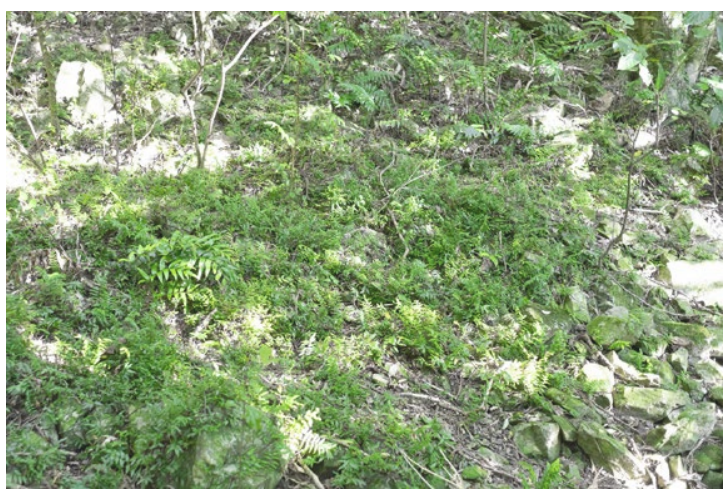

Blechnum fluviatile - w/ karaka seedlings

Supplejack- Scrambling

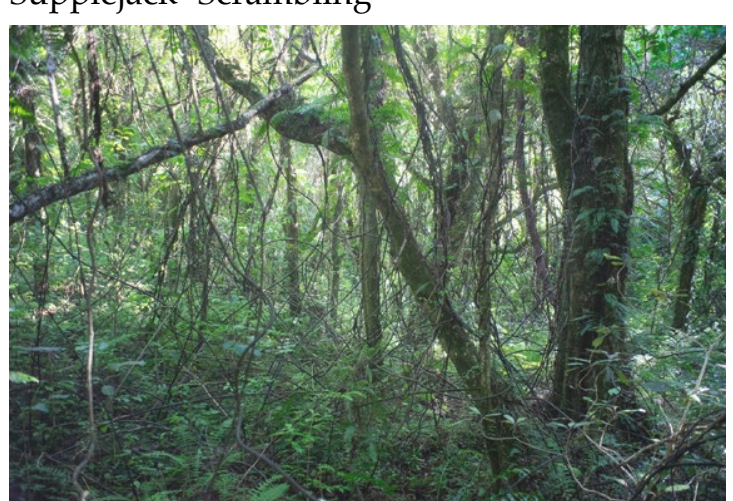

Hen and Chicken - In kohekohe thicket

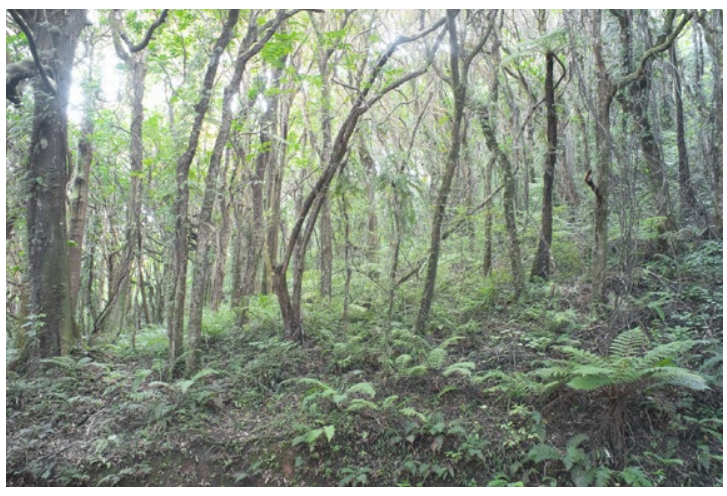

Fragrant Fern - Scrambling over stones

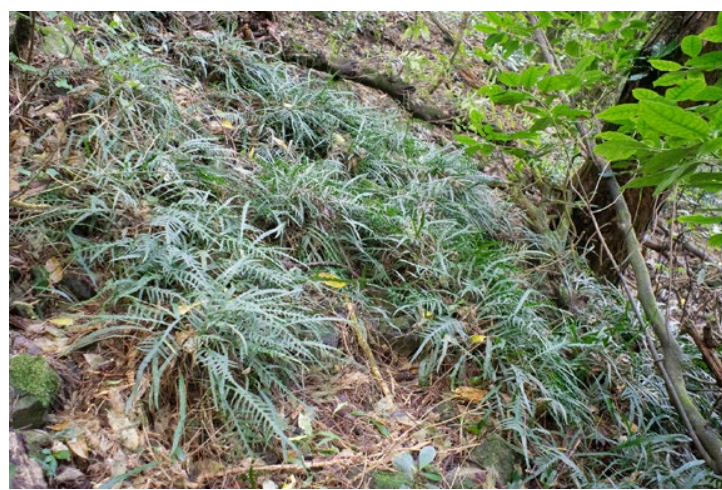

Hounds tongue fern - Under pine 


\section{Ridgelines}

1. Alectryon excelsus
Titoki
2. Beilschmiedia tawa
Tawa
3. Dacrydium cupressinum
Rimu
4. Eleaocarpus dentatus
Hinau
5. Fuscospora truncata
Hard Beech
6. Knightia excelsa
Rewarewa
7. Lophomyrtus bullata
Ramarama
8. Metrosideros robusta
Northern Rata
9. Nestegis cunninghamii
Black Maire
10. Pennantia corymbosa
Kaikomako
11. Pittosporum eugenoides
Lemonwood
12. Prumnopitys taxifolia
Matai
13. Pseudopanax arboreus
Five-finger
14. Raukaua edgerleyi
Raukawa
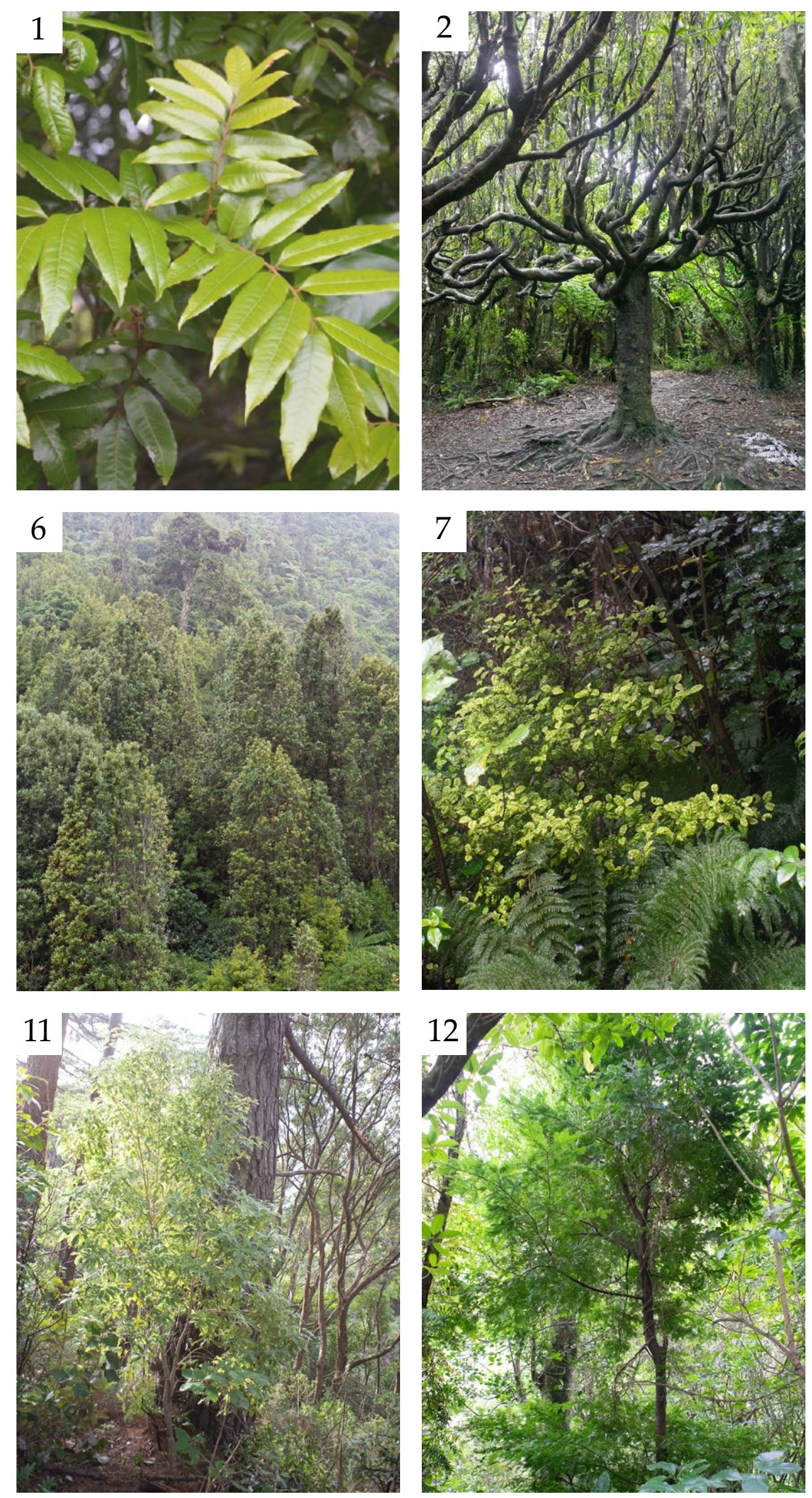
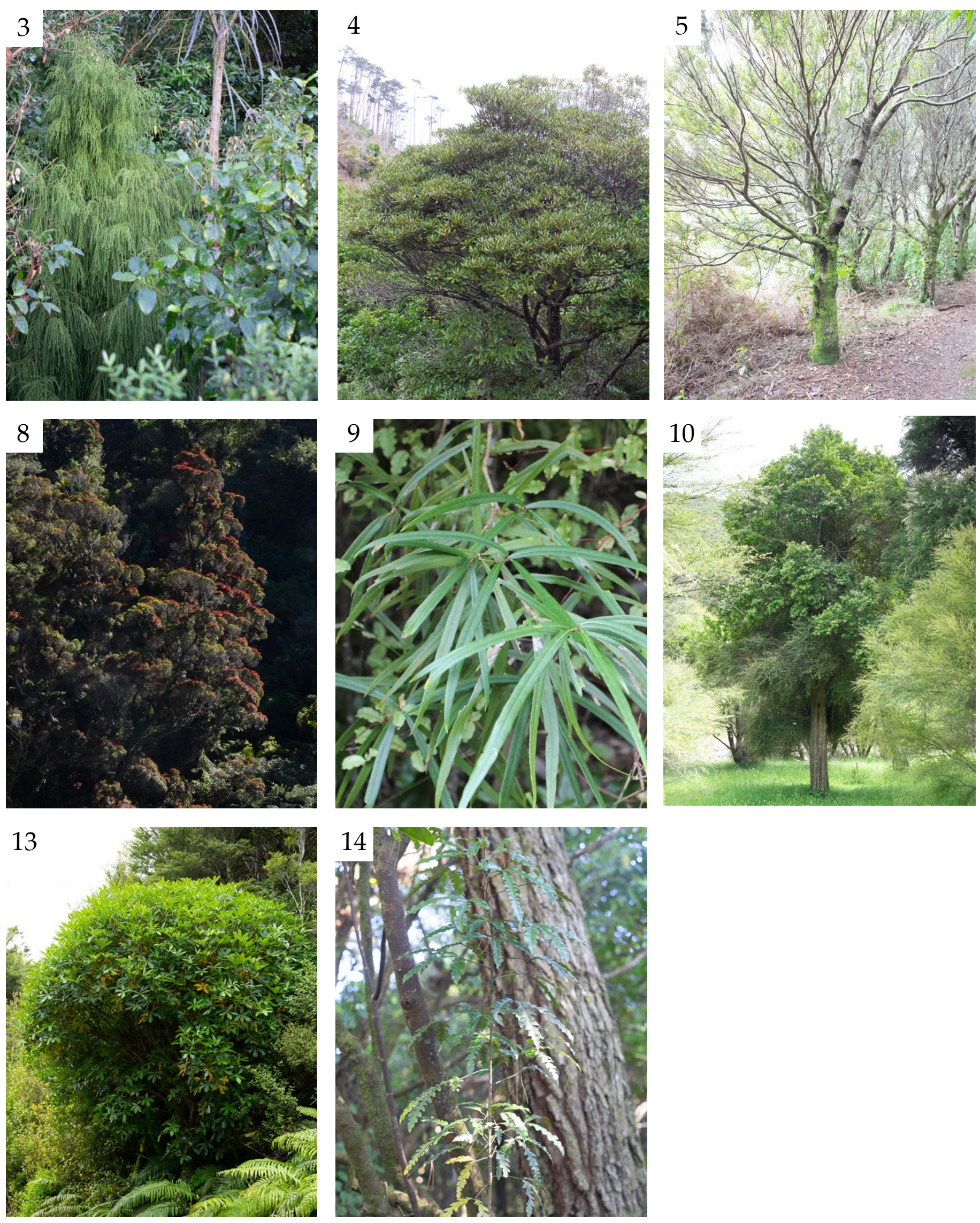


\section{Valleys}

1. Cyathea medullaris

Mamaku

2. Dacrycarpus dacrydioides Kahikatea

3. Dysoxylum spectabile Kohekohe

4. Freycinetia banksii Kiekie

5. Fuschia excorticata Kotukutuku

6. Laurelia novae-zelandiae Pukatea

7. Melicope ternata Wharangi

8. Melicytus ramiflorus Mahoe

9. Piper excelsum Kawakawa

10. Podocarpus totara Totara

11. Rhopalostylis sapida Nikau

12. Ripogonum scandens Supplejack

13. Schefflera digitata Pate
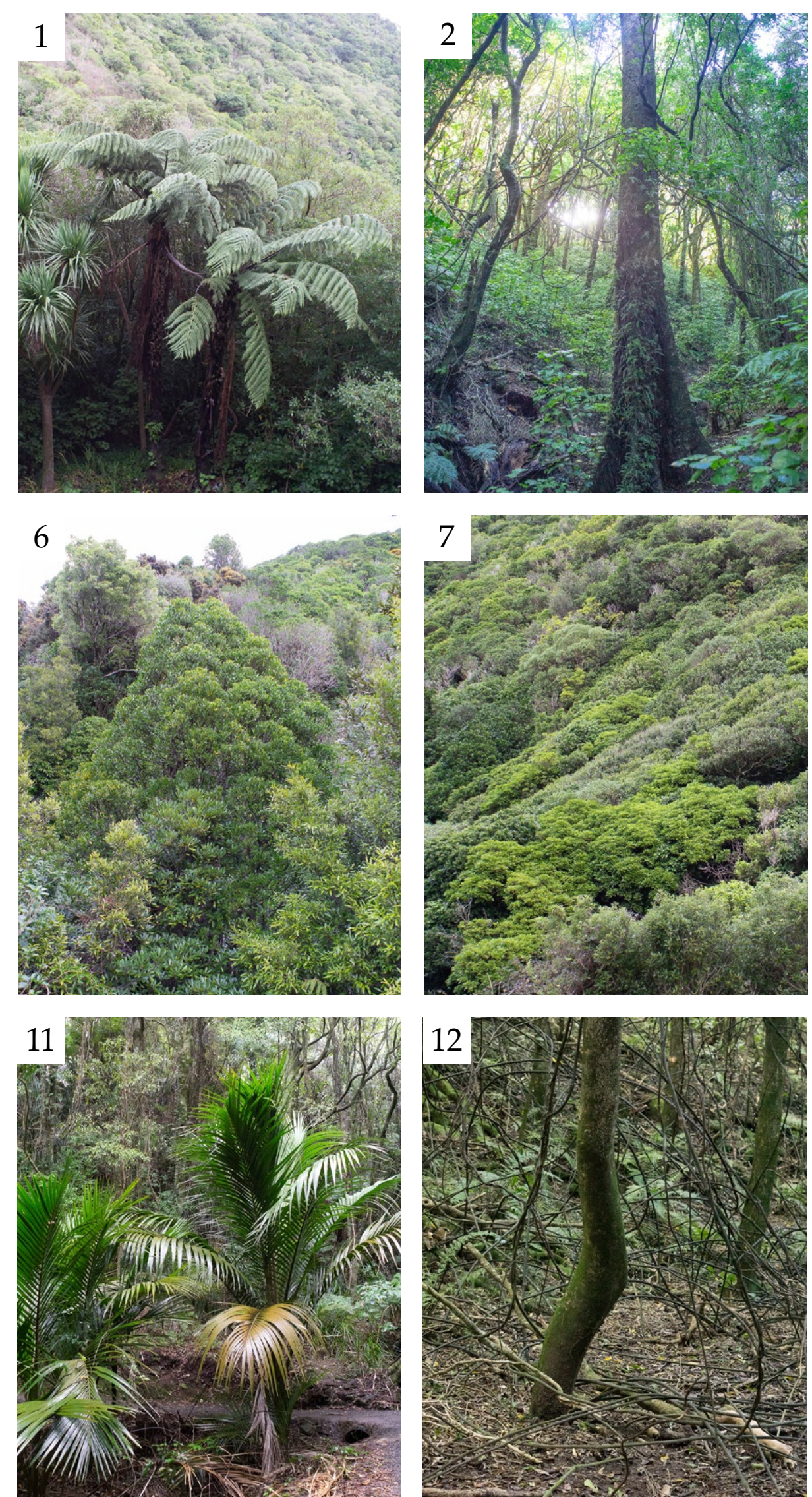
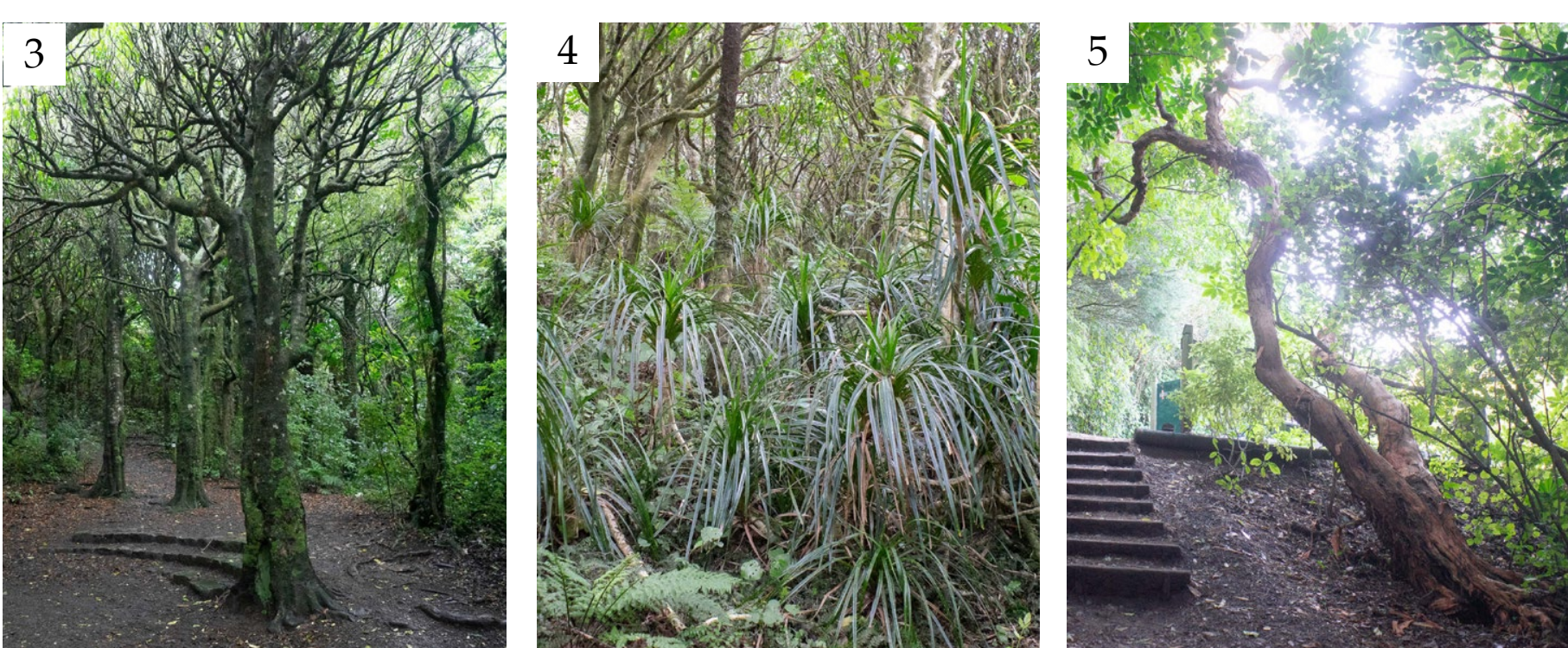

8 if 1 M
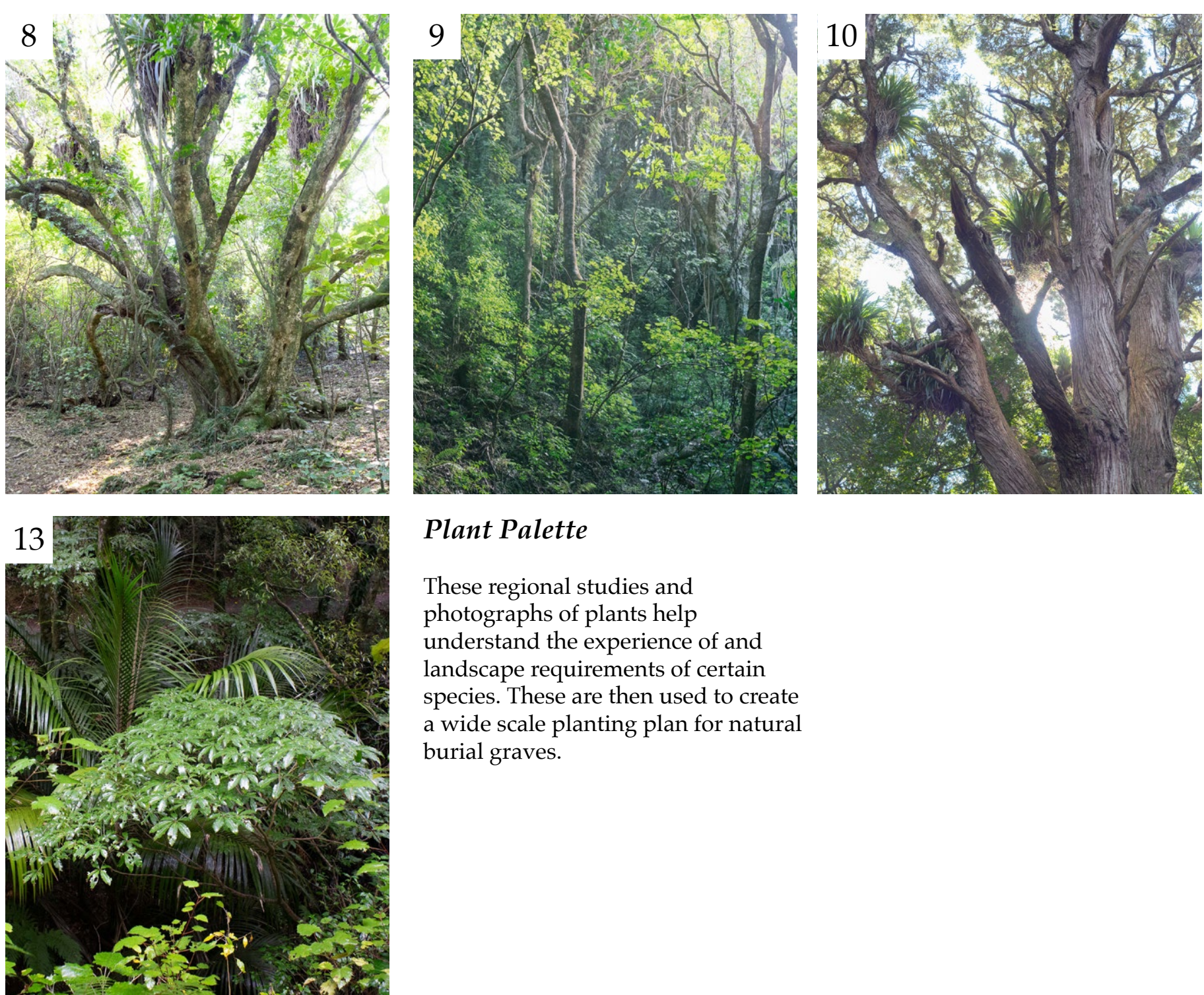

\section{Plant Palette}

These regional studies and

photographs of plants help

understand the experience of and

landscape requirements of certain

a wide scale planting plan for natural

burial graves. species. These are then used to create 


\section{Chapter Six}

\section{Design \\ Investigation}




\section{Forests of Death}

\section{DESIGN PHASE 1}

Sets up the logic for the development of a site masterplan. This diagram explains the key ideas explored in this phase of design development and how they tie into the initial research.

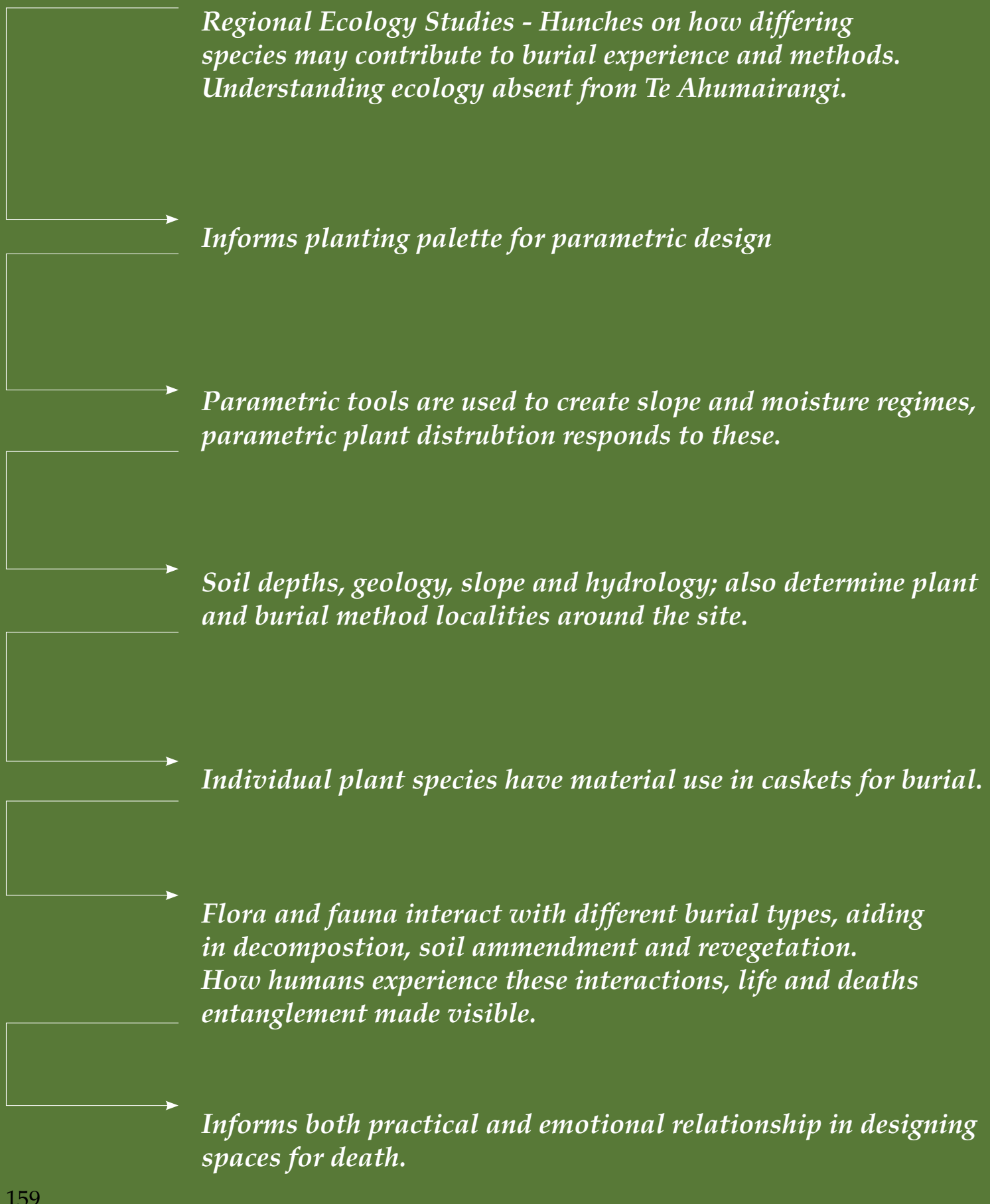


PARAMETRIC PLANTING

List of Species

Species Name

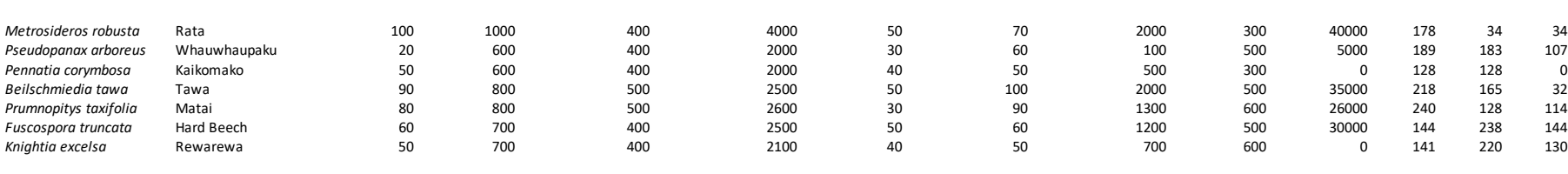

$$
\begin{aligned}
& \text { MODERATELY DRY }
\end{aligned}
$$

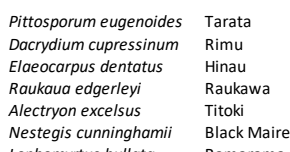

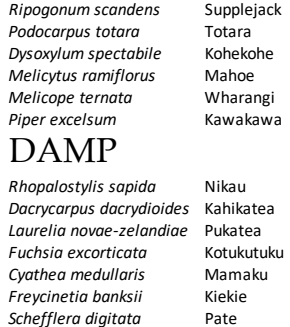

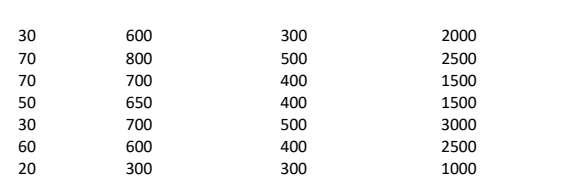

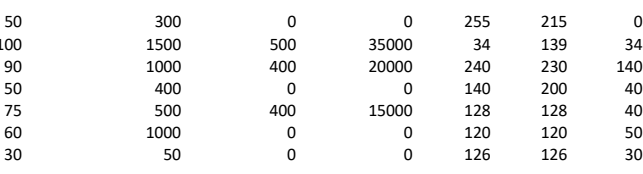

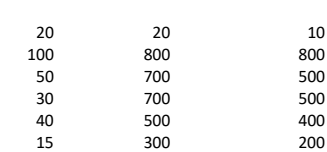

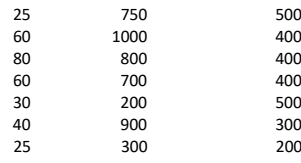

$$
\begin{aligned}
& \begin{array}{r}
200 \\
4000 \\
2000 \\
2000 \\
2000 \\
1500
\end{array}
\end{aligned}
$$

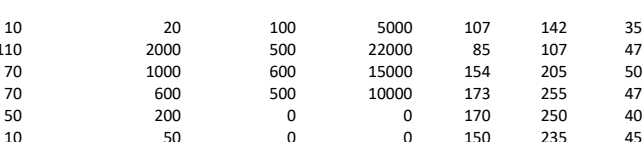

$$
\begin{aligned}
& \begin{array}{l}
3000 \\
3000 \\
2500 \\
2400 \\
3000 \\
1000 \\
1500
\end{array}
\end{aligned}
$$

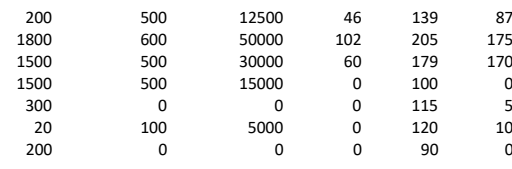

These species are chosen from the regional ecologies field work. Their relative absence from Te Ahumairangi and potential in creating experience are drivers for their selection.

\section{PARAMETRIC PLANTING}

Grasshopper - Groundhog Definition

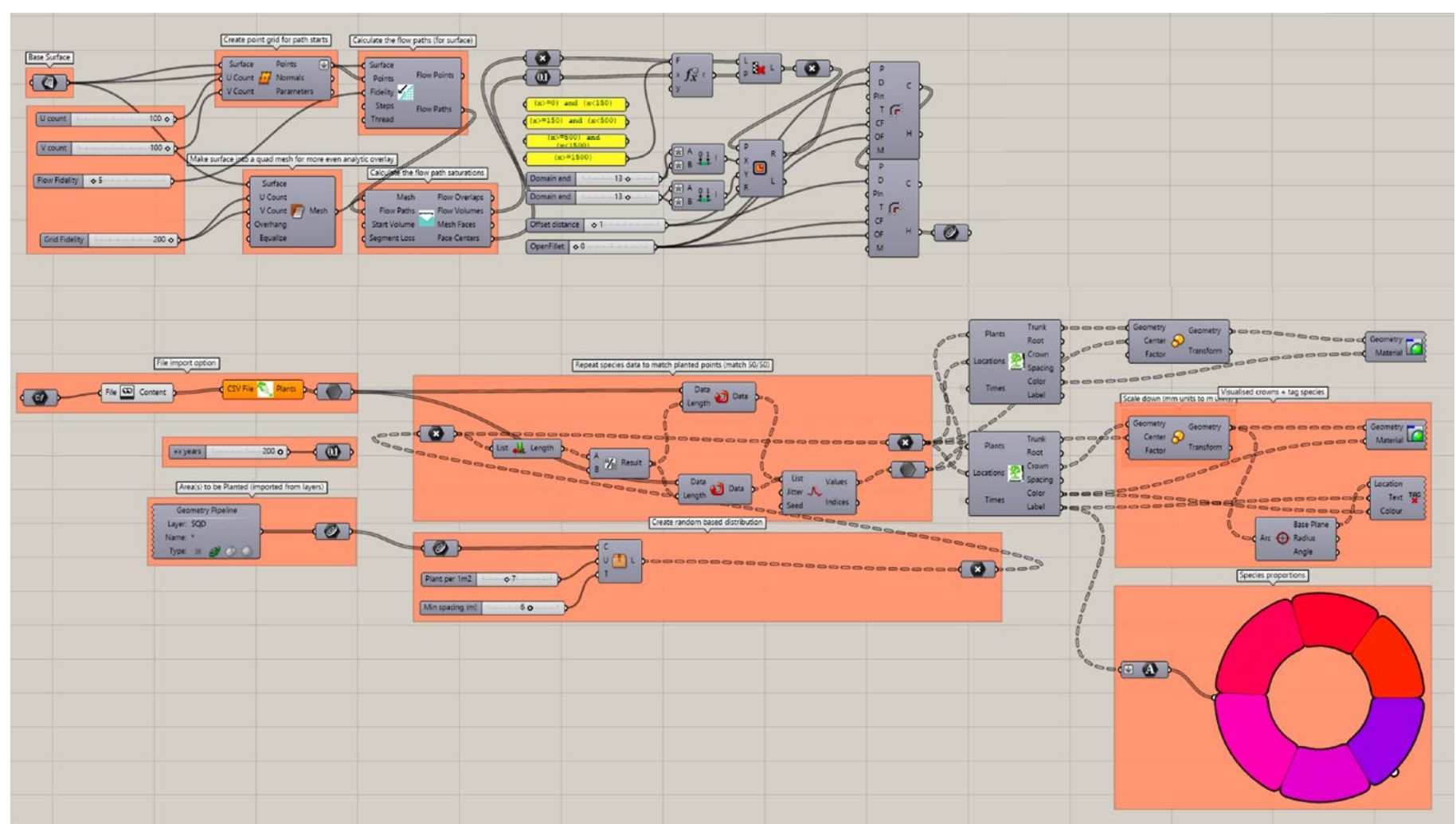

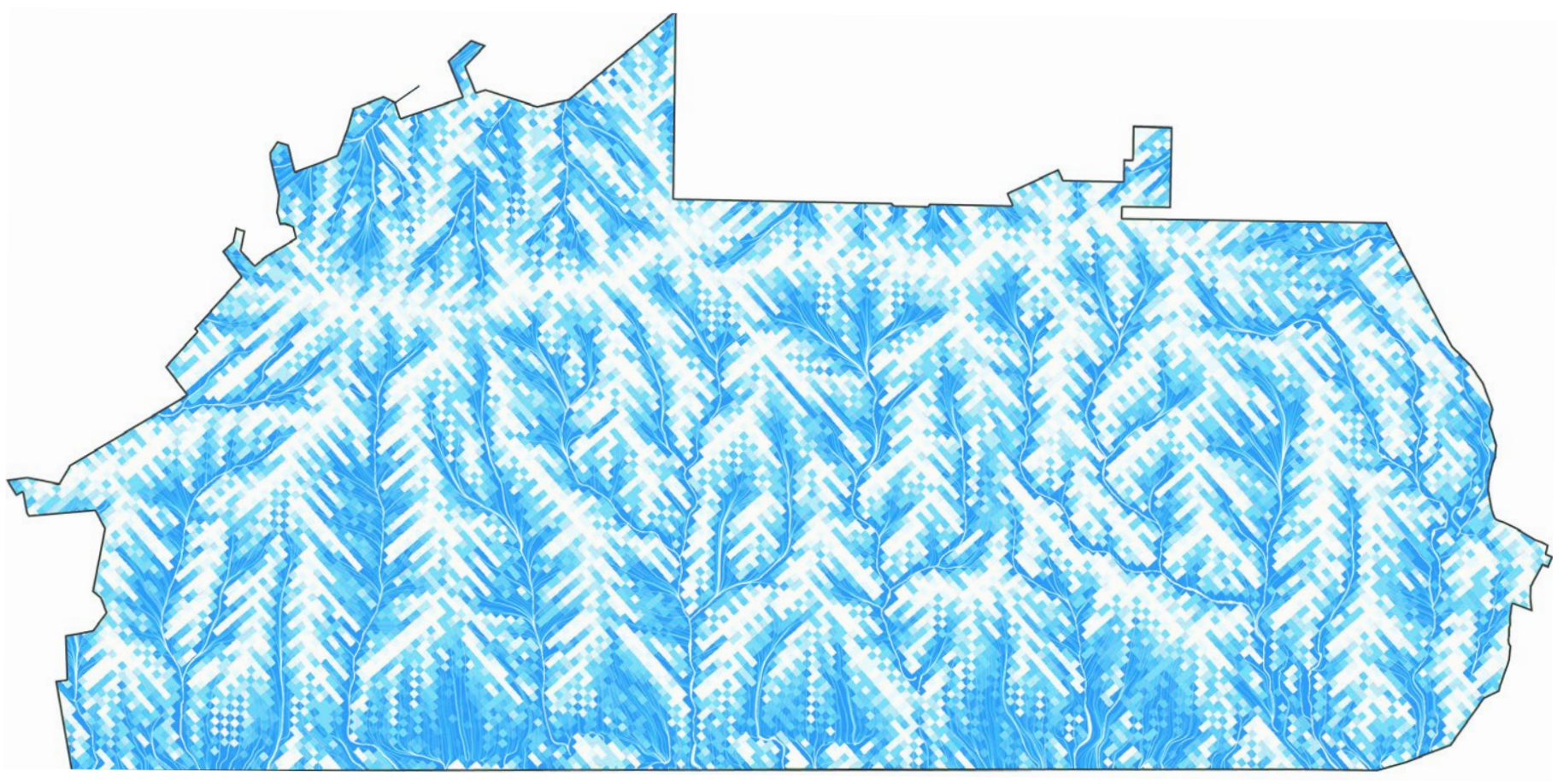

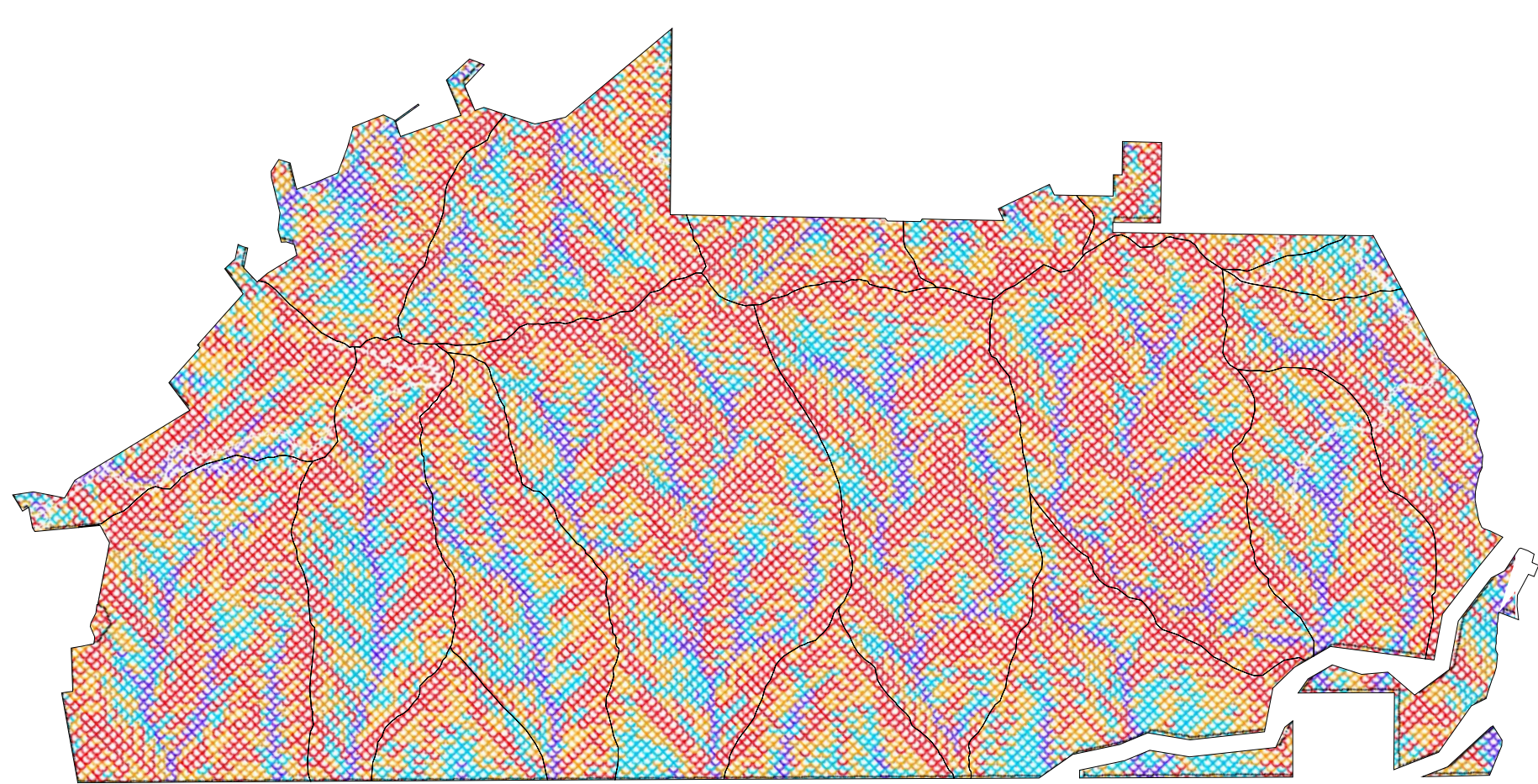

PARAMETRIC PLANTING

Moisture regime

Attributing species based on a moisture regime derived from topography. Dampest areas are attributed to most component, the flow paths themselves are used to find highest density of points. The points then are attributed to moisture level. Red $=$ Dry, Dark Blue $=$ Damp. The points are then used to create boundary lines to define the area to be planted. 


\section{PARAMETRIC PLANTING}

Vegetation Masterplan

Close up of species at 100 years maturity

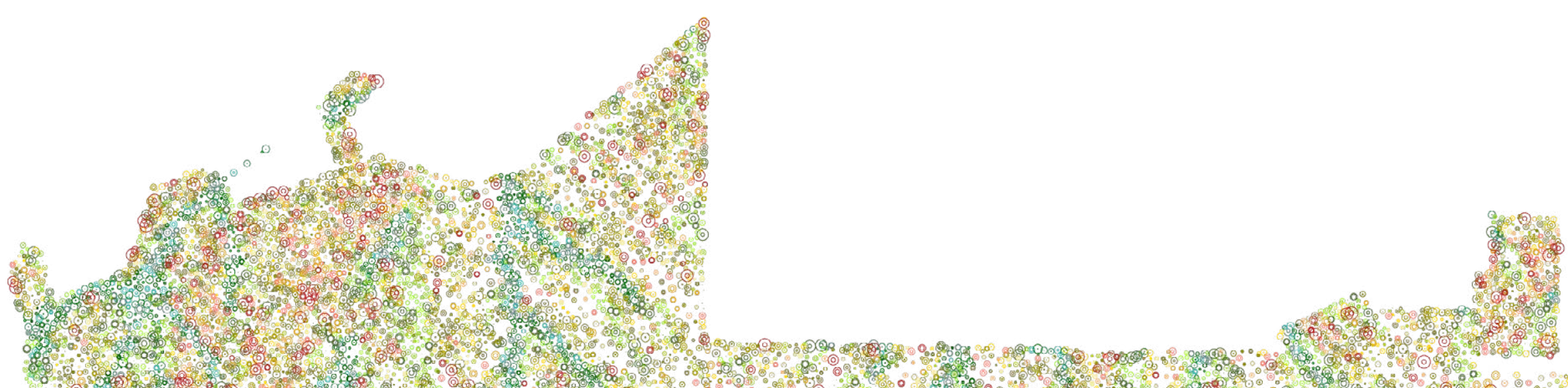

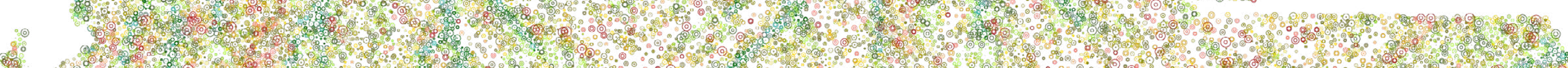
J 6.8.9.6. -3.

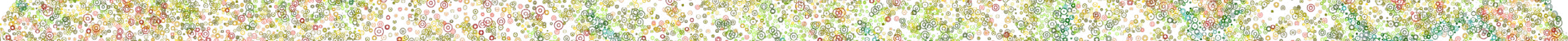

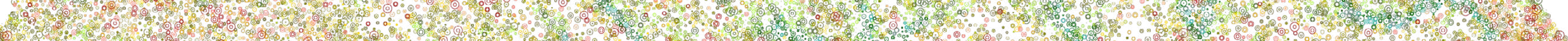

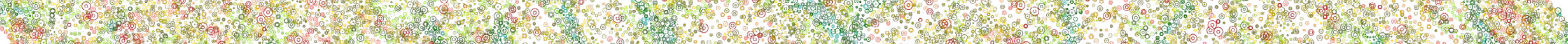

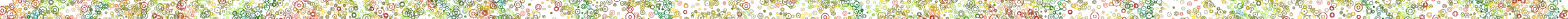
$\begin{array}{lll} & \end{array}$

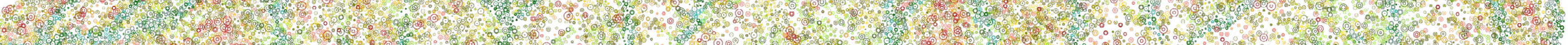

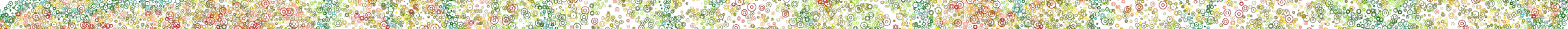

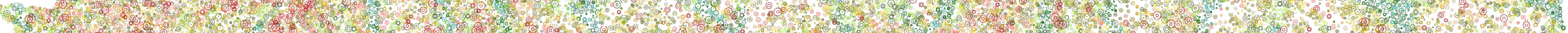

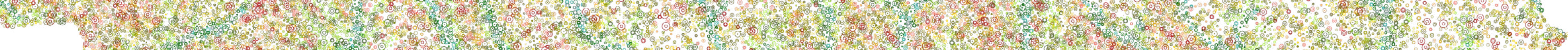

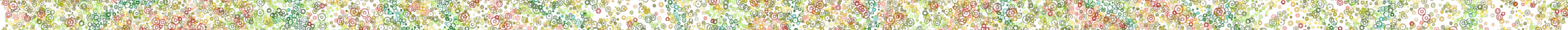

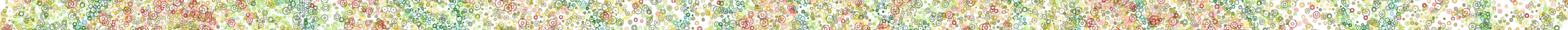

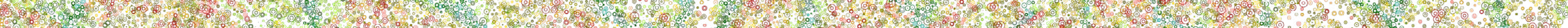

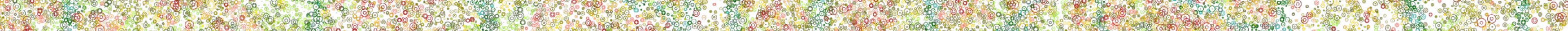

Or. A.

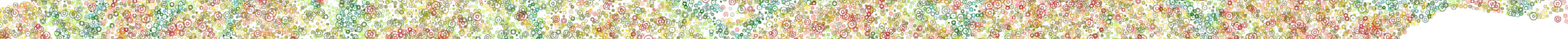

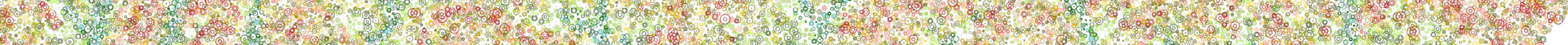

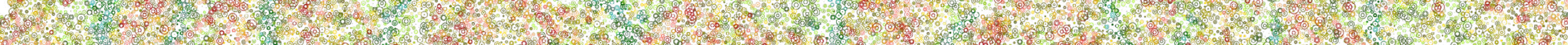
Q F.

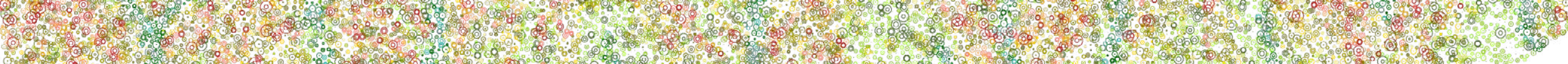

Here the 27 species of native plants drawn from regional ecology studies are distributed across the site based on of someone. Plants like Fuchsia, Pukatea and Kahikatea occupy the dampest areas and the driest by Kamahi and Totara. Species are represented in colour by moisture tolerance. Blue $=$ Dampest, Red $=$ Driest. Trunks and canopy are represented to give a better understanding of the spaces created below canopy. Spacings and randomness can al be altered, which could be used the create variation in density of forest. Semi-random grouping could create groves of the same species in areas where this might heighten a certain experience. Parametric planting provides a projected future and maturation rate and distribution of species. 


\section{NATIVE PLANTS FOR CASKETS \\ In Europe and America, willow canes are often utilised for the purpose of making natural burial caskets. Native flax caskets are available in New Zealand, but there are many other species worth exploring.}

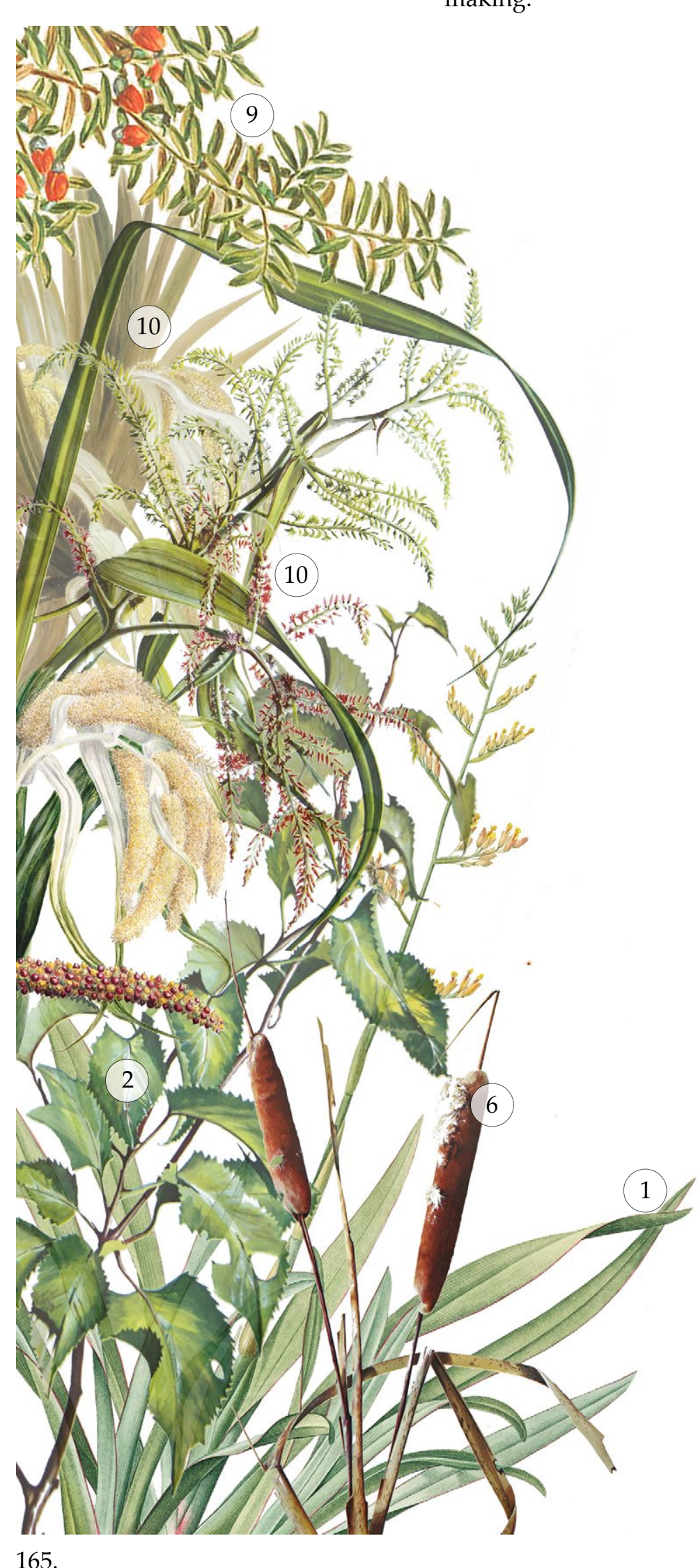

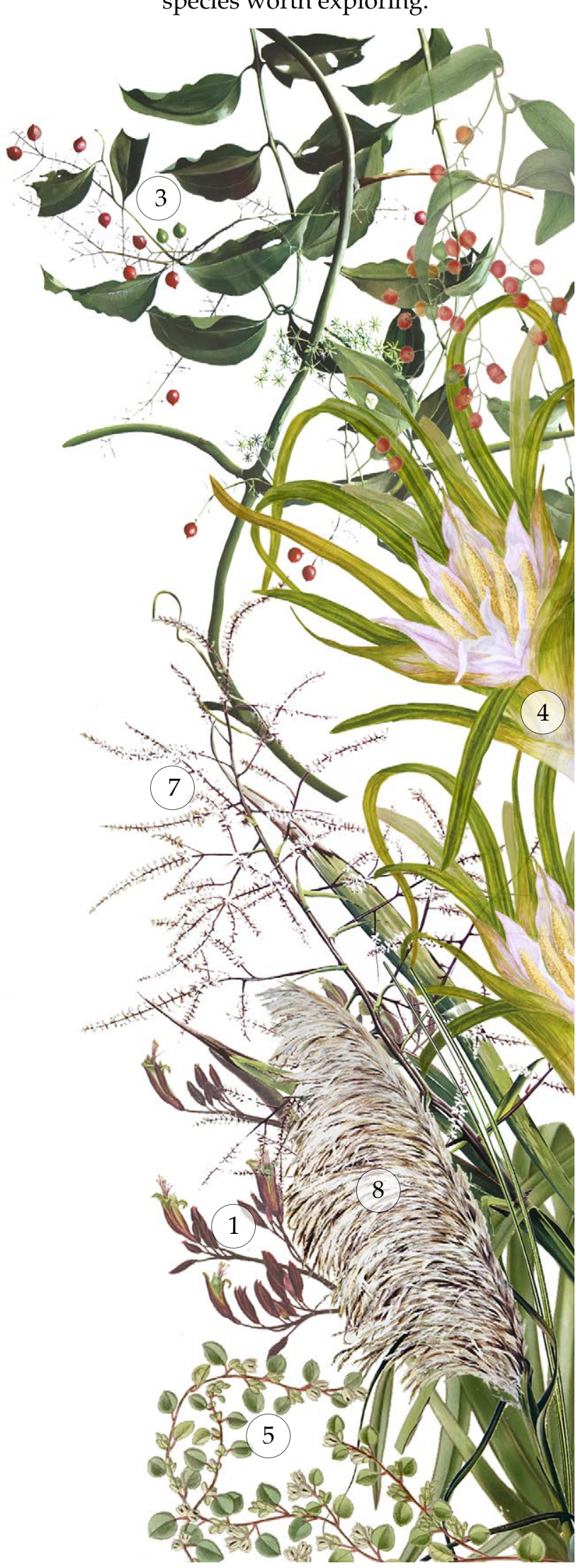

1. Harakeke - Phormium tenax 1. Traditional Use

Fig 31.

Harakeke is synonymous with weaving. Wahakura are traditional baby basinets woven from flax.

Potential Use

This content is unavailable. Please consult figure list for further details.

By upscaling wahakura a casket can be made. From cradle to grave.

$\begin{array}{ll}\text { 2. Houhere - Hoheria sextylosa } & \text { 2. Traditional Use }\end{array}$

Fig 32. The fine lace-like inner bark has been used as trim for hats, baskets and as a type of cloth.

\section{Potential Use}

The delicate paper could be used as a veil over the deceased in open

3. Traditional Use

3. Kareao - Ripogonum scandens

A very strong vine used in basketry, fencing, tool handles and fishing

traps.

Potential Use

Kareao vine could make strong woven inner frames for caskets, which could be further woven with other plants.

4. Kiekie - Freycinetia banksii 4. Traditional Use

Fig $34 . \quad$ A climbing plant whose waterresitant leaves and aerial roots were used in clothing, mats and rope.

\section{Potential Use}

The aerial roots and ability to make rope are useful in lashing and handles for caskets.

5. Pohuehue - Muehlenbeckia complexa

Fig 35. A scrambling plant with fine decorative vines used in basketry.

\section{Potential Use}

For decorative inter-weaving with Kareao. 


\section{Raupo - Typha orientalis}

Fig 36

This content is unavailable.
Please consult figure list for
further details.
further details.

\section{Ti Kouka - Cordyline}

australis

Was used in all aspects of woven
items, its fibre when made into rope
is stronger than flax.
Potential Use

Rope for lifting and lowering casket into grave.

\section{Toetoe - Cortaderia fulvida 8. Traditional Use}

Fig 38. The straight hollow canes are used in tukutuku panels on walls.

\section{Potential Use}

Inter-weaving in caskets.

9. Totara - Podocarpus totara

Fig 39. The flaky bark of totara was used to make a particular type of basket known as Patua.

\section{Potential Use}

Strengthening liner in caskets.

10. Wharawhara - Astelia

3. Traditional Use

hastata

Fig 40. An epiphyte used to make snow sandals, mats and baskets.

\section{Potential Use}

For decorative inter-weaving with other species for different hues.

\section{BURIAL IN THE}

\section{FOREST}

Challenges are posed in the logistics of burying around trees and in rocky ground.

All tools must be able to be carried to a burial plot by a people on foot, the density of forest prohibits digging graves with large driven machinery. Focus is placed on portable means of grave digging.

Care must be taken to site burial away from the drip-lines of larger trees whose roots pose problems to digging.

d

Power Tools

\section{Chainsaw}

Where larger diameter roots are encountered.

Jackhammer

For very hard ground and lots of

Machine Auger

Useful in speeding the process of digging burial urn holes, the smal diameter of the hole can be drilled out quickly.

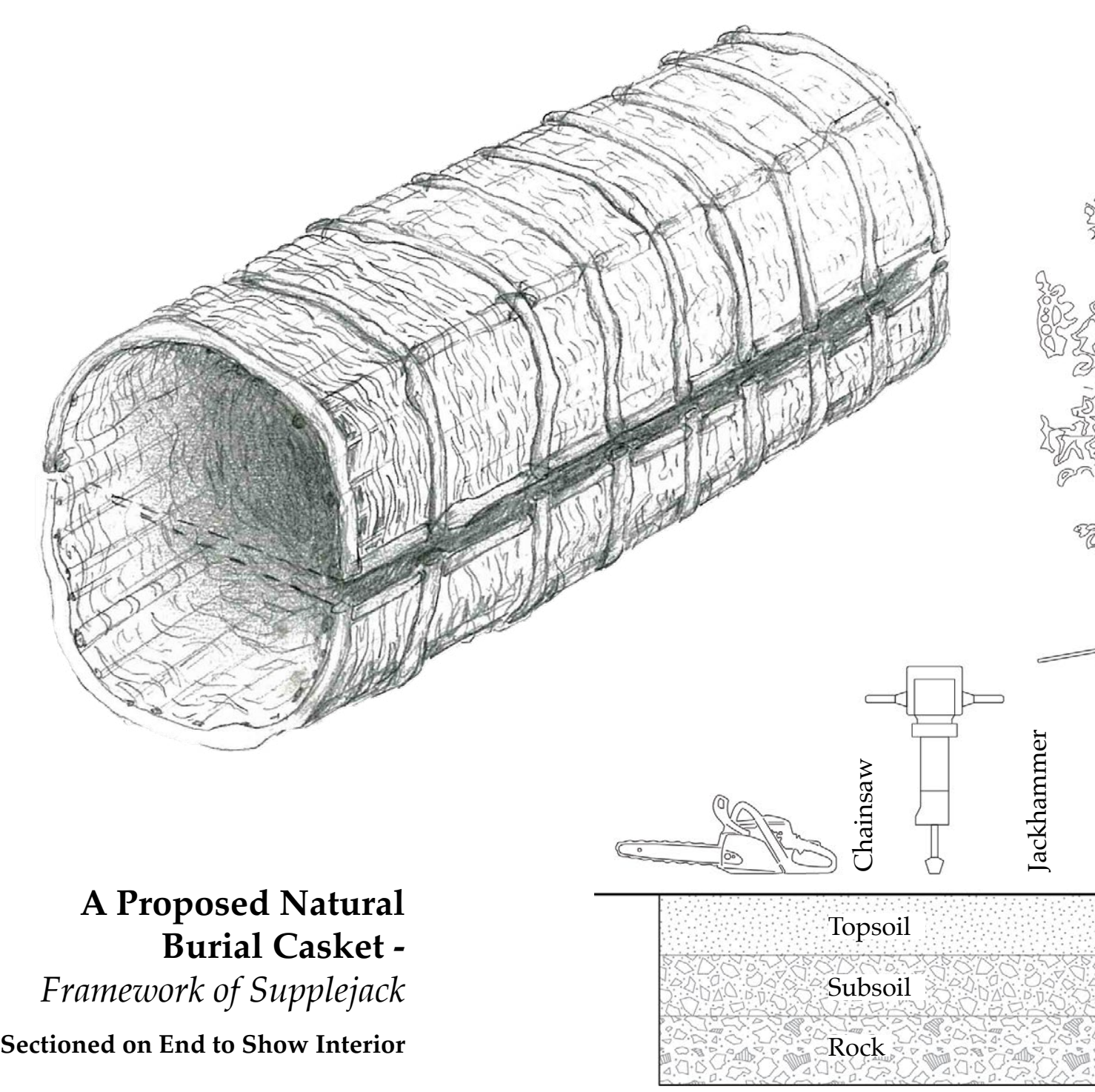

Hand Tools

Spad

The quintessential tool in the grave diggers arsenal. Used to mark out a grave and dig out most material, but

Pick

Useful for loosening soil and breaking rock.

Root Spud

A sharpened flat instrument, used to chop through smaller diameter roots.

Digging Bar

When power and leverage are needed to move or break large rocks. 


\section{Preliminary Forest Burial}

\section{Design}

Parametric planting is useful for understanding how plants can be distributed throu plants can be cemetery. How might these different areas of vegetation be experienced and combined with burial?

Preliminary designs of forest burial focused on differing landforms and vegetation experience in $\mathrm{T}$ Ahumairangi.

It tries to bring together a range of relationships between burial and lifeforms. For example, in the rocky slopes, stones may be piled atop the deceased to mark their place. (Geolocation apps common in natural burial sites would be used in tandem). A top these rocks, hounds tongue fern and a fragrant fern are likely to grow. The stone moth (Cherasdula sp.) would benefit from the increase in habitat, insectivorous birds like the fantail - piwakawaka, wound in turn benefit from their increase. Bird guano dropped here can further the growth of ground dwelling plants and a forest species like rimu can be further planted to mark the dead.

Within the aging and decaying pine forest, burial urns could be placed within rotting stumps. Wood loving fungi spores could be integrated with the urns to speed decomposition of the pine, releasing nutrient for native forest to grow.

Here the concept of utu (that which is reciprocally connected between past, present and future) is explore through these burial methods which might facilitate these connections.
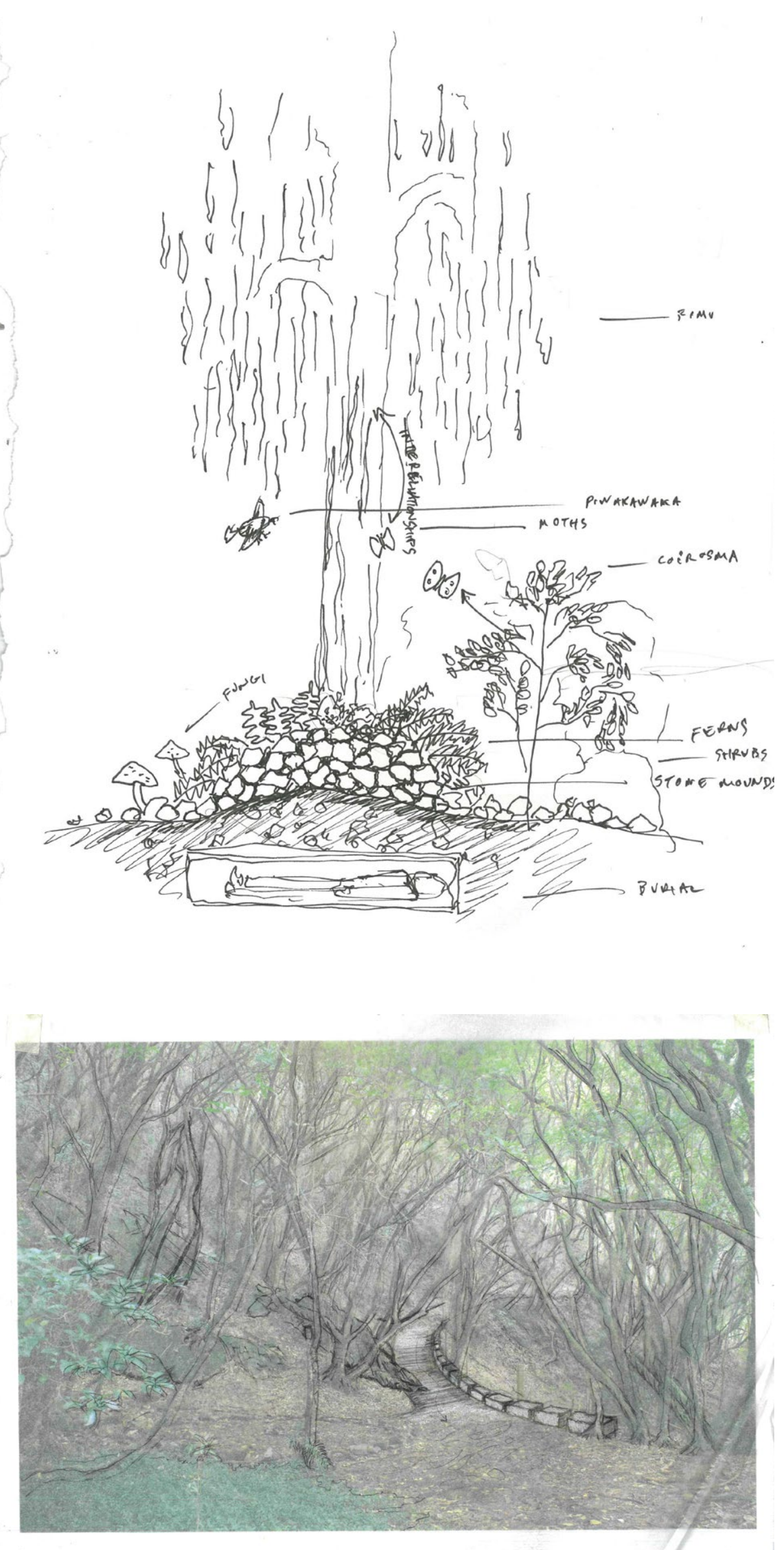

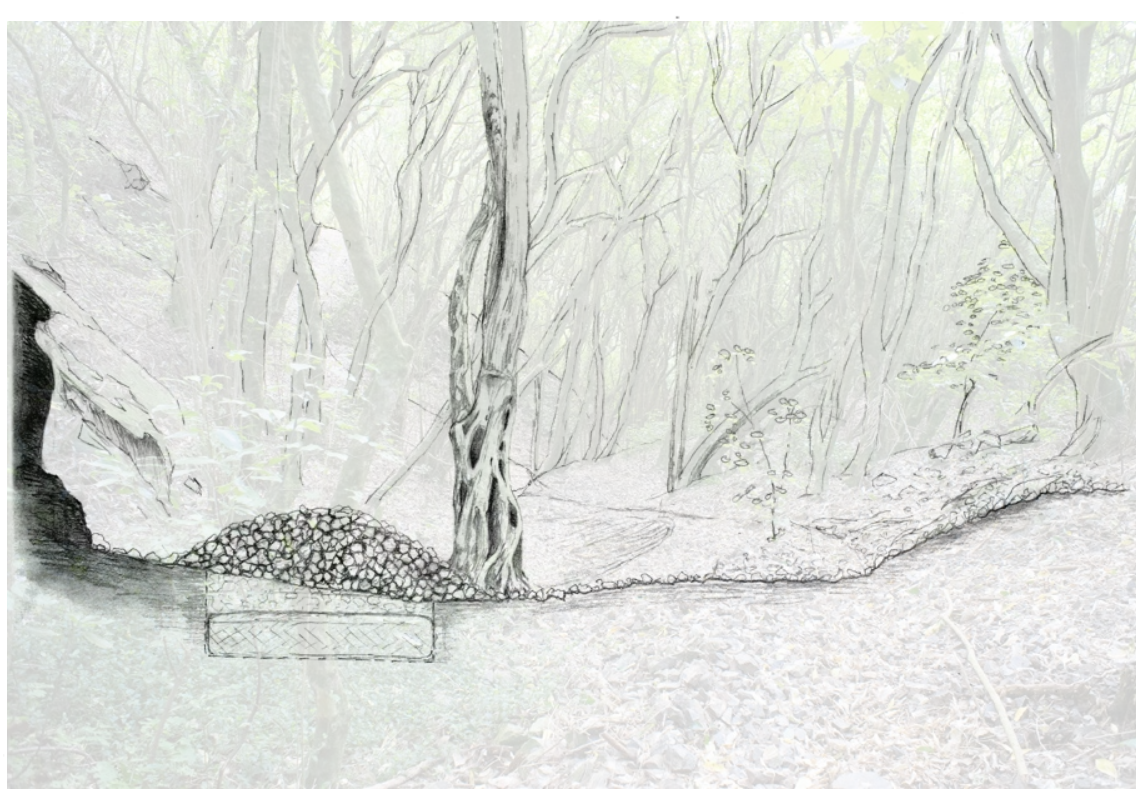

Scree slope

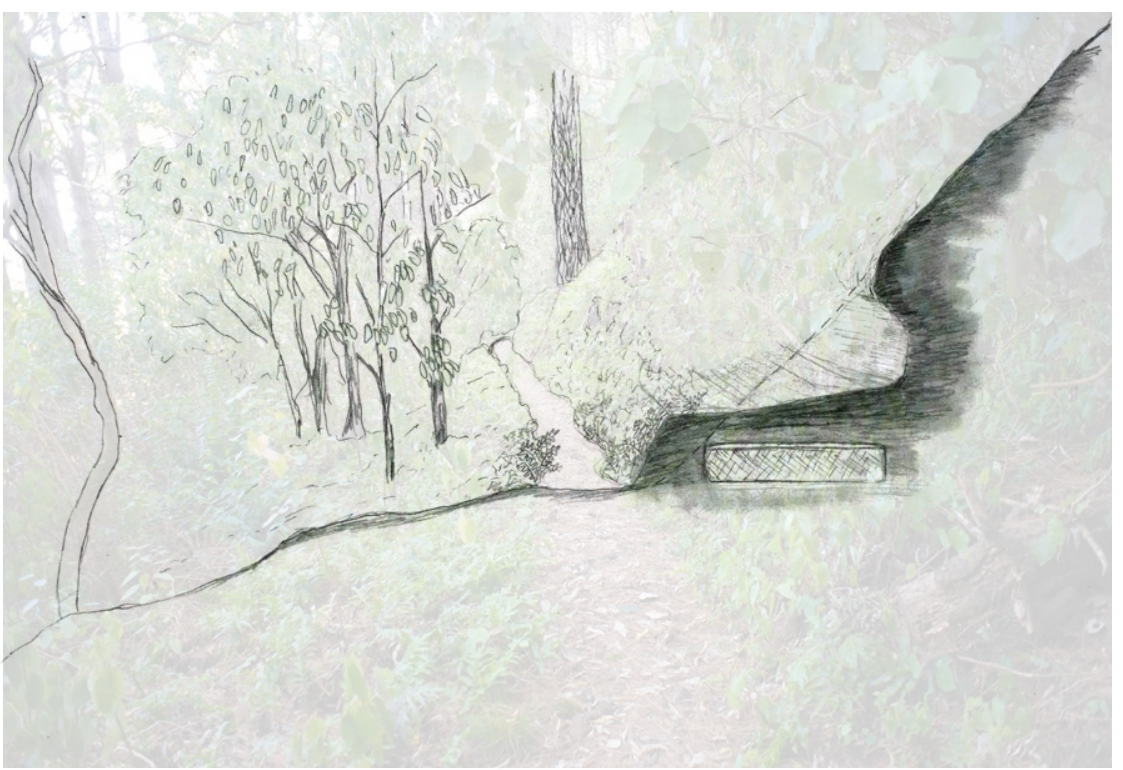

Dry Bank

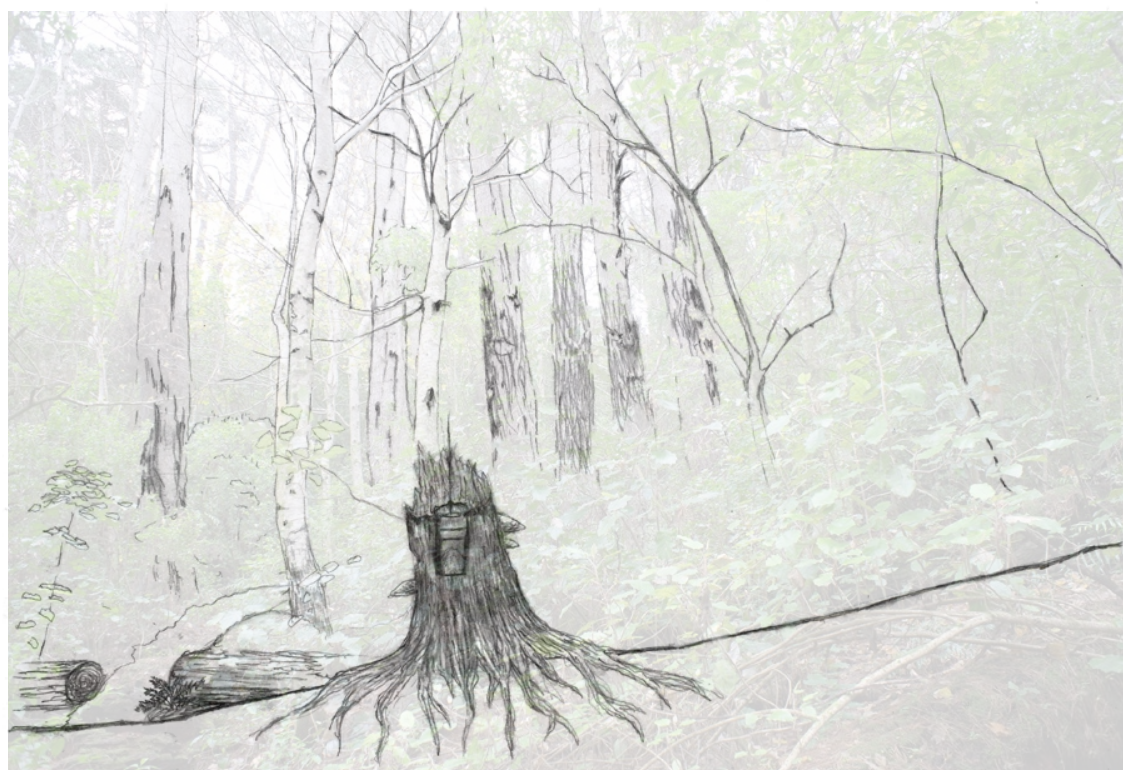

Valley Pines

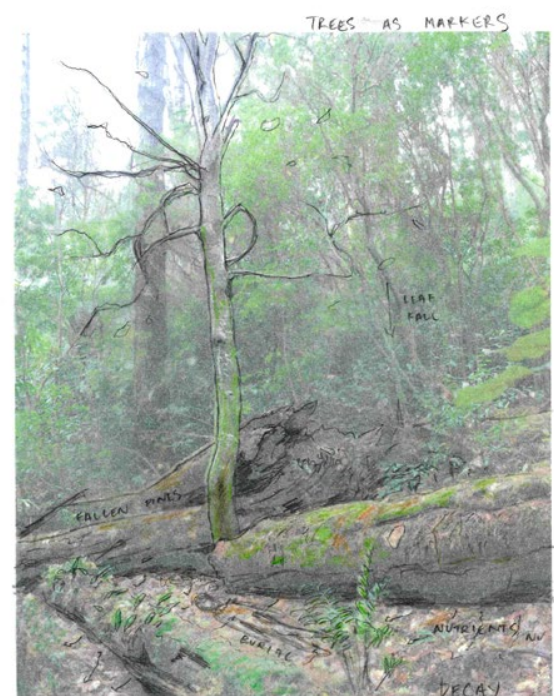



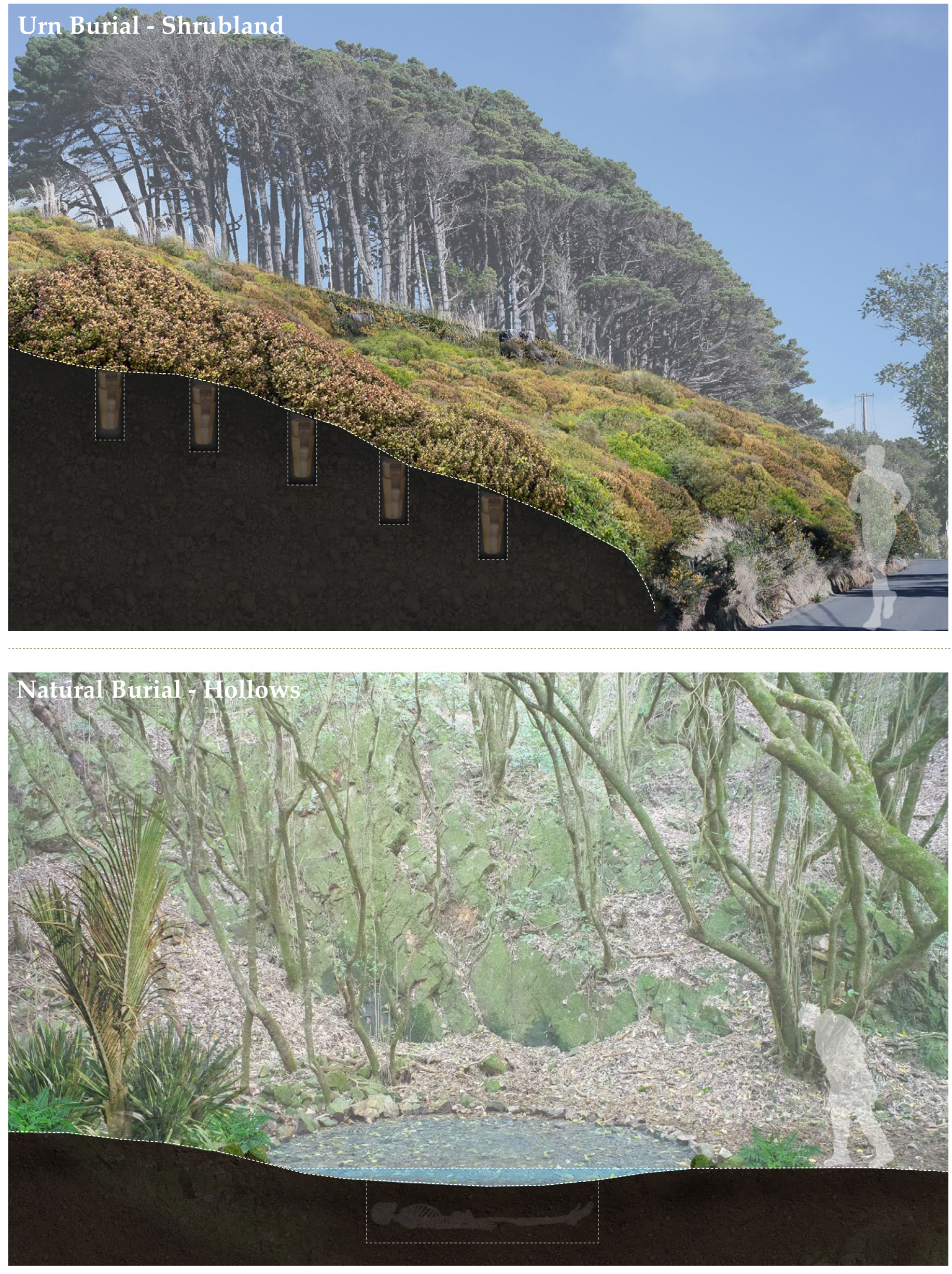

\section{Forest Burial Design}

Suitable Topography

This particular area is near the Weld St entrance and is currently gorse dominanted. The burial of urns with proposed flora atop, would create an ecology similar to that of Belmon Reserve. It would provide a range of habitat for shrubland species and can bring an ecology into relationships through burial.

This can revegetate steep areas owing to the ease of burying a small urn.

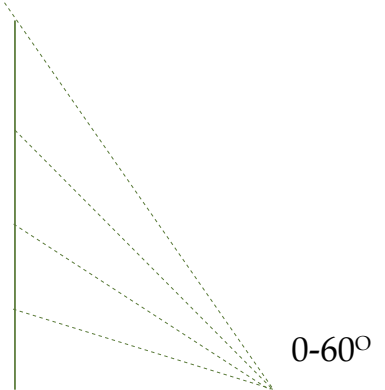

If a small depression were to be left atop graves, it would allow the land to hold water ephemerally. This would benefit a range of fauna like mudsnail. The increase in moisture might provide a niche for species like Hydrocotle, which in turn would increase the presence of Scoparia moth as greater amount of food is available.

This is mostly possible on shallow slopes.

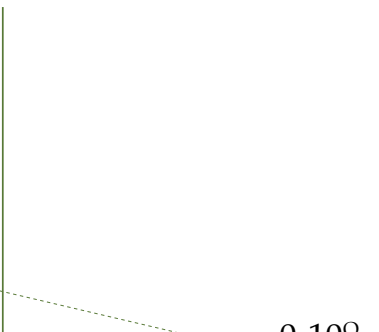

Flora Possible Fauna \& Fungi
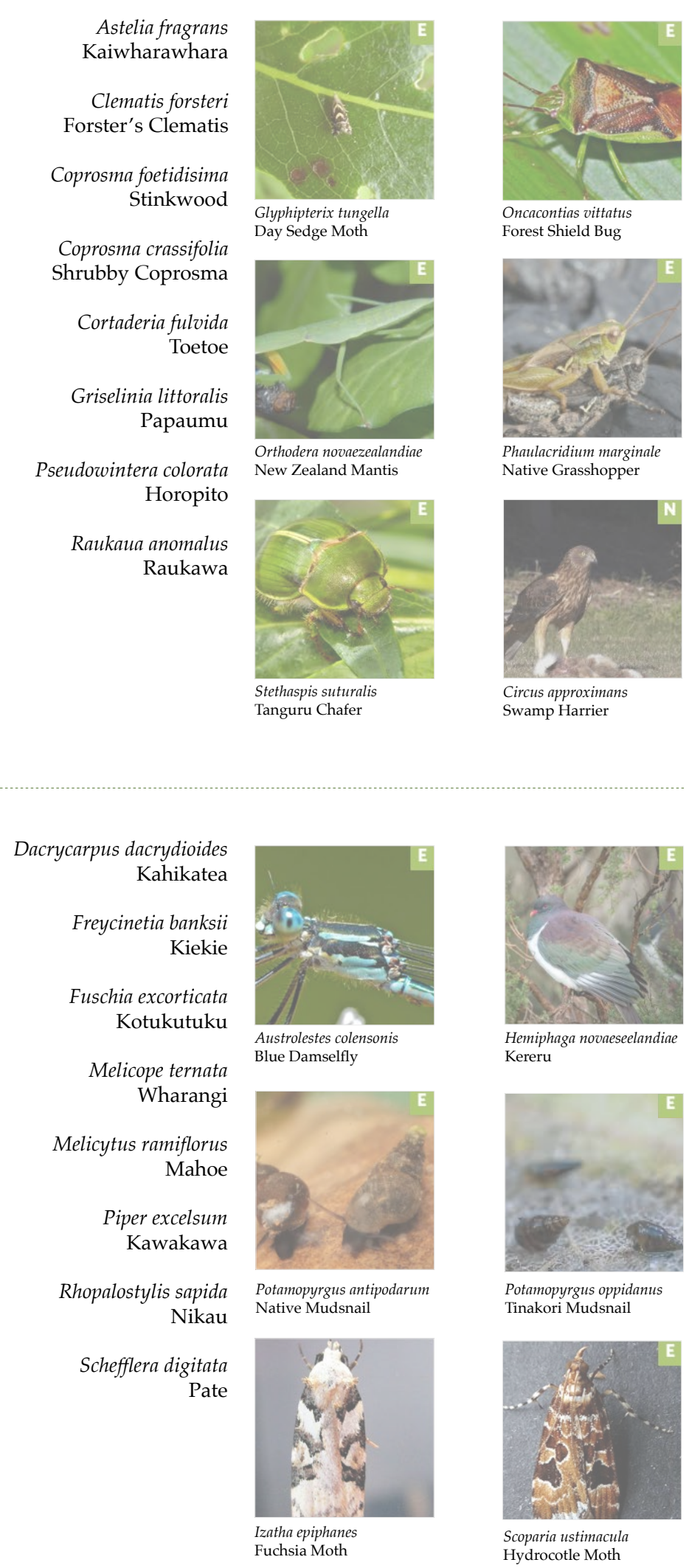

Hetiphagan novaseselandiae
Kereru

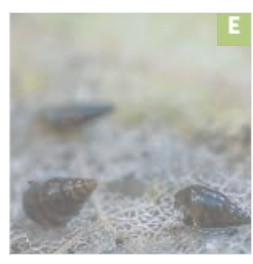
Potamopyryus sppidanus
Tinakori Mudsnail

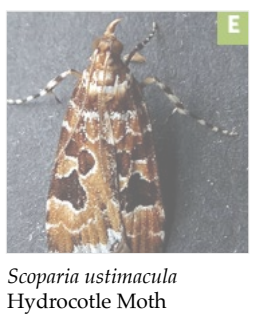



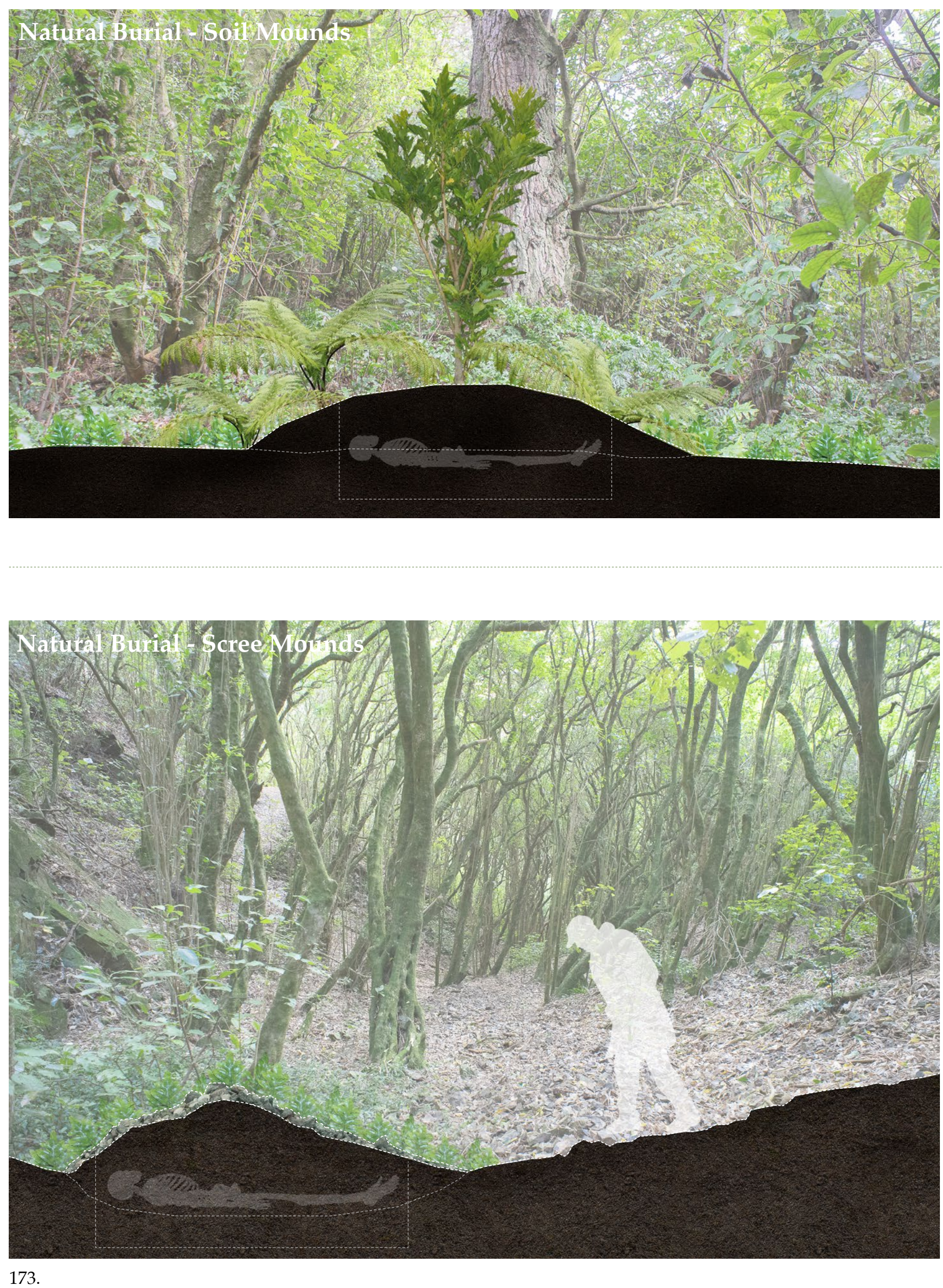

Soil mounds are created by the

displacement of earth by the

deceased. A top these drier micro

topographies, hounds tongue fern is likely to colonise. These verdant green mounds could create a unique experience in cemeteries. This

would be in the forested valleys of

Te Ahumairangi, species like tui

might benefit from the winter nectar

produced by kohekohe.

The looseness of soil restricts this method to flatter slopes, where the soil is less likely to wash out.

$0-20^{\circ}$ In scree valleys, stones may be piled
atop the deceased to mark their place. Atop these rocks, hounds tongue fern and a fragrant fern are likely to grow. The stone moth (Cherasdula sp.) would benefit from the increase in habitat, insectivorous birds like the fantail - piwakawaka, wound in turn benefit from their increase. Mahoe and kawakawa provide food for their respectively named moths. The fluffy Stereocaulon fungi would have an increased habitat of disturbed rock.

This method could work on higher slopes as the rock covering prevents erosion. Over time as stone falls down from the ridges, the deceased rock.

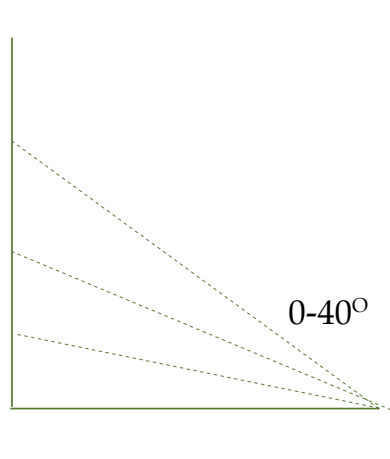

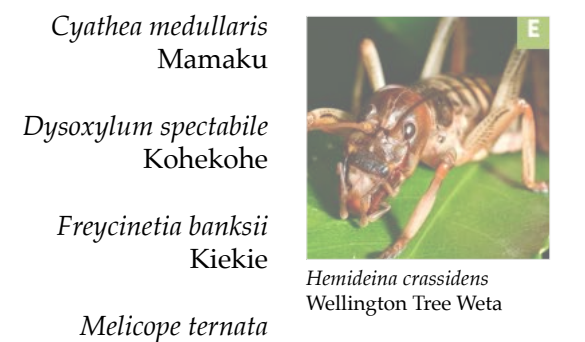
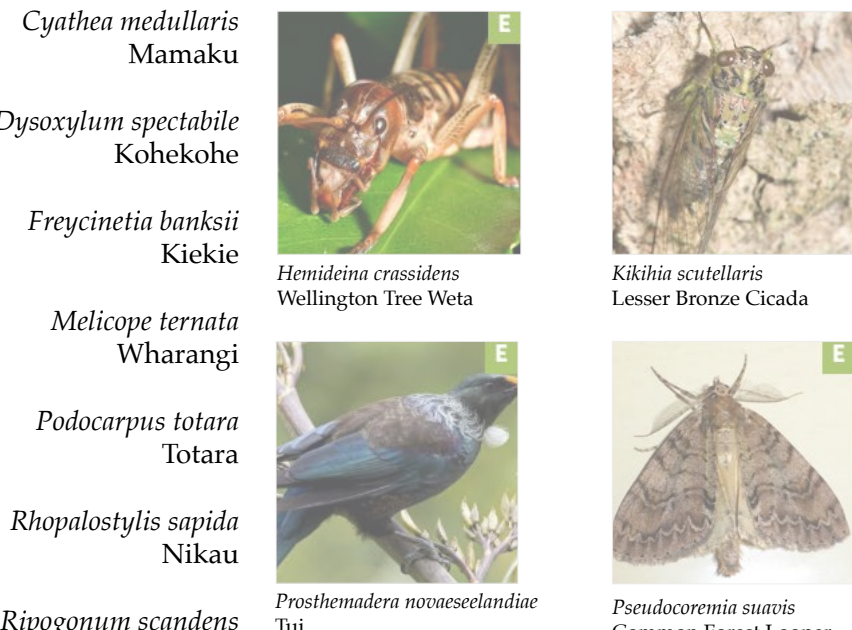

Ripogonum scandens
Supplejack
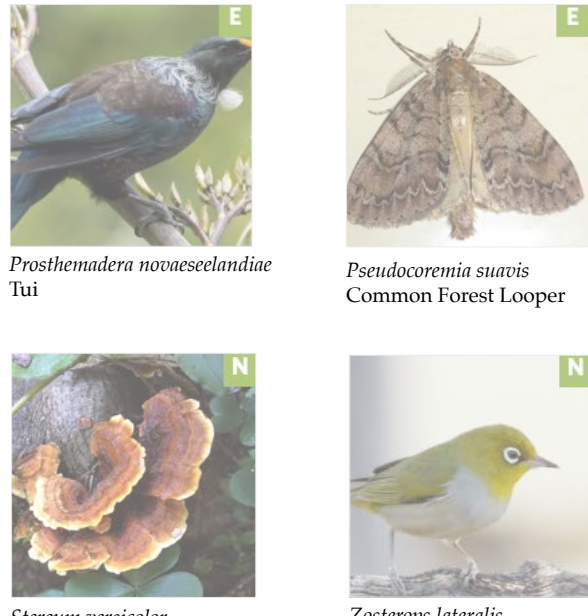

Stereum versicolor
False Turkey-tail

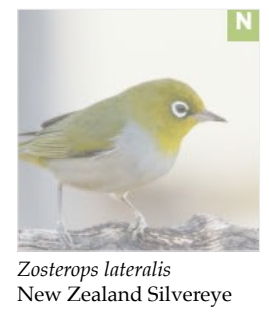

terops lateralis
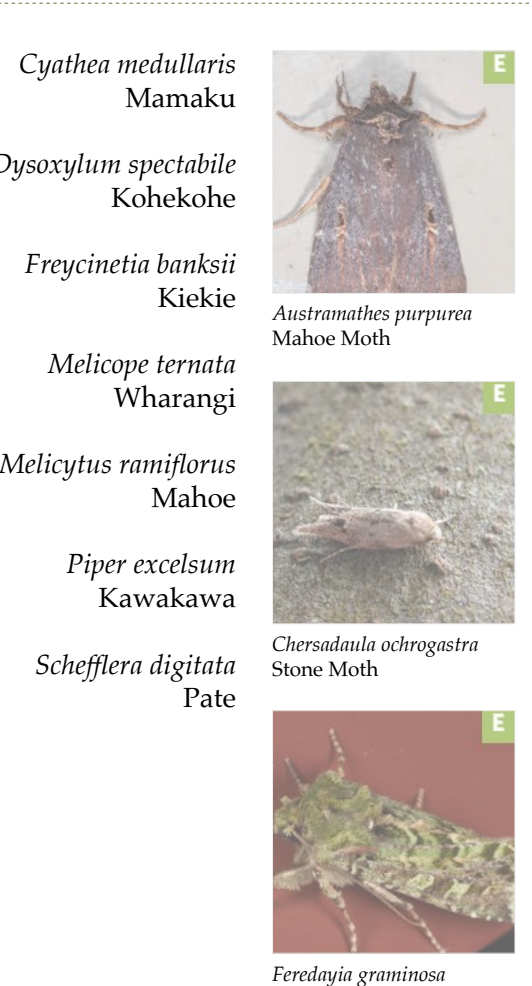

Feredaniag gramininsa
Mahoe-stripper Moth
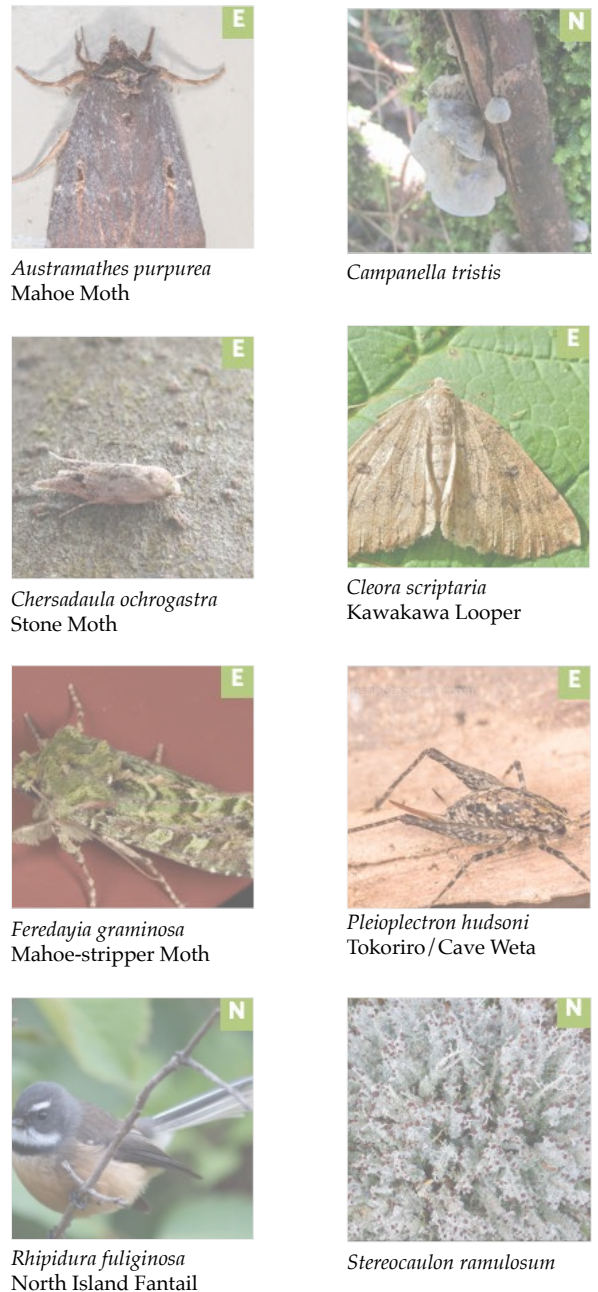

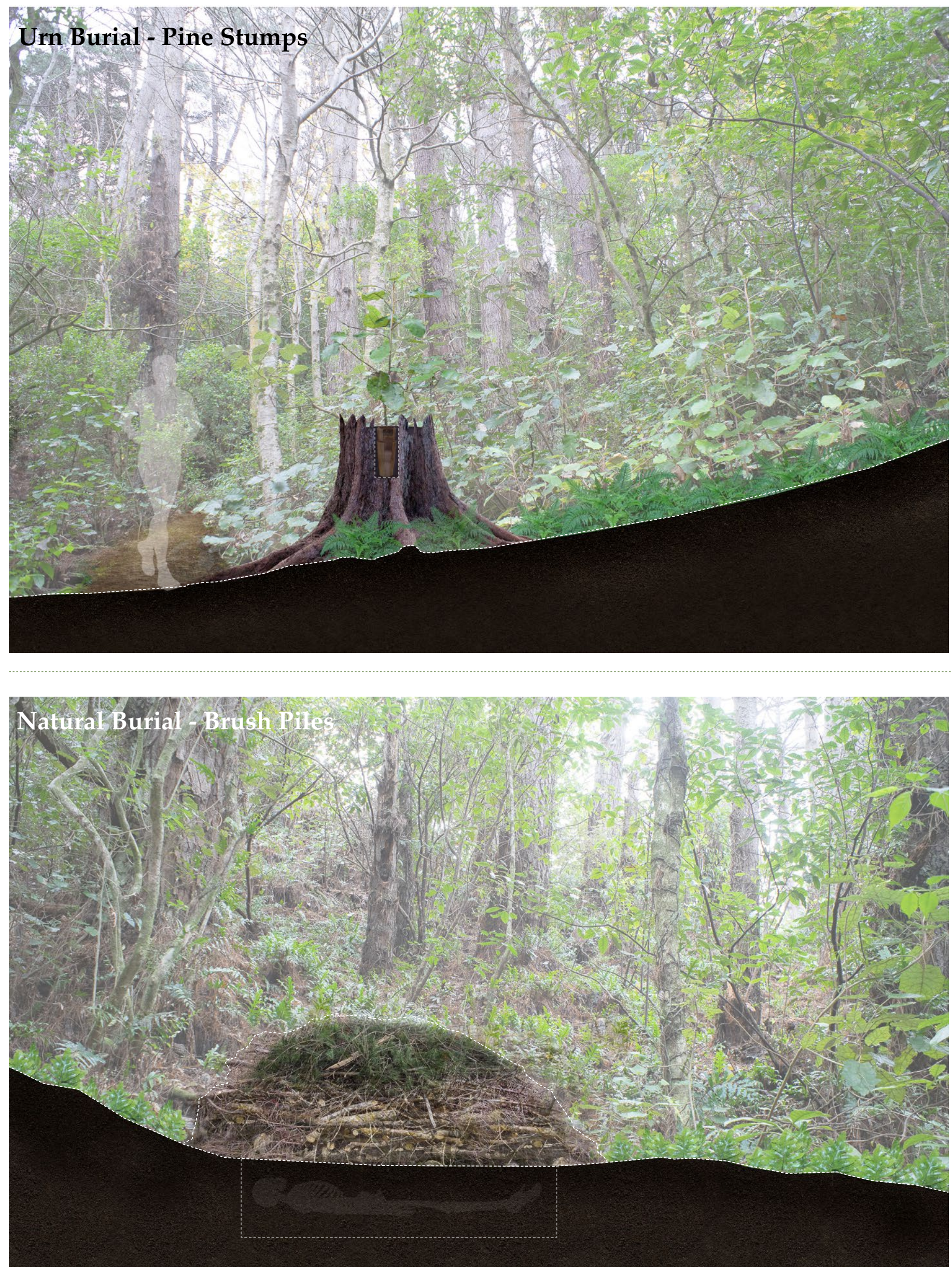

Burial urns can fit into the niches of the decaying pine stumps. The rotted wood would be easy to place or drill holes for urns. The spores of wood loving fungi may be mixed into the loving fungi may be mixed into the urn, to break down pine faster. The of fungi can mark the dead. Within these forest the call of kaka are already heard.

This can utilise any kind of slope as the burial is within a stump and not the ground. This forest would grow raised off the ground. It may potentially create an easily navigable forest.

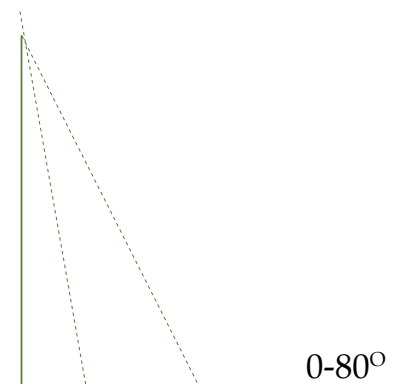

$0-80^{\circ}$

Brush pile burial can make use of material cleared from tracks and other burial sites. Within these a range of shelter habitat is provided for fungi and fauna. Bisporella fung might turn these brush graves bright yellow. A series of bright yellow mounds in the forest could create a novel kind of burial. Or the gelatinous Myxarium, a translucent mound.

The sides of valleys might be an ideal place for these.
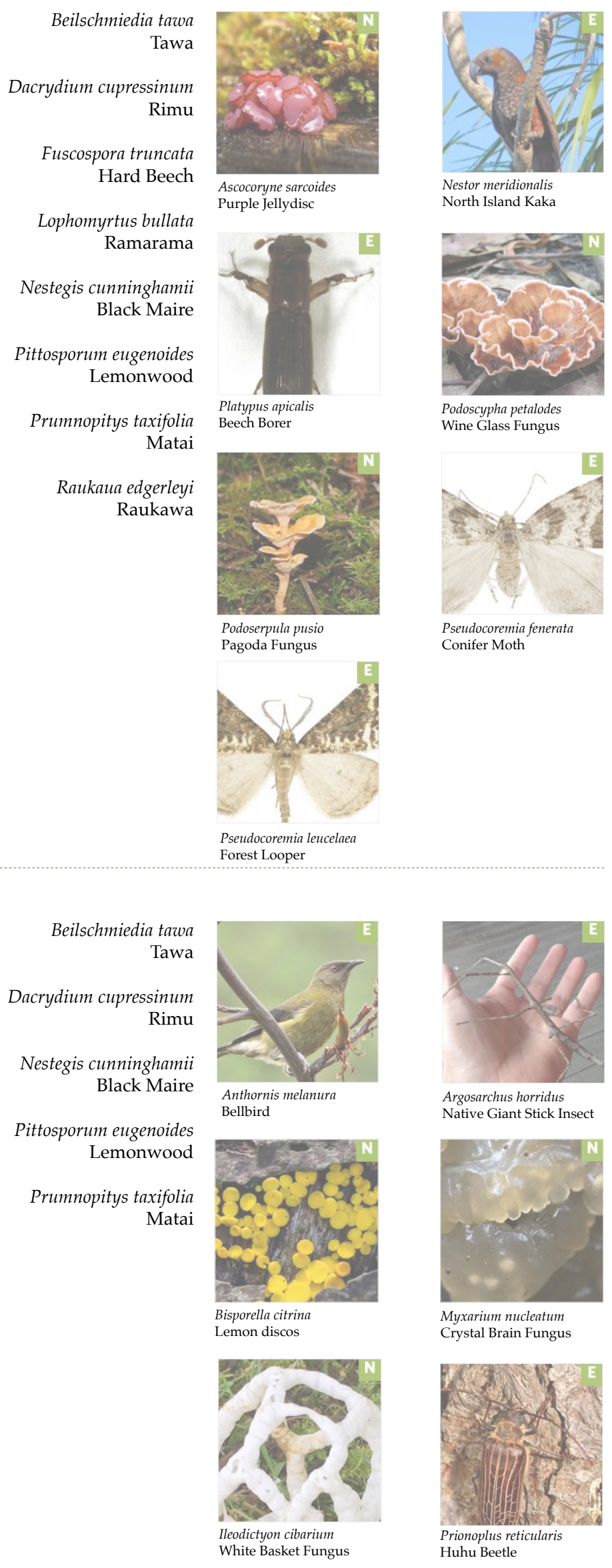

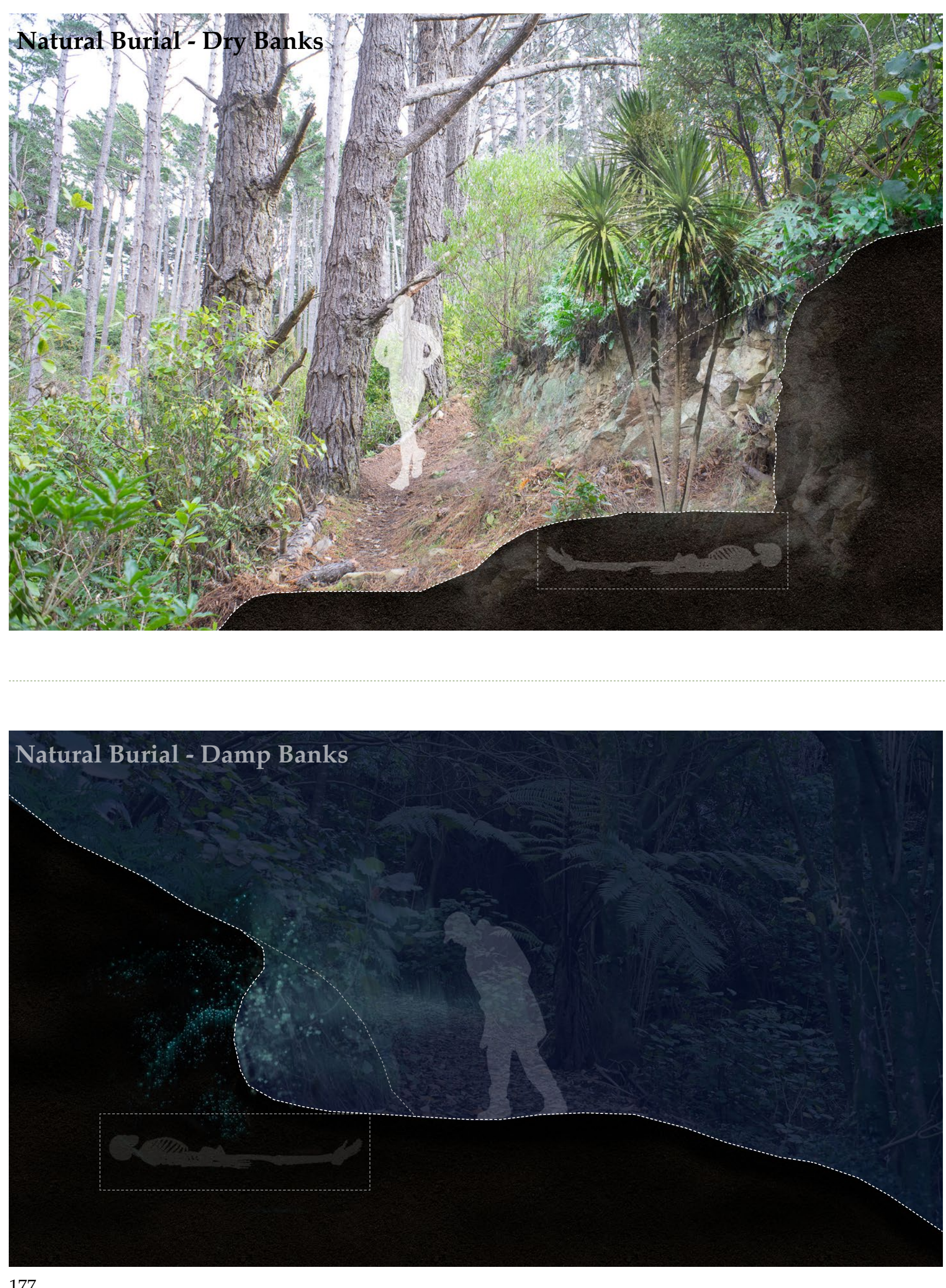

Natural burial on banks can reshape the land. Within these drier banks on ridges a range of exposed soil opportunist fungi and endangered native insects could find homes. More drought tolerant plants like five-finger and kaikomako would provide berries for the grey warbler

This can use steeper land and the soil from excavation can be used to widen many of the narrow pathways.

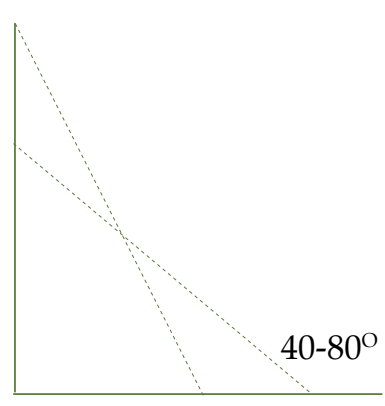

In damp banks, there is an opportunity to increase the habitat of glow-worms throughout $\mathrm{Te}$ Ahumairangi. The glowing graves can line pathways and create habitat for weta, moss moth and Carov's dragonfly. Glow-worms are found no where else in the world and they may provide a role in create a uniquely Aotearoa cemetery.

These would be in valleys were moisture levels are higher.
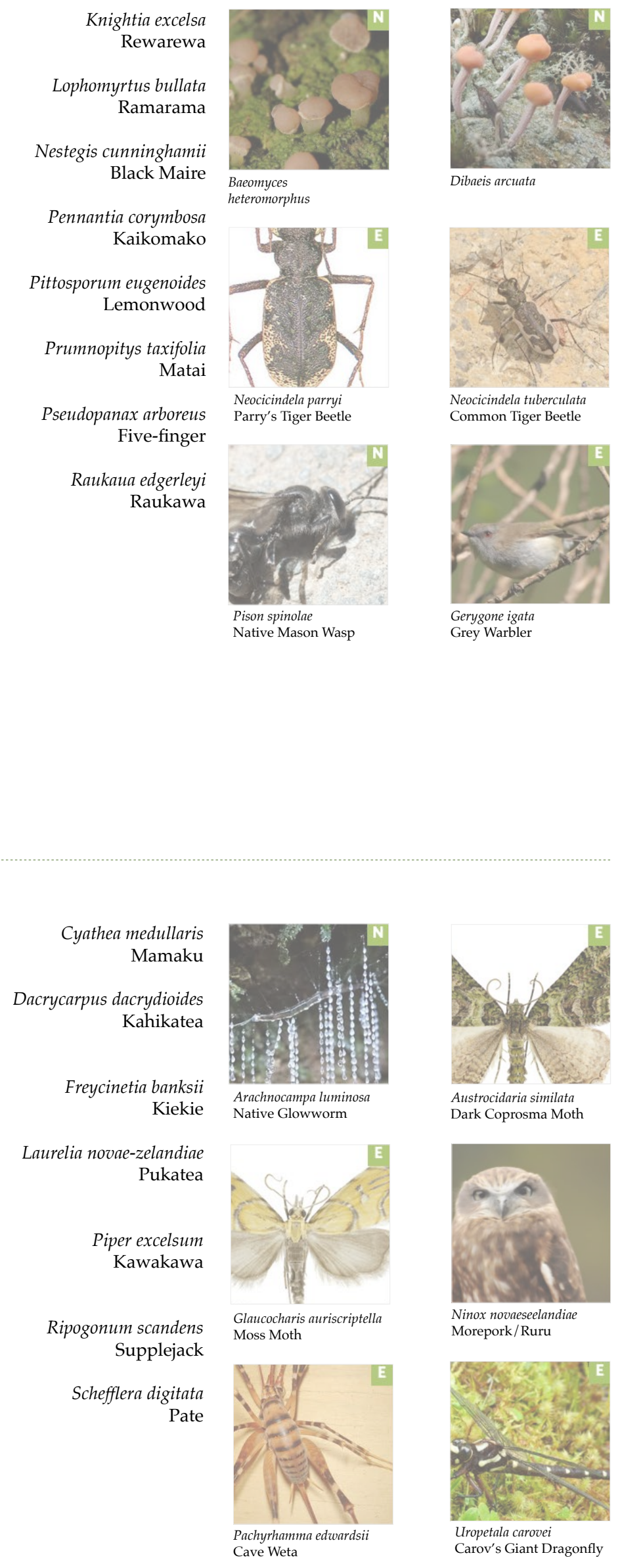


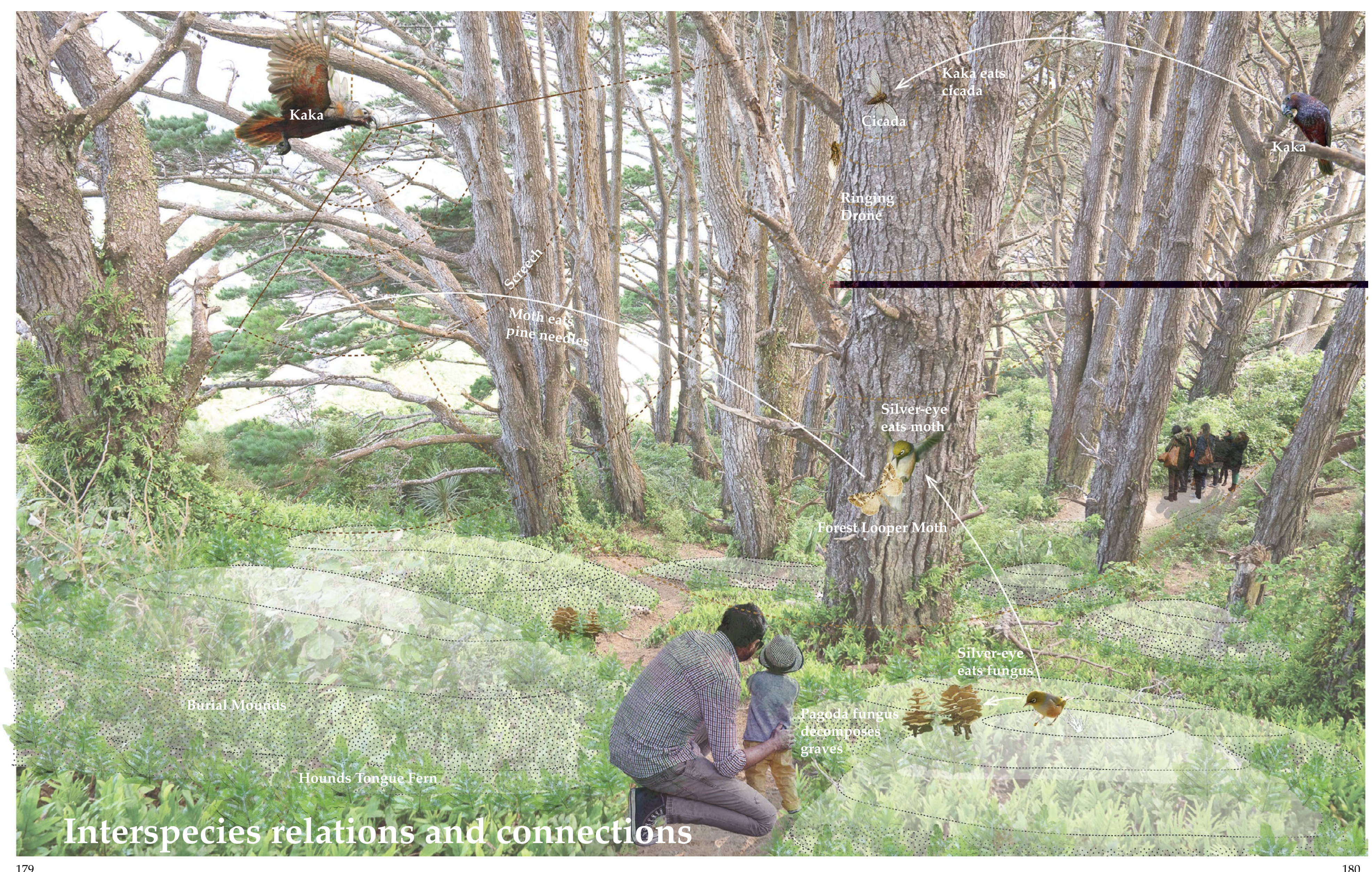




\section{Overall Design}

\section{DESIGN PHASE 2}

The site masterplan focusses on four key design areas of differing scales.

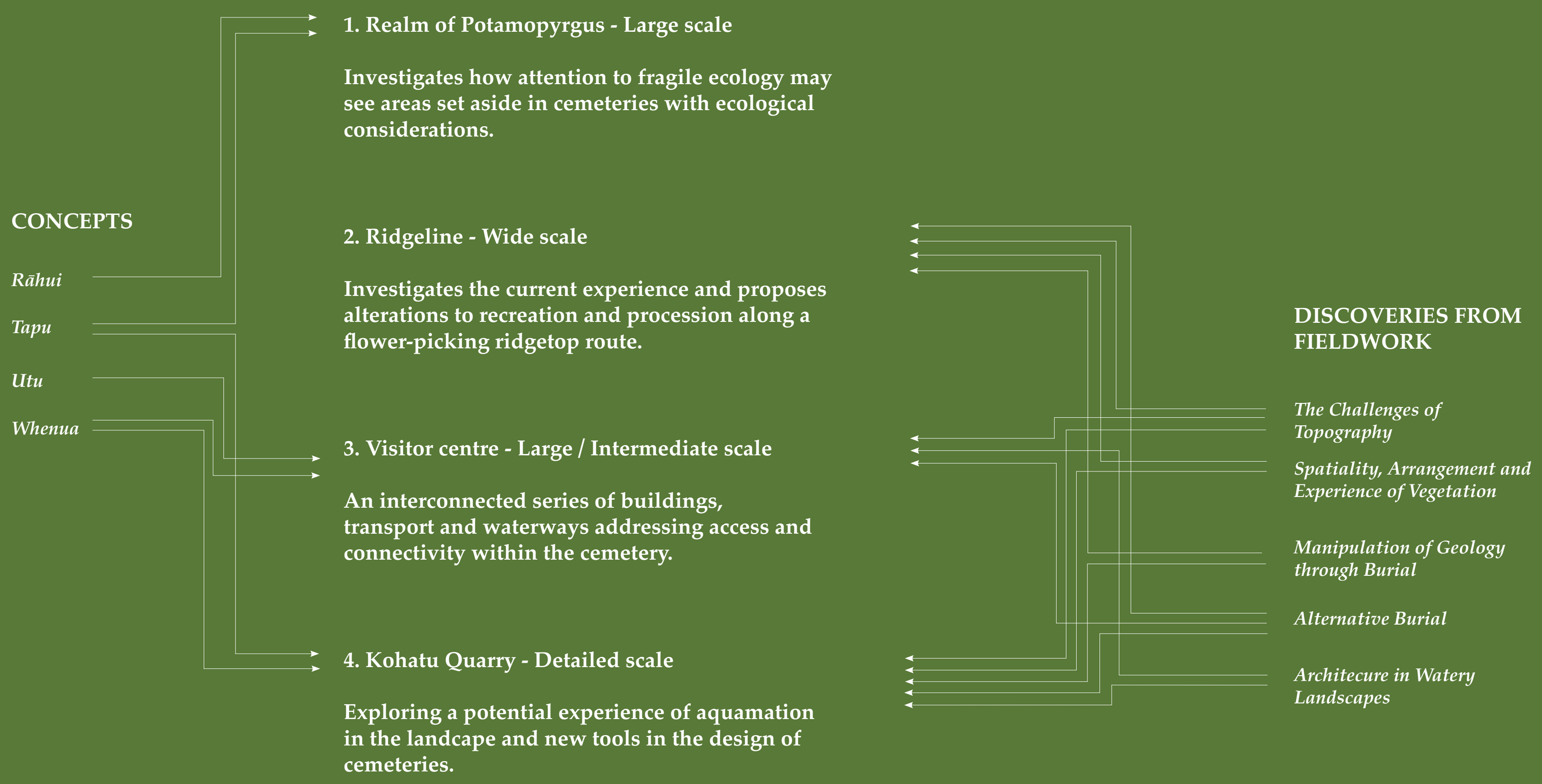




\section{Masterplan}

Burial areas named based on their character or species present.

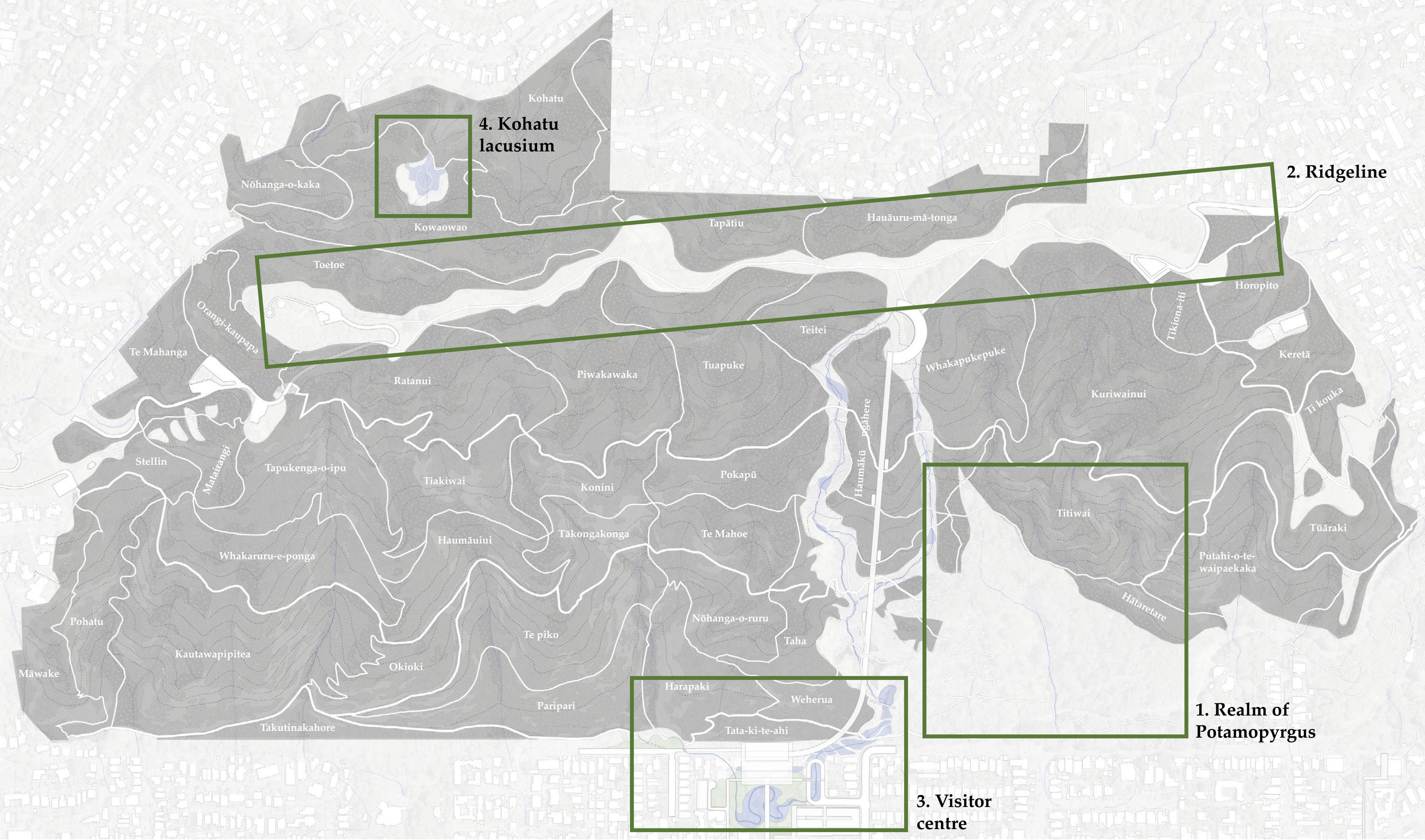




\section{Vegetation Masterplan}

The plant species that were distributed over the entire site in earlier design stages, now it covers just those areas where urn and bodily burial will occur. The family of the deceased would be able to choose from the range of tree species that have been distributed, which would be planted atop the plot of their deceased. When these trees are

planted, their location would be geo-referenced so the family can easily find their loved one. Some areas are retaine as broad scale plantings such as the zones of Hound's tongue fern, as this species already forms large carpets, burial will utilise the existing population of ferns and vary the experience through undulating burial mounds.

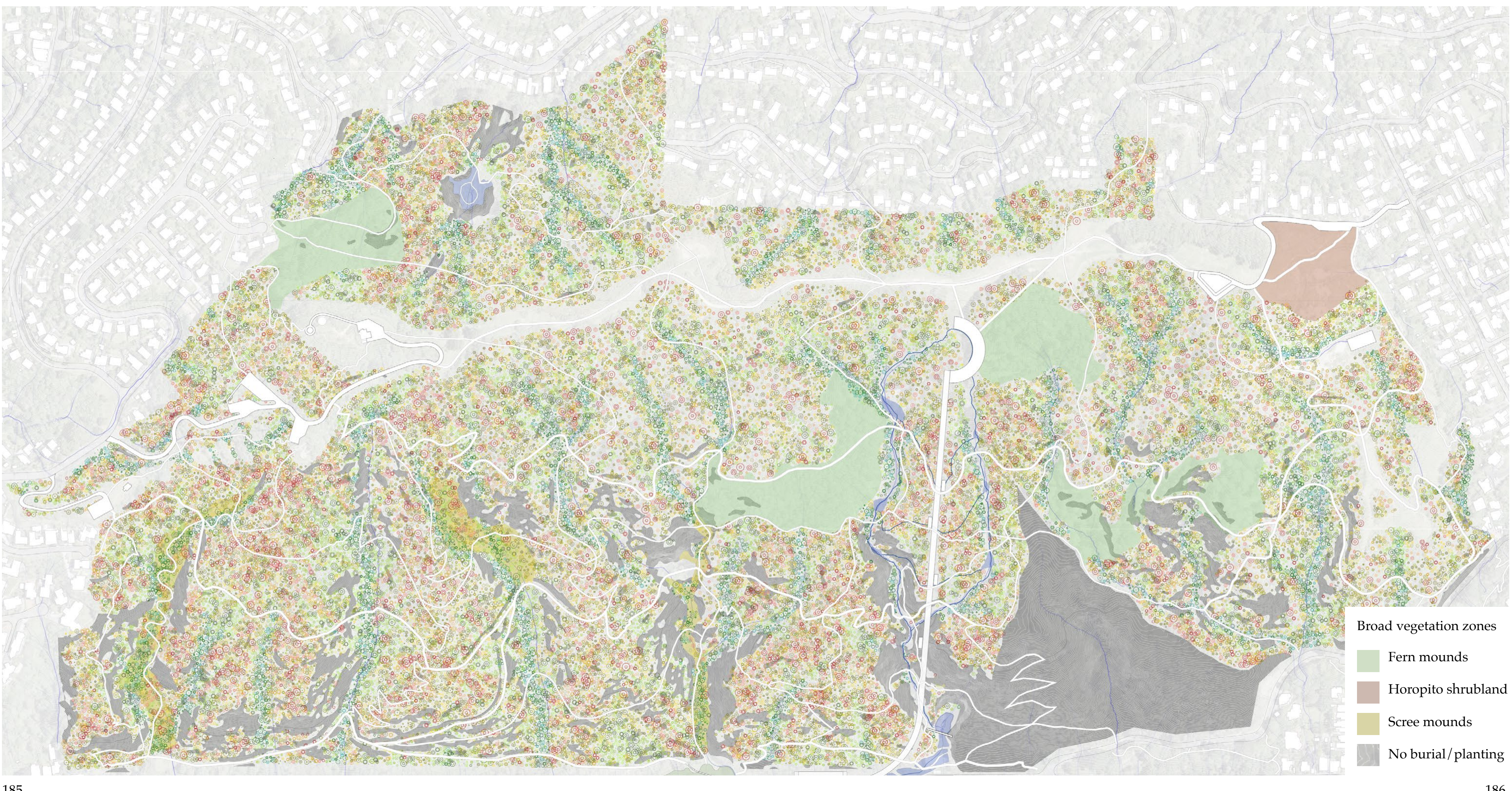




\section{Realm of Potamopyrgus}

Rāhui for Potamopyrgus - Large scale

Investigates how attention to fragile ecology may see areas set aside in cemeteries with ecological considerations.

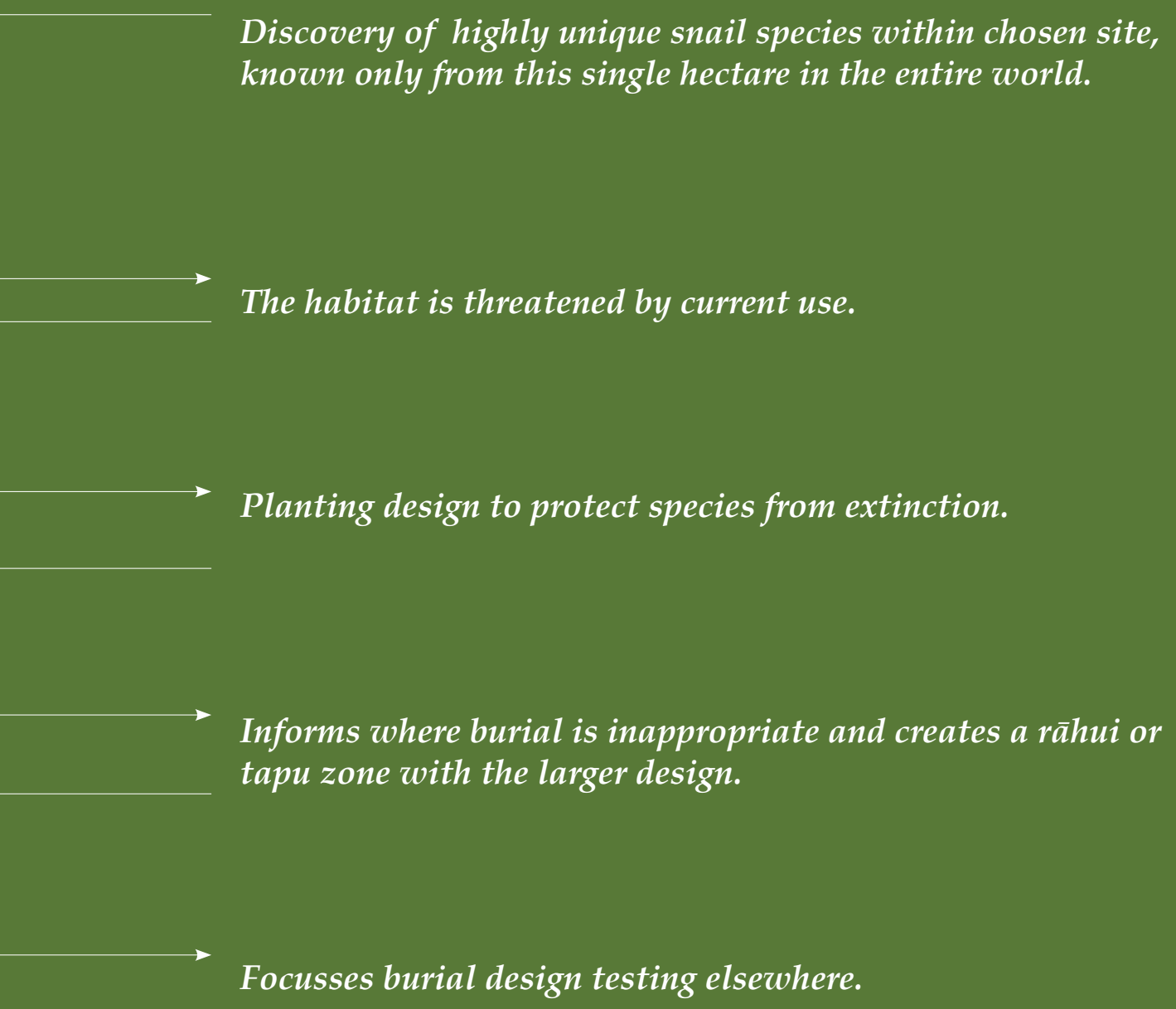




\section{RAHUI FOR POTAMOPYRGUS OPPIDANUS}

\section{Enforced by Ongaonga, Matakoura and Shit-shrub.}

\begin{tabular}{|c|} 
This content is \\
unavailable. Please \\
consult figure list for \\
further details.
\end{tabular}

Fig 41. Potamopyrgus oppidanus Te Ahumairangi Mudsnail

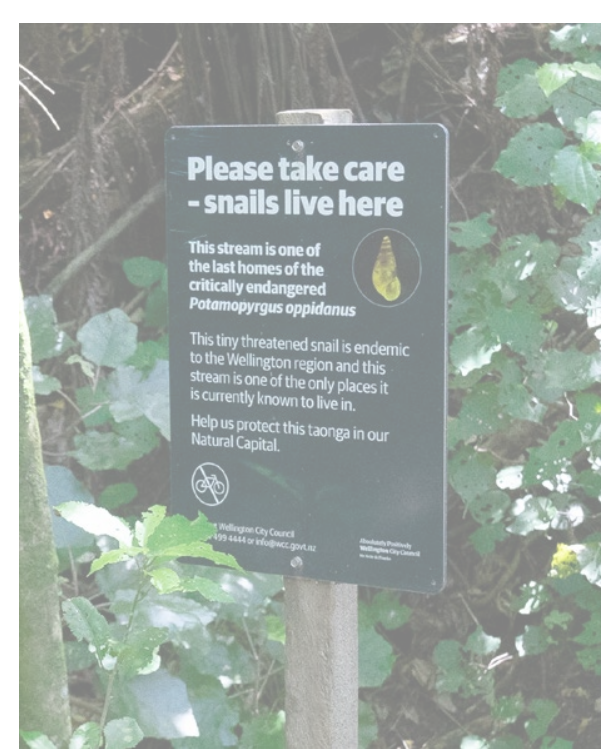

Potamopyrgus oppidanus is confined to an area less than a hectare and is only
known from this single catchment. Its known from this single catchment. Its
habitat consists of stony stream beds, habitat consists of stony stream beds and leaf litter. Vegetation clearan for illegal mountain bike tracks has provided a niche for invasive Tradescantia along the stream. Alongside this, fallen macrocarpa have blocked water flow and leaf litter from entering the stream, which
The species is Nationally Critical and continues to decline. Its relatively small area of habitat, can make protecting this species easier.

A native planting design is proposed that becomes increasingly more unpleasant to humans as one ventures closer.

The first line of defense on the Discaria toumatou. Matakoura has been recorded from early accounts of Wellington's Town Belt It was heavily sprayed in agricultural areas as its thorniness was an impediment to grazing animals. It is now endangered in Wellington, but recently an unknown population was found at Miramar Peninsula and it is deserving of a wider reintroduction to Wellington. It provides habitat for lizards and nesting birds.

The second line of defense is Coprosma foetidissima colloquially know as shit-shrub on the account of its pungent smell when crushed or cut. Any illegal track clearance would leave the nostrils burning. It provides habitat for the native stag beetle.

Ongaonga is a stinging nettle which is found through le Ahumairangi. Damp and shady areas lower in the catchment are planted to encapsulate the stream with this stinging native plant. It is also the main food

. kahukura. The stream edges are replanted with mahoe whose leaves appear to be a favoured food of the mudsnail.

Existing walking tracks which cut across the habitat have been rerouted now two small areas of boardwalk cross at the top and bottom of the catchment, where the impact of track maintenance and walkers is reduced.
Current

Disturbed Riparian Area

Regenerating Native Forest

Coniferous Forest

Large Cupressus macrocarpa

$\square$ Old kainga

Existing Tracks

Water Catchment

Proposed

Mahoe - Melicytus ramiflorus

Ongaonga - Urtica ferox

Shit-shrub - Coprosma foetidissima

Matakoura - Discaria toumatou

- Boardwalk

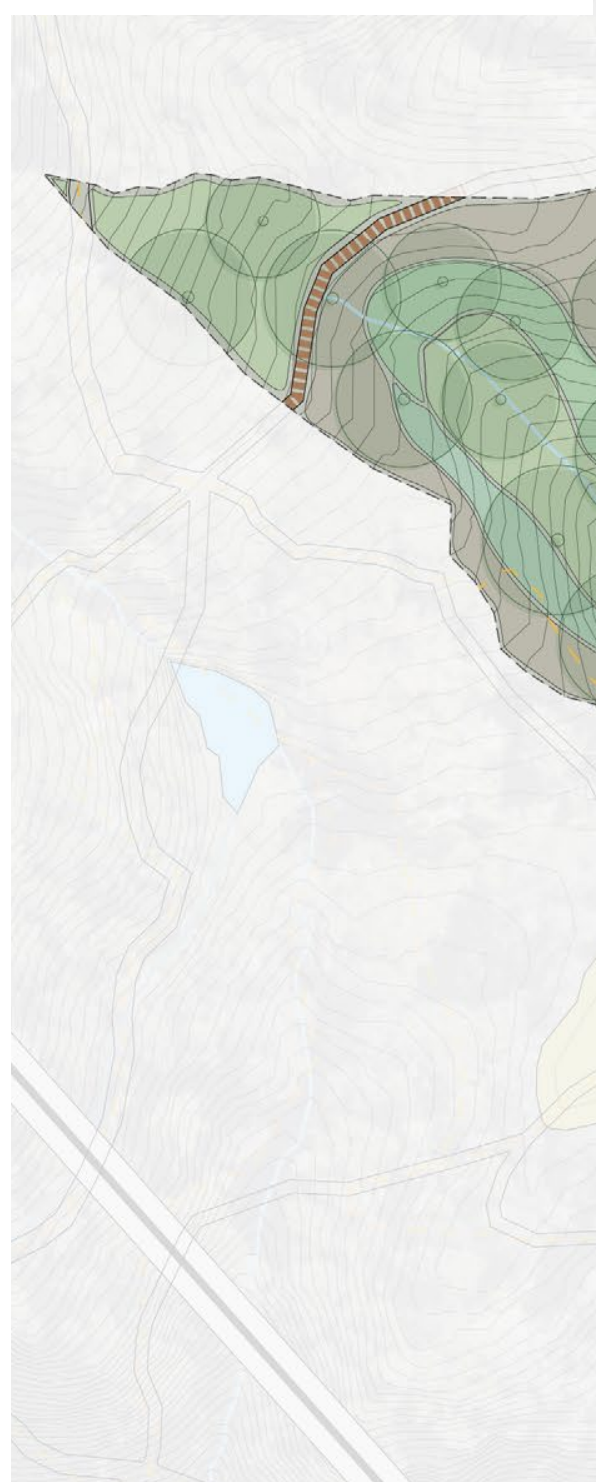




\section{Ridgeline Design}

A floristic connector route - Wide scale

Investigates the current experience and proposes alterations to recreation and procession along a flower-picking ridgetop route.

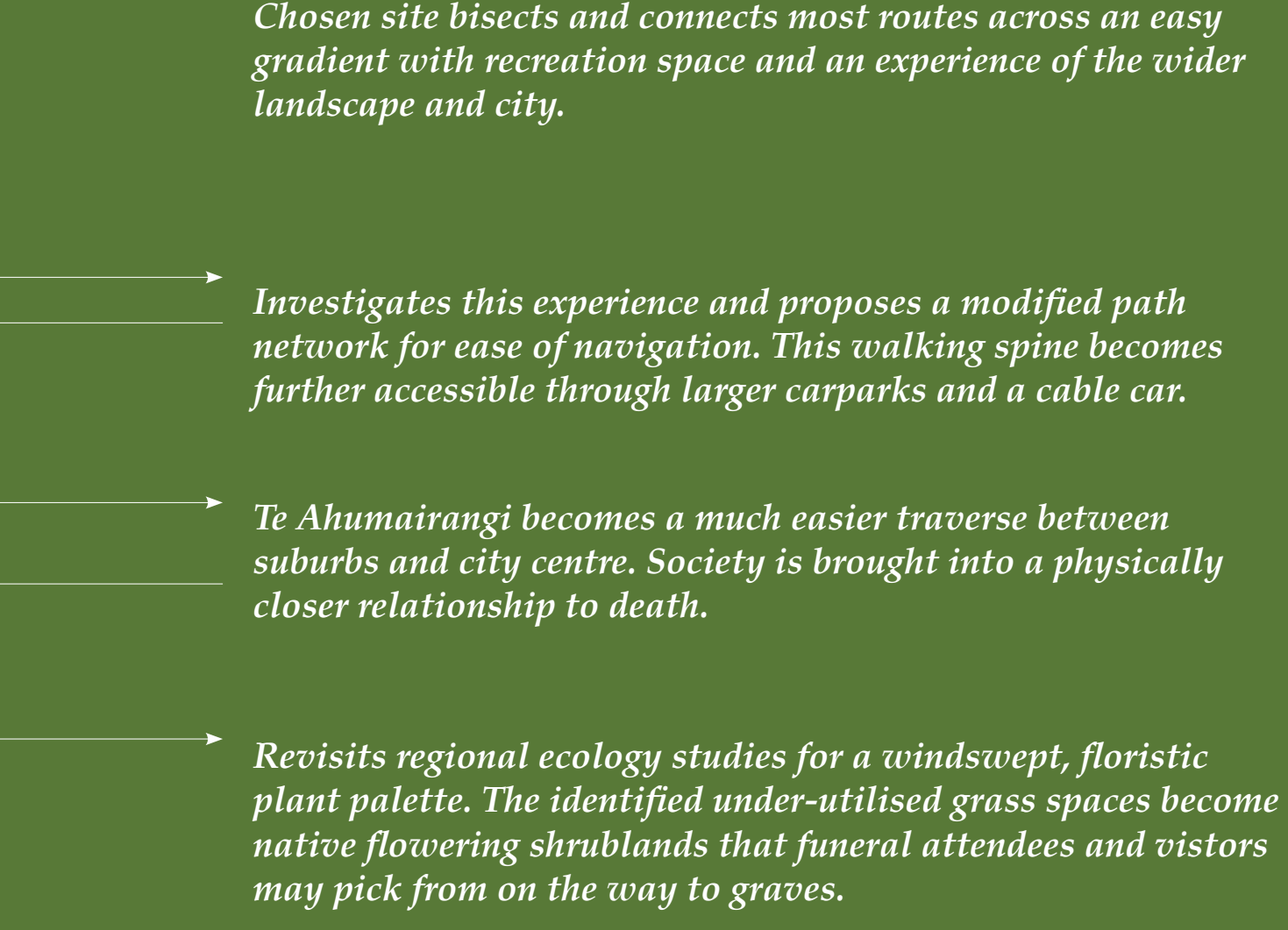

$\rightarrow$ Revisits regional ecology studies for a windswept, floristic plant palette. The identified under-utilised grass spaces become native flowering shrublands that funeral attendees and vistors may pick from on the way to graves. 


\section{Long Section Through the Ridgeline}
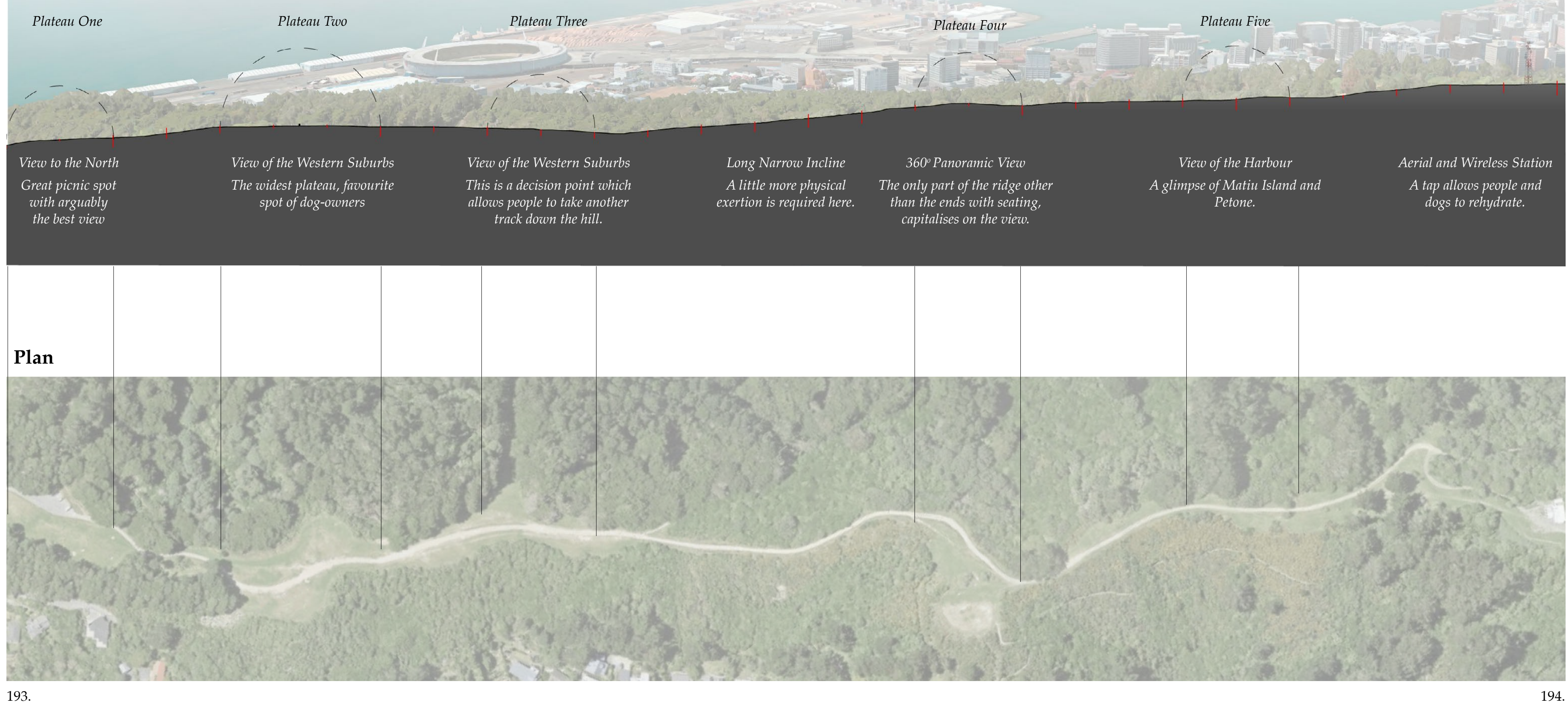


\section{Current Experience of the Ridgeline}
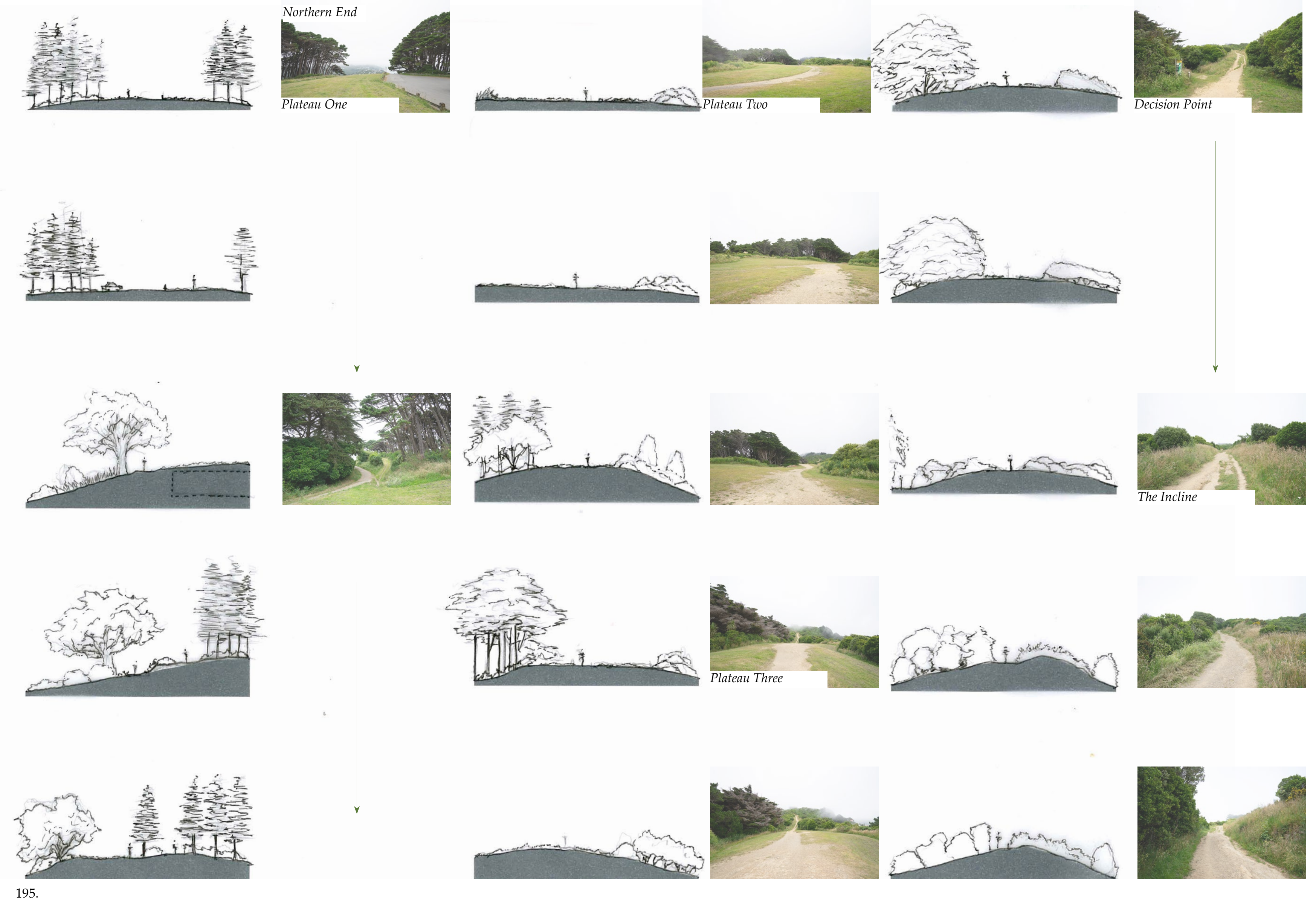


\section{Current Experience of the Ridgeline}
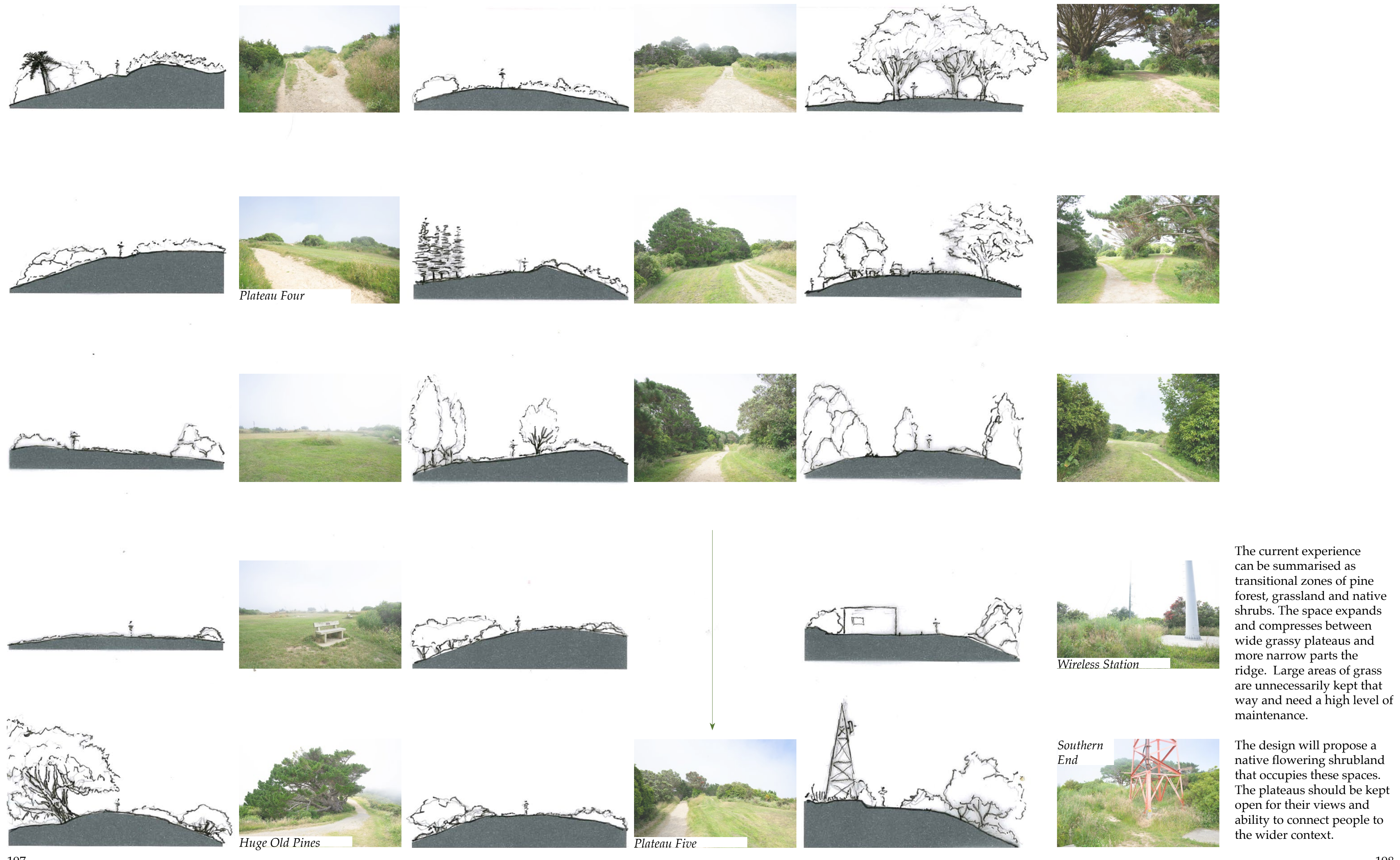


\section{Ridgetop Plant Selection}

derived from visited ridgetop ecologies in the region

1. Astelia fragrans Kaiwharawhara

2. Clematis afoliata Leafless Clematis

3. Clematis forsteri

Forster's Clematis

4. Coprosma foetidisima Stinkwood

5. Coprosma crassifolia Shrubby Coprosma

6. Cordyline australis Ti Kouka

7. Cortaderia fulvida Toetoe

8. Discaria toumatou Matakoura

9. Griselinia littoralis Papaumu

10. Hebe parviflora Tree Hebe

11. Hibiscus trionum Puarangi

12. Metrosideros perforata Akatea

13. Microsorum pustulatum Hound's Tongue Fern

14. Muehlenbeckia complexa Pohuehue

15. Myrsine australis Matipo
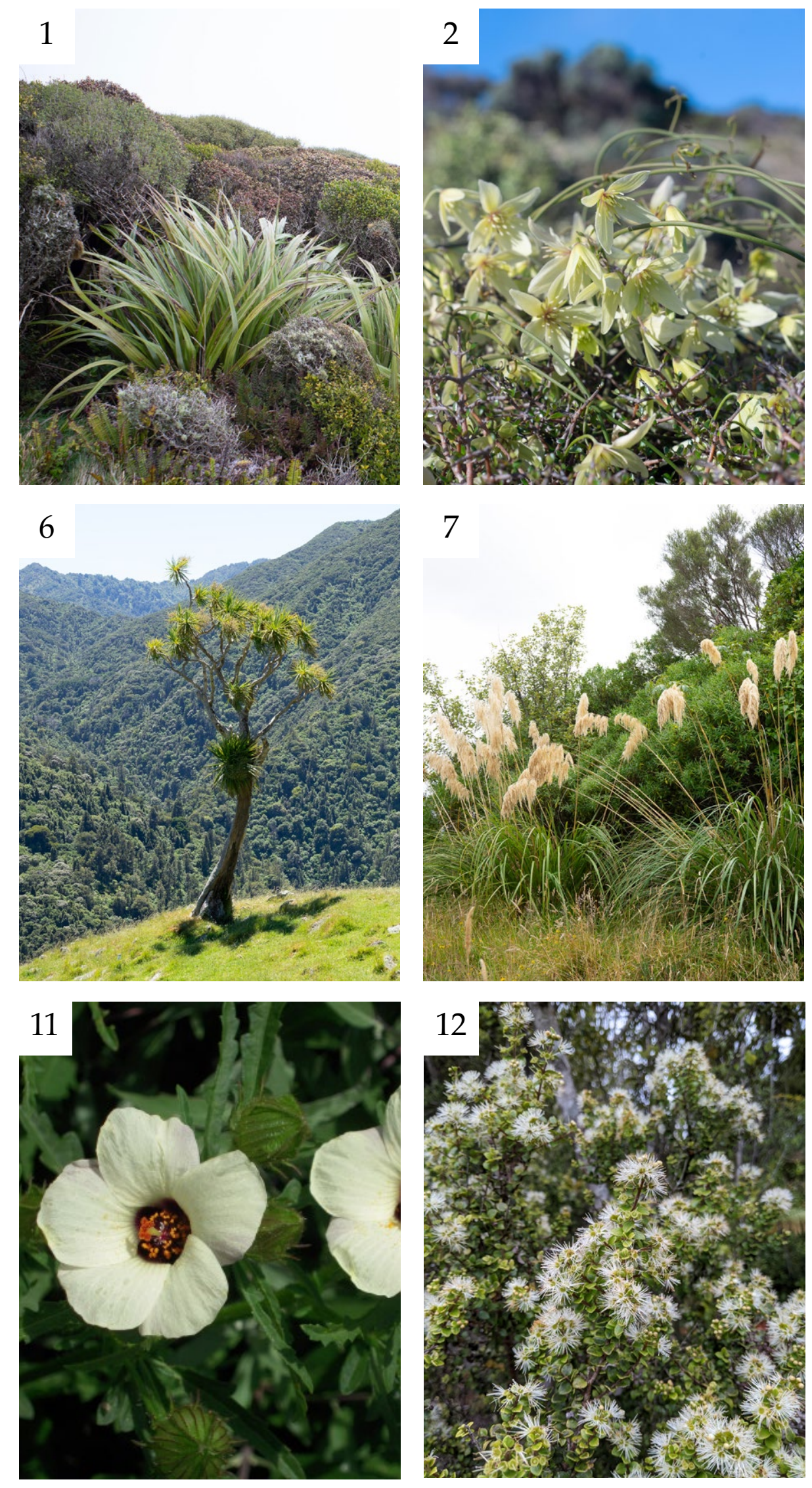
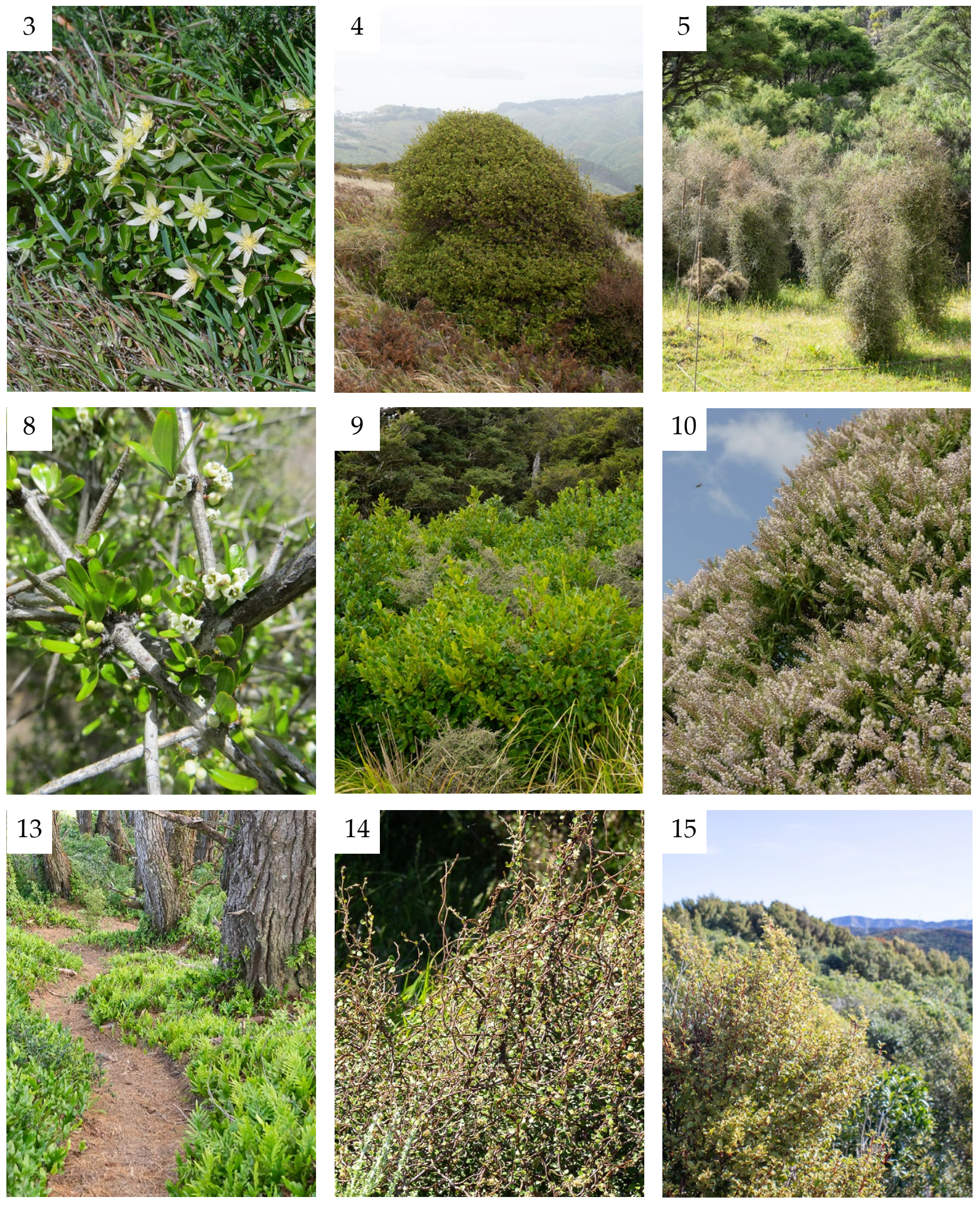
6. Phormium cookianium Wharariki

17. Pseudowintera colorata Horopito

18. Raukaua anomalus Raukawa

19. Rubus squarrosus

20. Sophora molloyi

Cook Strait Kowhai

21. Weinmannia racemos Kamahi
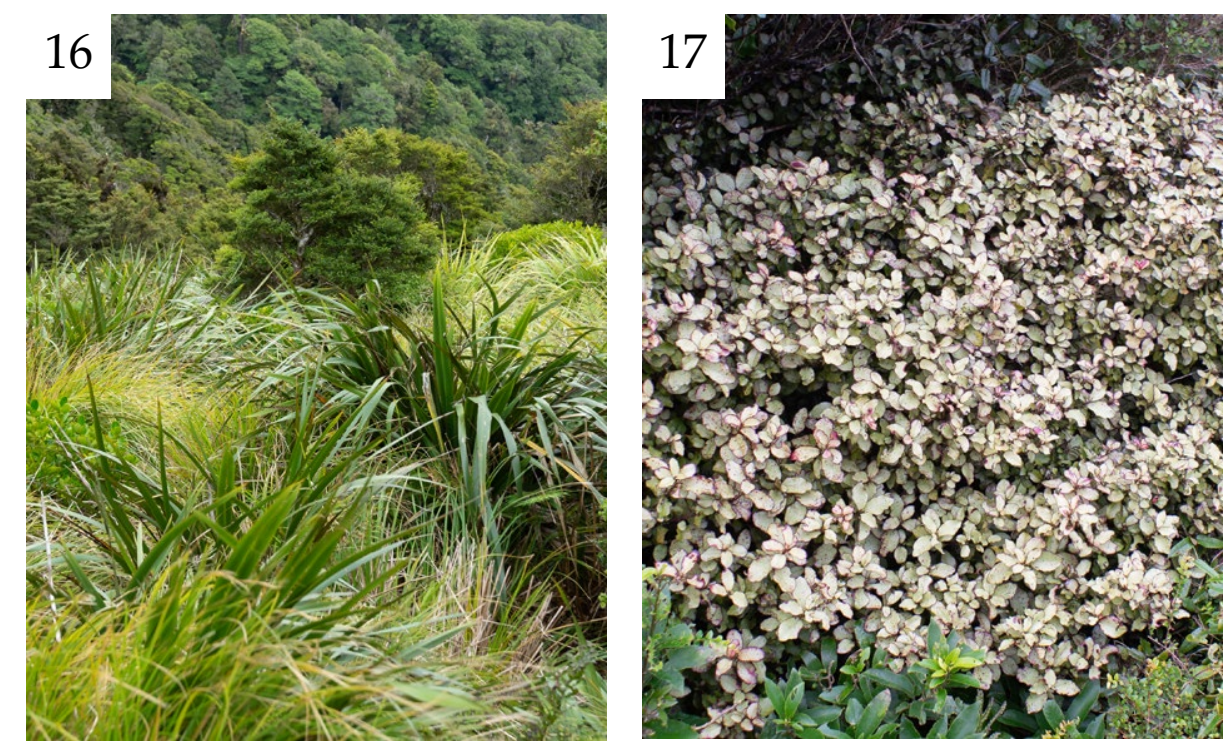

18

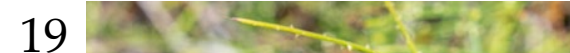
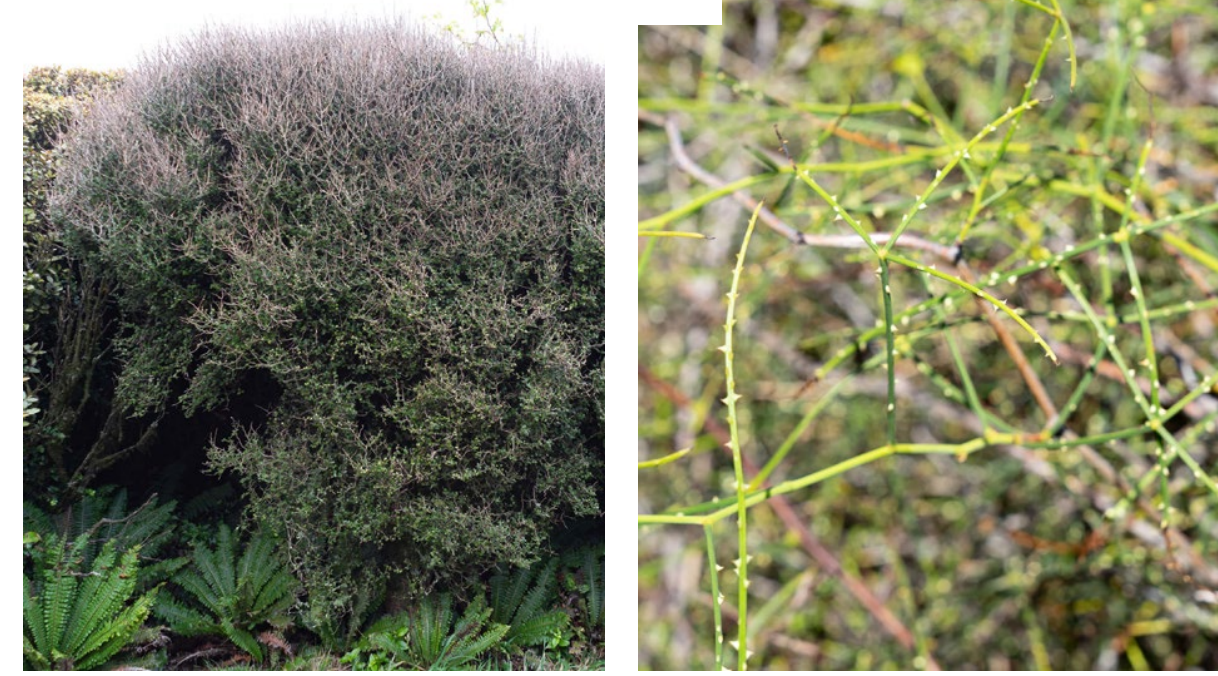

20

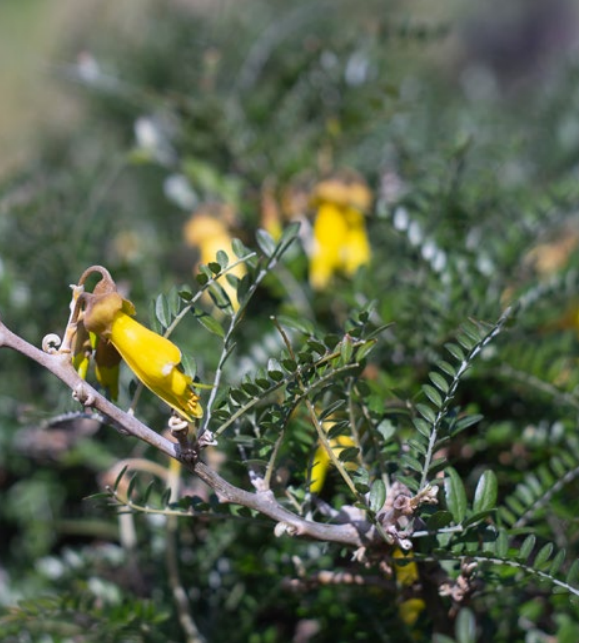

21

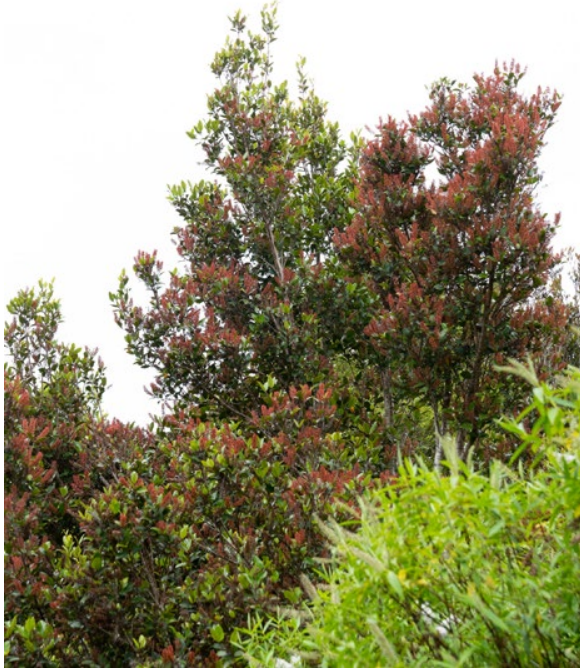

Designing the

Ridgeline 
Pathway Network

\section{Paths and Decisions}

\section{Existing Path Network}
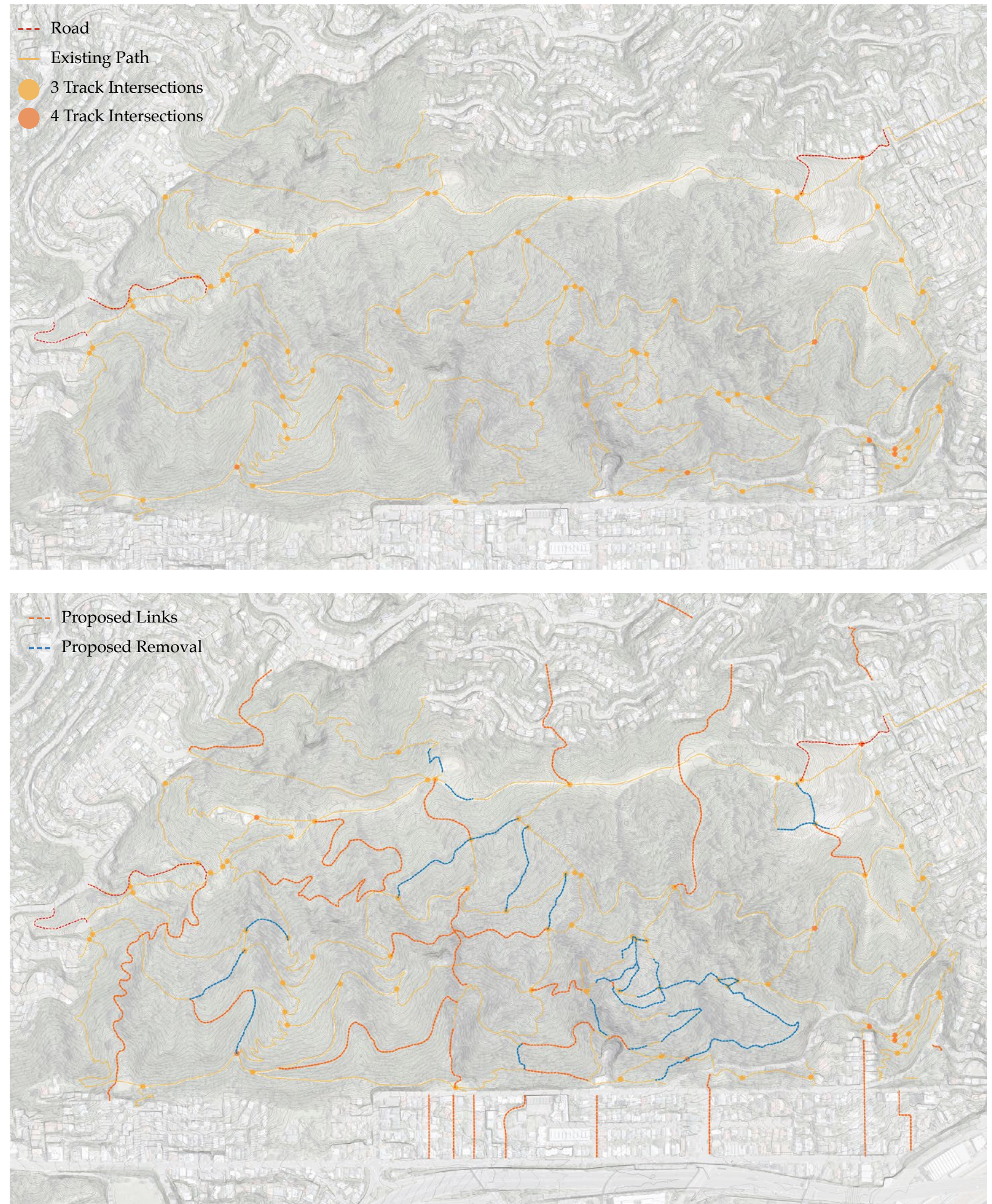

Proposed Path Network
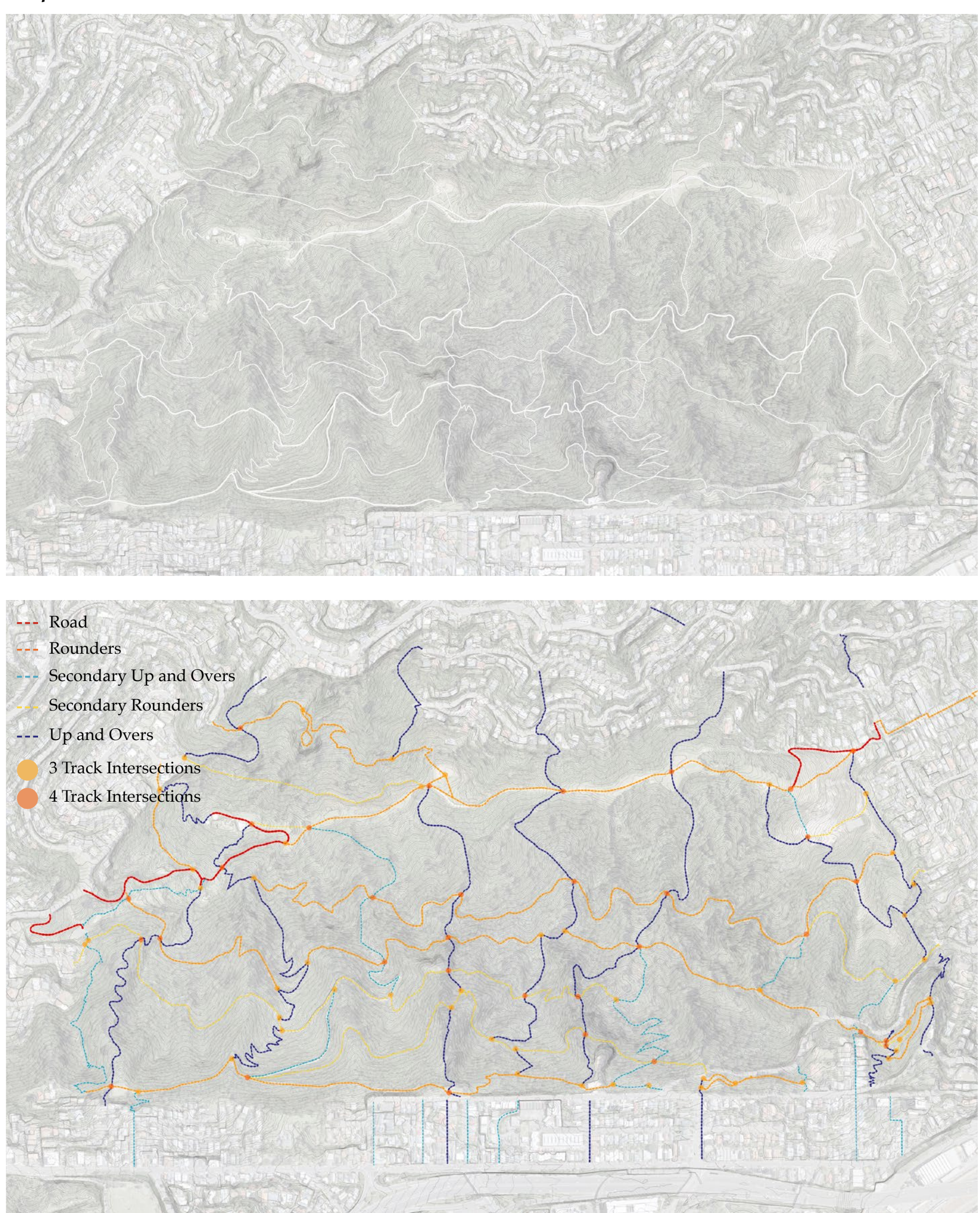


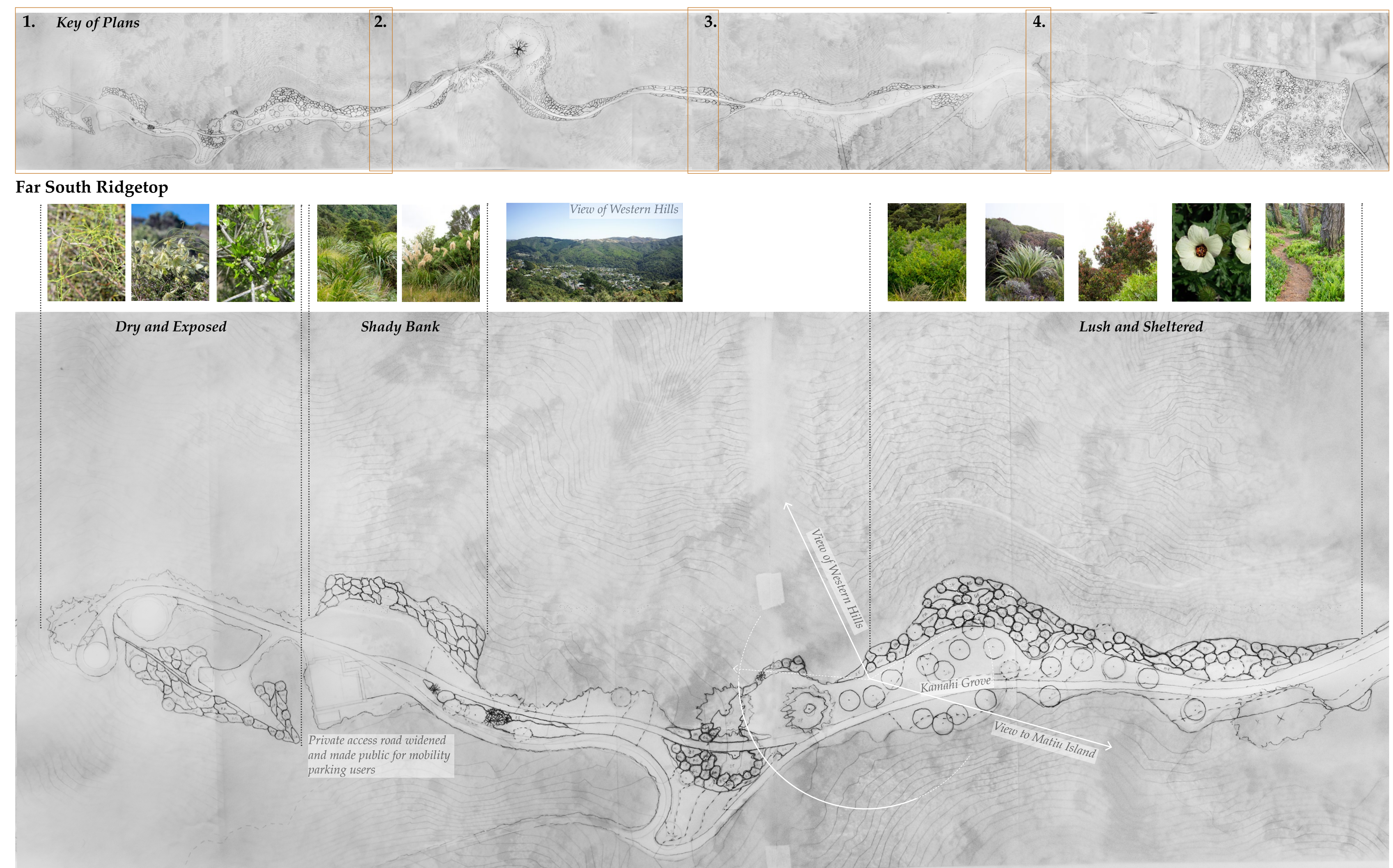


Matipo Grove

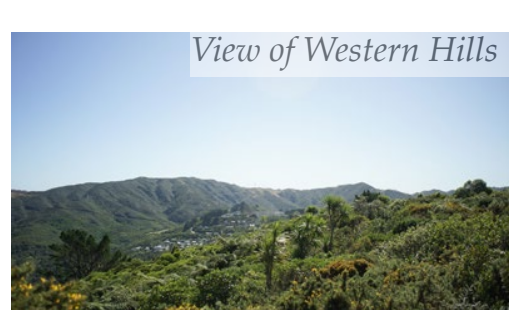

(2.)
Exposed Shrubland

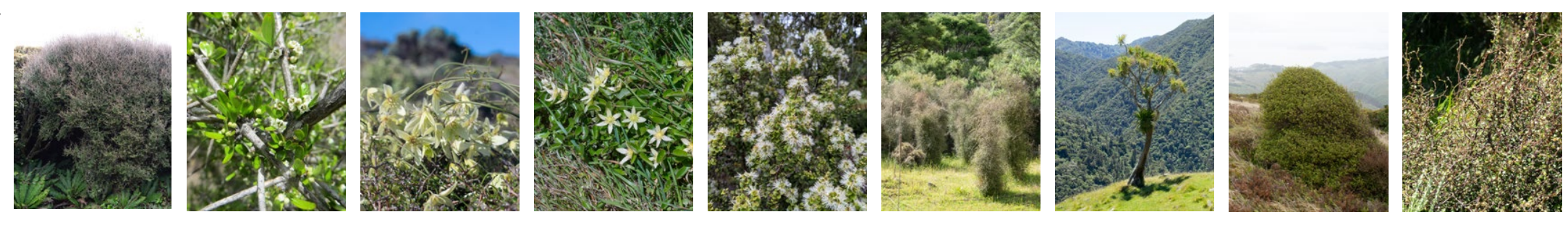

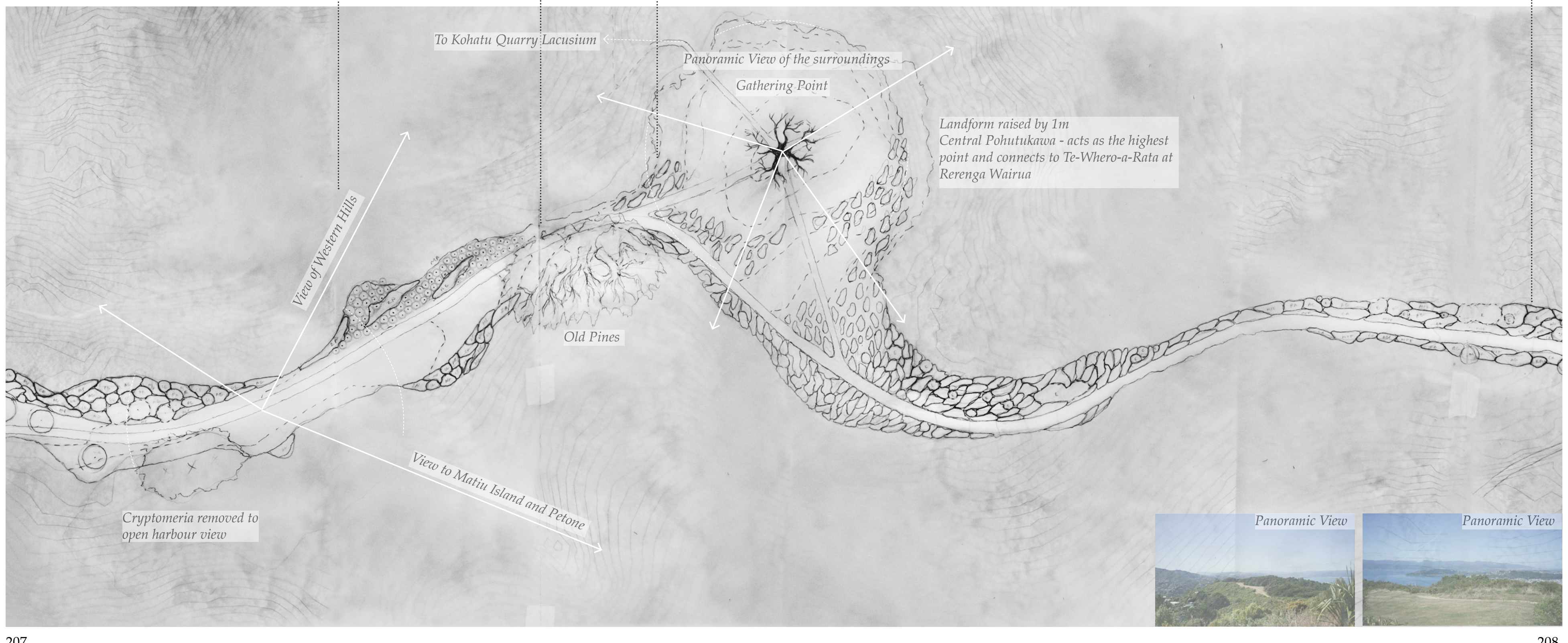




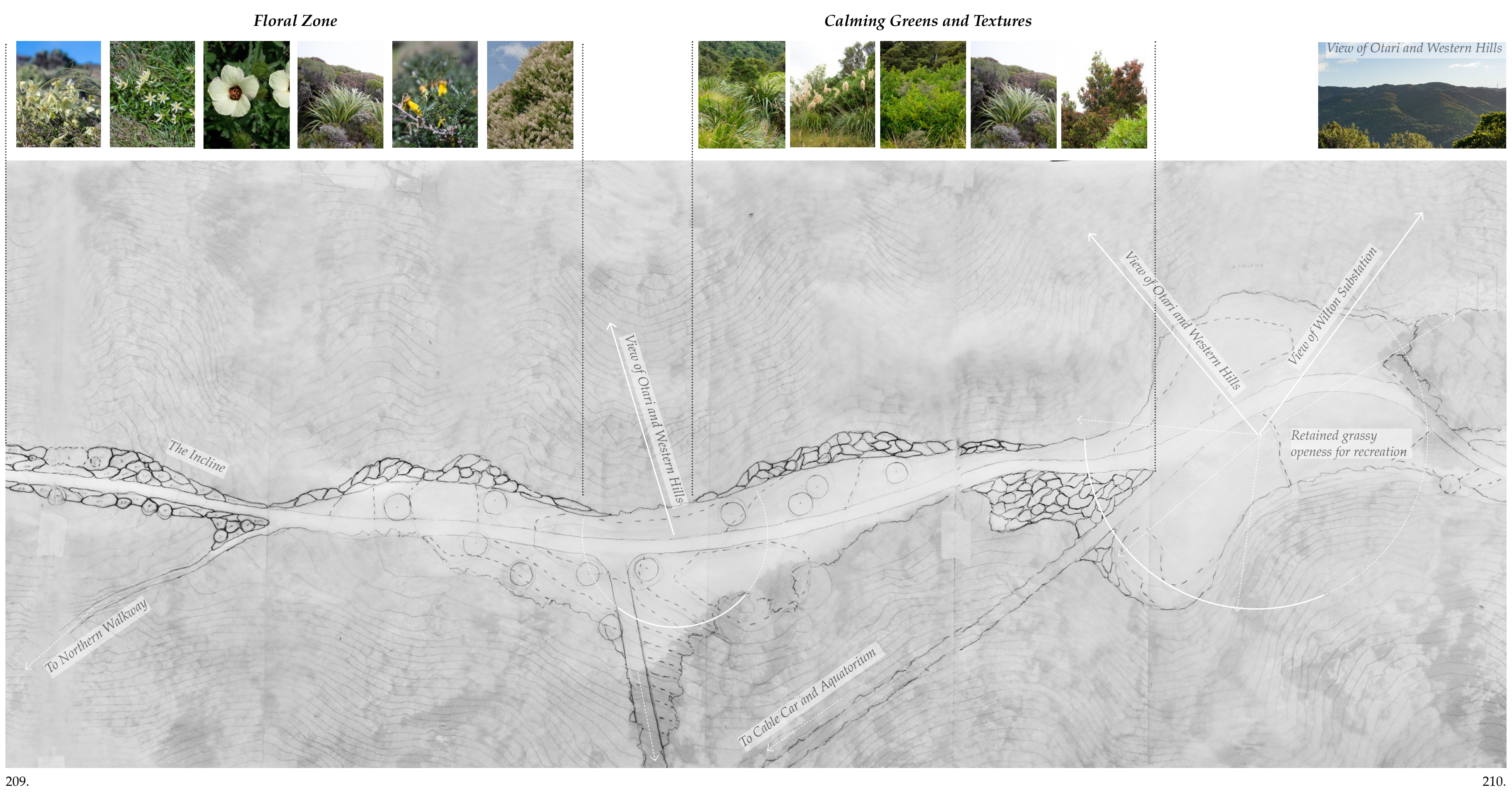


Horopito Shrubland Burial Zone

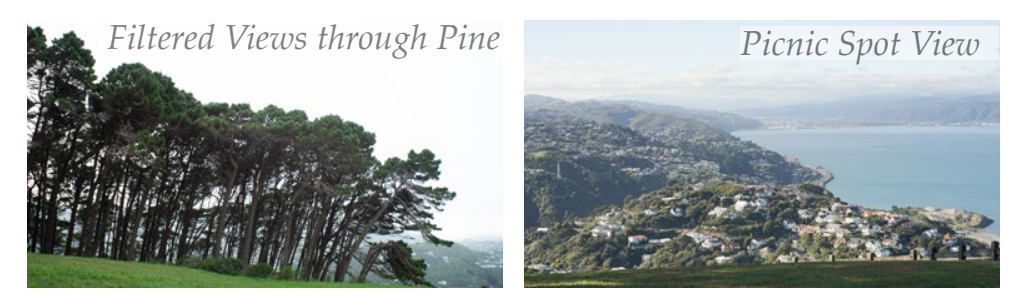

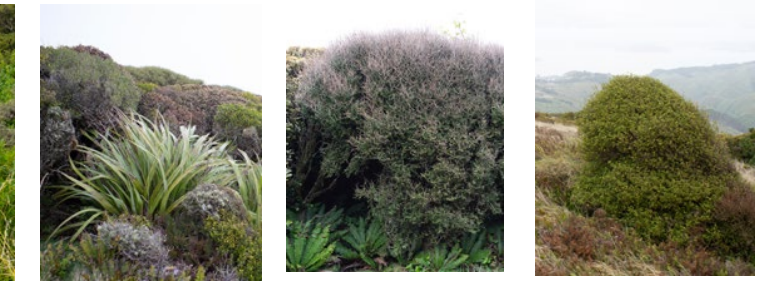

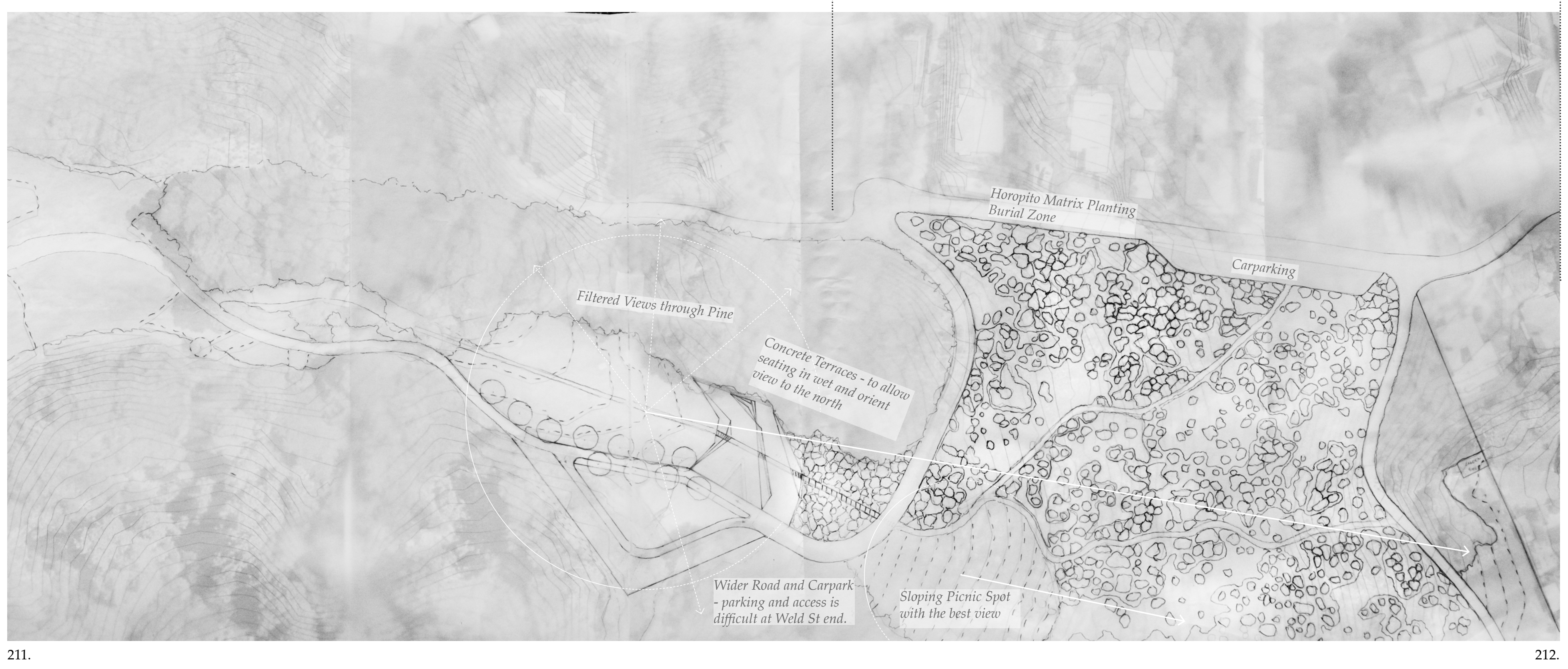




\section{Aquatorium - Crematorium - Masterplan}

Visitor centre - Large / Intermediate scale

An interconnected series of buildings, transport and waterways addressing access and connectivity within the cemetery.

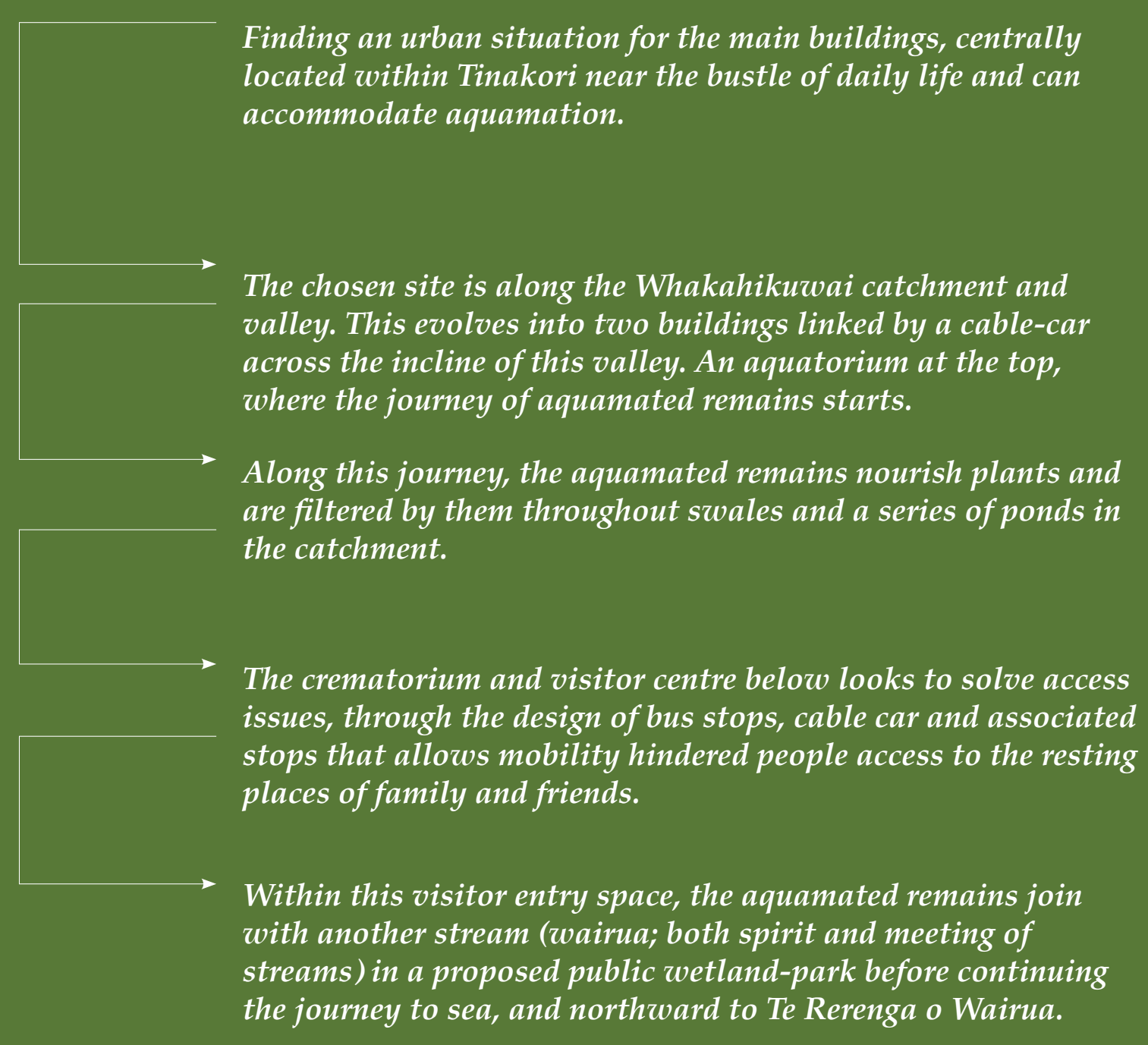




\section{Gulbenkian Garden}

\section{Watery Landscapes and Architecture}

\section{Year -1969}

City - Lisbon, Portugal

Landscape Architect/s - Goncalo Ribeiro Telles and António Viana Barreto

Architect/s - Ruy Jervis d'Athouguia, Pedro Cid and Alberto Pessoa

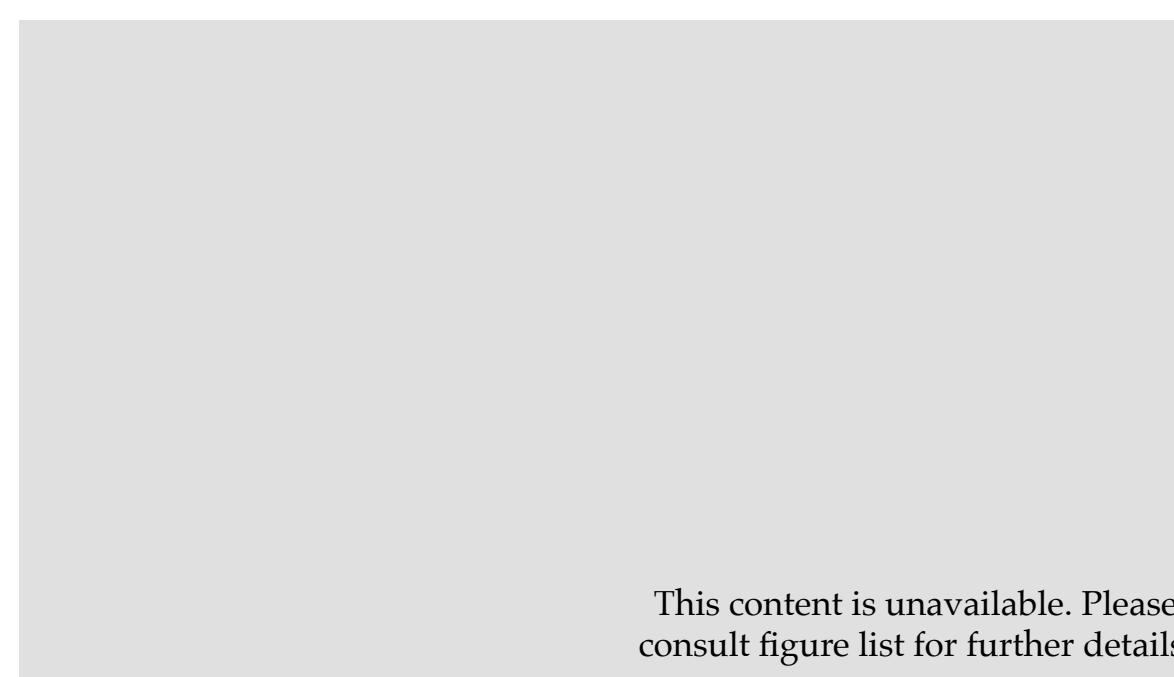

consult figure list for further details.

The landscape architects enlarged

the existing lake and brought three

streams together. This created an

interconnection between elements of

the park and structure the vegetation

and experience into a central focus

from which everything is generated.
This content is unavailable. Please consult figure list for further details.
The streams to the east and west increased the depth of the lake and established a stronger bond between architecture and landscape. By increasing the area of water, the dynamism and depth. The garden now offered greater complexity and diversity as well as greater ecological variety.

This relationship between

architecture and watery landscape is particularly useful as a preceden for the design of aquatoria, a building that could involve the watery remains of humans into the landscape instead of flushing this benign liquid into the wastewater 

$\begin{array}{ll}\text { The initial design centred on using } & \text { This particular path, needed the cable } \\ \text { the large premier house (mansion for } & \text { car to tunneled across large areas and }\end{array}$ prime ministers) parcel of land as the bridged in others.

rest of the urban realm constrained

the needed angle for a cable car.

The other element of the design

included several green space bridges that cover the sunken motorway and

This cable car would act as an accessibility route for the elderly and anyone wishing to avoid the steep hill. From the multiple cable car stops, mourners could visit the graves of their loved ones along contour-paths. The cable car would also have a separate car that would act as a hearse, allowing a body to easily transported up the hill to the grave site. across the bisected halves of the city.

This particular choice of site was abandoned as further design revealed greater integration of cable car public space and access were possible elsewhere.

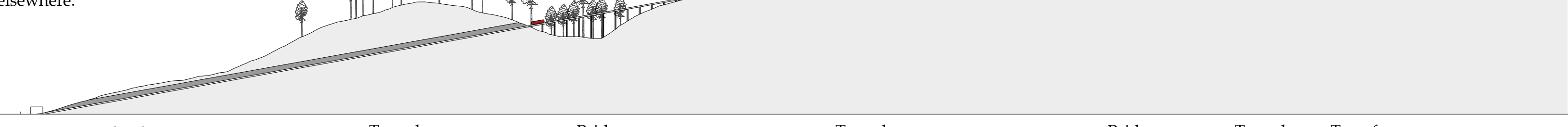

Premier House land

Tunnel

Bridge

Tunnel

Bridge

Tunnel Top of car

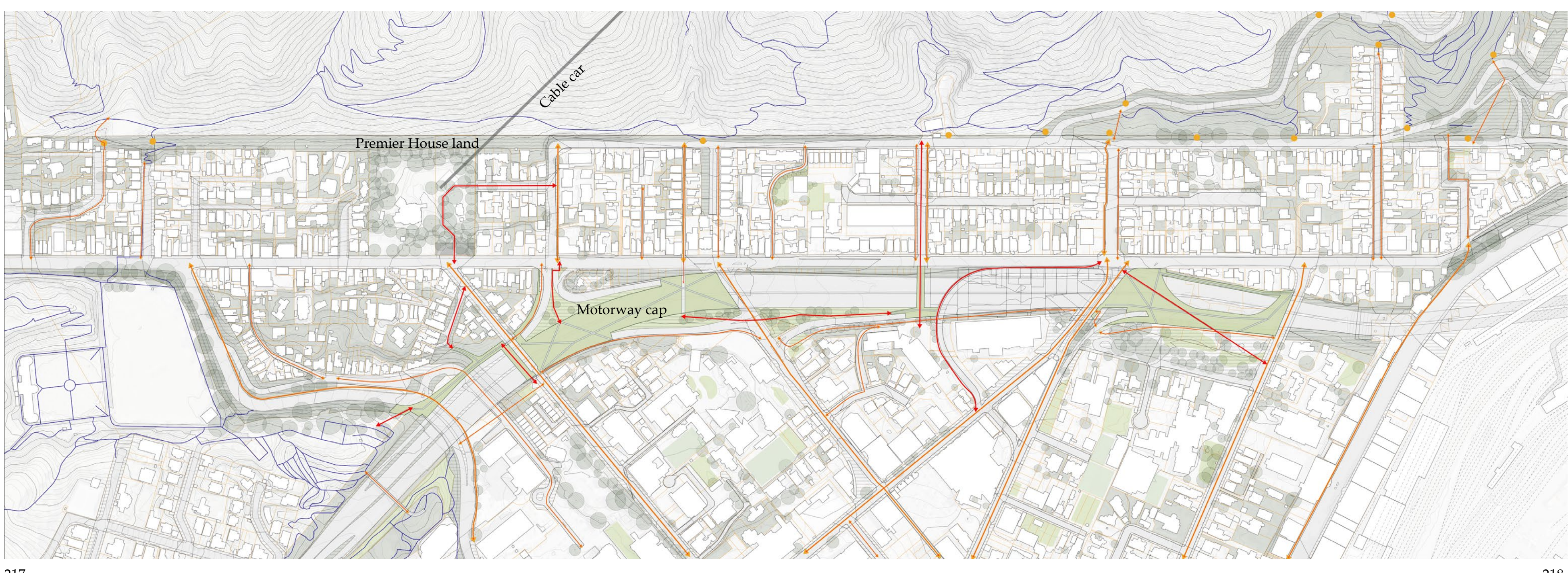


Flood Prone - Little George St

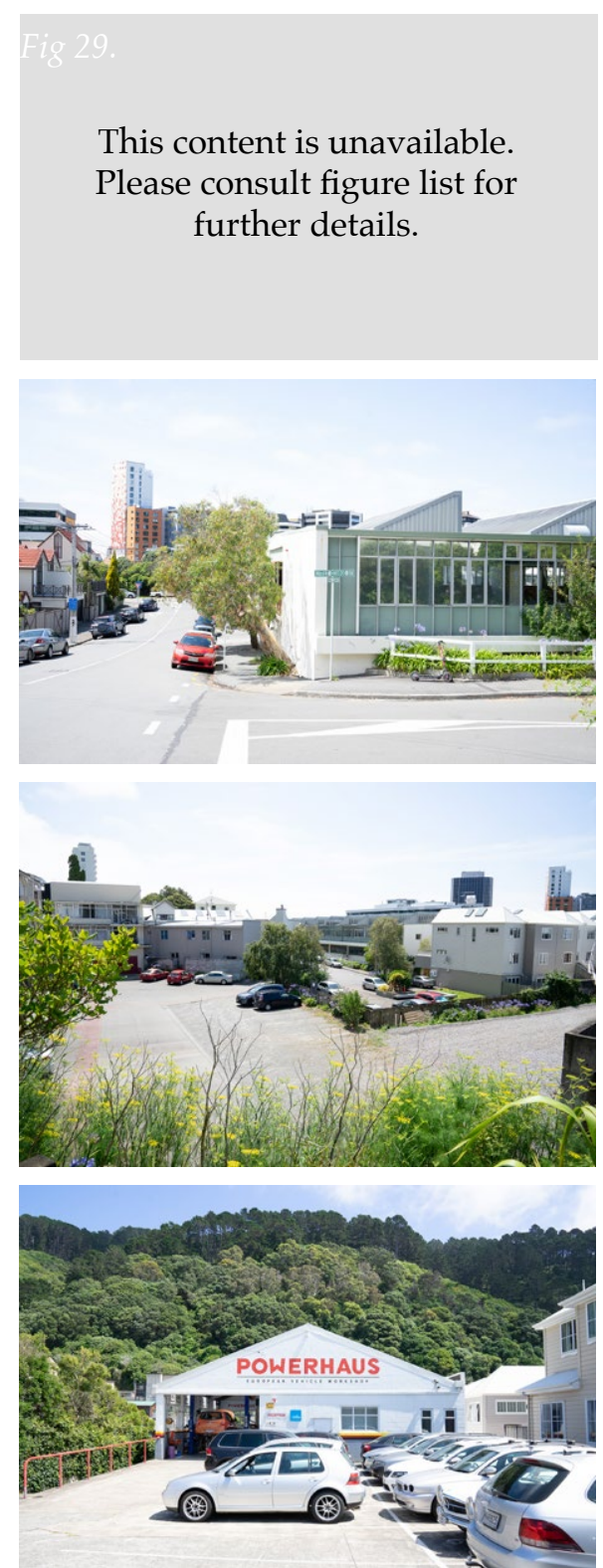

Two of the larger affected buildings are suggested as high-quality densified housing for the owners of affected properties.

The Potters association is suggested to merge and have residency within the cemetery visitor centre. The crematorium within this can help heat the firing kilns and create a more sustainable cremation process.

The potters may also wish to sell handmade urns for cremated and aquamated remains.
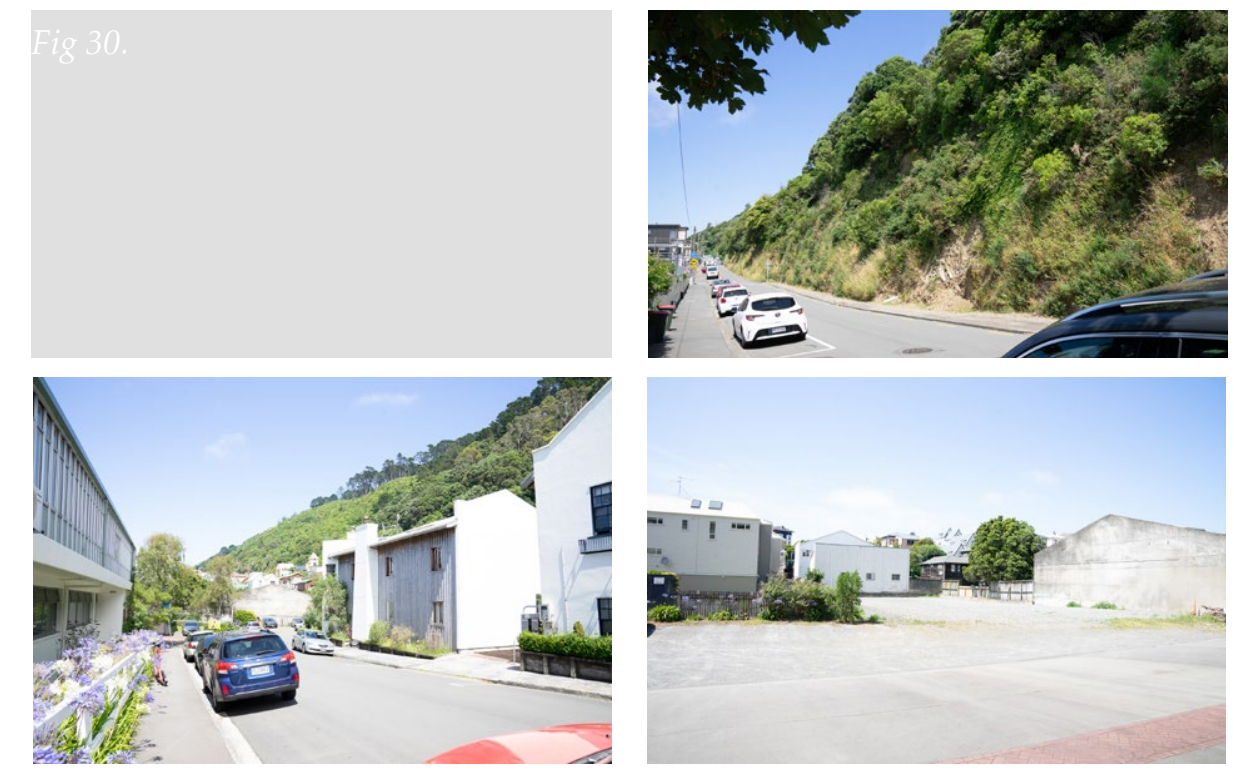

This historically flood prone area became important in the design of the Aquatorium. The landscape is Tiakiwai stream used to run. It's landmass makes for a more viable
option than Premier House land.
It also gives a much larger area for
water to collect from Aquamation

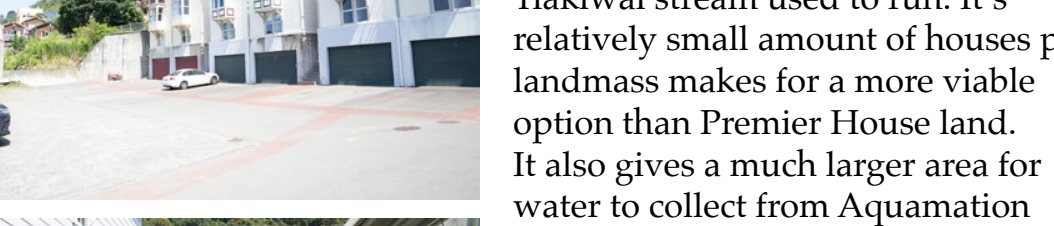
landmass makes for a more viable
option than Premier House land.
It also gives a much larger area for
water to collect from Aquamation landmass makes for a more viable
option than Premier House land.
It also gives a much larger area for
water to collect from Aquamation landmass makes for a more viable
option than Premier House land.
It also gives a much larger area for
water to collect from Aquamation (1)

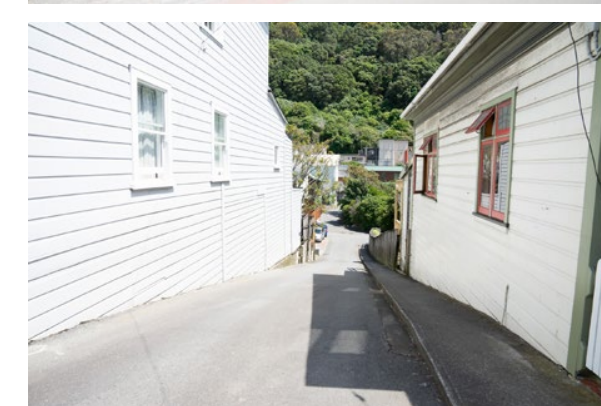
and create an urban wetland park.

Diagram of proposed site
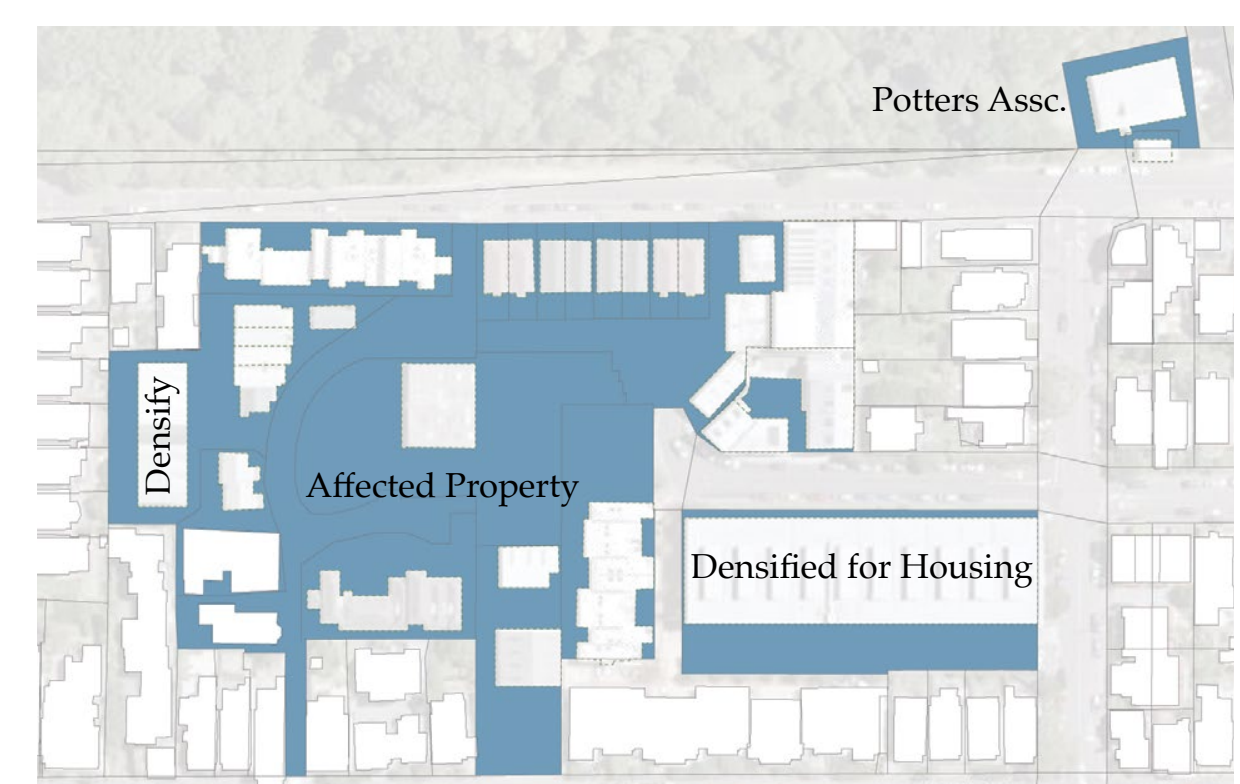

\section{Developing Design of the Aquatorium and Cable Car}

Whakahikuwai stream-Before Whakahikuwai stream-After

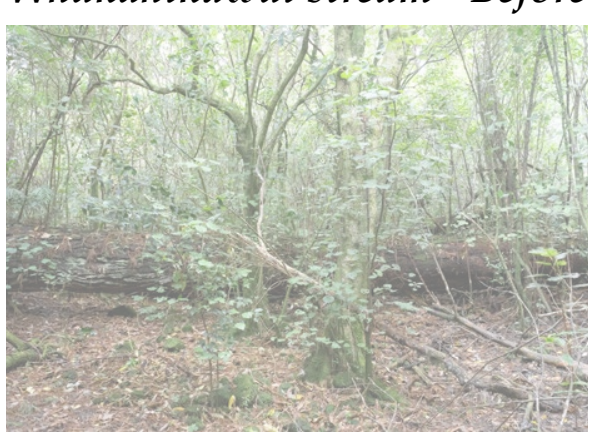

An increase in water in the landscape bringing a greater diversity of epiphytes and plant life.

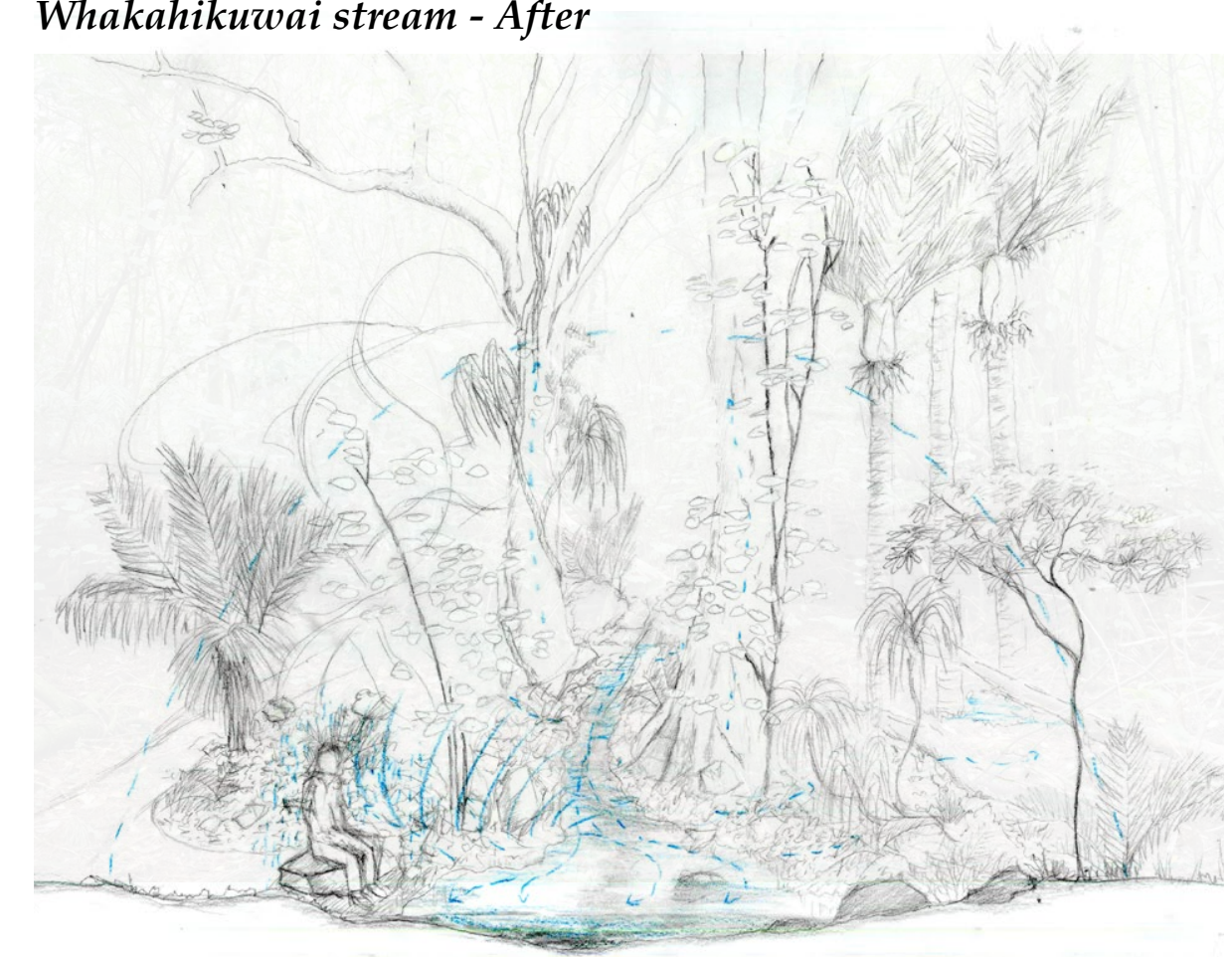

The crematorium and visitor centre nestles into the slopes of $\mathrm{Te}$ Ahumairangi. The botton foor glass is the main atrium, from here the next level is a space for funerals. Above this an open rooftop provides a large space from the propagation in an outdoor native plant nursery. These trees can then be taken on the cable car to plant atop the deceased. A

crematorium sits below the relocated potters association. Atop allow this is the cable car, accessible by the central elevator. The cable car no longer tunnels through the hill, instead two small trenches and bridges are all that is needed in construction.

\section{Journey of remains from ridge to basin.}

\section{Aquatorium}
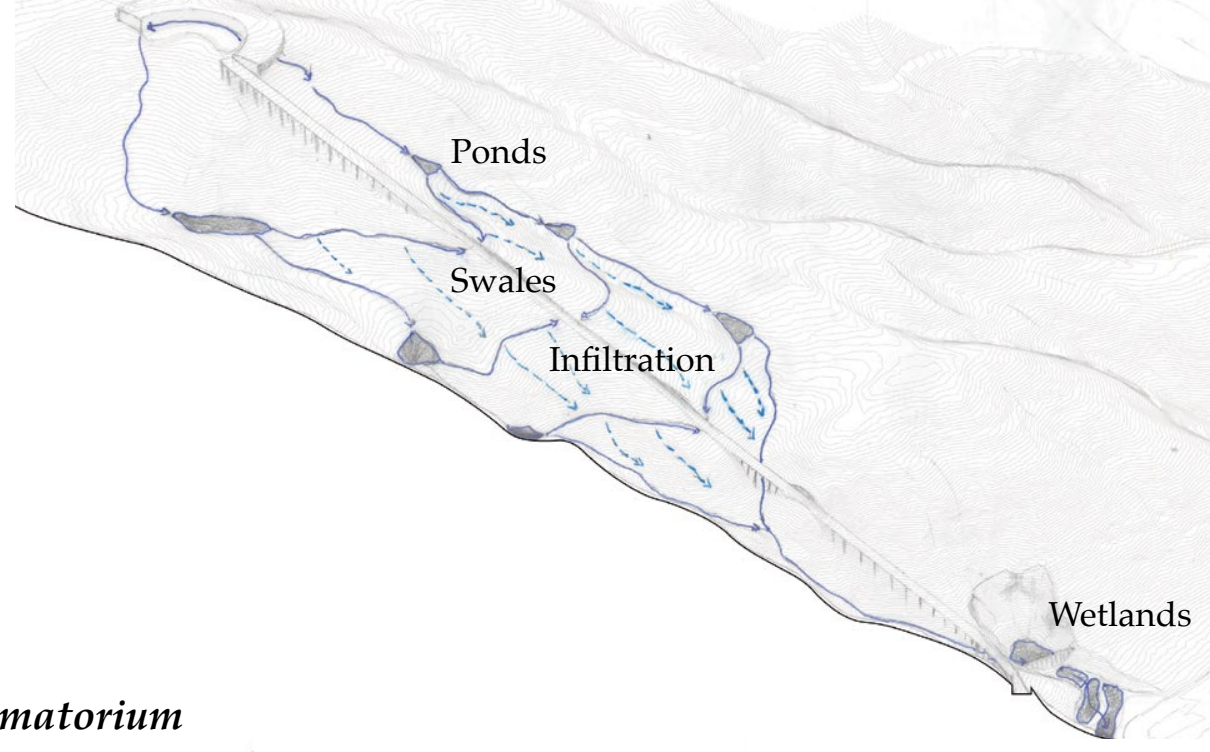

Section through wetland and crematorium

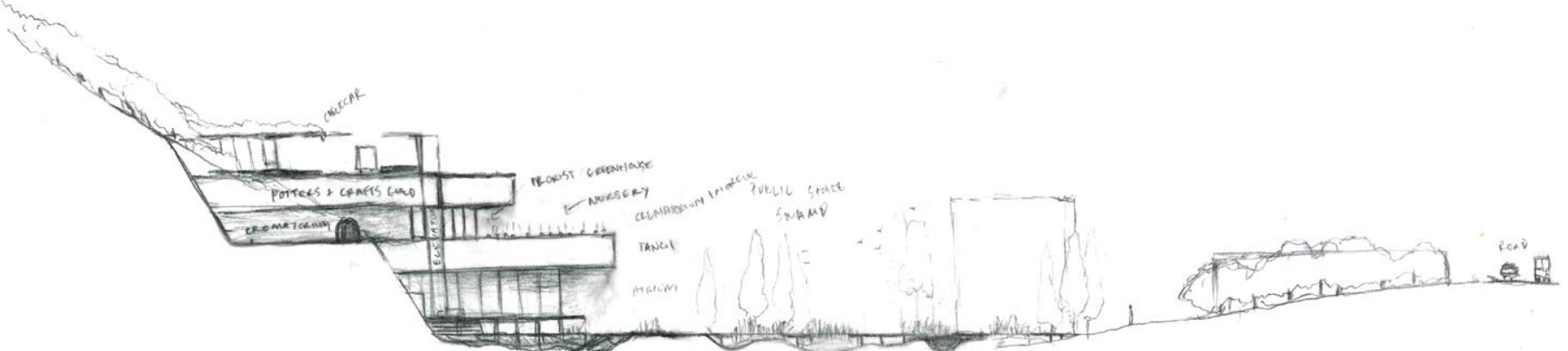




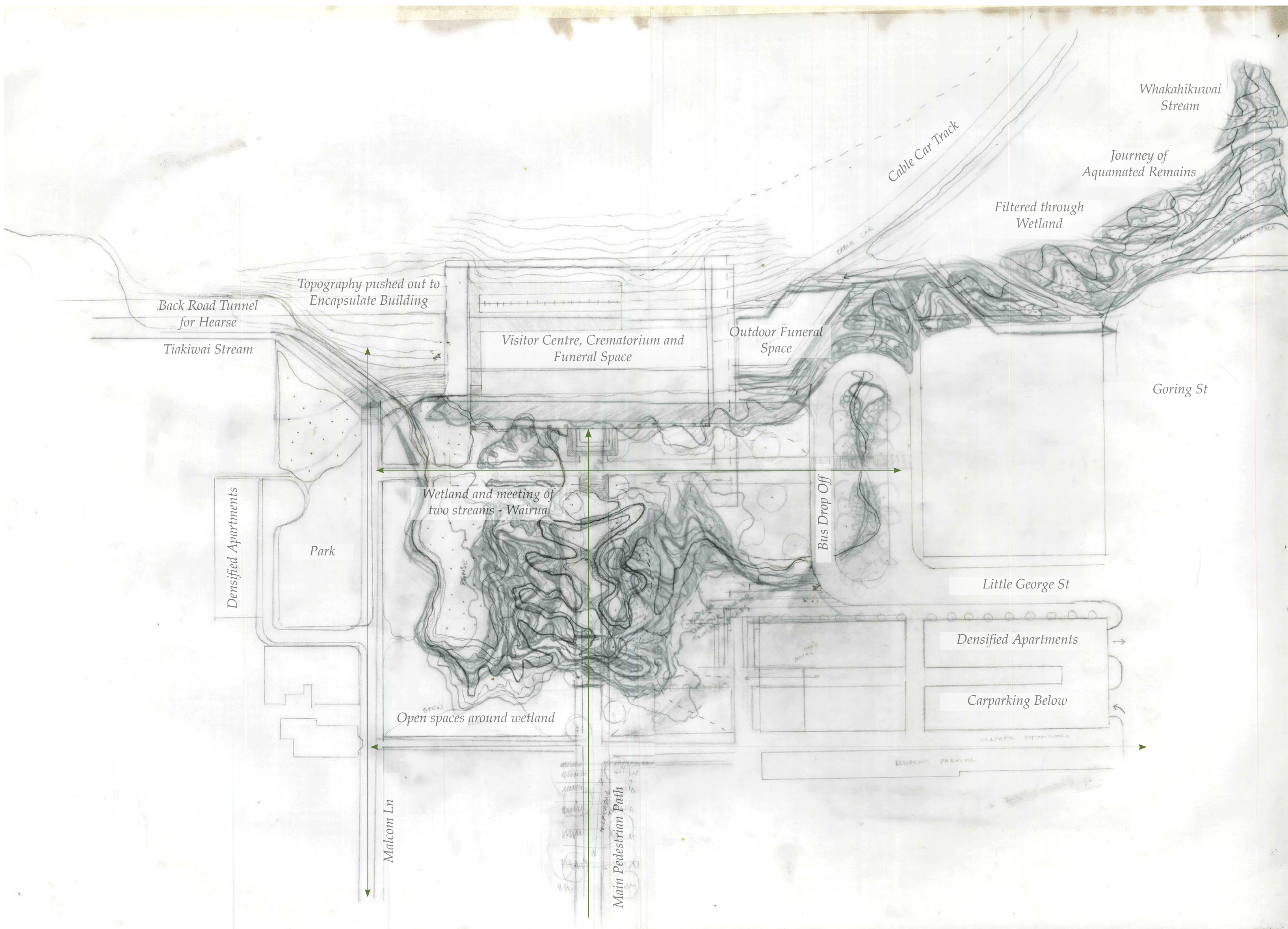

The design aims to create clearer access from Tinakori Road, to allow more easily.

From the excavation for the wetland, the topography of the hill is pushed out to encapsulate the building. This also forms the new daylighted edge of Tiakiwai stream which once ran through here.

Aquamated remains that move through Whakahikuwai catchments are directed into a series of terraced wetlands that step down and treat the water before reaching the larger wetland park space. The two streams come into confluence. Wairua - two streams and also meaning spirits.

The main pathway which crosses this wetland breaks away into a board walk crossing small, dry islands and surrounded by kahikatea.

From here members of the public and funeral goers can take the cable car up the steep hill. Making Te

Ahumairangi much more accessible

to everyone. It also provides mean

of transporting the deceased up to section where they will be buried. 
Masterplan

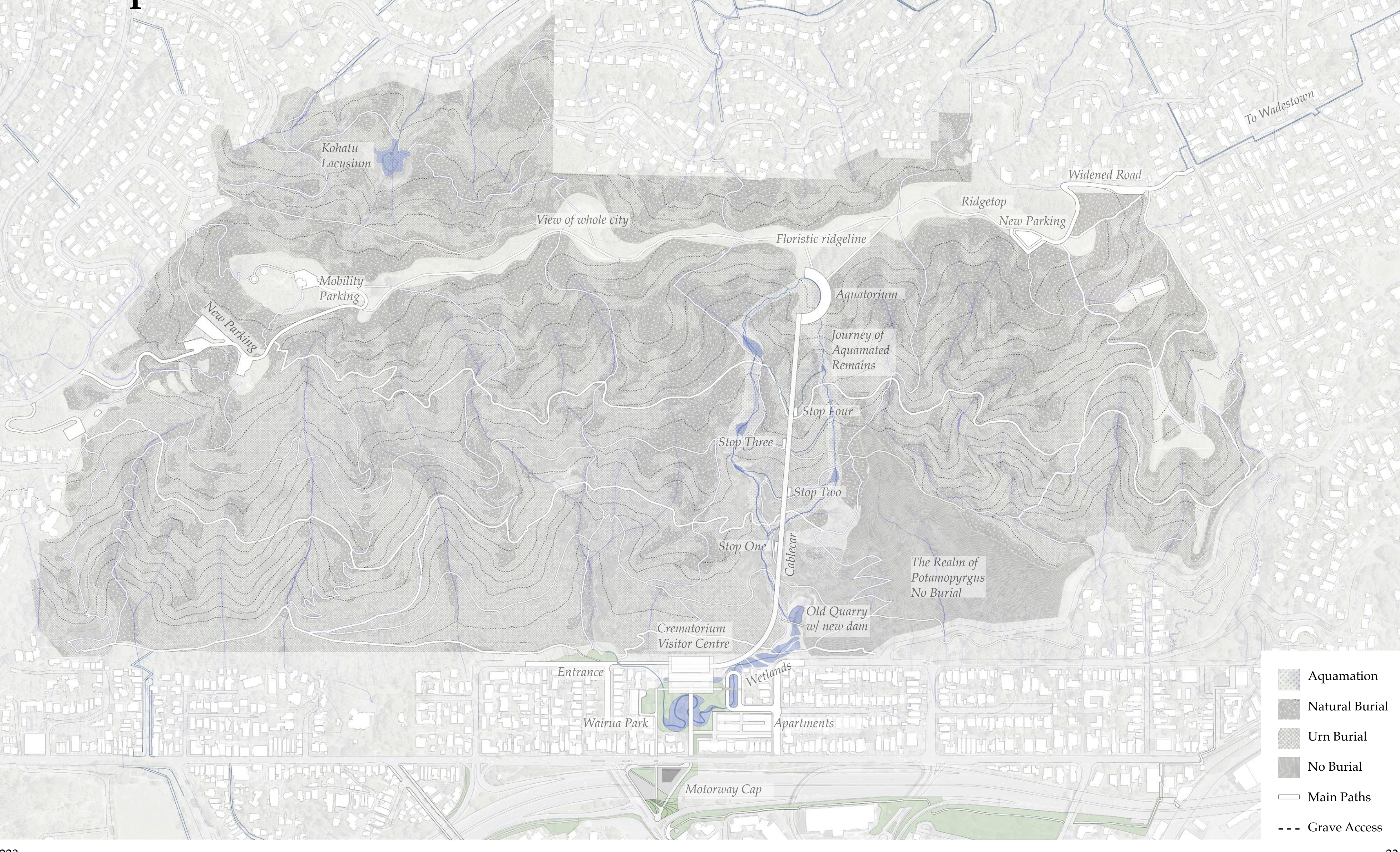




\section{Kohatu Quarry Lacusium Design}

Kohatu Quarry - Detailed scale

Exploring a potential experience of aquamation in the landcape and new tools in the design of cemeteries.

An existing waterbody and strong experiential characteristics.

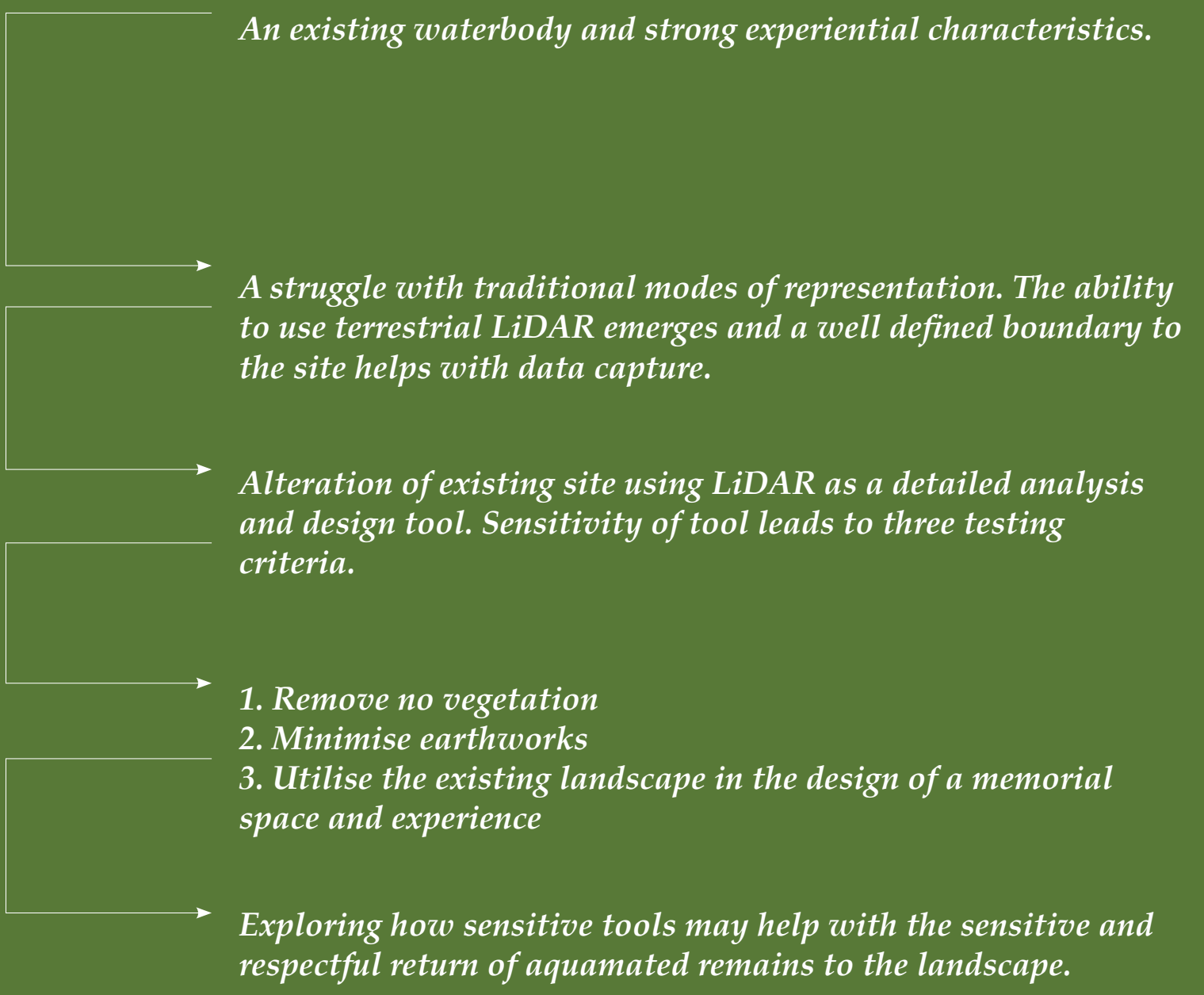

Suggested term for scattering place of liquid remains -

Lacusium.

From Latin lacus - pond, pool,

lake, also basin, reservoir.

Or in Te Reo, this might be -

hāpunapuna o wairua

A pool formed from spirits respectful return of aquamated remains to the landscape. 


\section{The Limits of Traditional Representation}

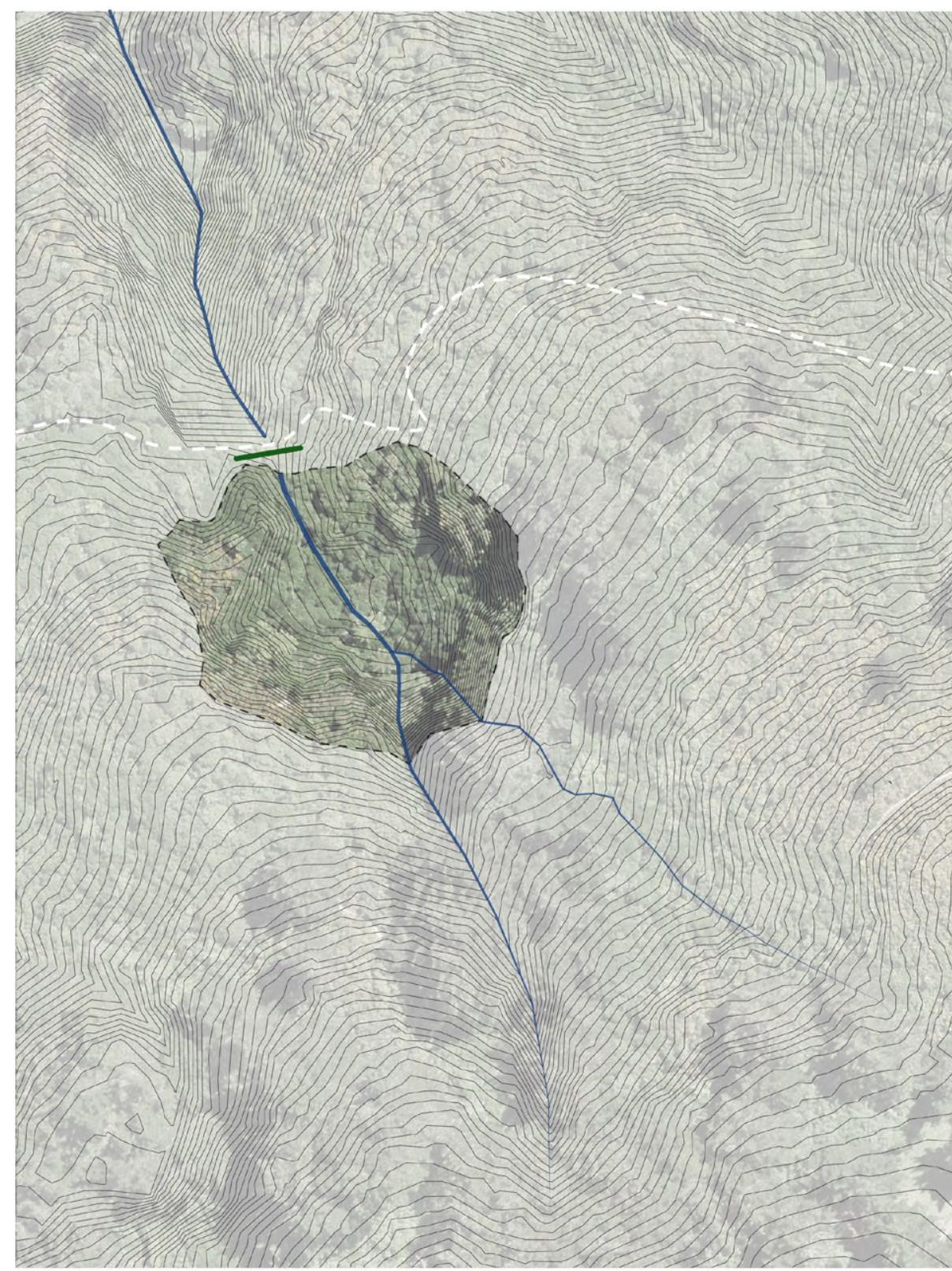

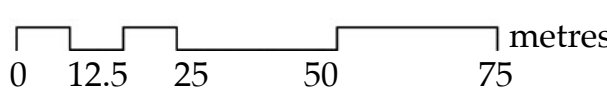

\section{Under Canopy Design Tools}

\section{Photography}

rely heavily on Geographical

Information System data. For mos open space projects and cemetery design, this works reasonably well.

But taking the Kohatu Quarry for example. Im interval contours allows therefore infer stream paths. We can see some broad vegetation types like pine, gorse, native forest and a few tree ferns from the aerial photograph as well as the current path. If a section was drawn we could understand the general spatiality of the topography.

As soon as we encounter forested space, it becomes immensely hard to propose any environmentally sensitive design without being able to see underneath the canopy.

Photography then becomes a usefu medium for understanding the spatiality and experience of the warps reality through a lens and therefore accurate measurements are very difficult to derive from photographs.
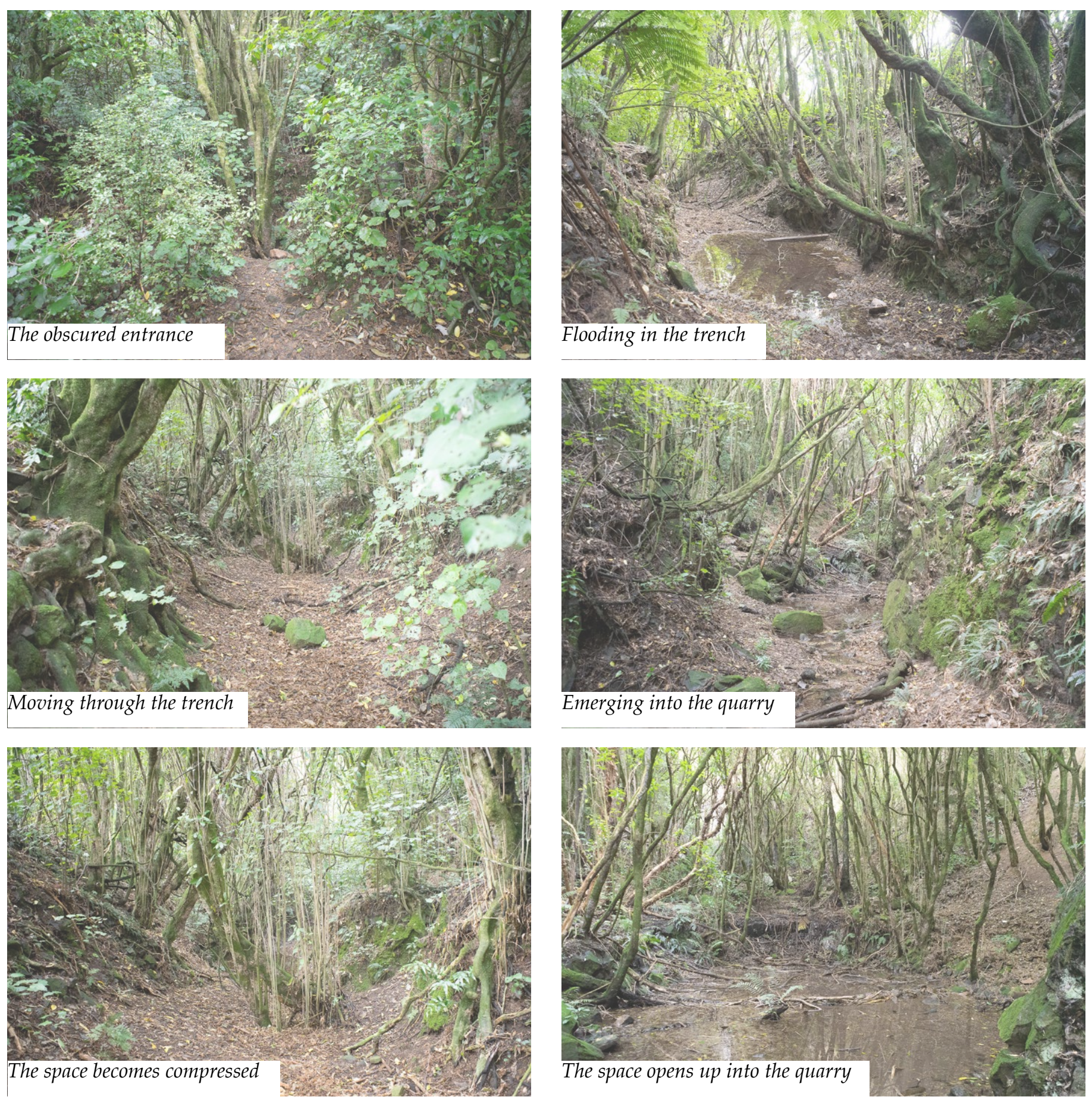


\section{Under Canopy Design Tools}

\section{Photography}
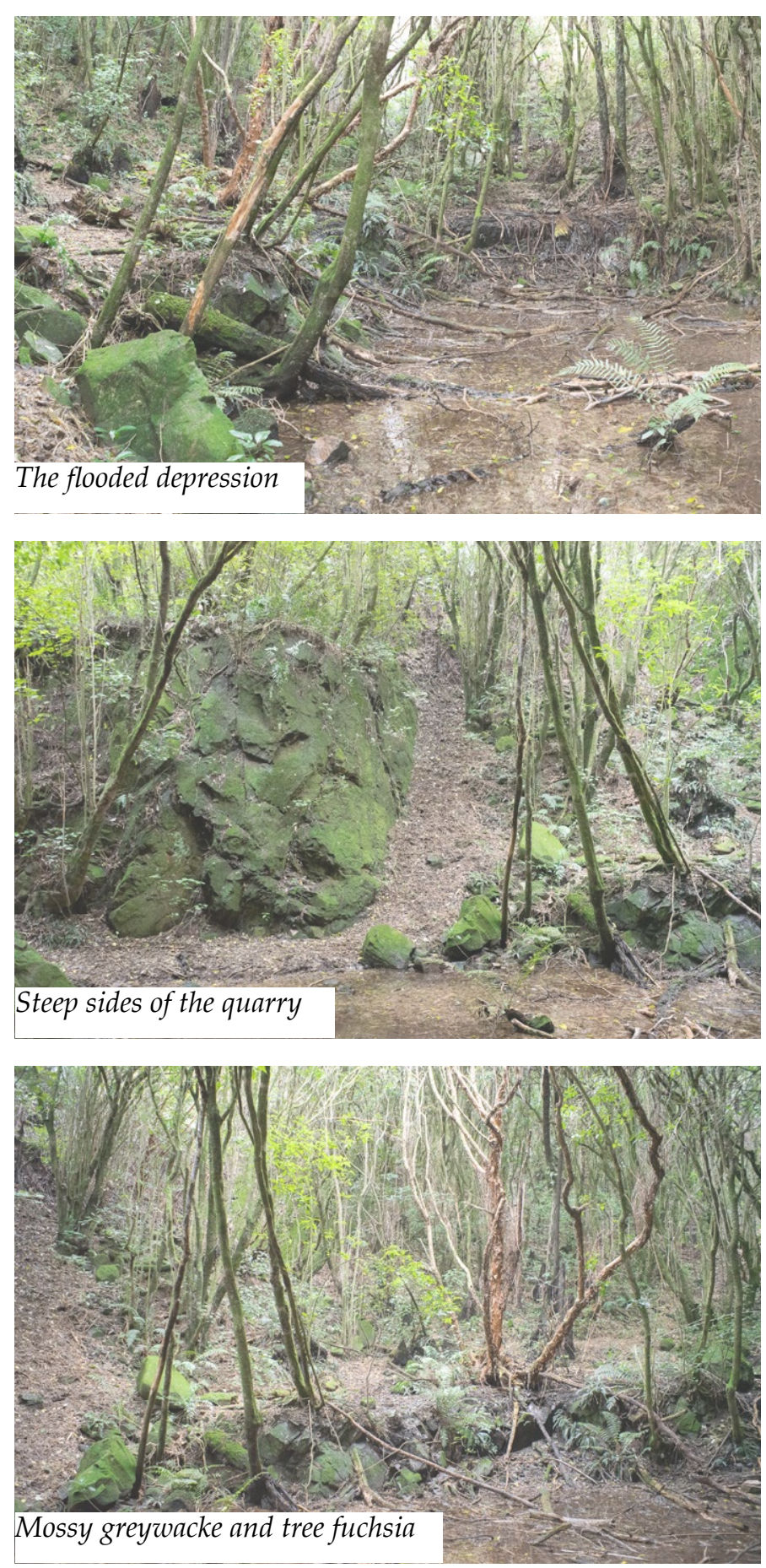

Preliminary Design of the Quarry
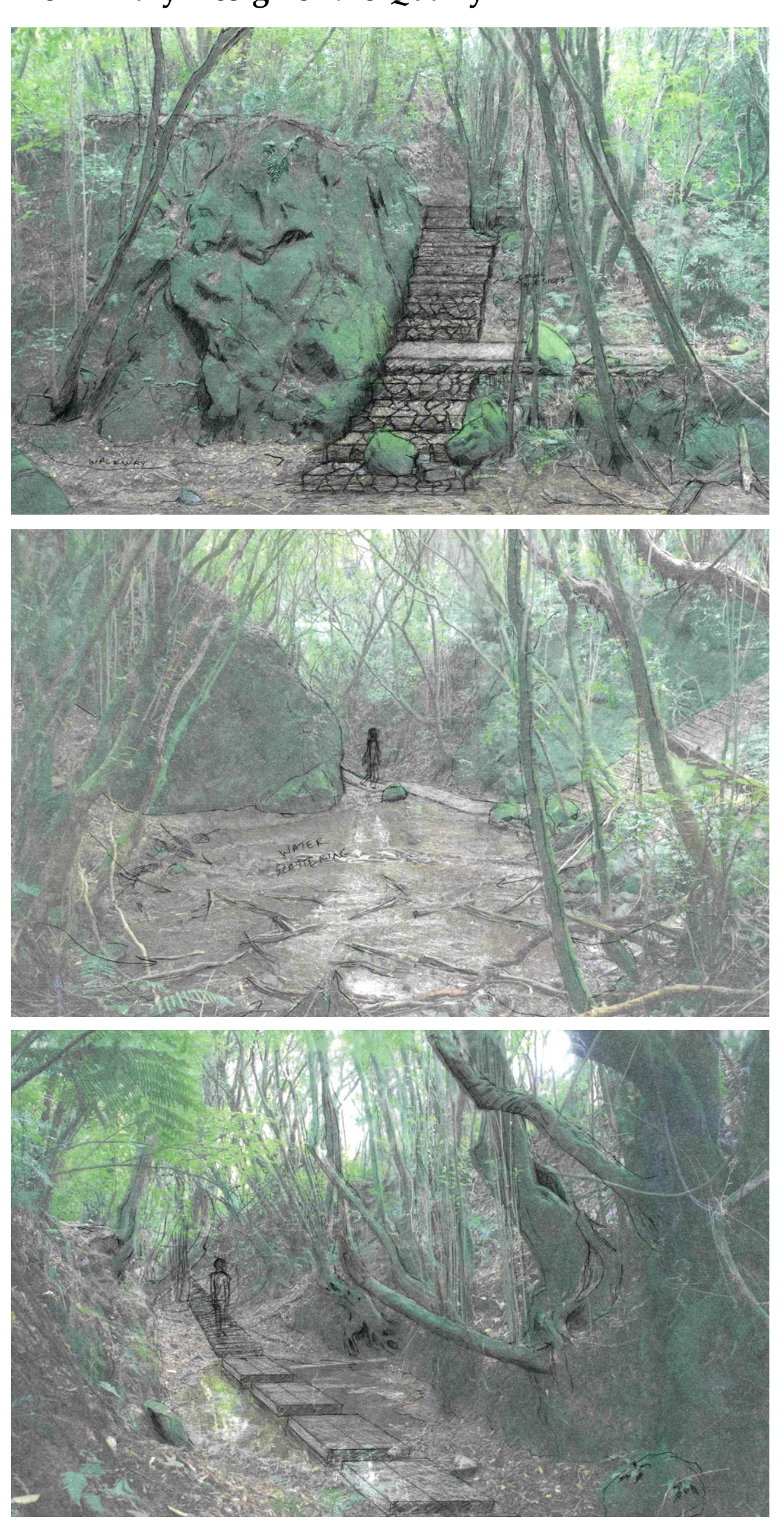

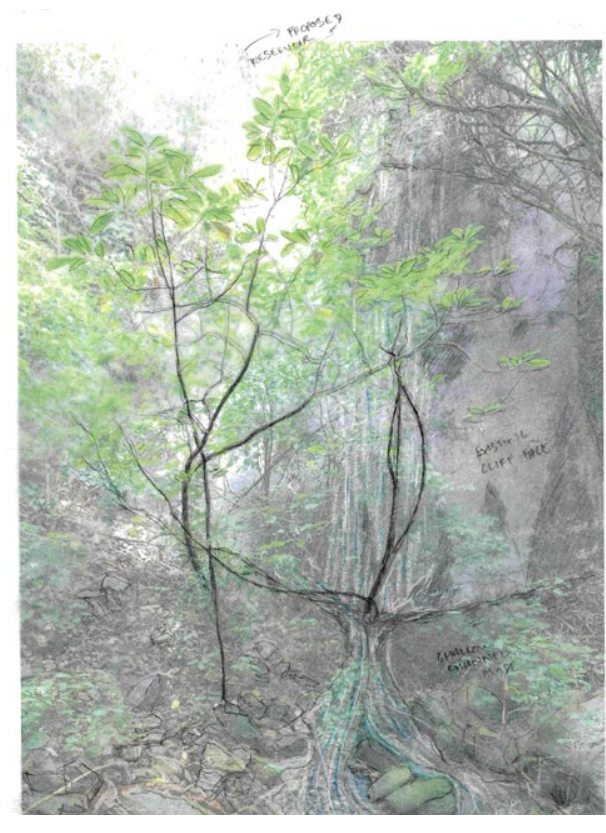

Not be able to see through the canopy in plan, necessitated design through photography. This series of design testing explored access issues to the with out getting stuck in mud.

The design wanted to explore using on site material such as the loose greywacke and working around the existing vegetation.

\section{The ephemeral waterfall}

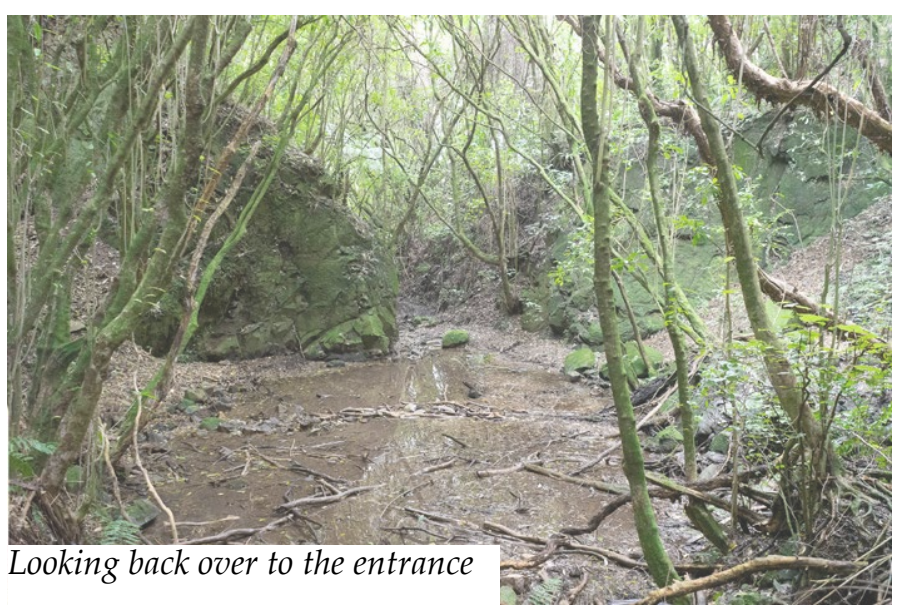


LiDAR in the Design of Forested Space

Sectioned ground plane of point

cloud showing location of scans with

the Leica BLK360. The area chosen

the Kohatu Quarry. A small part of Te

Ahumairangi, that currently requires

going off-track and is relatively

hidden. Its overgrown, amphitheat

like qualities make it a particularly

useful space in the context of a

memorial. As all sides of the quarry

are exposed rock, it helps form a
useful spatial boundary for LiDAR.

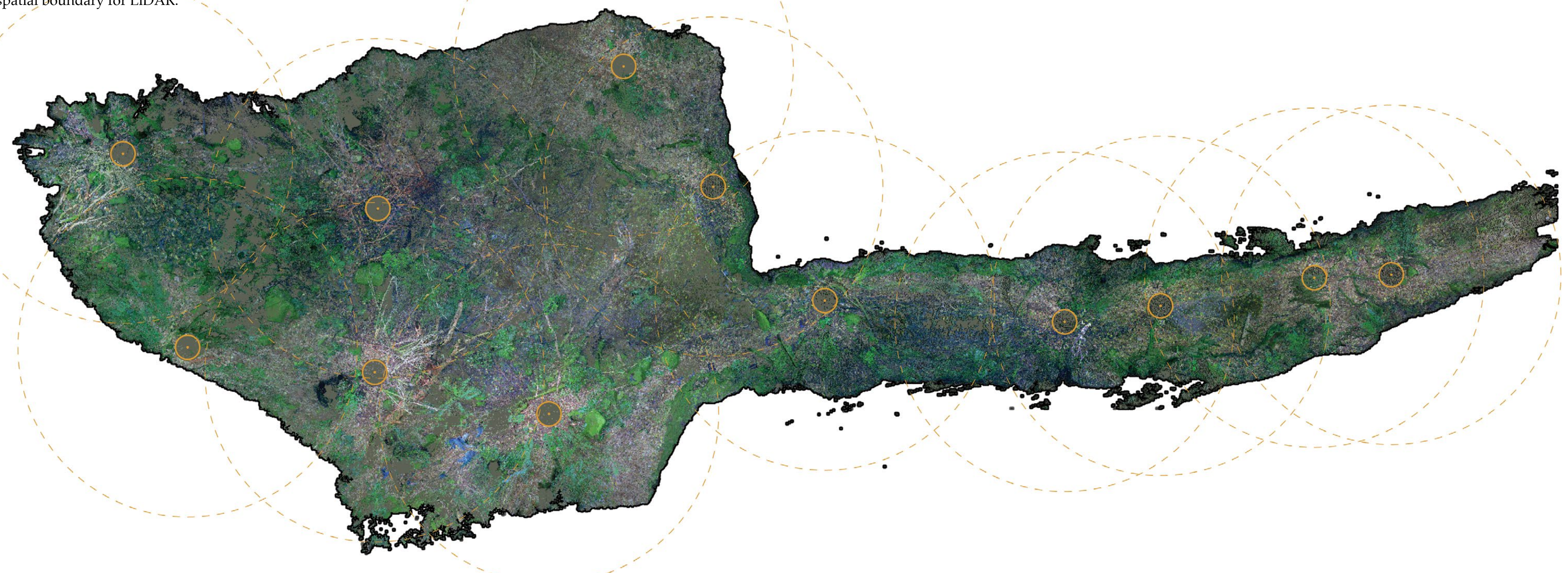




\section{Current Landscape Elements of Kohatu Quarry}

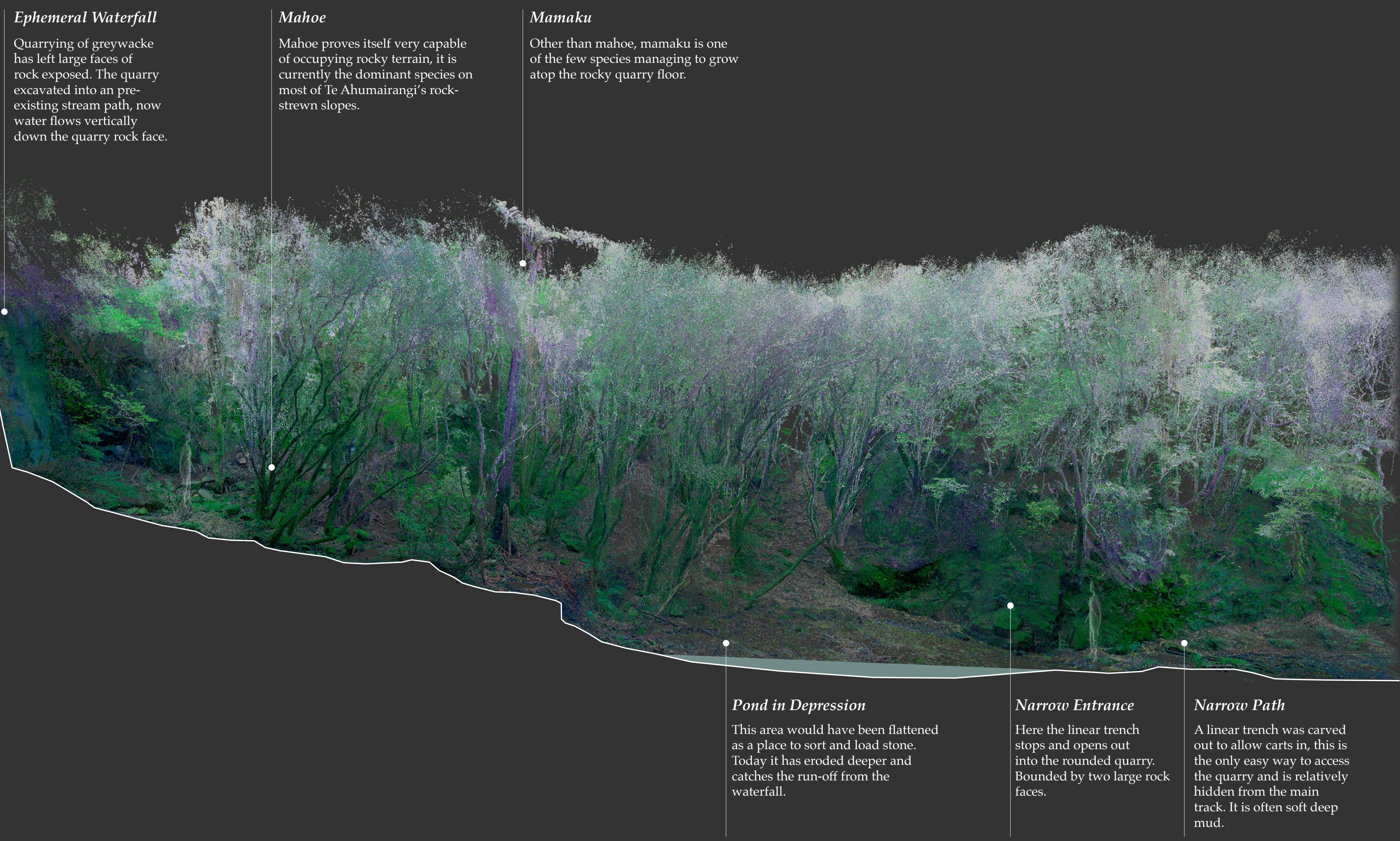




\section{Seeing the Forest for the Trees}

Point cloud models can offer a

precise view of forested space that

can allow for

It provides a new way of

understanding forested space that

photography and survey would not

be able to replicate. What can precise

measurements and locations of tree

species in space, offer design?

Three general realms can be sectioned through and understood in three dimensions.

1. Canopy - realm of the lea

2. Sub-canopy - realm of the . Ground - realm of trunk and root

Most often we find the realm of the trunk and ground easier to design with, as we can easily touch observe and measure it. Above head-height the forest tends to be harder to engage with. It is hard to map every branch. Understanding the forest is a complexity gradient starting at the trunk increasing through branches twigs and leaves.

\section{Point Cloud Section - Elevation}
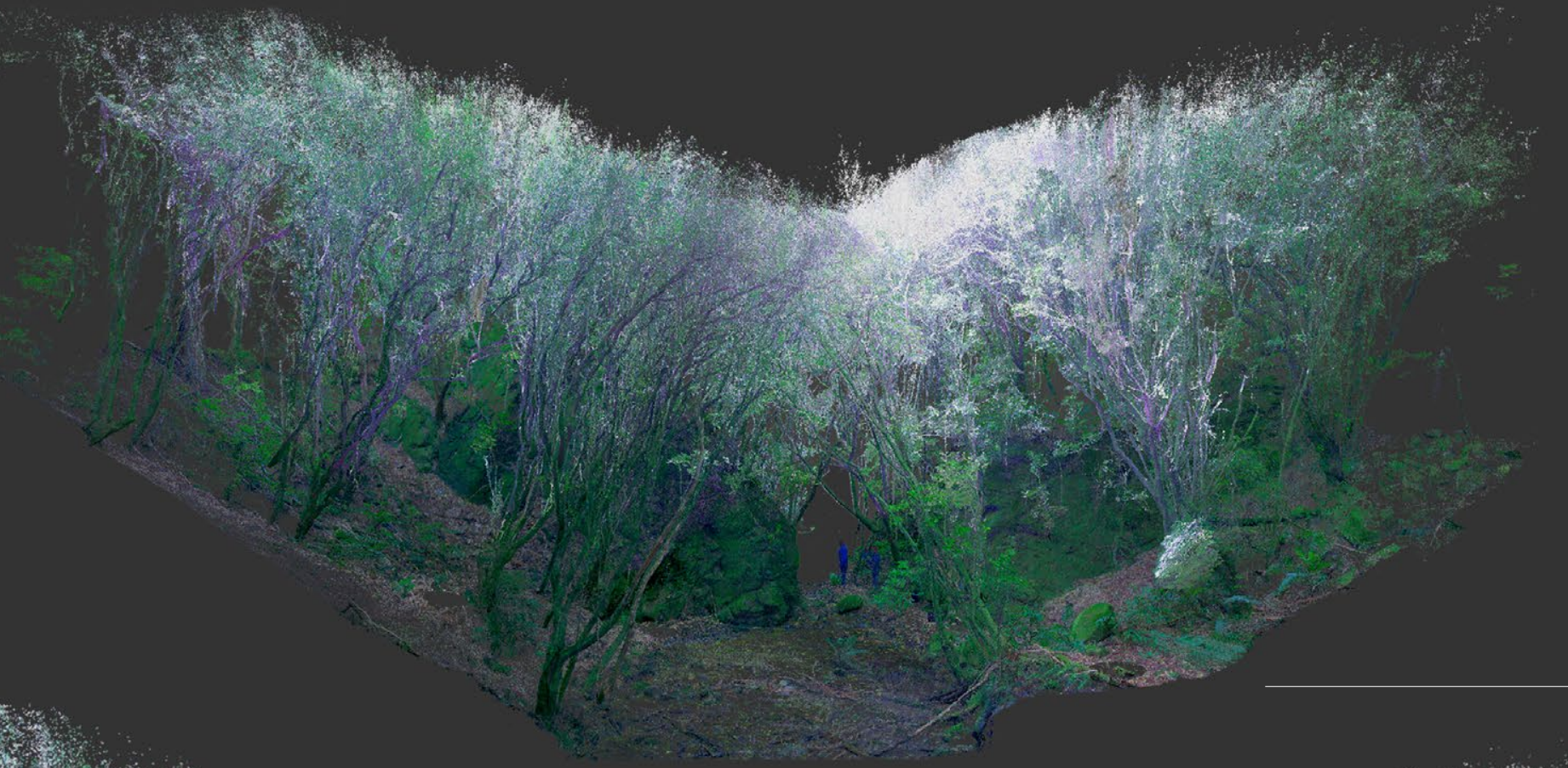

Lidar models appear on screen as a pixelated membrane, producing a luminescent ensemble of textures. including details and reliefs, vegetation

and infrastructure... stunningh

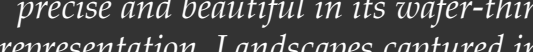
this mode reproduce a pointillistic veil of scintillating electronic point-clouds that look like dew drops minutely covering the entire surface of the land."136

${ }^{36}$ Girot, Topology, 81 The Forest

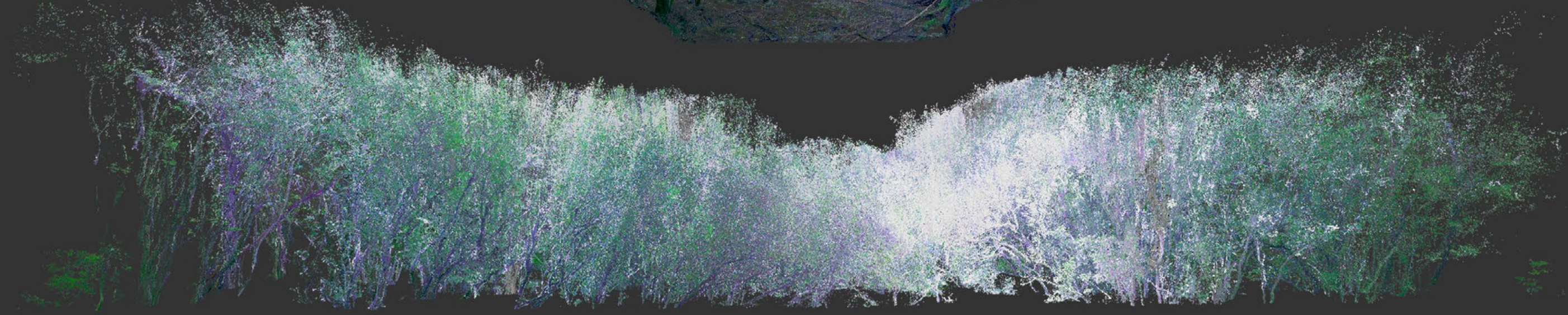

Realm of the Leaf

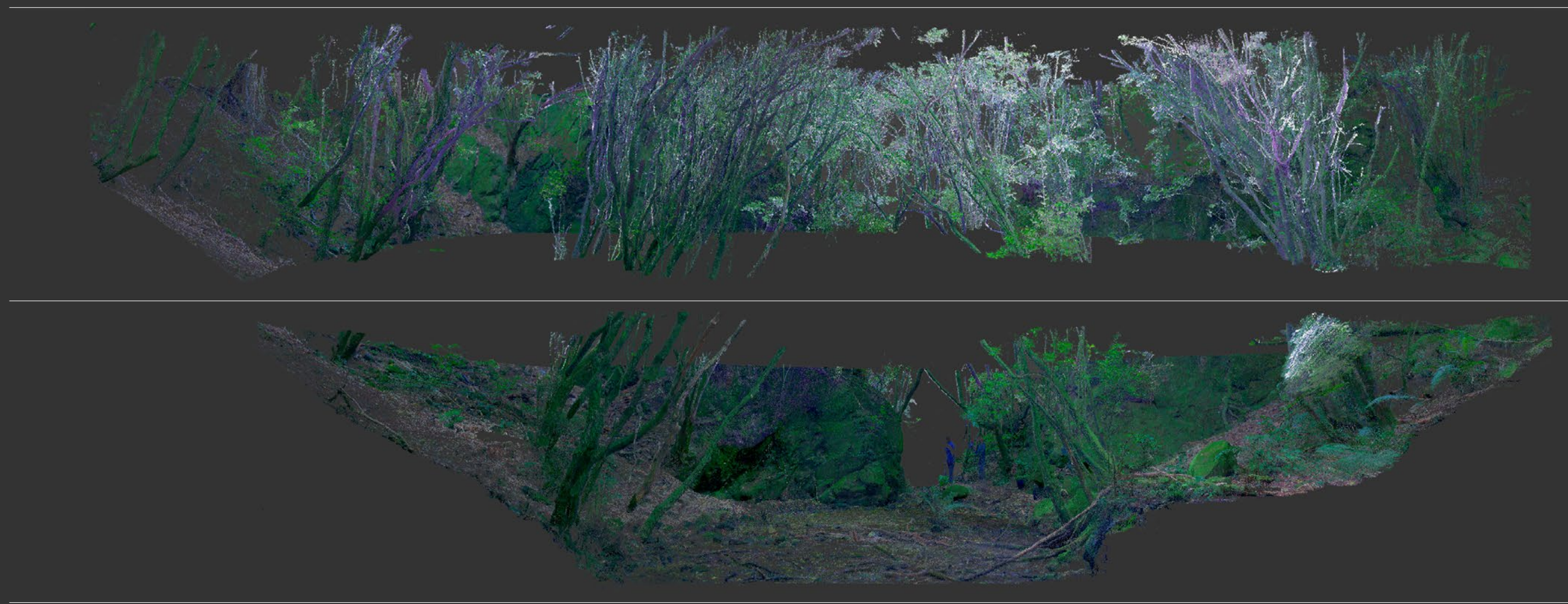

Realm of the Branch 


\section{Point Cloud Section - Plan}
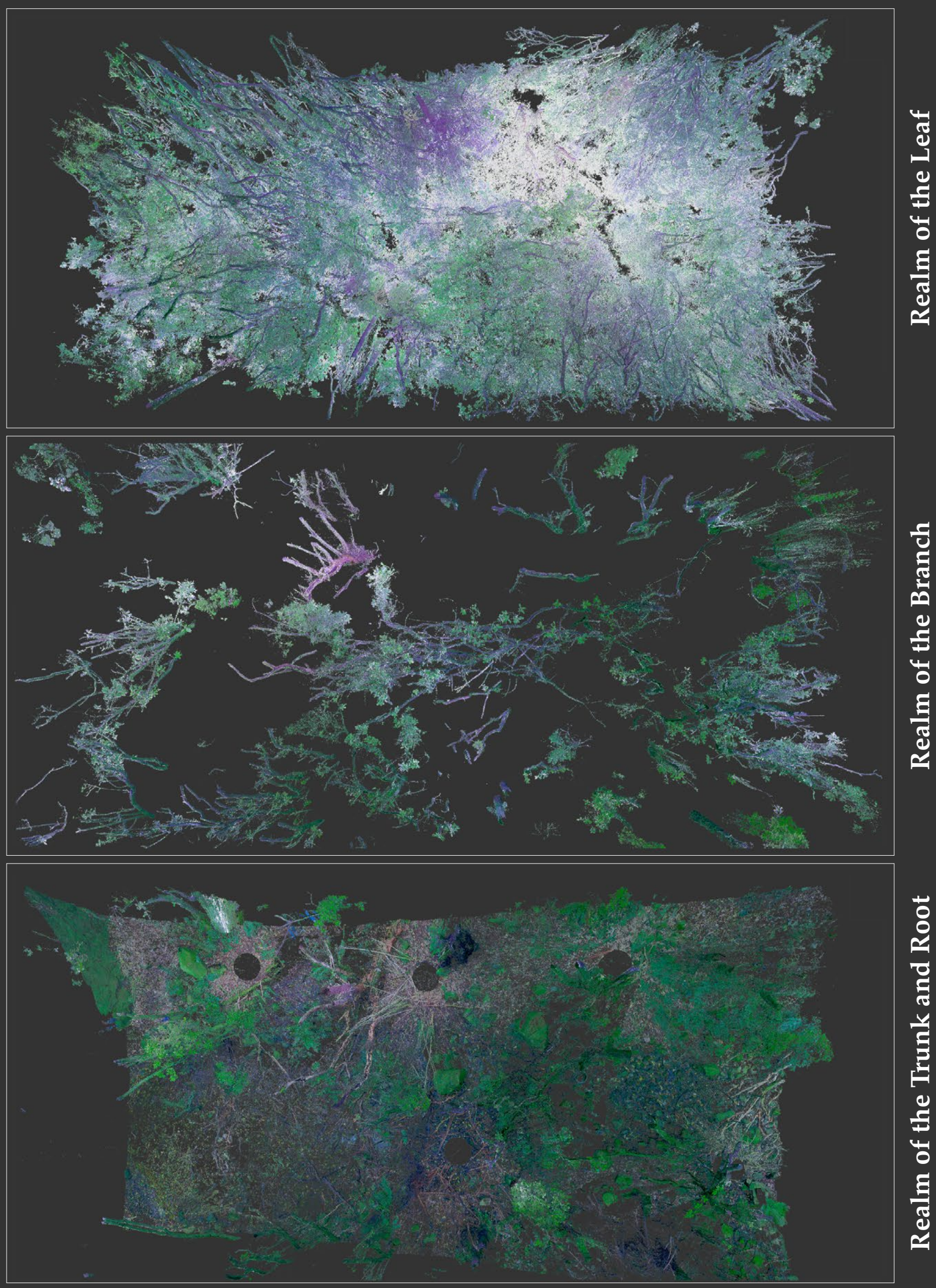

\section{Point Cloud Section - Perspective}

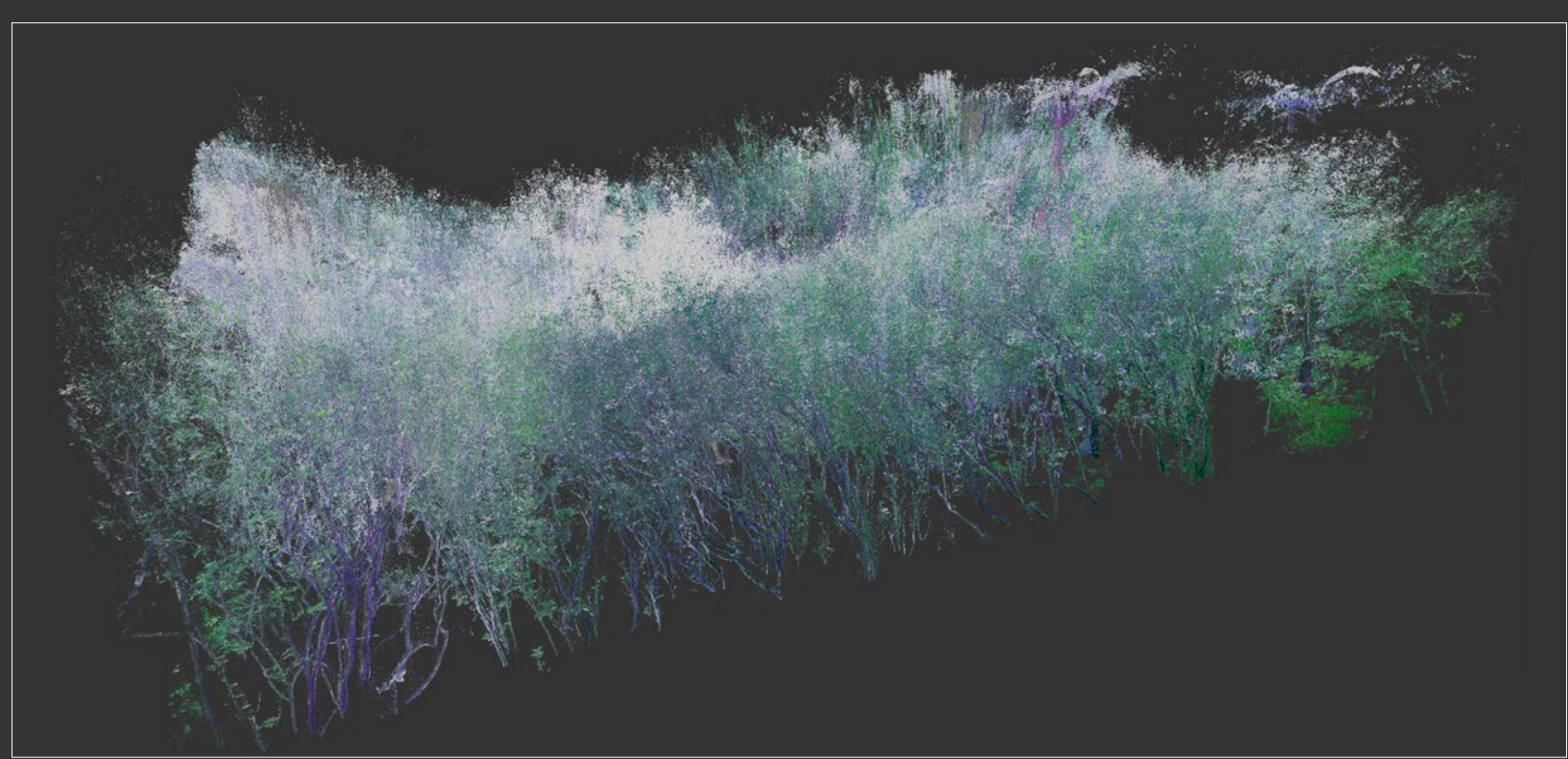

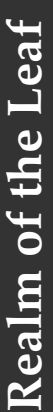
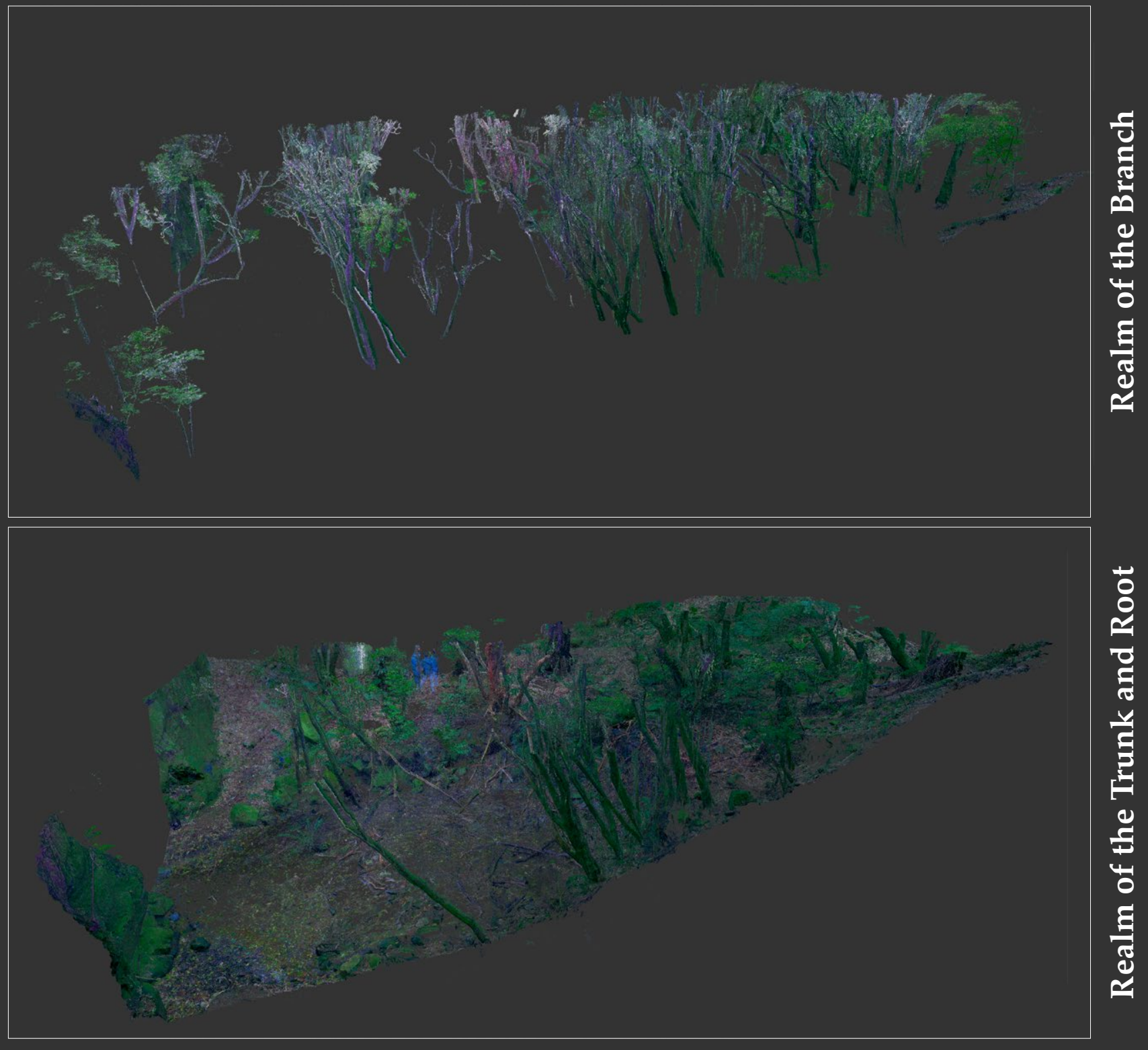

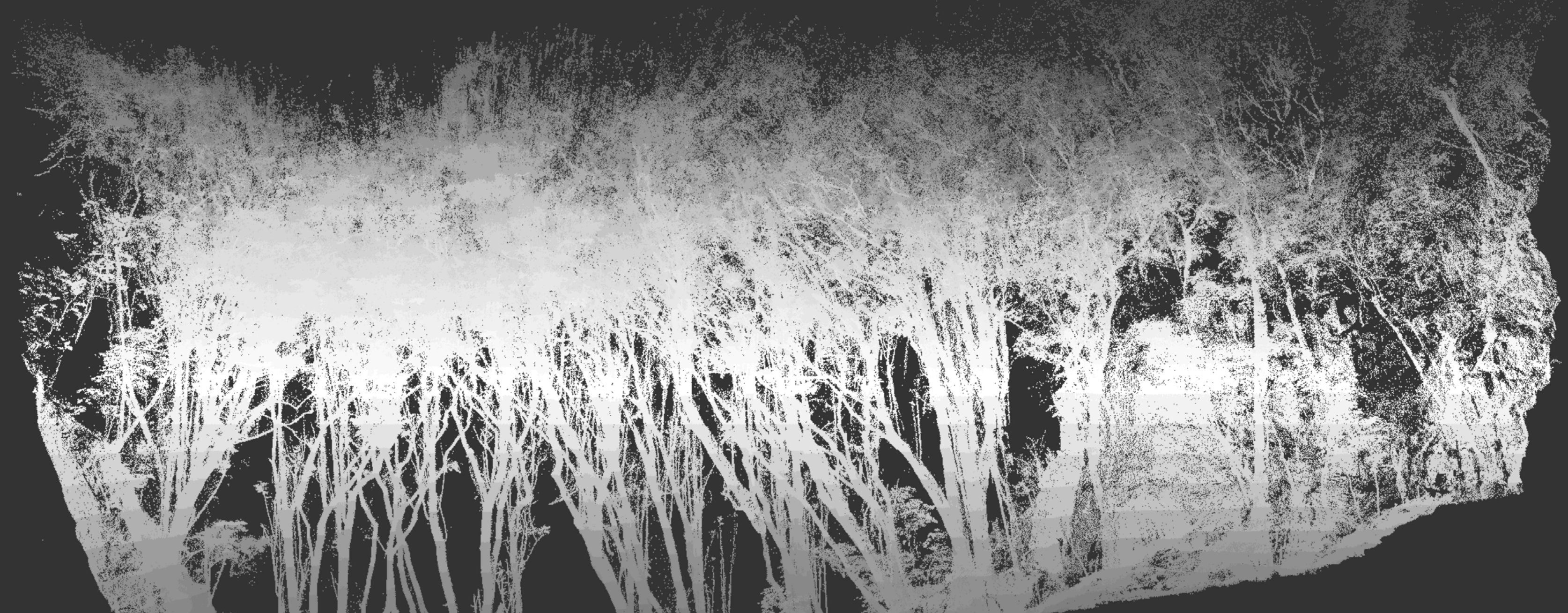

Understanding elevation in the forest. Precise heights of the trees
can help to understand where shifts in spatiality of forest occur.

For example the trunks of mahoe split into branches at around $1 \mathrm{~m}$ off the ground. At $4-5 \mathrm{~m}$, branches separate out further into smaller branches and twigs. The top of the canopy currently rises to $14 \mathrm{~m}$. 


\section{Precise Contour}

Using AutoCad Civil 3D, a point

cloud can be turned into a surface.

This surface can the be contoured

to any precision of contour $(0.25 \mathrm{~m}$

was chosen). These contours allow
for a more precise understanding

for a more precise understanding of microtopography and therefore,

how water moves through the

design methods that are more

sensitive to the existing landscape

condition.

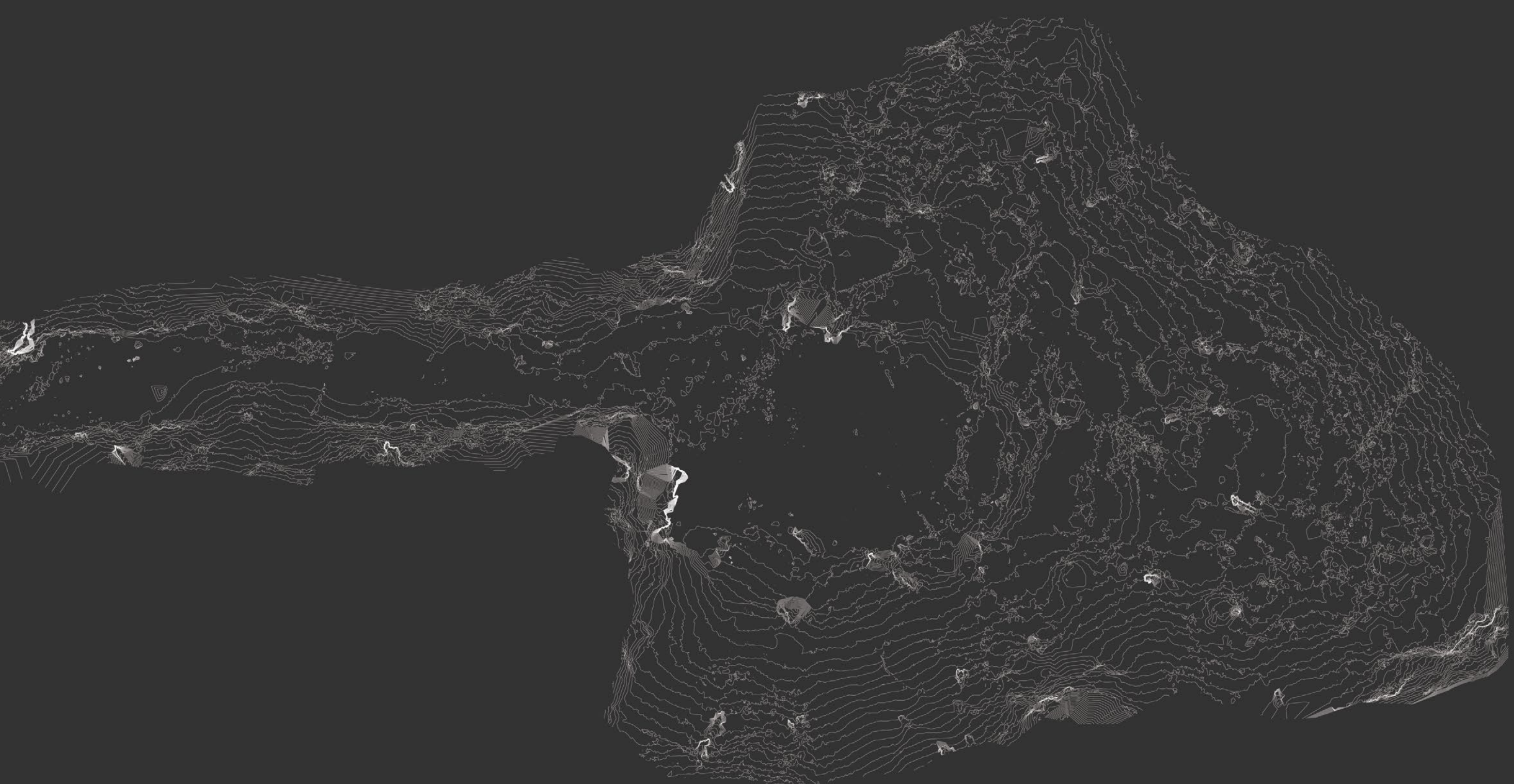



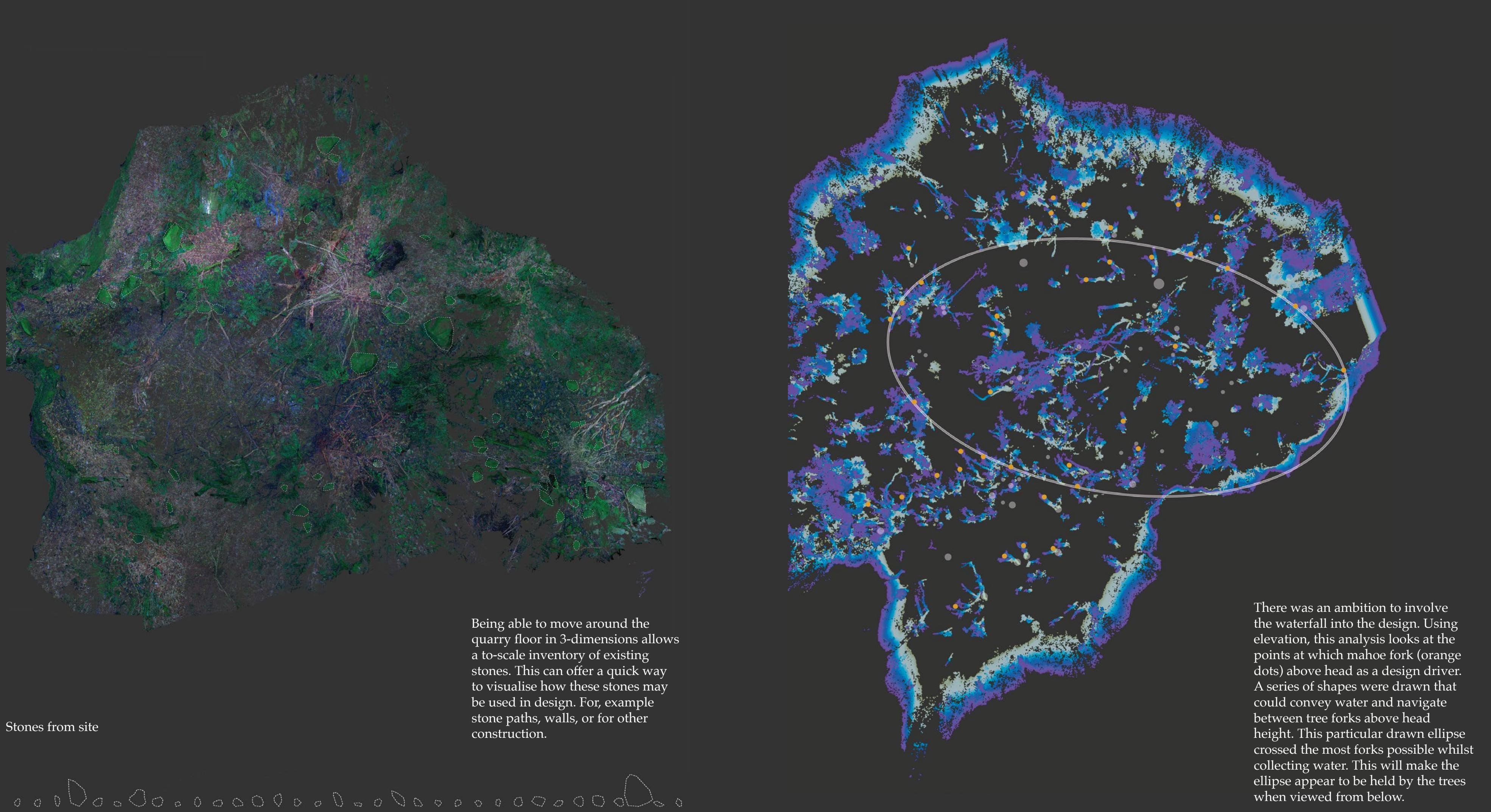

0000000000000000000000000000000 
Site Plan - Final Design

oardwalk

A board walk is proposed to raise

visitors off the boggy ground and

away from aquamated remains. It

weaves between tree trunks and

requires no removal of vegetation or

change of terrain. The preciseness of

LiDAR allows for a remote design of

this. The walkways perching nature

gives a sense of the sacred or tapu to
the liquid remains and ground below.
Aquamation Basins

These are proposed stone basins placed near

the path and under the line of falling water from the overhead channel. As the water falls it collects and sprinkles in the basin to suggest the interment of liquid remains here. It travels down from the basins and into the main poo

before making its way through the wider
landscape .

Stone Path

The ston

inventory is used

to create sections

of stone pathways

that connect

to the existing

landscape and

merge into the

stone aquamation

basins.

Q Section bb (3).

Ellipse of Water

The ellipse

shape becomes

an over head

steel channel

that is built into

the rockface

and collects

and distributes

water from the

waterfall.

The channel

is design to

overflow to create

a curtain wall of

water dripping

from the canopy
above.
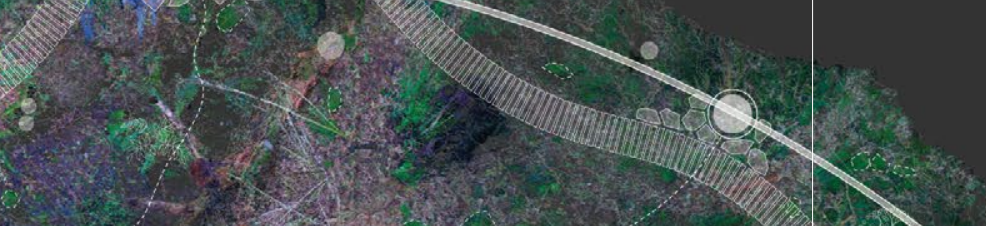

$=0$

(
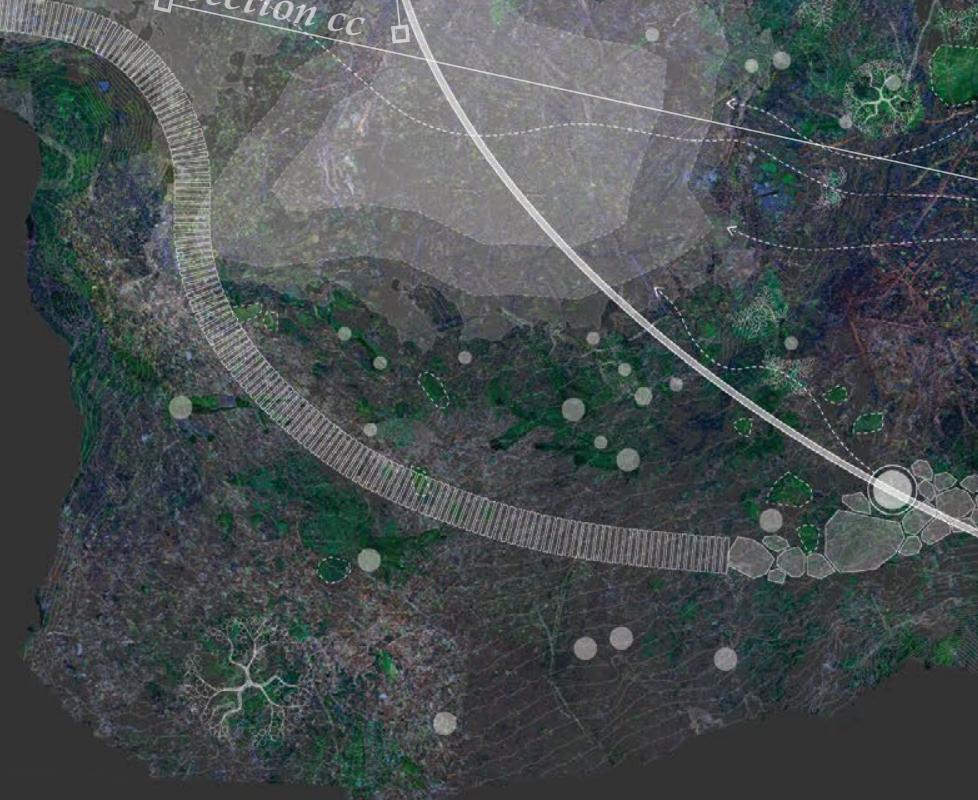


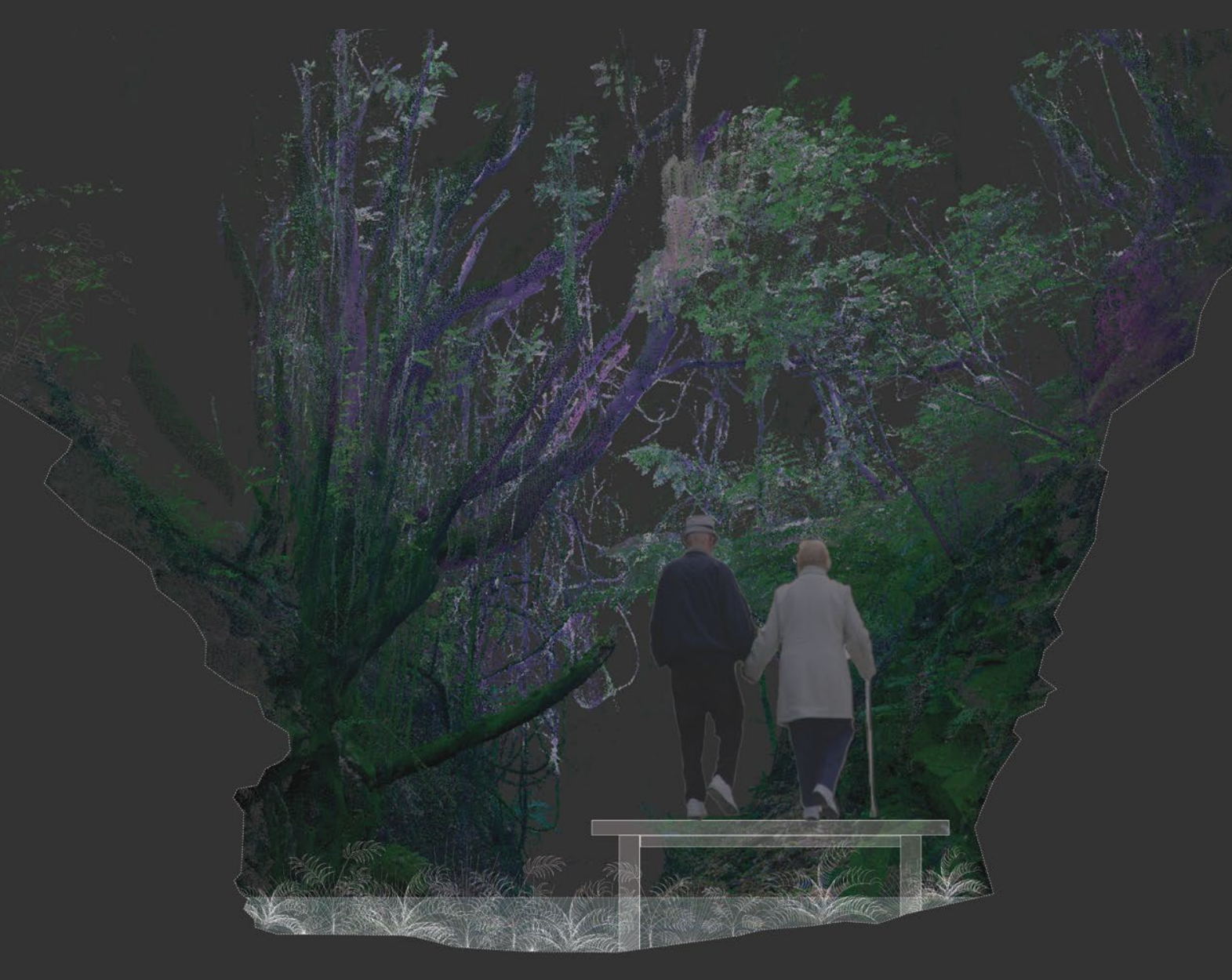

Section aa

A proposed design section through

the existing narrow trench entrance.

The increase in water from interred

aquamated remains in the Lacusium

will raise the current water level and flood the trench further.

A boardwalk allows a flat and

easier accessibility. The planting of
native the swamp fern - Cyclosorus

interruptus and wetland sedge -

Isolepis prolifera are proposed species

for the swampy trench.

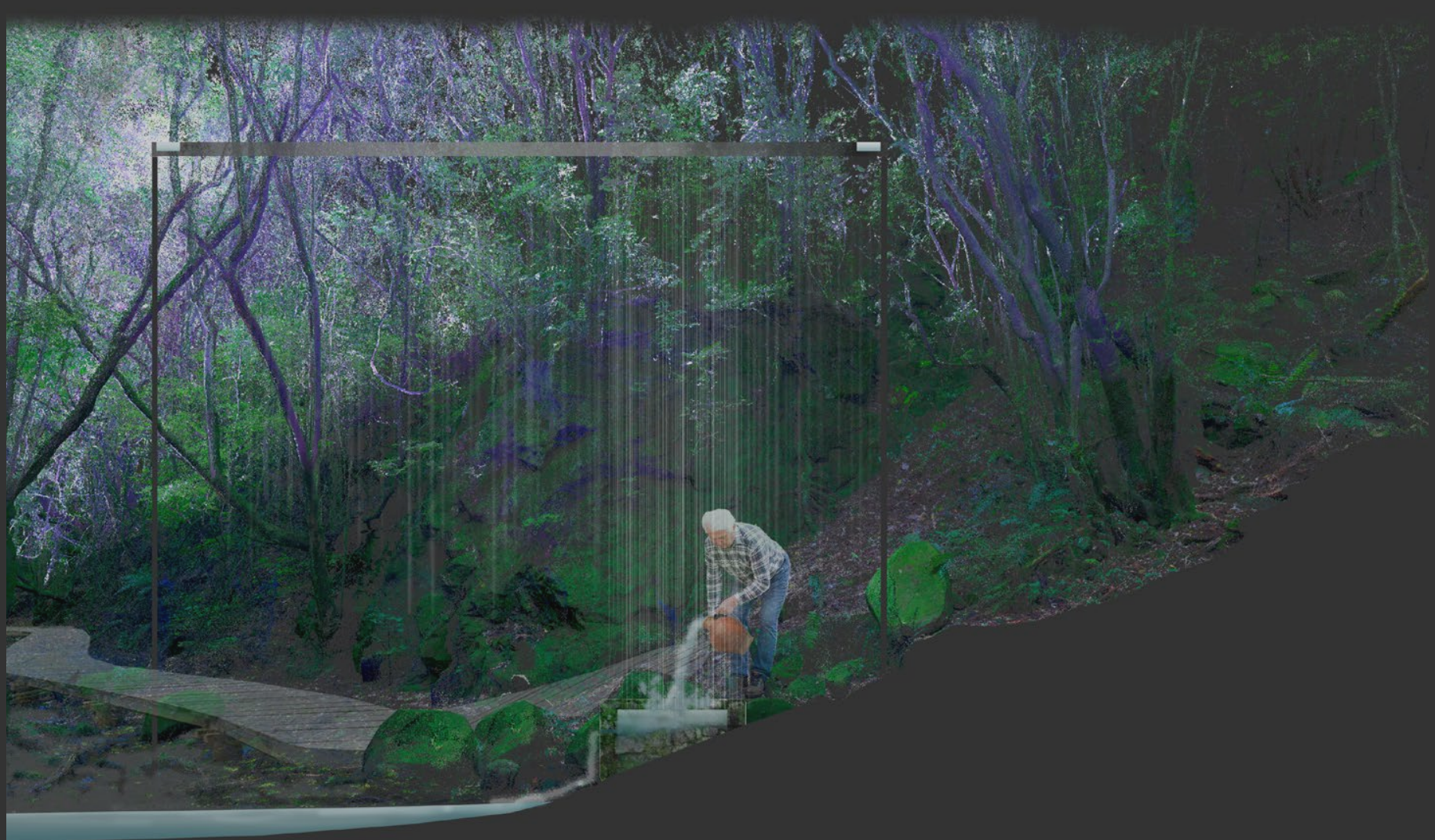

Section $\boldsymbol{b} \boldsymbol{b}$

A proposed design section through

a basin. These basins constructed

from on site stone, collect falling

A mourner returns their aquamated

loved one (in an urn) back to the

land. 


\section{Section cc}

\section{The elliptical channel is on a $1^{0}$ slope} toward the main pool. It is on $5 \mathrm{~cm}$ deep, so that water collecte rom the waterfall overflows. Abour the aquamation basins, small $2 \mathrm{~cm}$ diameter holes allow a greater amount of water to fall into the basins.
The channel is held up on steel

prevents leaf fall from blocking the flow. produced by the group of trees it

encapsulates.

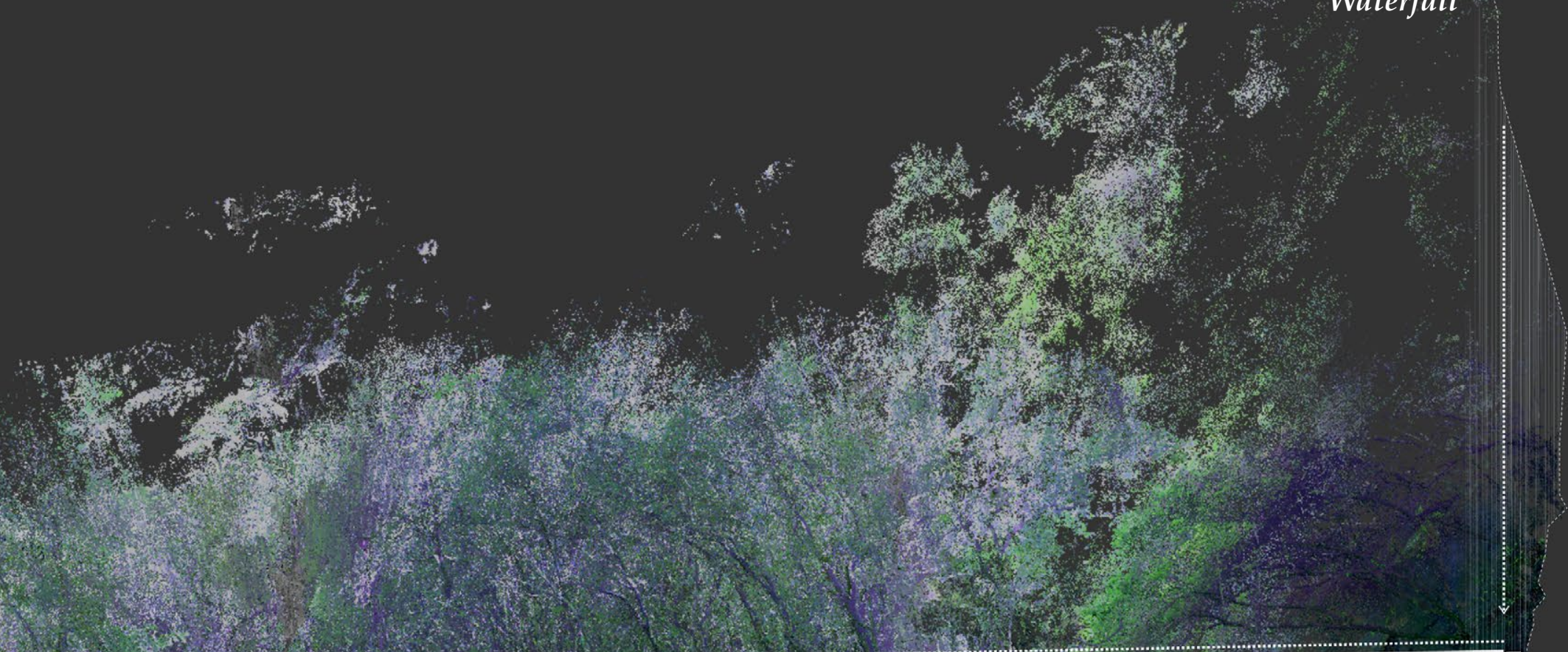

Waterfall (t)

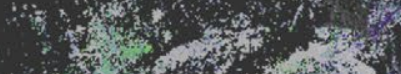

r.
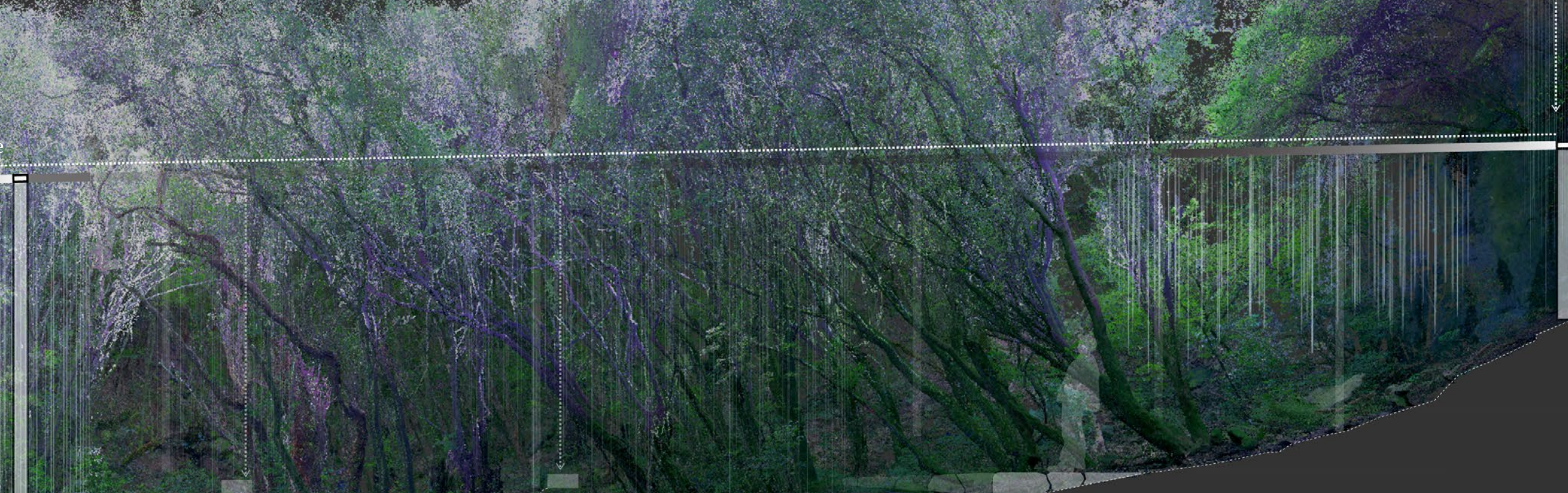

$2+1$
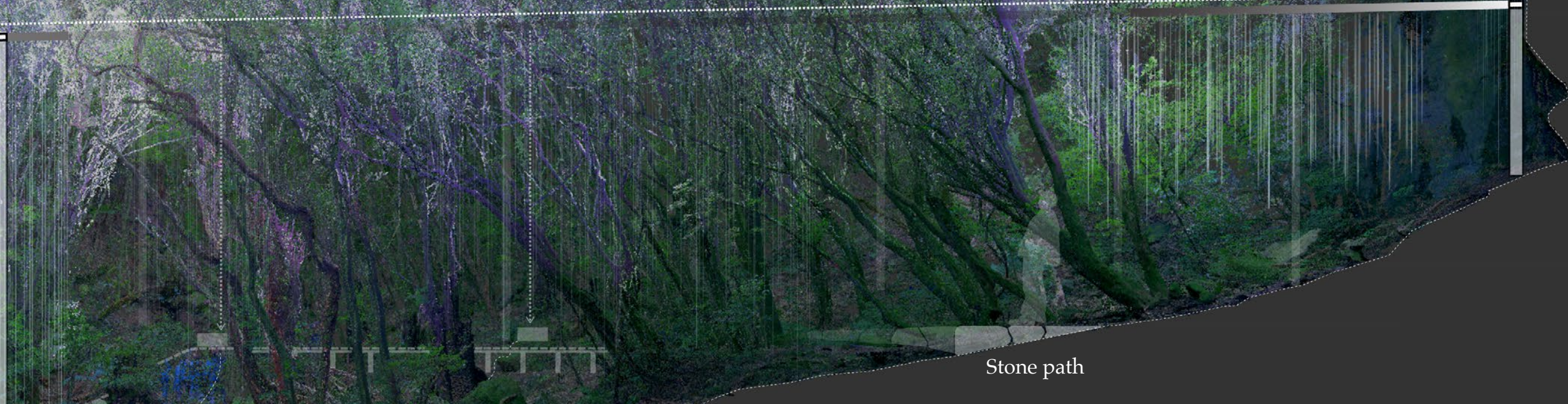

Stone path

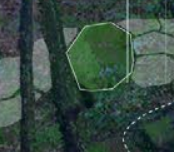

列




\section{Chapter Seven - Reflection on Research Practice}

This research set out to explore how landscapes of burial could become re-entwined with human culture and ecology. With an ambition of designing; an urban cemetery that changes our relationship to death and life, through engagement with the experiential, ecological, social and sacred aspects of Aotearoa's landscape.

\section{Discoveries and Reflection}

There has been a range of functional and economic concerns in the design of cemeteries that has seen them become further distanced from the cultural and ecological realm. A critique of planning and policy through a comparison of site selection criteria, helped steer the research toward new possibilities in cemetery design and planning. A site potentials in the way we may relate to Aotearoa's landscape in the context of death. Fieldwork was important to this research, as there has been very minor engagement or publication on cemetery design in Aotearoa. A selection of Aotearoas's current cemeteries were investigated for how they have traditionally been designed, whilst discovering a range of underappreciated aspects in cemetery design. Together this fieldwork resulted to $70 \mathrm{~km}$ of walking and experiencing the landscape and helped form an innate understanding of the vegetation, geology, fauna, hydrology topography other landscape elements of Te Ahumairangi where data was unavailable.

The relationship between burial and topography became agent in the research, this led into being able to understand the possibility for burial in Wellington's steep Town Belt and Te Ahumairangi. Topography seems to be the most limiting landscape condition to today's modern cemetery design. The less restrictive space requirements and lack of necessity for flat land offered by alternative burial methods have the ability to change the cemetery as we know it um burial and aquamation may even further the possibilities of what is possible in cemetery landscape design. Studies of topography in this research shaped where differing burial methods could be implemented.

Geology also determined the depth at which body and urn burial was possible and in tandem with topography p. Hydrological flows and catchuarries in the site and thork for aquamation and streams became an important part of returning this liquid to the land in a respectful way.

A close study of living beings (flora and fauna) appears an endless, but highly rewarding task in cemetery design. The vast range of species explored have many interconnected relationships and structure experience in completely different ways, these connected cycles became one of the main focuses. Flora and fauna studies allowed the dead (past) to interact with life in the future, with these interactions experienced by people and therefore able to alter our culture in the present. Utu, whenua and other traditional understandings were useful for conceptualising how these for a site specific send-off and creates a closed-system of resource use in a cemetery.

Terrestrial LiDAR was adopted later in the research trajectory and engaged with tentatively at the start, due its large data sets and required software skill. It ended up becoming a major element in the design, after a familiarity with it was formed. It is incredibly precise and allows for a range of design under canopy that would only be possible on site. Further to this, it also shows new potentials in the design of forest spaces. An x-ray like vision into the canopy creates an understanding that does not seem possible with other tools and led to design that reacts to this under-explored world of canopy space.
Further Areas for Research

Terrestrial LiDAR is limited by its surface based data generation and representation. For this reason, it was most useful when it came to the design of an aquamation space, where the main component of the design was surface water. The research was focused within government owned land and digging large holes in reserve land was not an option. Investigation of Ground Penetrating Radar (GPR) was outside the scope of this research but could prove useful in the design of alternative burial cemeteries where an understanding of subsurface geology and soil depth is crucial to the type and method of burial.

A range of traditional Māori understandings were found to be stimulating in the design of cemetery space, but the author acknowledges that closer work with specialists in these fields is incredibly important for Aotearoa's future cemeteries. This research also acknowledges concerns and laws around ashes being returned to waterways, if aquamation does become legal here this will likely raise similar concerns.

Another layer this research would benefit from is in the realms of land management and care. The exact layout of gravesites was not engaged with as other parts of the research took precedence. Thorough research into plot tenure shapes and sizes of plots, plot maintenance and marking would benefit further research into alternative burial methods.

Multiple smaller cemetery sites were outside of the set scope, design-led research with a series of linked sites throughout the Town Belt be a beneficial exercise. The Town Belt arcs around and encapsulates the city, if a burial belt were to be implemented a range of new opportunities would arise and lessen the need for large infrastructure and spending around a single site.

\section{A New Practice for Cemetery Design}

This research used an experimental practice that intertwines a vast array of potentials in cemetery design. It did considerations, findings and underexplored relationships, that can be tapped to catalyse the discipline of landscape architecture and cemetery planning into action. 


\section{Bibliography}

Awatere Huata, Donna. Māori Sovereignty. Auckland, N.Z: Broadsheet, 1984.

Bowring, Jacky. Melancholy and the Landscape : Locating Sadness, Memory and Reflection in the Landscape. New York: Routledge, 2017.

Braunius, S., McManus, R., Elliot, M. Death and Dying in New Zealand. Radical futures series. N.Z: Freerange Press, 2018.

"Cemeteries Management Plan Review". 2020. Wellington City Council. https:// www.letstalk.wellington.govt.nz/cemeteries.

Deed, Stephen. Unearthly Landscapes : New Zealand's Early Cemeteries, Churchyards and Urupā. Dunedin, New Zealand: Otago University Press, 2015.

Diakiw, Larissa. 2019. The Disneyland of Death. [online] Hazlitt. Available at: $<$ https: / /hazlitt.net/longreads/ disneyland-death $>$ [Accessed 5 December 2020].

Fisher, Julie, and Bob Reed. 2013. "Risks Posed By Dead Bodies After Disasters". Who.Int. https:// www.who.int/publications/m/item/risksposed-by-dead-bodies-after-disasters.

Girot, Christophe. Topology : Topical Thoughts on the Contemporary Landscape Berlin: Jovis, 2013.

Haami, Bradford. Pūtea whakairo: Māori and the written word. Wellington N.Z: Huia Publishers in association with the Ministry for Culture and Heritage, 2004.

Hayward, Bruce W. and John T. Diamond. Prehistoric Archaeological Sites of the Waitākere Ranges and West Auckland. Auckland, N.Z: Auckland Regional Authority, 1978.

Hunt, Nick. 2020. "Dead Wood.” Emergence Magazine. Accessed November 8. https://emergencemagazine.org/story/dead-wood/.

Huxley, Aldous. After Many a Summer. St Albans: Triad, 1976.

Jackon, Thomas. The Works of Thomas Jackson, D.D.: Sometime Presiden of Corpus Christi College, Oxford, and Dean of Peterborough, Volume 4. Michigan: University Press, 1884

Lee, Tom. "Place and Identity: What Can We Learn from the Dead?" Craft + design enquiry 7 (2015): 99-

Luciani, Domenico and Boschiero, Patrizia. Kongenshus Mindepark : The International Carlo Scarpa Prize for Gardens Treviso: Fondazione Benetton
Lynch, Kevin. What Time Is This Place? Cambridge, U.K: MIT Press, 1972

Park, Geoff. Theatre Country : Essays on Landscape \& Whenua. Wellington N.Z: Victoria University Press, 2006.

Park, Geoff. Ngā Uruora = The Groves of Life : Ecology and History in a New Zealand Landscape. Wellington, N.Z: Victoria University Press, 1995

Polan, Shira, and Gina Echevarria. 2019. “What Happens To The Human Body After 100 Years Inside A Coffin". Business Insider Australia. https: / / www.businessinsider.com.au/how-long-it-takes-human-body-decomposegrave-coffin-2019-8? $\mathrm{r}=\mathrm{US} \& \mathrm{IR}=\mathrm{T}$

Riley, Murdoch., and Brian Enting. Māori Healing and Herbal : New Zealand Ethnobotanical Sourcebook. Paraparaumu, N.Z: Viking Sevenseas
N.Z., 1994.

Serres, Michel, Margaret Sankey, and Peter Cowley. The Five Senses: A Philosophy of Mingled Bodies. London: Bloomsbury Publishing Plc, 2009.

Wassilieff, Maggy. 2007. "Horticultural Use Of Native Plants". Teara.Govt. Nz. https:/ / teara.govt.nz/en/horticultural-use-of-native-plants.

Wolschke-Bulmahn, Joachim. Places of Commemoration: Search for Identity and Landscape Design. Washington, D.C.: Dumbarton Oaks Research Library and Collection, 2001.

Worpole, Ken. Last Landscapes : the Architecture of the Cemetery in the West. London: Reaktion, 2003.

Woudstra, Jan, and Colin Roth. A History of Groves. 1st ed. Milton: Routledge, 2018. 


\section{List of Figures}

Fig 1. Hollington, Sophy. 2020. Illustration For Dead Wood Essay. Image. Accessed November 8. https: / / emergencemagazine.org/story/dead-wood/.

Fig 2. Babyland. 2011. Image. https:/ / www.flickr.com/photos/ waltarrrrr/6190019935/.

Fig 3. US Cremation Equipment. 2020. Crematorium. Image. Accessed March 10. https: / / uscremationequipment.com/2018/03/05/burning-reallyhappens-inside-crematorium/.

Fig 4. Luciani, Domenico and Boschiero, Patrizia. Kongenshus Mindepark : The International Carlo Scarpa Prize for Gardens Treviso: Fondazione Benetton Studi Richerche, 2004.

Fig 5. Demokrasi için Medya. 2020. Pinara Necropolis. Image. Accessed March 12. http:// media4democracy.org/news/unesco-dnya-mirasinda-yer-
alan-pinara-ve-alinca.

Fig 6. Stucin, Sasa. 2016. Woodland Cemetery. Image. https:/ / purple.fr/ diary/the-woodland-cemetery-by-gunnar-ashland-and-sigurd-lewerentzstockholm/.

Fig 7. Pankhurst, Alvin. 2021. Guiding Spirits. Image. Accessed January 9. https:/ / pankhurst.co.nz/for-sale/.

Fig 8. Pankhurst, Alvin. 2021. Rising Spirits. Image. Accessed January 8. https:/ / pankhurst.co.nz/sold/.

Fig 9. Archives Online (10th Jul 2020). Bolton Street Cemetery Memorial Park Plan Three showing new position for proposed motorway, several features including Piazza concept [not adopted]. In Website Archives Online nodes/view/157223

Fig 9. Archives Online (10th Jul 2020). Bolton Street Cemetery Development Proposal Plan 1 showing proposed motorway and Piazza concept [not https:/ / archivesonline.wcc.govt.nz/nodes/view/157214

Fig 10. Luciani, Domenico and Boschiero, Patrizia. Kongenshus Mindepark : The International Carlo Scarpa Prize for Gardens Treviso: Fondazione Benetton Studi Richerche, 2004.

Fig 11. Constant, Caroline. The Woodland Cemetery : Toward a Spiritual Landscape : Eric Gunnar Asplund and Sigurd Lewerentz, 1915-61 Stockholm: Byggforlaget, 1994.

Fig 12. Stucin, Sasa. 2016. Woodland Cemetery. Image. https:/ / purple.fr / diary/the-woodland-cemetery-by-gunnar-ashland-and-sigurd-lewerentzstockholm/.

Fig 13. Oglander, Eric. 2020. Trees In Middle Village Cemetery. Image. https:/ / www.instagram.com/p/B_vuFfdlodV/.
Fig 14. Boffa Miskell. 1991. Wellington Town Belt Management Plan. Image. https:// www.boffamiskell.co.nz / project.php?v=wellington-town-belt-management-plan.

Fig 15. Potts, William. 1885. City Of Wellington. Image. https:/ / natlib.govt.nz/records $/ 23224811$ ?search $\% 5$ Bpath $\% 5 \mathrm{D}=$ items\&search $\% 5 \mathrm{Btext} \% 5 \mathrm{D}=$ William+potts.

Fig 16. Heaphy, Charles. 1841. Part Of Lambton Harbour, In Port Nicholson. Image. https: / / commons.wikimedia.org/wiki/File:Part_of_Lambton_Harbour__in_Port_Nicholson,_New_Zealand_1992-0035-768.jpg.

Fig 17. Davis, William Henry Whitmore. 1886. Photograph Of Lambton Quay. Image. https: / / natlib.govt.nz / records / 22734326? search\%5Bil\%5D\%5Bsubject\%5D=Lambton+Quay\&search $\% 5 \mathrm{Bil} \% 5 \mathrm{D} \% 5$ Byear $\% 5 \mathrm{D}=1866 \&$ search $\% 5 \mathrm{Bpath} \% 5 \mathrm{D}=$ photos\&search $\% 5$ Btext $\% 5 \mathrm{D}=$ Lambton+quay.

Fig 18. Alexander Turnbull Library. 1880. Premier House, Tinakori Road, Thorndon, Circa 1880. Image. https:/ / natlib.govt.nz/records/23254091?search\%5Bil\%5D\%5Bcategory $\% 5 \mathrm{D}=$ Images\&search $\% 5 \mathrm{~B}$ path $\% 5 \mathrm{D}=$ items\&search $\% 5 \mathrm{Btext} \% 5 \mathrm{D}=$ premier+house

Fig 19. Alexander Turnbull Library. 1894. View Over Thorndon From The Bolton Street Cemetery Looking Towards The Tinakori Hill.. Image. https:/ / natlib.govt.nz/records $/ 23248037$.

Fig 20. Vaniman, Melvin. 1902. Wellington From The Tinakori Hills. Image. https:// natlib.govt.nz / records $/ 23206476$ ?search $\% 5 \mathrm{Bil} \% 5 \mathrm{D} \% 5 \mathrm{Bcategory} \% 5 \mathrm{D}=$ =Images\&search $\% 5 \mathrm{~B}$ path $\% 5 \mathrm{D}=$ items\&search $\% 5 \mathrm{Btext} \% 5 \mathrm{D}=$ vaniman

Fig 21. Historic maps Sourced from http:/ / retrolens.nz and licensed by LINZ CC-BY

Fig 22. Campbell, Matthew. 2009. Archaeological Investigation Of 1-15 Pipitea Street, Wellington. Ebook. Auckland: CFG Heritage. https:/ / nzarchaeology.org/download/ archaeological-investigations-at-1-15-pipitea-street-wellington.

Fig 23. Roper-Lindsay, Judith. 1990. “Some Types of Trees in Pre European Flood Plai Forest (after Wassilieff 1990)." HRFCSR Environmental Investigations. Wellington, 39.

Fig 24. Telles, Gonçalo. 1966. Master Plan Of The Calouste Gulbenkian Park. Review Project, 1966. Image. https: / gulbenkian.pt/arquivo-digital-jardim/en/garden-document/ plano-geral-ampliacao/.

Fig 25. FCG - Serviço de Projectos e Obras. 1964. Santa Gertrudes Park: Completion Of Lake. Image. https:/ / gulbenkian.pt/arquivo-digital-jardim/en/garden-document/instalacoes-proprias-parque-de-santa-gertrudes-conclusao-dos-arranjos-exteriores-do-lago-2/

Fig 26. Balters, Sofia. 2011. View Over The Pond. Image. https:/ / www. archdaily.com/169378/ad-classics-calouste-gulbenkian-foundationuy-jervis-d\% 25e2\% 2580\% 2599athouguia-pedro-cid-and-alberto-pessoa/5107ddeb3rc4b27200013d-ad-classics-caloustegulbenkian-foundation-ruy-jervis-d\%25e2\%2580\%2599athouguia-pedro-cid-and-alberto-pessoa-image. 


\section{List of Figures}

Fig 27. Hisour. 2018. Calouste Gulbenkian Museum Lisboa Portugal. Image. https:/ / www.hisour.com/calouste-gulbenkian-museum-lisbonportugal-22183/

Fig 28. Museo Calouste Gulbenkian. 2009. Image. https:/ / commons. wikimedia.org/wiki/Category:Calouste_Gulbenkian_Museum\#/media/ File:Museo_Calouste_Gulbenkian.jpg.

Fig 29. Alexander Turnbull Library. 1893. Saunders Lane, Thorndon, Wellington, In Flood. Image. https: / / natlib.govt.nz/records/22651098.

Fig 30. Halse, Frederick James. 1893. Houses In Saunders Lane, In Thorndon, Wellington, Under Flood. Image. https:/ / natlib.govt.nz/ records $/ 23065560$ ?search $\% 5 \mathrm{Bi} \% 5 \mathrm{D} \% 5$ Bplace_authority_id $\% 5 \mathrm{D}=-$

321851\&search\%5Bpath\%5D=items.

Fig 31. Tupara, Hope. 2011. Wahakura. Image. https: / / teara.govt.nz/en/ video/27634/wahakura

Fig 32. Hats, Mrs Herk. 2019. Houhere Hat. Image. https:/ / www.instagram. com/p/B3DcM0aJntU/.

Fig 33. Te Papa Tongarewa. 2020. Hinaki (Eel/Fish Trap). Image. Accessed September 23. https:/ / collections.tepapa.govt.nz/ object/108380.

Fig 34. Te Papa Tongarewa. 2020. Para Kiekie (Kiekie Rain Cape). Image. Accessed May 10. https:/ / collections.tepapa.govt.nz/object/132288.

Fig 35. Rice, Pip. 2020. Muehlenbeckia Basket. Image. Accessed November 3. https:/ / www.woventales.co.uk/wpatwt/wp-content/gallery/baskets / piprice_wild-plane.jpg.

Fig 36. Samethangz Originalz. 2018. Whare Raupo. Image. https: / /www. acebook.com/ feelslikehomebro/ posts/whare-raupo-our-ancestors-oncelived-in-lets-bring-them-back-and-scatter-them-ac/1835975443198595/.

Fig 37. Te Papa Tongarewa. 2020. Ti Kouka Kete. Image. Accessed August 17 https:/ / collections.tepapa.govt.nz/object/ 60551 .

Fig 38. Te Papa Tongarewa. 2020. 'Matariki' Tukutuku Panel. Image. Accessed November 13. https: / / collections.tepapa.govt.nz / object/1361586.

Fig 39. Te Papa Tongarewa. 2020. Pātua (Bark Basket). Image. Accessed December 11. https:/ / collections.tepapa.govt.nz/object/131014.

Fig 40. Te Papa Tongarewa. 2020. Collospermum Hastatum (Colenso). Image. Accessed June 11. https:/ / collections.tepapa.govt.nz/ object/719054.

Fig 41. Te Papa Tongarewa. 2020. Potamopyrgus Oppidanus. Image. Accessed October 10. https:/ / collections.tepapa.govt.nz/object/ 642738. 